
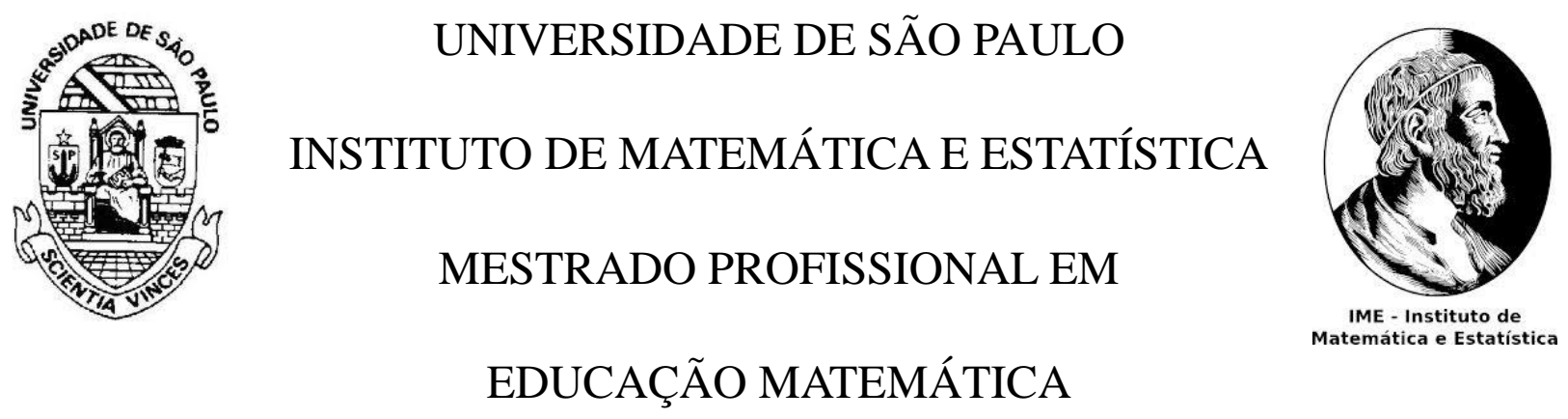

Entendendo alguns erros do Ensino Fundamental II que os alunos mantêm ao final do Ensino Médio

ANA LUIZA FESTA OZORES

SÃO PAULO

Abril/2016 



\author{
UNIVERSIDADE DE SÃO PAULO \\ INSTITUTO DE MATEMÁTICA E ESTATÍSTICA \\ MESTRADO PROFISSIONAL EM EDUCAÇÃO MATEMÁTICA
}

\title{
Entendendo alguns erros do Ensino Fundamental II \\ que os alunos mantêm ao final do Ensino Médio
}

\author{
Versão original da Dissertação apresentada ao Instituto de \\ Matemática e Estatística da Universidade de São Paulo \\ para a obtenção do título de Mestre em Educação Matemática.
}

ANA LUIZA FESTA OZORES

Orientadora:

Prof $^{\text {a }}$. Dr ${ }^{\text {a }}$. Bárbara Corominas Valério

SÃO PAULO

Abril/2016 

Dedico esta dissertação aos meus pais, Fernando e Maria Luiza, e à minha irmã, Ana Paula, por sempre estarem ao meu lado com palavras de amor, compreensão e apoio. Sem eles, essa conquista não seria possível. 



\section{AGRADECIMENTOS}

À Professora Doutora Barbara Valério, pela atenção e apoio durante o processo de orientação, contribuindo para meu crescimento científico e cultural.

Ao meu querido Diego Covales Bernardinelli, pelo afeto e carinho durante os momentos difíceis, sempre me incentivando a fazer um bom trabalho.

À Professora Adriane Covales e ao Professor Luiz Carlos de Faria, pela contribuição fundamental no processo de escolha dos alunos a serem estudados.

Ao Instituto de Matemática e Estatística, ao Instituto de Educação Beatíssima Virgem Maria, ao Colégio Vital Brazil e à Escola Estadual Ermano Marchetti, pela compreensão, disponibilização do espaço e acesso aos alunos.

Aos grandes amigos Livia Marchetti e Celso Cavicchia, pelo empenho e dedicação na revisão cuidadosa do texto.

Ao Instituto de Matemática e Estatística da Universidade de São Paulo, pela oportunidade de realização do curso de Mestrado. 



\section{RESUMO}

OZORES, Ana Luiza F. Entendendo alguns erros do Ensino Fundamental II que os alunos mantêm ao final do Ensino Médio. Dissertação de Mestrado para o Mestrado Profissional em Educação Matemática do Instituto de Matemática e Estatística da Universidade de São Paulo. São Paulo, 2015.

É natural considerar o erro como algo que deve ser evitado, um indicador de mau desempenho. Desde pequenas, as crianças são habituadas a buscar os acertos, de forma que, quando o raciocínio está errado, elas devem refazê-lo. Tal resultado é cobrado em casa pela família e na escola pelos educadores. Porém, o erro é o mais antigo elemento no processo de aprendizagem, e, além de ser um indicador de desempenho, o erro também mostra aquilo que o aluno sabe ou pensa ter compreendido.

É possível notar que alguns alunos do Ensino Médio mantêm erros e dúvidas que deveriam ter sido sanados ao longo do Ensino Fundamental. Neste trabalho, será analisado o porquê de essas dúvidas ainda se apresentarem, pois a análise desses erros pode auxiliar tanto o aluno como o professor. O aluno, com uma devolutiva do que foi feito para tentar aprimorar o seu saber e o professor, levando-o a elaborar novas estratégias didáticas e planos de ensino que melhor se adaptem ao seu público alvo.

\section{Palavras-chave}

Erro. Análise de erro. Avaliação. 



\begin{abstract}
OZORES, Ana Luiza F. Understanding some mistakes from Secondary School that students hold until the end of High School. Dissertação de Mestrado para o Mestrado Profissional em Educação Matemática do Instituto de Matemática e Estatística da Universidade de São Paulo. São Paulo, 2015.
\end{abstract}

It is expected to consider the error as something that must be avoided, a non-satisfactory performance indicator. Since childhood, the human being is used to seek the right answers, so that, when the reasoning is wrong, he/she should remake it. Such outcome is charged at home by the family and at school by the teachers. However, the error is the oldest element in the learning process and, in addition to being a performance indicator, the error also shows something that the student knows or thinks he/she has understood.

It is possible to notice that some high school students make some mistakes or has some doubts that were supposed to be clarified during the elementary school. In this paper, it will be analyzed the reason why these doubts are still present, because the analysis of these errors can help both students and teachers. The students, with a feedback of what has been done to try to improve their knowledge and the teacher, leading him to design new teaching strategies and lesson plans to best suit his/her target audience.

\title{
Keywords
}

Error. Error analysis. Evaluation. 



\section{SUMÁRIO}

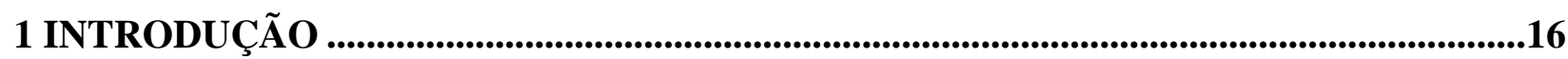

2 REFERENCIAL TEÓRICO .....................................................................................................................21

2.1 O CONCEITO DE ERRO ...................................................................................................................21

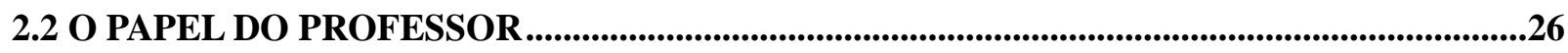

2.3 EFEITO TOPÁZIO, CONTRATO DIDÁTICO E TRANSPOSIÇÃO DIDÁTICA...................29

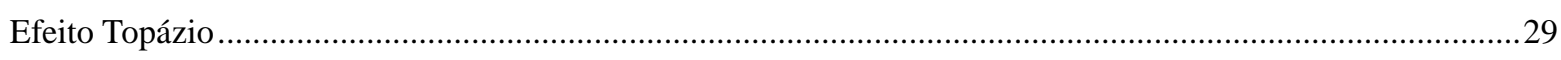

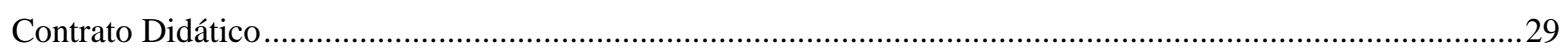

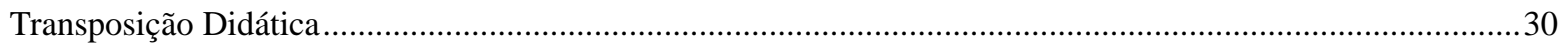

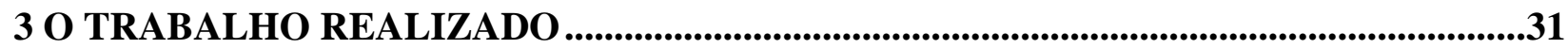

4 PRIMEIRO QUESTIONÁRIO..........................................................................................32

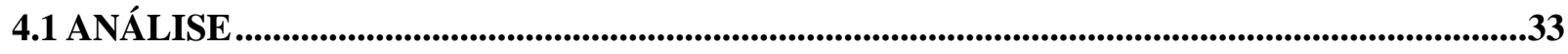

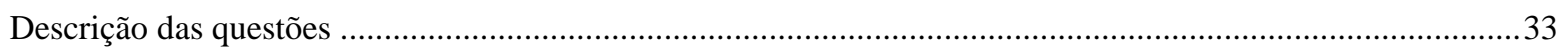

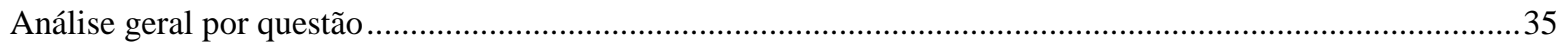

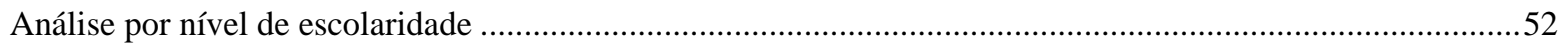

4.2 CONCLUSÕES PARCIAIS .........................................................................................................................55

5 SEGUNDO QUESTIONÁRIO...................................................................................56

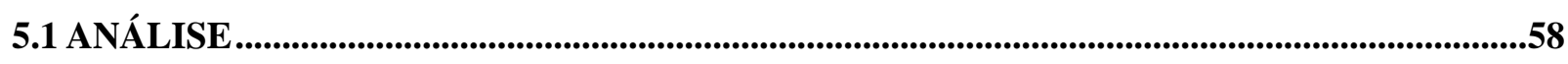

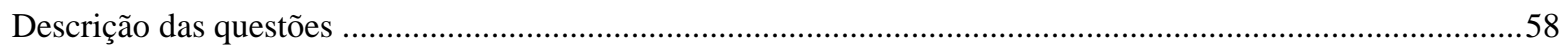

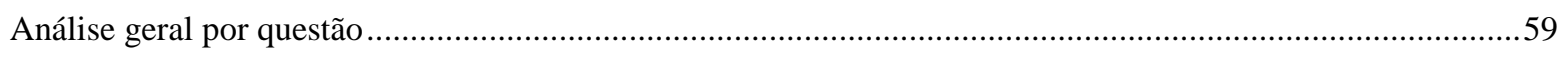

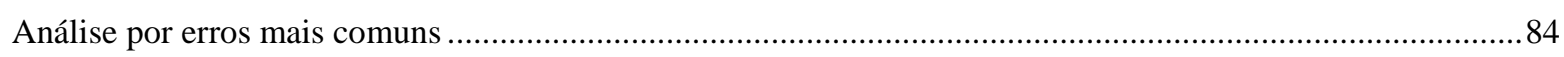

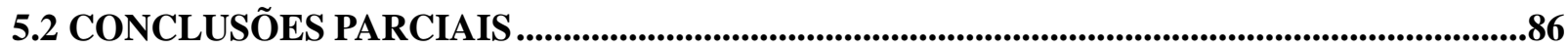

6 ENTREVISTAS …..............................................................................................................................................87

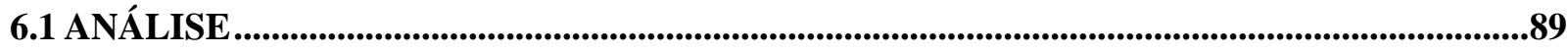

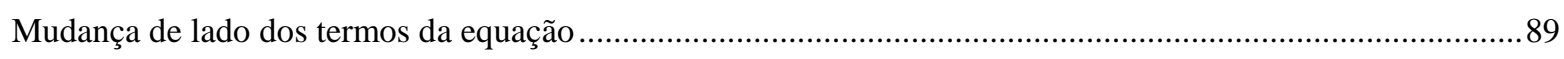

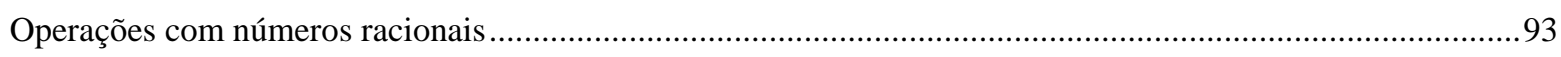

Operações com termos da expressão polinomial .........................................................................................96

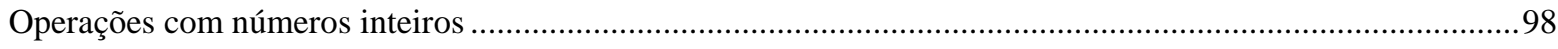

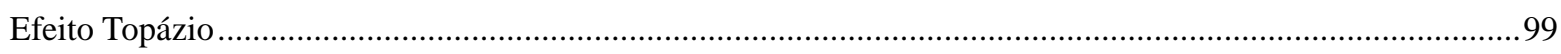




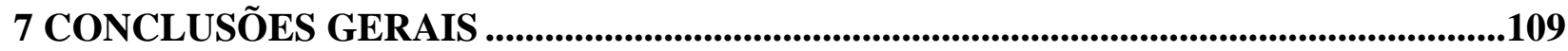

8 REFERÊNCIAS BIBLIOGRÁFICAS ..............................................................................112

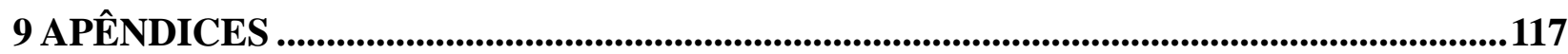

9.1 PRIMEIRO QUESTIONÁRIO ................................................................................................................117

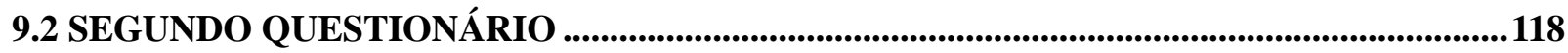

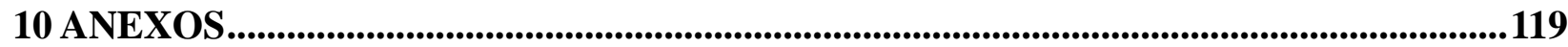

10.1 QUESTIONÁRIOS DOS ALUNOS ENTREVISTADOS ..............................................119

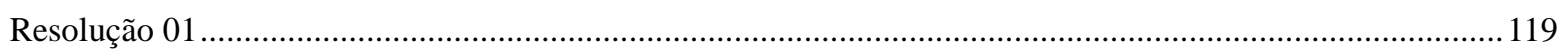

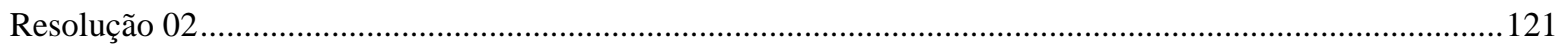

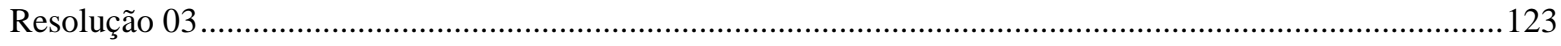

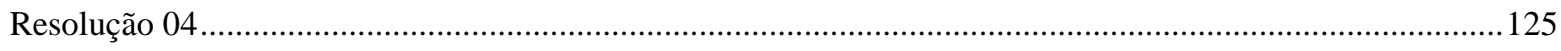

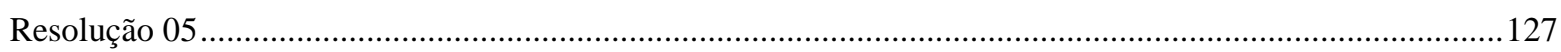

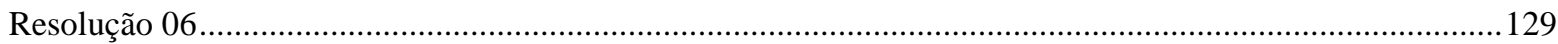

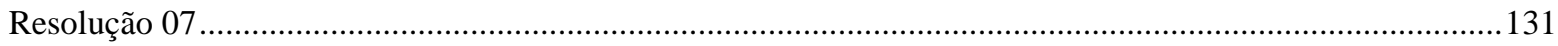

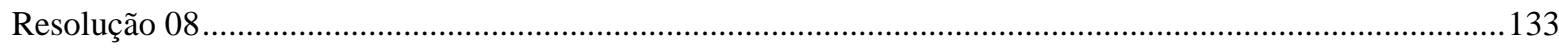

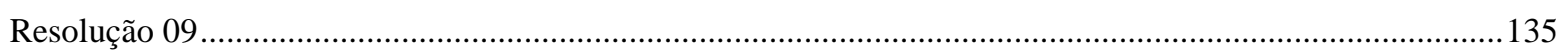

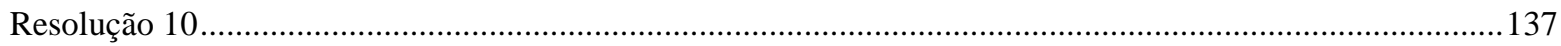

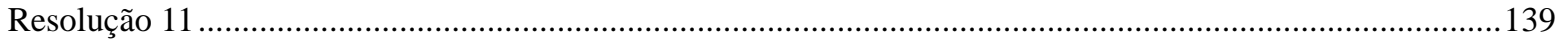

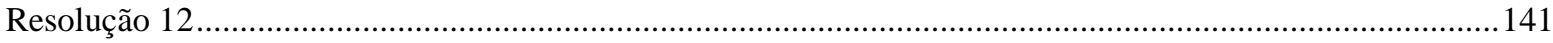

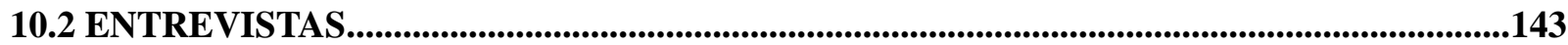

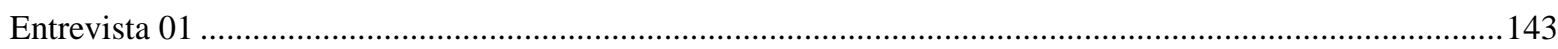

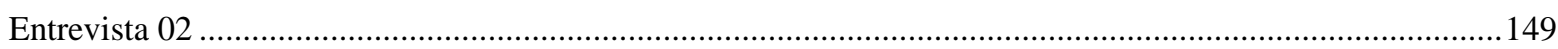

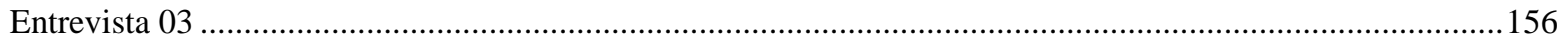

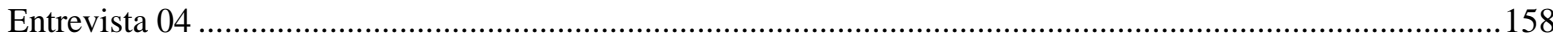

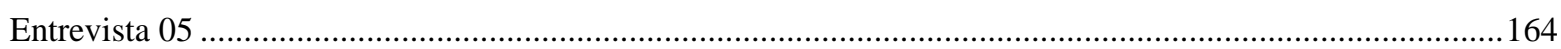

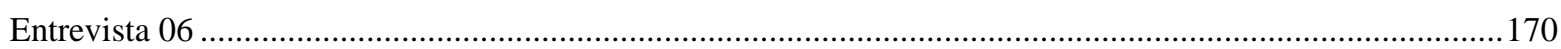

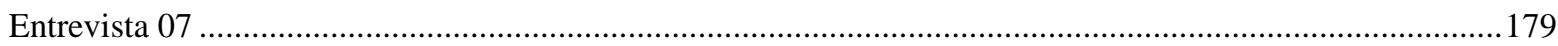

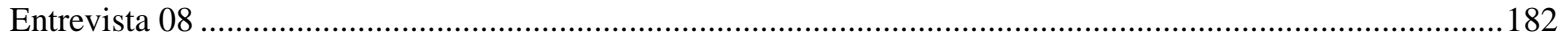

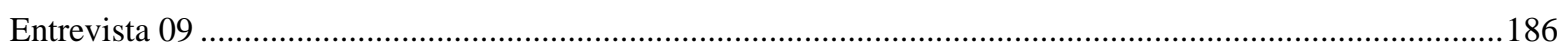

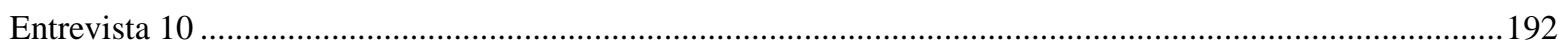




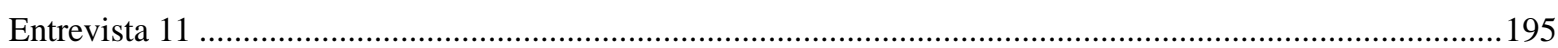

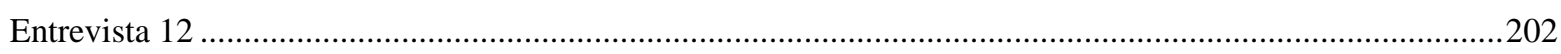




\section{INTRODUÇÃO}

Como o conteúdo da Matemática é cumulativo, é necessário o entendimento do assunto anterior para que o avanço seja significativo, construindo o conhecimento matemático do aluno. Caso contrário, a defasagem se torna cada vez maior e a chance de o aluno compreender os novos conceitos que lhe são apresentados fica cada vez mais remota. Ou seja, a dificuldade que o aluno apresenta em um conteúdo do Ensino Fundamental, se não sanada e compreendida, acarretará um provável bloqueio e uma alienação do aluno para um novo tema visto no Ensino Médio. Isso fica claro quando o professor ouve frases do tipo: “eu não sei isso", "eu sou burro", "a Matemática é impossível", "nunca me ensinaram isso", "pra que eu preciso aprender isto?” etc. quando o aluno tenta mascarar a dificuldade que possui, originada por dúvidas não esclarecidas anteriormente.

O resultado do PISA $^{1}$ de 2012 sugere que 67,1\% dos alunos brasileiros têm um desempenho baixo em Matemática, o que significa que, no máximo, eles conseguem extrair informações relevantes de um simples enunciado e usar algoritmos básicos, fórmulas, procedimentos ou convenções para resolver problemas envolvendo números. Além disso, apenas $1,1 \%$ dos nossos estudantes têm um bom desempenho em Matemática, o que significa que poucos conseguem desenvolver e trabalhar com modelos de situações complexas, elaborar estratégias, desenvolver o pensamento e as habilidades de raciocínio. Esses dados indicam que realmente existe um problema no processo de ensino e aprendizagem da Matemática no Ensino Fundamental brasileiro, o que pode gerar, dentre outras coisas, a falta de domínio dos conceitos básicos citados anteriormente.

Reforçando essa ideia, o Relatório Pedagógico do SARESP ${ }^{2}$ de 2013 indica que mais de $54 \%$ dos alunos do $3^{\circ}$ ano do Ensino Médio da Rede Pública do Estado de São Paulo apresentam nível de proficiência insuficiente em Matemática. Já no relatório de 2011, encontramos

\footnotetext{
${ }^{1}$ De acordo com o site do Inep, o Programa Internacional de Avaliação de Estudantes (PISA - Programme for International Student Assessment) é uma avaliação internacional, aplicada a estudantes na faixa dos 15 anos, idade em que se pressupõe o término da escolaridade básica obrigatória na maioria dos países. O objetivo do Pisa é produzir indicadores que contribuam para a discussão da qualidade da educação nos países participantes. Essas avaliações acontecem a cada três anos e abrangem três áreas do conhecimento - Leitura, Matemática e Ciências havendo, a cada edição do programa, maior ênfase em cada uma dessas áreas.

${ }^{2}$ O SARESP, Sistema de Avaliação de Rendimento Escolar do Estado de São Paulo, é uma prova aplicada anualmente desde 1996 nas escolas públicas para avaliar o ensino básico. Além de ser um dos indicadores que compõe o Índice de Desenvolvimento da Educação do Estado de São Paulo, o IDESP, mais do que avaliar escolas, o SARESP ajuda a monitorar e a traçar planos para o ensino das escolas públicas paulistas.
} 
$\mathrm{Na} 3^{\mathrm{a}}$ série do Ensino Médio cresce o percentual dos alunos no nível Abaixo do Básico nas três edições $(2009,2010,2011)$ : é quase $60 \%$ de alunos situados nesse nível, o que significa que esses alunos demonstram domínio insuficiente dos conteúdos, competências e habilidades em Matemática, esperadas para o final do Ensino Médio. [...] É inevitável a pergunta: será que os alunos estão carregando suas dificuldades em Matemática para as séries subsequentes? $\mathrm{Na}$ análise pedagógica dos resultados do SARESP 2011 haverá muitas situações em que a resposta afirmativa a essa questão é inevitável. (Relatório Pedagógico SARESP, 2011)

Como professora do Ensino Médio, pude notar que muitos alunos apresentam questionamentos matemáticos básicos como regra de sinais, contas com fração, ordem das operações, entre outros. Tais dúvidas já deveriam ter sido eliminadas ao longo do Ensino Fundamental ou mesmo durante o Ensino Médio, mas é possível identificar muitos alunos que concluem o Ensino Básico com uma "bagagem mal resolvida". Conversando com outros professores de Ensino Médio e até mesmo de Ensino Superior, percebi que esse é um problema recorrente e não apenas uma percepção individual.

A Matemática é o contato mais direto que o aluno tem com o raciocínio lógico, talvez até um dos primeiros. Dessa forma, o desenvolvimento matemático estimula habilidades que auxiliam outras áreas do conhecimento. Sendo assim, uma defasagem em Matemática, além de gerar dificuldades na compreensão da própria disciplina, pode gerar problemas em outras áreas, como Física, Química e até mesmo Biologia e Geografia, pois nessas áreas os cálculos desenvolvidos na Matemática são utilizados como ferramenta básica.

Nas palavras de Mônica G. P. Bardichi (2013), professora da Escola Estadual Professor Isaltino de Mello, bolsista supervisora no PIBID ${ }^{3}$ :

Os professores ressaltaram que muitos alunos chegam ao Ensino Médio com grandes dificuldades em aspectos básicos da Matemática, como operações com números inteiros, fracionários, expressões algébricas, equações e na interpretação de problemas. Esta falta de base, queixa recorrente dos professores de Matemática, Química e Física, contribui para que muitos alunos tenham dificuldades no aprendizado dessas disciplinas.

Essas dificuldades fazem com que o aluno se torne alheio à aula. Alguns autores como

\footnotetext{
${ }^{3}$ De acordo com o site da CAPES, o PIBID, Programa Institucional de Bolsa de Iniciação à Docência, é uma iniciativa para o aperfeiçoamento e a valorização da formação de professores para a educação básica. $\mathrm{O}$ programa concede bolsas a alunos de licenciatura em parceria com escolas de educação básica da rede pública de ensino. Os projetos devem promover a inserção dos estudantes no contexto das escolas públicas desde o início da sua formação acadêmica para que desenvolvam atividades didático-pedagógicas sob orientações de um docente da licenciatura e de um professor da escola.
} 
Cury (2013), Santos (2014) e Borasi (1996) mencionam que um dos motivos do fracasso escolar seria que os alunos acabam decorando regras para as avaliações sem entender os seus reais significados, porém, quando não são mais cobrados e esse conhecimento não se faz mais necessário, tudo é apagado de suas memórias.

Acredito que os alunos que possuem um melhor rendimento e aproveitamento no Ensino Médio sejam exatamente aqueles alunos que tiveram uma aprendizagem significativa durante o Ensino Fundamental, isto é, os conteúdos ensinados a esses alunos de fato foram assimilados, sem que houvesse a necessidade de memorização de regras e fórmulas. Nas palavras de Santos (2014),

A formação matemática necessária ao aluno do nível fundamental é parte importante do processo de formação geral a ser promovido pela escola por meio de variadas atividades e práticas pedagógicas relacionadas com as diferentes áreas do conhecimento. Em linhas gerais, tal formação objetiva a aquisição e construção, pelo aluno, de ferramentas conceituais e instrumentais imprescindíveis ao exercício da cidadania, ao pertencimento e intervenção na sociedade e cultura de que faz parte; à construção de trajetórias e projetos individuais e/ou coletivos, às tomadas de decisões que tudo isso implica etc. (SANTOS, 2014, p.43)

Penso também que um dos motivos das dúvidas dos alunos possam ser alguns "maus hábitos" que os professores passam aos alunos ou a técnica de decorar alguns algoritmos sem saber o seu real motivo e significado. Dessa forma, o aluno apenas reproduz aquilo que o professor faz em sala, sem de fato ter compreendido tal conteúdo. Algumas perguntas se tornam frequentes como “cai na prova?” ou "vale nota?". O foco do aluno deixa de ser o conteúdo em si e passa a ser apenas a nota, assimilando somente o necessário para que possa ter um bom desempenho na avaliação.

Essa memorização equivocada, a falta de compreensão de alguns conteúdos e a preocupação apenas focada na avaliação podem fazer com que os alunos apresentem resultados que não correspondem ao esperado, constituindo alguns erros. Para Vinner, Hershkowitz e Bruckheimer (1981), os procedimentos errados das crianças são, muitas vezes, regras corretas mal aplicadas ou distorcidas. E os erros resultam da organização dessas estratégias e regras.

Segundo Cury (2013), o papel do erro no processo de ensino-aprendizagem depende de como ele ocorre na resolução das tarefas. O aluno pode errar por descuido, quando seria necessário apenas refazer o processo. Pode errar por conta de uma estrutura de pensamento 
insuficiente para selecionar uma estratégia eficiente de resolução, em vez de, com o auxílio do professor, tentar construir um novo conhecimento com base em seu erro. Trata-se, portanto, de um "erro construtivo". Existe também o caso em que o aluno sequer compreende o que lhe foi solicitado, mas sente a necessidade de apresentar algum resultado. Nesse caso acontecem os “erros sistemáticos”, nos quais o aluno reproduz algum processo já visto anteriormente.

Em sua pesquisa, Radatz (1979) classificou os erros encontrados e concluiu que

Em primeiro lugar, erros na aprendizagem da Matemática não são simplesmente a ausência de respostas corretas ou o resultado de acidentes infelizes. Eles são consequência de processos definidos, cuja natureza deve ser descoberta. Em segundo lugar, parece ser possível analisar a natureza e as causas subjacentes de erros em termos do mecanismo de processamento de informações do indivíduo. Em terceiro lugar, a análise de erros oferece uma variedade de pontos de partida para a investigação sobre os processos por que as crianças aprendem Matemática. E em quarto lugar, a prevalecência quantitativa de testes e métodos similares para medir a realização não pode prover critérios suficientes para procedimentos eficientes de ensino. Considerar esse diagnóstico e as possíveis causas dos erros poderia dar uma ajuda específica para os professores de Matemática, permitindo-lhes integrar os seus conhecimentos sobre o conteúdo curricular com o seu conhecimento sobre as diferenças individuais das crianças. (RADATZ, 1979, p. 170, tradução nossa)

Sendo assim, a análise de erros é fundamental no processo de ensino-aprendizagem. Quando feita pelo aluno, como uma devolutiva do que foi apresentado, ele pode compreender seu próprio erro, entender seu raciocínio e buscar corrigi-lo com o auxílio de colegas, do professor ou de livros didáticos. Quando feita pelo professor, essa análise ajuda a traçar um perfil da sala de aula em que está trabalhando, além de se tornar um ingrediente fundamental para criar um novo ambiente de ensino e planejar novas estratégias.

Para tentar compreender o raciocínio dos alunos, pretendo analisar alguns erros cometidos em determinadas resoluções, de forma a mapear as dúvidas e suas origens. Cury (2010) considera que, para Borasi

Há três objetivos para o uso dos erros: remediação, descoberta ou pesquisa. Com certeza, o que atrai de imediato a atenção dos professores, preocupados com as dificuldades apresentadas pelos alunos, é a remediação. Detectado um erro, procura-se reapresentar o conteúdo, com a (falsa) crença de que a repetição vai fazer com que a falta de compreensão sobre o tópico em questão vai fazer com que o aluno entenda e não cometa mais o mesmo erro. No entanto, se essa ideia fosse correta, não teríamos os erros sistemáticos, pois detectados e remediados por uma nova explicação, já teriam sido eliminados. Assim, é necessário encontrar outras maneiras de chegar às possíveis causas de um determinado erro e discuti-las com os professores, em especial. (CURY, 2010, pg. 08) 
A partir de observações feitas no meu dia a dia e algumas pesquisas de campo estudadas, pretendo verificar se os alunos do Ensino Médio têm muita dificuldade com situações "clássicas", como operações com frações, regras de sinais, potenciação etc., presentes nos conteúdos do Ensino Fundamental II e se, de fato, eles decoram fórmulas e algoritmos sem entender o real motivo e significado de suas utilizações, muitas vezes reproduzindo o que foi feito pelo professor ou generalizando erradamente, em uma nova situação, um processo já visto.

Diante disso, em minha dissertação pretendo identificar algumas dificuldades básicas e, a partir da análise dos erros cometidos no processo, tentar compreender o porquê de elas ainda se apresentarem ao final do Ensino Médio. Os dados analisados para o desenvolvimento deste trabalho foram obtidos por meio de questionários e entrevistas realizadas principalmente com alunos do $3^{\circ}$ ano do Ensino Médio.

Os conteúdos que foram escolhidos para serem abordados foram de origem aritmética e algébrica, tratando-se de uma parte da Matemática facilmente contextualizável na vida do aluno. Porém, vale destacar que foi visto o conteúdo em si, descontextualizado, pois se visa entender a dificuldade matemática dos alunos com os conceitos básicos. Não serão trabalhadas, portanto, algumas dificuldades que os alunos também apresentam como a interpretação de enunciados de questões e a compreensão de situações problema. 


\section{REFERENCIAL TEÓRICO}

\subsection{O CONCEITO DE ERRO}

É natural considerar o erro como algo que deve ser evitado, um indicador de mau desempenho. Desde pequenas, as crianças são habituadas a buscar os acertos, de forma que, quando o raciocínio está errado, elas devem refazê-lo. Tal resultado é cobrado em casa pela família e na escola pelos educadores. Com o passar do tempo, a repreensão do raciocínio não esperado acaba podando modos diferentes de pensar e, em especial na escola, os alunos vão se acostumando a não fazer mais comentários em aula, pois, se o que for dito estiver errado, não será aceito. Esse é um conceito muito comum: quando o aluno sabe, ele acerta e, quando não sabe, ele erra.

Pelo que se conhece da história, grandes mentes que passaram pela humanidade realizaram diversos feitos devidos aos seus erros. Todos eles fizeram várias tentativas antes de chegar ao resultado esperado e desejado. Nossos alunos estão se deparando com grandes conteúdos pela primeira vez. Conteúdos esses que provavelmente levaram anos para ser entendidos por pesquisadores. Por que, então, alguns professores insistem em considerar o erro como um indicador de que o aluno não entendeu o que lhe foi passado? Será que o erro demonstra somente aquilo que o aluno não sabe?

Freitas (2002) afirma que, para Brousseau, os erros não são simples ausência de conhecimento, mas expressam conhecimentos mal formados que depois se tornam resistentes. Pinto (2000) reforça que, para Brousseau, o erro é resultado de um conhecimento anterior que teve seu interesse e seu sucesso, mas que agora se revela falso, conceito esse também mencionado em Oliveira, Arruda, Silva e Camargo (2012). Sendo assim,

\footnotetext{
é necessário romper com o conhecimento anterior para predominar um novo conhecimento e este conhecimento anterior, que tinha a sua importância, pode se manifestar por meio de erros, [...] mas estes erros não são devidos ao acaso, fugazes, erráticos, eles são reprodutíveis, persistentes. (BARROSO e FRANCO, 2013, p. 07)
}

Os obstáculos epistemológicos de Bachelard são citados por Brousseau (2008) como um conhecimento que dá resultados corretos em um determinado contexto, mas manifesta-se falso ou inadequado em um contexto novo ou mais amplo. Tais obstáculos se manifestam através dos erros e 
[...] não desaparecem com a aprendizagem de um novo conhecimento. Pelo contrário, opõe resistência à sua aquisição, à sua compreensão, retarda a sua aplicação, subsiste em estado latente e reaparece de súbito, em especial no contexto anterior, quando as circunstâncias o permitem. Portanto, é inútil ignorar um obstáculo. Deve-se rechaçá-lo de maneira explícita, integrar sua negação à aprendizagem de um conhecimento novo, em particular na forma de contraexemplos. Nesse sentido, é um constitutivo do saber. (BROUSSEAU, 2008, p. 50)

Brousseau (2008) caracteriza obstáculo epistemológico como um conhecimento utilizado pelo indivíduo para produzir respostas que se adaptam a certo contex to que o aluno encontra com frequência, mas que usado fora desse contexto gera respostas incorretas. "Trata-se da resistência oferecida por conceitos considerados verdadeiros, em um determinado período, e que, na realidade, dificultam a formação de um novo saber” (PAIS, 2001, p. 113). Já a percepção de uma contradição está vinculada ao nível de conhecimento do sujeito, por isso é importante

[...] aprender a valorizar o raciocínio lógico e argumentativo torna-se um dos objetivos da educação matemática, ou seja, despertar no aluno o hábito de fazer uso de seu raciocínio e de cultivar o gosto pela resolução de problemas. (PAIS, 2001, p. 35)

Segundo Oliveira, Arruda, Silva e Camargo (2012), um obstáculo é um conhecimento que pode ser dividido em epistemológico, didático, psicológico ou ontogênico. Um obstáculo epistemológico é referente à construção do conhecimento ao longo da história. Já o didático surge a partir das escolhas das estratégias de ensino do professor. O psicológico aparece quando o conteúdo ensinado entra em contradição com a vida. E o ontogênico está relacionado às limitações neurofisiológicas do sujeito. Cury e Konzen (2007) interpretam os obstáculos como uma espécie de vícios que, embora errados, funcionam em alguns casos específicos. E Pinto (2000) também os define como uma resistência de um saber mal adaptado.

Para Pinto (2000), o erro é o mais antigo elemento no processo de ensino, está ligado ao processo avaliativo e é visto como um indicador de progresso. O erro é considerado algo que não deveria ter ocorrido, sempre associado ao castigo e ao fracasso, pois, no sistema usual de avaliações o professor aponta sempre as falhas cometidas e a prática corretiva faz o aluno dar por corrigidos erros que não foram compreendidos. Sendo assim, o erro é anulado e corrigido imediatamente, pois aqueles que o cometem são considerados fracos. Mas o erro não é somente resultado da ignorância; reconhecendo o conhecimento em construção, o erro se torna parte integrante do processo de aprendizagem e "o ato de explicar e dar sentido aos seus próprios erros 
é uma atividade altamente estimuladora e provocativa para os alunos" (PINTO, 2000, p. 37), enfatizando a necessidade da análise de erros. Para ela, o erro possui duas faces: a positiva, que auxilia na construção do conhecimento e a negativa, quando ele serve como punição para um raciocínio não esperado. O Construtivismo de Piaget, citado por ela, acredita que o erro deve perder sua conotação negativa, passando a ser essência da pedagogia do sucesso e não do fracasso.

Pinto (2000) cita a assimilação e a acomodação do Construtivismo. A assimilação é o processo cognitivo pelo qual uma pessoa integra um novo dado às suas estruturas cognitivas prévias, já a acomodação é toda modificação nos esquemas dessas estruturas. $\mathrm{O}$ constante equilíbrio entre assimilação e acomodação é chamado de adaptação. Em outras palavras, a construção do conhecimento ocorre quando acontecem ações que provocam o desequilíbrio, resultando em assimilação ou acomodação. Uma vez que a criança não consiga assimilar o estímulo, ela tenta fazer uma acomodação seguida de uma assimilação, alcançando, assim, um equilíbrio. Existem algumas perturbações que se opõem à acomodação, resultando em insucessos ou erros, porém tais erros são vistos sempre como construtivos, fazendo parte do processo de aprendizagem.

No processo de construção das estruturas lógicas, os erros, segundo Piaget (1976), são produzidos como resultado dos conflitos cognitivos que os sujeitos vivem no esforço para se adaptarem a novas situações. Conflito cognitivo para Piaget é o termo usado para explicar o processo através do qual ocorrem mudanças cognitivas, ou seja, passagem de um estado de equilíbrio a outro, (teoria da equilibração), através de um período de transição em que há formas contraditórias de interpretar e resolver um mesmo problema. O conflito se supera quando, por um processo de regulação interna, há uma reorganização e coordenação das ações em jogo. (TEIXEIRA, 1997, p. 49)

Cury (1994) fez diversas pesquisas sobre o papel dos erros no processo de ensino. Ela diz que o erro não é somente efeito da ignorância, da incerteza e do acaso; os erros são esperados e ajudam a detectar maneiras de como o aluno pensa. Ela propõe que se entenda o erro como o que não corresponde à produção esperada de um aluno.

Os erros cometidos pelos alunos são considerados estágios necessários à exploração de problemas e podem ser utilizados, pelo professor ou pelos próprios alunos, para novas descobertas e para discussão dos conceitos envolvidos em um determinado problema matemático. (CURY, 1994, p. 132) 
Se a avaliação e a perspectiva de ensino fossem centradas no processo ao invés de somente no resultado, aceitando a possibilidade de refutar e corrigir os conceitos matemáticos, seria possível partir dos erros para explorar a Matemática. Sendo assim, os erros deixariam de ser frustrantes e passariam a ser fonte de nova aprendizagem, desenvolvendo a capacidade crítica dos alunos.

Quando o erro é usado como fonte de novas descobertas, está sendo considerada a possibilidade de que este erro se transforme em um problema para que os alunos (e o professor) se debrucem sobre ele e tentem inventar soluções que promovam o aprendizado. [...] o erro se constitui como um conhecimento, é um saber que o aluno possui, construído de alguma forma, e é necessário elaborar intervenções didáticas que desestabilizem as certezas, levando o estudante a um questionamento sobre suas respostas. (CURY, 2013, p. 81 e 82)

Dessa forma se torna indispensável fazer uma análise dos erros com os alunos. Aquela antiga correção de erros interminável e repetitiva não é mais eficaz, a análise dos erros deve ser vista como "uma abordagem de pesquisa e uma metodologia de ensino" (id., p.93). Discutir os erros não é uma tarefa fácil já que os alunos temem a reação do professor por não conseguirem dar a resposta esperada, mas o erro é a fonte dos saberes e assim se torna um subsídio para novos métodos de ensino e novas avaliações.

Em Sperafico e Golbert (2012) são citados os PCN (Parâmetros Curriculares Nacionais) de 1998, que afirmam que a importância da resposta certa cedia lugar à importância do processo de solução. Essa ideia reforça a necessidade de uma análise dos erros, até mesmo como método de avaliação para os professores. Cury (2013) afirma que, para Piaget, um erro corrigido pelo próprio aluno pode ser mais fecundo que um acerto imediato, porque a comparação de uma hipótese falsa e suas consequências fornece novos conhecimentos e a comparação entre dois erros dá novas ideias.

Para Moraes (2013), o erro é um conhecimento, é um saber que o aluno possui e não a falta dele. Ele não considera que os erros demonstram aquilo que os alunos não sabem, assim como não é possível assumir que os acertos demonstram aquilo que eles sabem. Os alunos podem acertar um exercício por inúmeras razões sem ter, de fato, absorvido o conteúdo em questão. O autor considera o erro como um processo natural na construção do conhecimento.

Para Santos (2014), esses erros podem ser gerados devido à falta de comunicação entre os ciclos de ensino (Ensino Fundamental I, Ensino Fundamental II e Ensino Médio), gerando uma 
dificuldade em Matemática. Muitas vezes os professores ensinam duas vezes o mesmo assunto de maneiras diferentes ou acabam deixando de tratar algum conteúdo. Essas lacunas acabam gerando problemas de aprendizagem para os alunos, o que pode levar a alguns erros. Outro motivo para o aparecimento de erros, citado por Santos, é a falta de contextualização. Como já existe um pré-conceito de que Matemática é difícil, os alunos acabam manipulando técnicas e símbolos sem entender suas regras e lógicas. Dessa forma, muitas vezes existe um desencontro entre a expectativa do aluno e a realidade, gerando o chamado fracasso e levando o aluno ao abandono do problema. Se o aluno passasse a ver o erro como parte integrante da resolução, seria habitual ter momentos de insatisfação e talvez ele não desistisse tão fácil do seu raciocínio. 


\subsection{O PAPEL DO PROFESSOR}

É possível notar como a compreensão da Matemática prévia é importante para o aluno conseguir entender novos tópicos. Tal compreensão é facilitada quando o conteúdo adquire significado, ou seja, quando o aluno enxerga relações do conteúdo com o seu cotidiano; caso contrário, o que ele vê em aula serve apenas para uso em avaliações da escola. Segundo pesquisas feitas por Ávila e Santiago (2012), alguns alunos estão finalizando o Ensino Fundamental e iniciando o Ensino Médio sem sequer ter construído os conceitos das quatro operações. Para eles, os assuntos mais elaborados que serão vistos nos três anos seguintes serão de muito difícil aprendizagem.

$\mathrm{O}$ professor, então, tem um papel fundamental como mediador entre o aluno e o conhecimento. Ele é responsável por desconstruir mitos e crenças, dar significado ao novo conteúdo a fim de torná-lo compreensível, além de promover e manter o interesse dos diversos grupos aos quais leciona. Para isso, é necessário contextualizar e personalizar o conhecimento, pois a construção não se dá apenas pela transposição do professor. Nas palavras de Barufi (1999),

(...) o professor de Matemática executa uma tarefa muito diferente, na medida em que ele precisa recontextualizar e repersonalizar o conhecimento que seus alunos necessitam articular, isto é, realiza um processo que é contrário, em certo sentido, ao dos matemáticos que produziram o conhecimento. (BARUFI, 1999, p.30)

Sendo assim, uma das tarefas do professor é contextualizar um assunto que se apresenta fora de contexto de forma totalmente impessoal, pois o aluno precisa ver a necessidade de se aprender o que lhe está sendo apresentado; afinal, "a construção do conhecimento por parte dos alunos não ocorre por simples transposição, através da exposição por parte do professor, de seu próprio conhecimento estruturado e articulado". (id., p.33)

É importante pontuar que os alunos chegam à escola com um conhecimento prévio. Esse conhecimento pode gerar alguns obstáculos, cabendo ao professor fazer o intermédio entre o que o aluno já sabe, ou pensa que sabe, e o que irá aprender.

Os professores de ciências imaginam que o espírito começa como uma aula, que é sempre possível reconstruir uma cultura falha pela repetição da lição, que se pode fazer entender uma demonstração repetindo-a ponto por ponto. Não levam em conta que o adolescente entra na aula de física com conhecimentos empíricos já construídos: não se trata, portanto, de adquirir uma cultura experimental, mas sim de mudar de cultura experimental, de derrubar obstáculos já sedimentados pela vida cotidiana. (Bachelard apud BARROSO e FRANCO, 2013, p. 06) 
Oliveira, Arruda, Silva e Camargo (2012) afirmam que não é fácil estabelecer estratégias sem descaracterizar a essência do conteúdo matemático; porém não é impossível e cabe ao professor tornar a aula mais atraente. Santos (2014) ainda coloca que, muitas vezes, a formação do professor não é específica, gerando um baixo aproveitamento da aula por parte dos alunos, devido à falta de preparo do professor. Acredito que tal situação aconteça com mais frequência no Ensino Fundamental I, quando os professores são polivalentes, não havendo a necessidade da formação específica. Por ser justamente nessa fase que alguns conceitos básicos, como as quatro operações, são apresentados, seria importante que os professores tivessem total domínio sobre o tema.

Quando a resolução dos alunos não é a esperado pelo professor, este costuma fazer uso da "Síndrome da tinta vermelha", sugerida por Astolfi conforme citado em Pinto (2005), em que há ênfase nas falhas, sempre apontando os erros. Porém, cada aluno tem um jeito próprio de resolver um problema, e cabe ao professor entender as diferentes maneiras de trilhar o caminho até a resposta, estando ela correta ou não. Quando as soluções divergem, o professor deve identificar o erro, perceber a incidência e planejar situações para provocar sua superação. Em outras palavras, é necessário que o erro do aluno gere um desafio para o professor.

Segundo Cury (1994), os erros cometidos pelos alunos são considerados falhas no processo de aprendizagem, e a preocupação do professor é a de retomar os conteúdos, mostrando a resolução considerada correta, para que o aluno não cometa os mesmos erros. O professor desenvolve, então, um gabarito para as provas, pressupondo que existe apenas uma maneira correta de se proceder em cada questão. O objetivo, nesse caso, é a eliminação do erro.

Com relação à análise de erros, Cury (2009) afirma que os professores enfrentam dois problemas: os alunos procuram empregar cálculos como comprovação dos resultados em vez de questionar sua existência, e muitas vezes falham em alguns conceitos fundamentais da álgebra ou da análise. Seria interessante que o professor confrontasse o erro do aluno com as perguntas "o que aconteceria se aceitássemos esse resultado?" ou "em que circunstância esse resultado pode ser considerado correto?".

Uma prática válida para auxiliar no processo de ensino-aprendizagem é o diálogo entre o professor e o aluno (RAMOS, 2014, p. 69 e 72), pois, muitas vezes, o aluno não sabe qual foi o 
seu erro e o motivo. Assim, o professor pode auxiliá-lo a descobrir o problema e juntos podem tentar encontrar uma possível solução. Quando o aluno consegue identificar o seu erro sozinho, mostra uma evolução no domínio do conteúdo, pois, se ele sabe onde errou e sabe corrigir é porque algo, de fato, foi aprendido. Muitos professores não possuem essa prática, assim seus alunos seguem com os erros até o Ensino Médio.

Segundo BROUSSEAU (2008, p. 91), "a devolução é o ato pelo qual o professor faz com que o aluno aceite a responsabilidade de uma situação de aprendizagem ou de um problema e assume ele mesmo as consequências dessa transferência". Tal devolução, quando feita corretamente, utiliza o erro como ferramenta pedagógica essencial,

[...] assim, entre a solução errada dada por um aluno a um problema matemático e a possível reformulação dessa solução pelo mesmo aluno, há um período de tutelagem em que ele se apoia no conhecimento do professor ou no dos colegas mais experientes, para desenvolver o seu pensamento até poder retomar o problema e solucioná-lo, novamente sozinho, mas, agora, usando os instrumentos conceituais ou metodológicos adquiridos no convívio social. (CURY, 1994, p. 239) 


\subsection{EFEITO TOPÁZIO, CONTRATO DIDÁTICO E TRANSPOSIÇÃO DIDÁTICA}

Neste trabalho serão citados os conceitos de Efeito Topázio, Contrato Didático e Transposição Didática. Para melhor compreensão do texto, segue uma breve síntese sobre tais conceitos.

\section{Efeito Topázio}

Para Pais, o Efeito Topázio se dá quando o aluno apresenta dificuldade e o professor é levado a acelerar o processo de aprendizagem antecipando o resultado a que o aluno deveria chegar pelo seu próprio esforço. Por exemplo, quando o professor faz uma pergunta e, na ansiedade de uma resposta correta, ele acaba antecipando a fala dos alunos e respondendo sua própria questão.

Muitas vezes, em nome do que se costuma ter como máxima relação didática, o professor quer ser amigo dos alunos, e, para isso, passa a ensinar só aquelas partes do assunto que o aluno tem mais facilidade de aprender. Assim, o aluno tem bons resultados na prova e enxerga o professor como "bom", por explicar bem e ser amigo dos alunos. Esse tipo de atitude também é um exemplo do Efeito Topázio.

\section{Contrato Didático}

Chama-se contrato didático o conjunto de acordos bilaterais entre professor e aluno. São condições implícitas e explícitas que determinam aquilo que cada um dos dois parceiros da relação didática tem responsabilidade de gerenciar, e do que tem que prestar conta ao outro. Por exemplo, D'Amore (2007) cita o problema da Idade do Capitão ${ }^{4}$, em que o aluno assume algumas regras que costumam existir em sala de aula: sempre há uma resposta para um problema matemático e o professor a conhece; os dados para resolução sempre estão no enunciado; em Matemática sempre se resolve problemas efetuando operações; as soluções devem ser simples; as questões não têm nenhuma relação com a realidade cotidiana etc.

O professor é responsável por garantir ao aluno o acesso ao saber escolar e por definir a forma de sua participação no processo de aprendizagem. Já o aluno deve responder a essas

\footnotetext{
${ }^{4} \mathrm{O}$ problema da Idade do Capitão tem o seguinte enunciado: "Em um barco há 26 carneiros e 10 cabras. Qual é a idade do capitão?" e foi aplicado a 97 crianças de 8 e 9 anos da cidade de Genoble, na França, em 1980. 78\% dos alunos responderam combinando números do enunciado.
} 
diretrizes e determinações, resolvendo as tarefas propostas, ajustando-se aos moldes de comunicação social convencionados para as diferentes atividades escolares.

Em uma situação de ensino, preparada e realizada por um professor, o aluno normalmente tem como tarefa resolver o problema (matemático) que lhe é apresentado, mas o acesso a essa tarefa é feito por meio da interpretação das questões colocadas, das informações fornecidas, das obrigações impostas que são constantes no modo de ensinar do professor. Esses hábitos (específicos) do professor esperados pelos alunos e os comportamentos do aluno esperados pelo docente constituem o contrato didático. (Brousseau apud D’AMORE, 2007, p.101)

A prática mais usual é o professor cumprindo o seu papel com aulas expositivas e os alunos sempre resistentes às mudanças. Porém, muitas vezes essas expectativas não são explícitas, mas devidas à própria concepção de escola.

\section{Transposição Didática}

A Transposição Didática pode ser analisada a partir de três saberes: saber científico (desenvolvido nas universidades, associado à vida acadêmica - artigos, teses, livros), saber a ensinar ou saber escolar (ligado a uma forma didática que serve para apresentar o saber ao aluno - livros didáticos, programas e materiais de apoio) e saber ensinado (registrado no plano de aula do professor e que, não necessariamente, coincide com as intenções do saber a ensinar).

O trabalho do professor ao transformar um objeto de saber a ensinar em um objeto de ensino é chamado Transposição Didática. O matemático profissional constrói o saber matemático (acadêmico ou científico), o resultado final é organizado da maneira mais geral possível: descontextualizado, despersonalizado e atemporal. O professor de Matemática transmite o saber, recontextualiza as ideias, repersonaliza os problemas e possibilita a construção de significado pelo aluno. Assim, o conhecimento construído vira saber ensinado.

Um conteúdo do conhecimento tendo sido designado como saber a ensinar, sofre então um conjunto de transformações adaptativas que vão troná-lo apto a tomar lugar entre os 'objetos de ensino'. O 'trabalho' que, de um objeto de saber a ensinar faz um objeto de ensino, é chamado de transposição didática. (Chevallard apud PAIS, 2001, p. 19) 


\section{O TRABALHO REALIZADO}

Com a finalidade de identificar algumas dificuldades básicas de nível Fundamental que ainda se apresentam ao final do Ensino Médio, foi elaborado um questionário ${ }^{5} \mathrm{com}$ foco em algumas questões de álgebra e aritmética. Esse questionário foi aplicado para alunos do $3^{\circ}$ ano do Ensino Médio e do $1^{\circ}$ ano do Ensino Superior. Os dados obtidos foram analisados de forma quantitativa e qualitativa.

A partir da análise dos erros cometidos por esses alunos, pôde-se observar o perfil dos alunos que se encontram nessa fase de ensino e foi elaborado um segundo questionário ${ }^{6}$ com foco em resolução de equações, a fim de conseguir abranger as dificuldades mais frequentes encontradas nos questionários iniciais. Tal questionário foi aplicado para novos alunos do $3^{\circ}$ ano do Ensino Médio e suas respostas também foram analisadas.

Para tentar compreender o porquê da persistência das dificuldades identificadas, alguns dos alunos que responderam ao segundo questionário foram selecionados para participar de uma entrevista no qual, além de responder a algumas perguntas novas, deveriam tentar explicar seu raciocínio durante a resolução do questionário.

Para Cury (2013), a análise da produção escrita dos estudantes é uma possibilidade de trabalho que pode ser considerada sob o ponto de vista da investigação ou do ensino. Ela enfatiza que essa análise não deve ser confundida com uma avaliação e que, metodologicamente, se baseia na análise de conteúdo. Sendo assim, a análise dos questionários aplicados seguida de entrevistas com os alunos tomará essa linha.

Durante a aplicação do segundo questionário, a professora de Matemática da turma estava na classe; sendo assim, foi possível observar um pouco do contrato didático vigente na sala de aula, assim como algumas situações nas quais o efeito topázio foi bem evidente. Já durante as entrevistas com os alunos, o contrato didático foi reforçado e eles comentaram sobre as aulas e os métodos utilizados por seus professores anteriores, mostrando um pouco da transposição didática feita por cada um.

A análise, o detalhamento do processo e suas conclusões serão vistos mais adiante.

\footnotetext{
${ }^{5}$ Apêndice 1.

${ }^{6}$ Apêndice 2.
} 


\section{PRIMEIRO QUESTIONÁRIO}

Com a finalidade de analisar algumas situações na série final do Ensino Médio e nos semestres iniciais de cursos superiores, foram escolhidos alguns tópicos para elaborar um questionário inicial que auxiliaria na identificação dos problemas. Sabendo que a álgebra e a aritmética são base para conteúdos mais avançados da Matemática e também são muito utilizadas em geometria, as questões tiveram esse foco, além de ser considerado um tema de vital importância para alunos do $3^{\circ}$ ano do Ensino Médio.

A aplicação do questionário foi feita em São Paulo, no início do ano letivo de 2014, a duzentos e vinte alunos, sendo:

- 91 alunos do primeiro ano do Ensino Superior de uma universidade pública do Estado de São Paulo: 58 do curso de Licenciatura em Física e 33 do curso de Licenciatura em Matemática;

- 129 alunos do terceiro ano do Ensino Médio de duas escolas particulares da cidade de São Paulo.

Os alunos de Ensino Médio foram escolhidos por serem o foco principal desta pesquisa. Já os alunos da Universidade foram escolhidos por serem aqueles que, em teoria, têm preferência ou facilidade por disciplinas da área de exatas.

O questionário consistia em seis questões, que serão detalhadas a seguir, com temas relativos a todo o Ensino Fundamental, mas que, em sua essência, todas envolviam as operações com números reais. As questões foram elaboradas com base em observações pessoais feitas sobre os erros cometidos pelos alunos em sala de aula. Esses erros podem ser notados no dia a dia em resoluções de problemas, exercícios de álgebra ou de geometria, portanto foram considerados de suma importância e selecionados para compor o questionário. 


\subsection{ANÁLISE}

\section{Descrição das questões}

\section{QUESTÃO 01}

A primeira questão tinha por enunciado: “Calcular, se possível, o valor das expressões aritméticas a seguir" e era composta por quatro itens:

- Item A: $(-6+4) \cdot(-1-3)+2 \cdot(-8+3)-(7+3) \div(3-5)$.

Este item foi selecionado com o objetivo de avaliar as operações com números inteiros e a resolução de expressões, assim como a famosa "regra de sinais". É muito comum ouvir o aluno dizer que "menos com menos dá mais" e, generalizando, essa regra é aplicada para todas as operações, não só para multiplicação e divisão, gerando erros do tipo $-5-10=+15$. A ordem das operações também foi relevante, pois é comum os alunos resolverem todas as operações e deixarem a divisão para o final.

- Item B: $(-2)^{2}+(-2)^{3}-2^{2}-2^{3}$.

Este item foi selecionado com o objetivo de avaliar as operações com números inteiros, focando principalmente na potenciação e recaindo também na "regra de sinais". O uso dos parênteses também foi analisado, pois alguns alunos acham que não há necessidade e assim o resultado, com ou sem parênteses, daria o mesmo.

- Item C: $\frac{1-\frac{1}{2}}{\frac{3}{4}}+\frac{1}{3}$

Este item foi selecionado com o objetivo de avaliar as operações com números racionais e a resolução de expressões. Operações com frações são um desafio até para certos professores do Ensino Fundamental I. Infelizmente, alguns decoram os algoritmos e apenas os transmitem aos alunos sem sequer saber o seu real significado e origem. E, consequentemente, por não dominar o conteúdo, acabam deixando de lado ou abordando tal tema rapidamente. Esse é um problema comum devido à falta de formação específica dos professores desse ramo, como já foi dito por 
Santos (2014). Além disso, muitas vezes os alunos têm o hábito de generalizar o conceito, por exemplo, o algoritmo utilizado para a adição muitas vezes é usado na multiplicação ou vice versa, gerando erros do tipo $\frac{2}{7}+\frac{3}{4}=\frac{2+3}{7+4}=\frac{5}{11}$ ou $5 \cdot \frac{2}{3}=\frac{5 \cdot 2}{5 \cdot 3}=\frac{10}{15}$.

- Item D: $\frac{3}{4+5-9+7-3-4}$.

Este item foi selecionado com o objetivo de avaliar os conceitos de divisão. Muitos alunos não sabem como resolver a divisão por zero. Para eles não se trata de uma operação impossível, mas sim uma conta como outra qualquer em que o resultado, na maioria dos casos, é igual a zero. As operações envolvendo o número zero, em geral, geram muitas dúvidas para os alunos.

\section{QUESTÃO 02}

A segunda questão tinha por enunciado: "Determinar, se possível, o valor de $a$ em cada caso" e era composta por dois itens:

- Item A: $3 a+5=5(a+3)$.

Este item foi selecionado com o objetivo de avaliar as operações com números inteiros, focando principalmente na resolução de equações do primeiro grau. Quando os alunos aprendem equação no sétimo ano, muitos professores dizem a frase: "passa para o outro lado e troca o sinal". Os alunos prontamente decoram essa regra e isso acaba gerando erros do tipo $-2 x=8 \Leftrightarrow x=\frac{8}{2}$ ou $-5 x=0 \Leftrightarrow x=0+5$. Segundo Sperafico e Golbert (2012), no $7^{\circ}$ ano esse tipo de erro é inevitável, pois o aluno está testando estratégias e estabelecendo relações entre novos conhecimentos. Acredito, porém, que no final do Ensino Médio, não deveria ser mais um erro esperado.

- Item B: $a^{2}-2 a-8=0$.

Este item foi selecionado com o objetivo de avaliar as operações com números reais, focando principalmente na resolução de equações do segundo grau, além de observar o manuseio 
de duas informações sendo representadas pela mesma incógnita. Durante a sua resolução, o aluno se depara com uma raiz não exata, o que é pouco comum, dado que em boa parte dos exercícios aparecem apenas quadrados perfeitos que facilitam a sua resolução e explicação.

\section{Análise geral por questão}

Para fazer a análise dos erros encontrados nas questões, será criada aqui uma classificação, tomando como base os autores Cury (2013), Radatz (1979), Vinner, Hershkowitz e Bruckheimer (1981). No que segue desta pesquisa, usaremos essa classificação. Os erros serão agrupados em 5 classes:

- Erros devido ao cálculo incorreto: são, em sua maioria, erros de conta, mas também podem ser oriundos de descuidos ou falta de atenção.

- Erros devido à dificuldade na linguagem ${ }^{7}$ : são apresentados na utilização de conceitos, vocabulário e símbolos matemáticos, e/ou ao efetuar a passagem da linguagem corrente para a linguagem matemática. Os erros de interpretação de enunciado também se encaixam nesse caso.

- Erros devido a uma aprendizagem prévia deficiente: são os cometidos por deficiências em alguns pré-requisitos matemáticos, como manipulação de algoritmos, fatos básicos, procedimentos, símbolos e conceitos matemáticos. Como resultado, os alunos não têm uma compreensão de por que ou como um procedimento funciona, não reconhecendo a importância de aplicá-lo corretamente.

- Erros devido à generalização de regras $^{8}$ : são produzidos por aplicação de regras ou estratégias semelhantes em diferentes conteúdos. Os alunos falsamente relacionam

\footnotetext{
7 "wrong interpretation of symbols" (interpretação errada dos símbolos), em que "é natural que o aluno decida que o denominador deve ser somado com o denominador e o numerador deve ser somado com o numerador, pois em muitos casos, somamos somente aquilo que pertence à mesma categoria: maçãs com maçãs, cadeiras com cadeiras, dezenas com dezenas e centenas com centenas". (VINNER, HERSHKOWITZ e BRUCKHEIMER, 1981, p. 72, tradução nossa)

8 "wrong analogy" (analogia errada), em que o aluno tem um raciocínio do tipo: "como, para multiplicar duas frações, devo multiplicar os numeradores e os denominadores, respectivamente, então, para adicioná-las, devo somar os numeradores e os denominadores, respectivamente". (VINNER, HERSHKOWITZ e BRUCKHEIMER, 1981, p. 72 , tradução nossa)
} 
problemas de Matemática que usam símbolos similares e tentam criar significado nos padrões de símbolos e sinais que lhes são apresentados.

- Erros devido à rigidez de raciocínio9: são causados pela falta de flexibilidade no pensamento para adaptarem-se a novas situações, muitas vezes mais simples do que aquela na qual persistem. Os alunos tornam habituais determinados tipos de raciocínio e continuam a utilizá-los mesmo quando as condições matemáticas se alteram.

A seguir, com base nessas ideias, nos questionários aplicados e em investigações pessoais, foi feita uma análise dos erros cometidos pelos alunos e obtiveram-se os seguintes resultados para cada item citado anteriormente:

9 “misidentification" (falta de identificação), em que "o aluno utiliza um algoritmo apropriado para uma situação em outra onde ele não se aplica". (VINNER, HERSHKOWITZ e BRUCKHEIMER, 1981, p. 72, tradução nossa) 
Questão 01A: Calcular $(-6+4) \cdot(-1-3)+2 \cdot(-8+3)-(7+3) \div(3-5)$.

\begin{tabular}{lc}
\hline \multicolumn{2}{c}{ Questão 01 - item A } \\
\hline Correto & $40,0 \%$ \\
Fez tudo dividido por (-2) & $28,6 \%$ \\
Erro de sinal & $21,4 \%$ \\
Erro de conta & $11,4 \%$ \\
Adição / subtração com negativos & $10,0 \%$ \\
Ordem das operações & $7,3 \%$ \\
Copiou errado & $0,9 \%$ \\
Fez a distributiva da divisão & $0,9 \%$ \\
Em branco & $0,5 \%$ \\
Cancelou o denominador & $0,5 \%$ \\
Tirou os parênteses sem fazer a conta & $0,5 \%$ \\
Simplificou a fração na soma & $0,5 \%$ \\
\hline \multicolumn{2}{c}{ Tabela 1 - Resolução da Questão 01A }
\end{tabular}

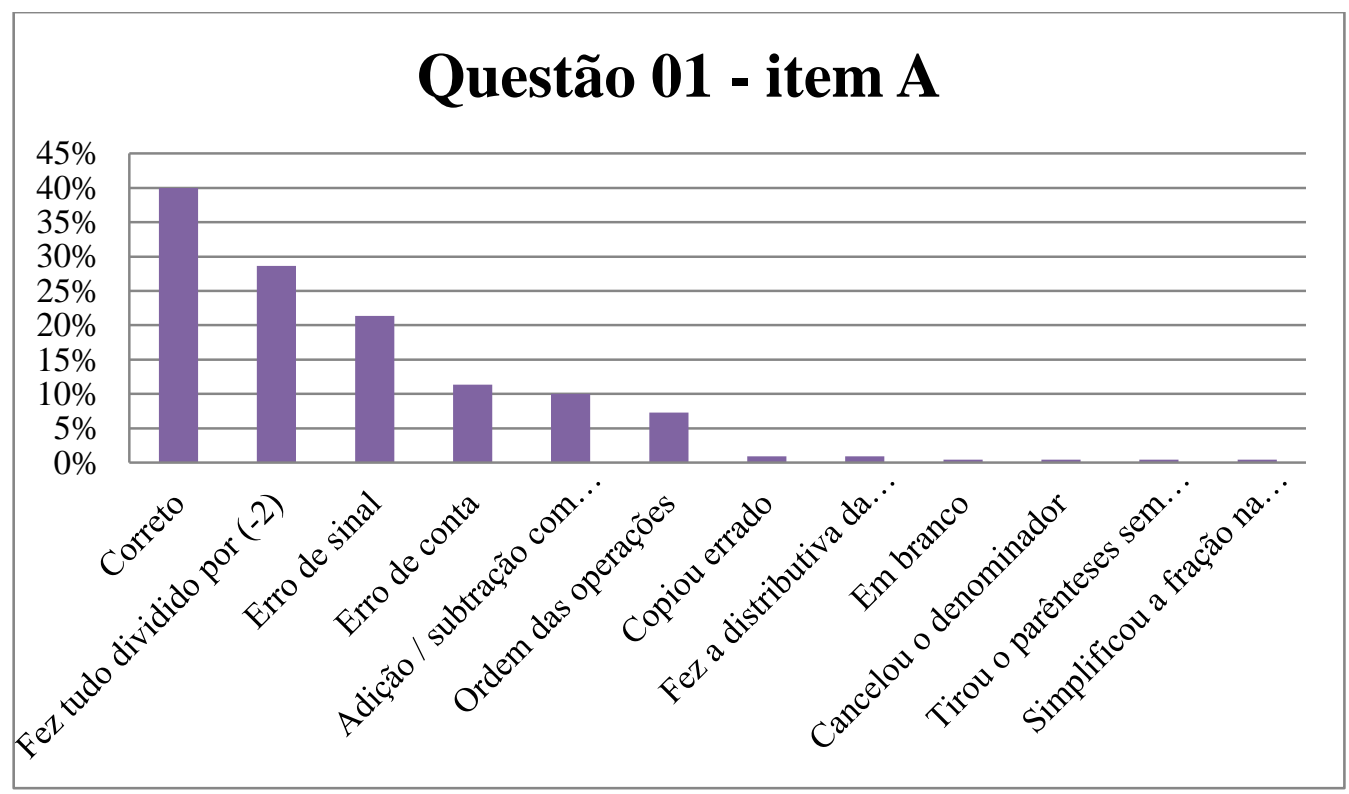

Gráfico 1 - Resolução da Questão 01A

O erro mais frequente está relacionado com a ordem das operações na expressão, pois dividir toda a expressão por (-2) também é uma inversão da ordem das operações. Os erros de sinais também foram muito presentes, assim como nas operações com números inteiros. Esse tipo 
de erro pode ocorrer devido à memorização de regras e algoritmos para o cálculo requisitado. Nesse caso, seriam erros devidos a uma aprendizagem prévia deficiente. A seguir alguns exemplos específicos.

$$
\begin{aligned}
& (-6+4) \cdot(-1-3)+2 \cdot(-8+3)-(7+3) \div(3-5) \\
& +6+18-4-12-16+6-\left(\frac{7}{3}-\frac{7}{5}+1-\frac{3}{5}\right) \\
& 30-32-\frac{7}{3}+\frac{7}{5}\left(-1+\frac{3}{5}\right)=-2-\frac{14}{15}+\frac{2}{5}
\end{aligned}
$$

Figura 1 - Resolução de aluno

Nesse caso, o aluno generalizou um processo que ele aprendeu para multiplicação e aplicou a propriedade distributiva para a divisão, sendo claramente um erro devido à generalização de regras.

$$
\begin{aligned}
& (-6+4) \cdot(-1-3)+2 \cdot(-8+3)-(7+3) \div(3-5) \\
& \frac{(-2)(-4)+(-10)}{-2} \Rightarrow \frac{8+(-18)}{-2}=\frac{10}{2}=-5
\end{aligned}
$$

Figura 2 - Resolução de aluno

Já nesse exemplo o erro mais evidente foi que o aluno entendeu que toda a expressão estava dividida por (-2). Porém também é possível notar alguns problemas com as operações com números inteiros, já que ele fez $-(7+3)=-8$ e $8+(-18)=10$. Nesse caso, o aluno apresentou alguns erros devidos aos cálculos incorretos e talvez um pouco de aprendizagem prévia deficiente, juntamente com uma dificuldade na linguagem.

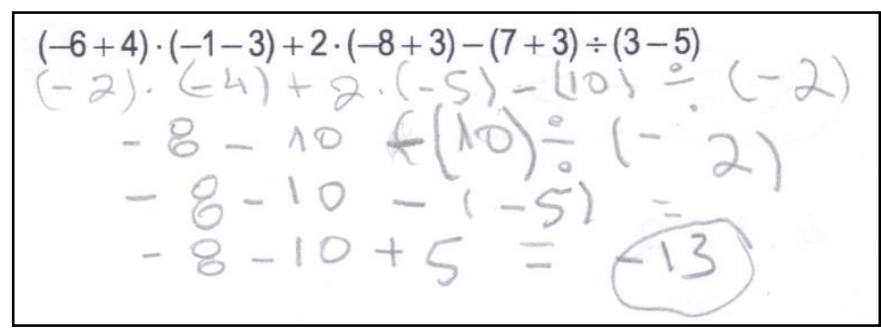

Figura 3 - Resolução de aluno

Aqui se vê uma dificuldade com a multiplicação envolvendo números negativos, pois o 
aluno fez $(-2) \cdot(-4)=-8$. D'Amore (2007) citas alguns "materiais" criados para auxiliar na transposição didática, mas que acabam atrapalhando o aprendizado do aluno, como, por exemplo, o "empresta 1", "menos com menos dá mais", "passa pro outro lado e troca o sinal" etc. Nesse caso, claramente a regra de que "menos com menos dá mais" não foi absorvida e muito menos compreendida para que fosse utilizada nesse exercício. Pode-se também classificar esse erro como devido a uma aprendizagem prévia deficiente.

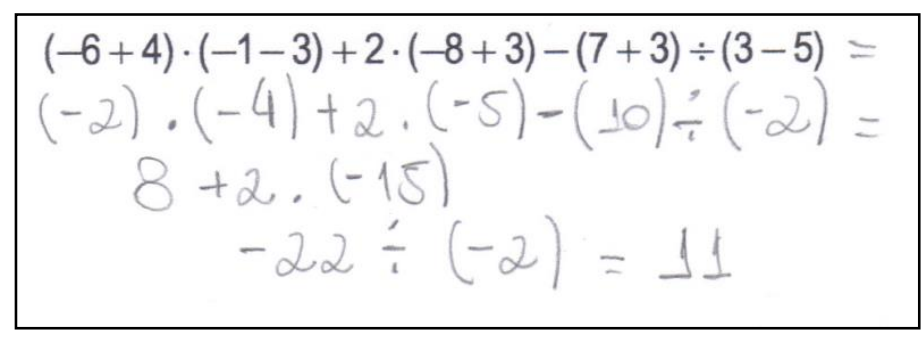

Figura 4 - Resolução de aluno

Nesse caso temos um problema com a ordem das operações. Como o aluno não compreendeu que a multiplicação é um conjunto de adições, a ideia da ordem das operações não formou significado em sua cabeça, sendo assim ele não viu problema em resolver primeiro a subtração $(-5)-(10)$ antes da multiplicação $2 \cdot(-5)$ e da divisão $(10) \div(-2)$. Esse erro pode ser devido à aprendizagem prévia deficiente ou dificuldade na linguagem. 
Questão 01B: Calcular $(-2)^{2}+(-2)^{3}-2^{2}-2^{3}$.

\begin{tabular}{lc}
\hline \multicolumn{2}{c}{ Questão 01 - item B } \\
\hline Correto & $61,4 \%$ \\
Erro de sinal & $34,5 \%$ \\
Erro com a potência de 2 & $3,2 \%$ \\
Erro de conta com negativos & $1,8 \%$ \\
Em branco & $0,5 \%$ \\
Copiou errado & $0,5 \%$ \\
\hline
\end{tabular}

Tabela 2 - Resolução da Questão 01B

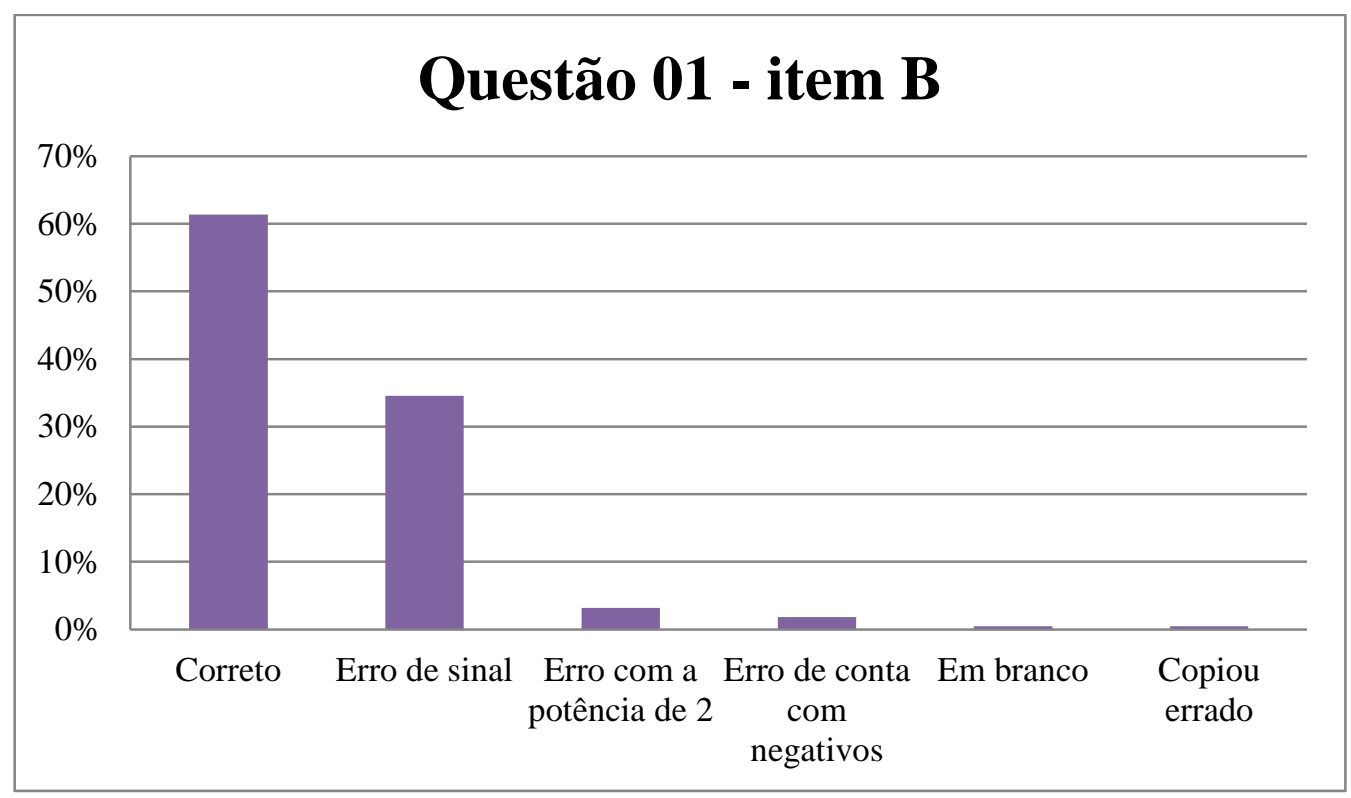

Gráfico 2 - Resolução da Questão 01B

O erro mais frequente nesta questão foi o de sinal. Por se tratar de uma questão de potenciação, os parênteses e os sinais foram colocados de forma a induzir às situações mais comuns de erros. Observem-se alguns casos específicos.

$$
\begin{aligned}
& (-2)^{2}+(-2)^{3}-2^{2}-2^{3} \\
& 4+8-4-8=0
\end{aligned}
$$

Figura 5 - Resolução de aluno 
Nesse caso o aluno faz $(-2)^{3}=8$, pois, pode ter estendido a ideia que viu para números elevados ao quadrado, quando números negativos, quando elevados a determinadas potências, ficam positivos. Esse erro pode ser devido a uma generalização de regras ou a uma aprendizagem prévia deficiente em que o conceito de potenciação não foi absorvido.

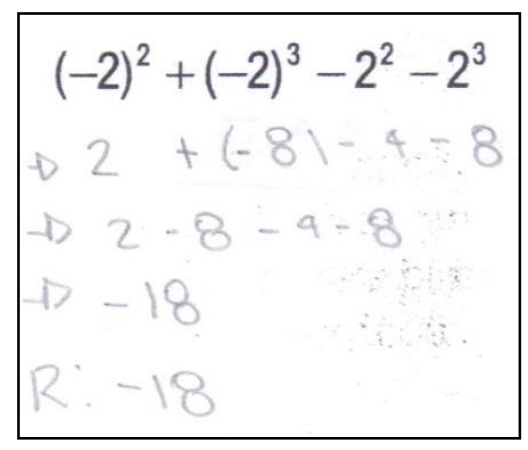

Figura 6 - Resolução de aluno

Aqui temos um erro de possível falta de atenção, no qual o aluno fez $(-2)^{2}=2$. Pode-se ver pelas outras passagens que ele sabe os conceitos de potenciação e administrou bem os sinais, tratando-se, provavelmente, de um erro devido ao cálculo incorreto.

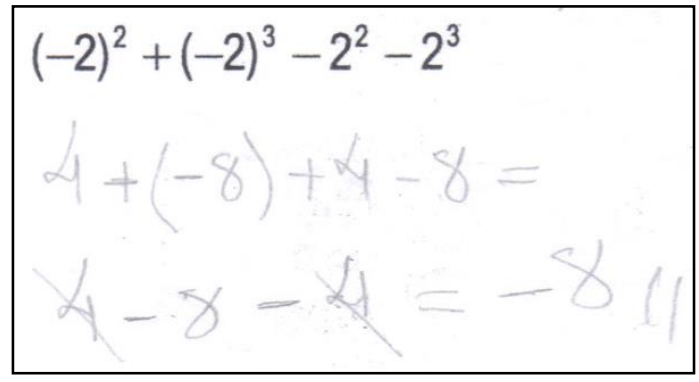

Figura 7 - Resolução de aluno

Nesse último caso, aparece o erro mais comum aos alunos que trabalham com potência de números negativos. Para este aluno, $(-2)^{2}=-2^{2}=4$. Esse erro também remete ao problema com a ordem das operações e a ideia de que os parênteses podem modificar essa ordem. $\mathrm{O}$ aluno não percebe que se trata de $(-2) \cdot(-2)$ e $-2 \cdot 2$, que possuem resultados diferentes. Logo, esse erro se deve à uma aprendizagem prévia deficiente juntamente com a dificuldade na linguagem. 
Questão 01C: Calcular $\frac{1-\frac{1}{2}}{\frac{3}{4}}+\frac{1}{3}$.

\begin{tabular}{lc}
\hline \multicolumn{2}{c}{ Questão 01 - item C } \\
\hline Correto & $61,4 \%$ \\
Em branco & $12,3 \%$ \\
Ordem das operações & $8,2 \%$ \\
Adição / subtração de frações & $7,7 \%$ \\
Divisão de frações & $4,5 \%$ \\
Incompleto & $2,7 \%$ \\
Transformação em decimal & $2,3 \%$ \\
Erro de conta & $1,8 \%$ \\
Cancelou o denominador & $0,5 \%$ \\
Copiou errado & $0,5 \%$ \\
\hline Fez 6/6 = 0 & $0,5 \%$ \\
\hline
\end{tabular}

Tabela 3 - Resolução da Questão 01C

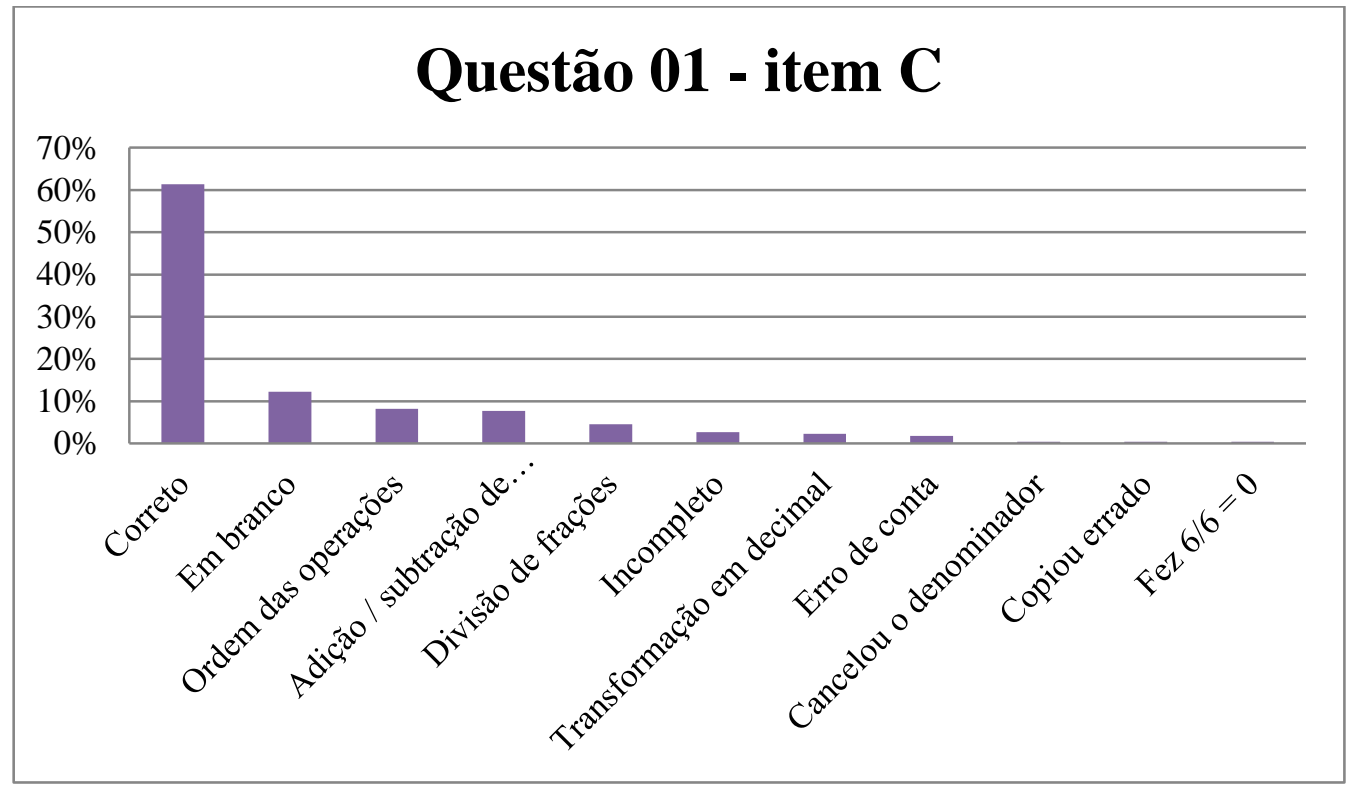

Gráfico 3 - Resolução da Questão 01C

Novamente nota-se um grande percentual de acerto, porém, nesse caso, a incidência de questões em branco é maior do que nos outros exercícios. Muitas vezes os alunos desistem de 
fazer o cálculo simplesmente pelo fato de ter que fazer contas com frações. As operações com número racionais são rejeitadas por muitos deles e também são evitadas por muitos de seus professores. Em sala de aula é comum frases do tipo "se aparecer fração, eu desisto" ou "pra complicar mais, só falta colocar fração". Esse assunto acaba se tornando um tabu e isso faz com que o único contato do aluno com esse tipo de número seja no início do Ensino Fundamental II quando ele aprende a trabalhar com frações. Note-se o que aconteceu em alguns exemplos.

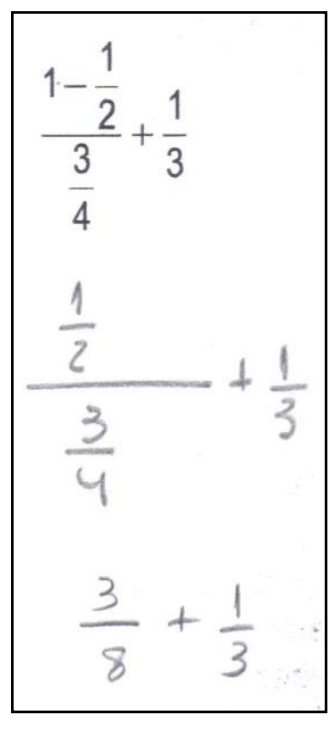

Figura 8 - Resolução de aluno

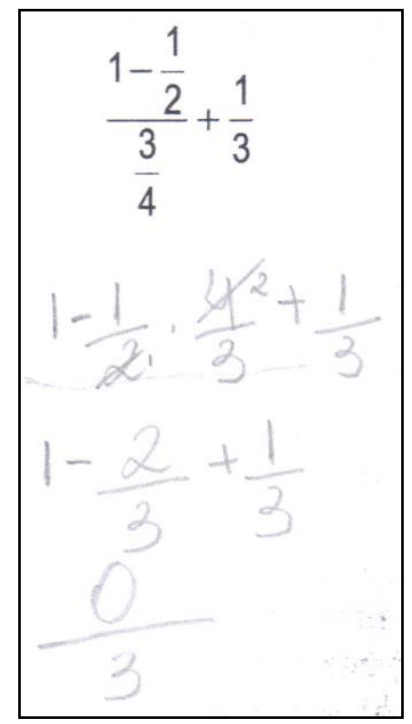

Figura 9 Resolução de aluno

No exemplo da esquerda tem-se uma divisão de frações em que $\frac{1}{2} \div \frac{3}{4}=\frac{1}{2} \cdot \frac{3}{4}=\frac{3}{8}$. Mais uma vez o conceito não foi absorvido nem memorizado. Já no exemplo da direita, o aluno quis colocar a expressão em sua forma horizontal, porém se esqueceu de alguns parênteses para manter a ordem das operações que seriam realizadas. Em ambos os casos, têm-se erros devidos a uma aprendizagem prévia deficiente, porém, no caso da direita, ainda pode-se observar uma dificuldade na linguagem.

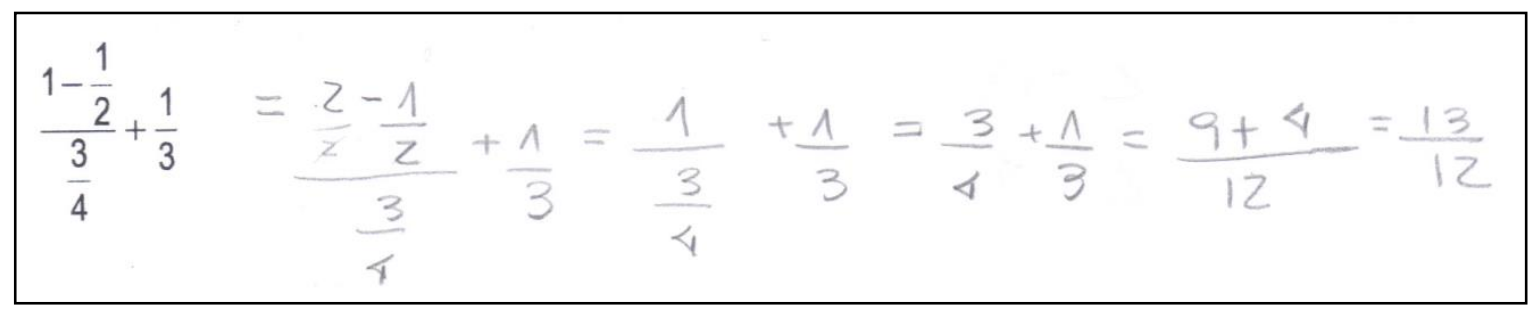

Figura 10 - Resolução de aluno 


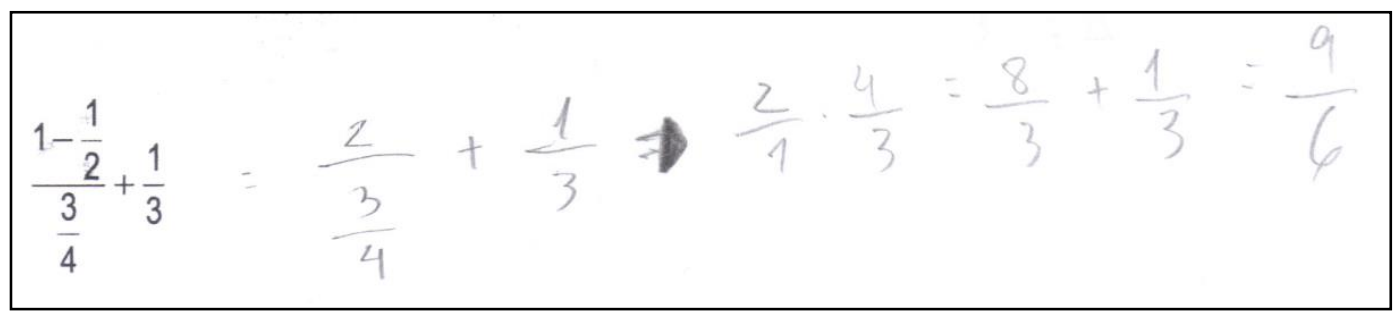

Figura 11 - Resolução de aluno

Nos dois exemplos anteriores houve um problema com a subtração $1-\frac{1}{2}$ em que é possível notar que os alunos não entenderam o conceito de frações equivalentes para trabalhar adição e subtração de frações. Esses alunos também não dominam o procedimento do mínimo múltiplo comum no qual se "divide pelo de baixo e multiplica pelo de cima". Nesse caso, têm-se erros devidos à dificuldade na linguagem, à aprendizagem prévia deficiente e até a uma possível rigidez de raciocínio.

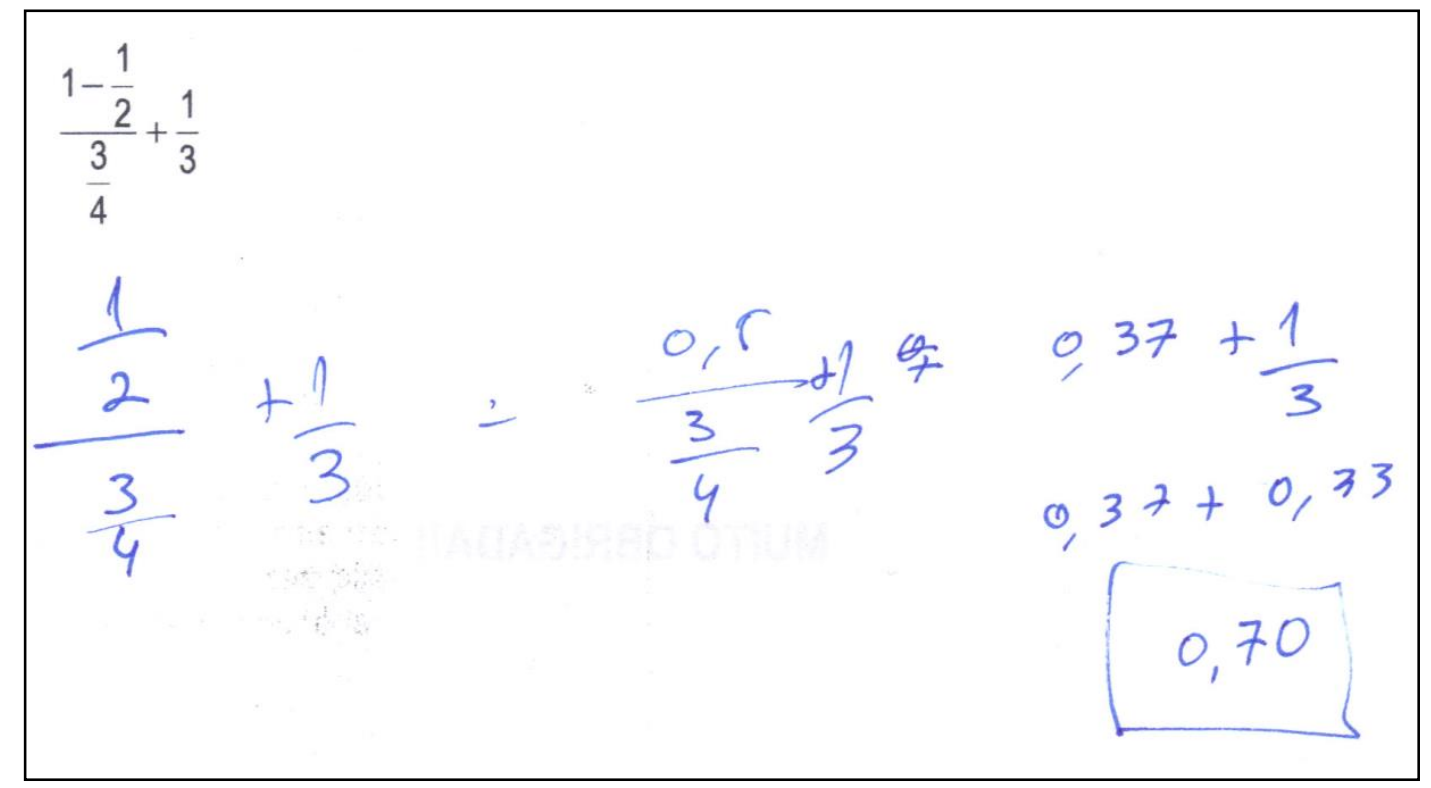

Figura 12 - Resolução de aluno

Nesse último caso, o aluno resolveu transformar as frações em decimais e acabou trabalhando com valores aproximados. Isso não seria um problema se o símbolo correto tivesse sido utilizado. Além desse detalhe, ao fazer a divisão $0,5 \div \frac{3}{4}=0,37$ é possível notar que o aluno não apresenta o domínio necessário para trabalhar com frações e decimais simultaneamente. 
Questão 01D: Calcular $\frac{3}{4+5-9+7-3-4}$.

\begin{tabular}{lc}
\hline \multicolumn{2}{c}{ Questão 01 - item D } \\
\hline Correto & $36,8 \%$ \\
Resposta 0 & $29,5 \%$ \\
Resposta 3 & $8,2 \%$ \\
Fez até 3 sobre 0 (incompleto) & $8,2 \%$ \\
Conjunto vazio & $6,4 \%$ \\
Em branco & $4,5 \%$ \\
Erro de conta & $4,1 \%$ \\
Resposta 1 & $1,4 \%$ \\
Separou em frações com diferentes denominadores & $0,5 \%$ \\
Infinito & $0,5 \%$ \\
\hline
\end{tabular}

Tabela 4 - Resolução da Questão 01D

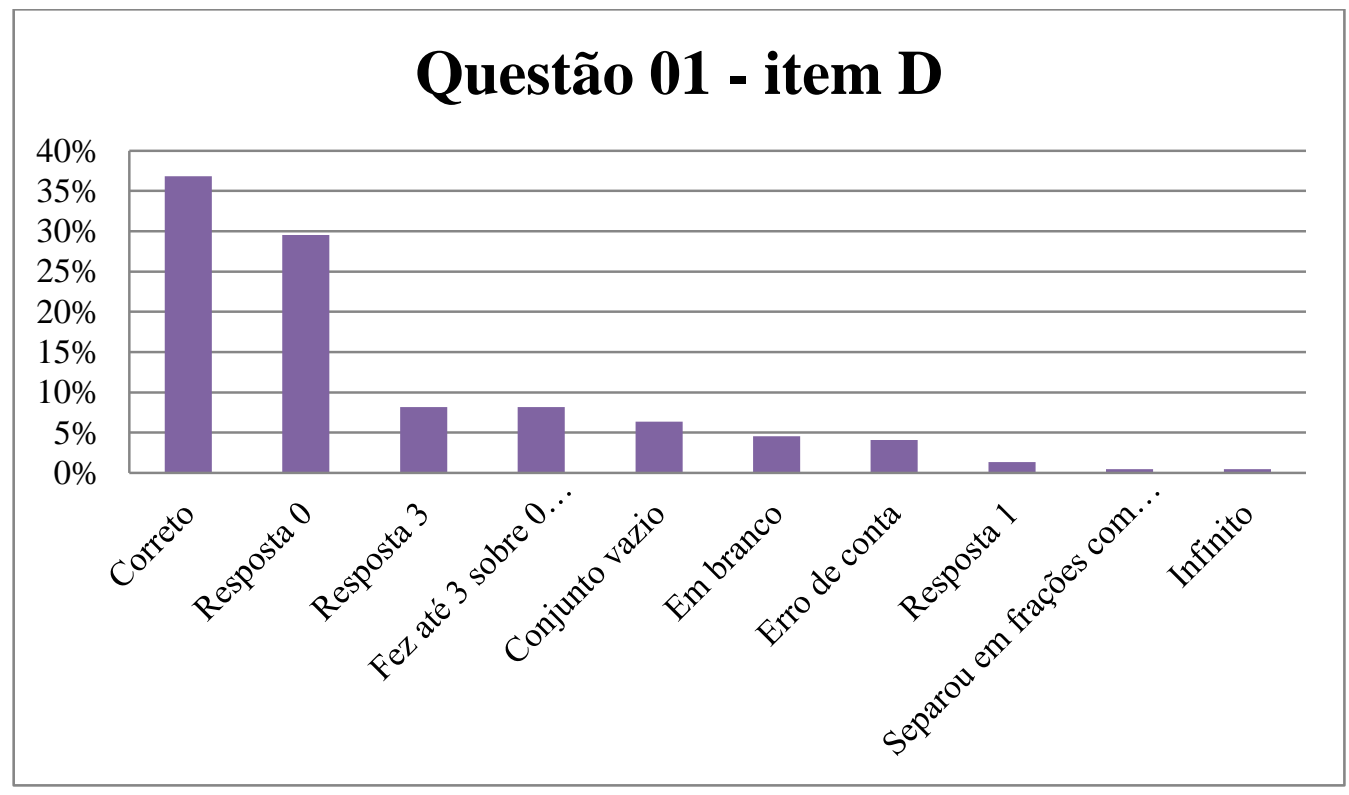

Gráfico 4 - Resolução da Questão 01D

Nessa questão, é possível notar que os alunos estão acostumados a chegar a um resultado numérico para os cálculos que fazem. Isso os forçou a dar respostas como 0 ou 3 , sem questionar a divisão por zero. Uma pequena porcentagem deixou incompleto ao chegar em $\frac{3}{0}$. 
Alguns podem ter tido dúvidas e outros podem ter achado que essa era a resposta final. Veja-se o que aconteceu em alguns casos.

$$
\frac{3}{4+5-9+7-3-4}=\frac{3}{-14}
$$

Figura 13 - Resolução de aluno

Este aluno teve um simples erro de conta, o que levou a sua expressão a um resultado racional. Nesse caso, é fácil classificar o erro com devido ao cálculo incorreto.

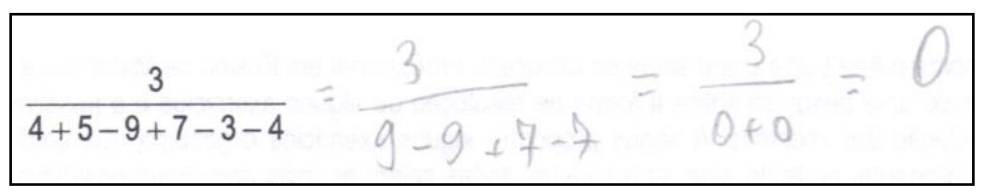

Figura 14 - Resolução de aluno

$\frac{3}{4+5-9+7-3-4}=\frac{3}{16-16}=3$

Figura 15 - Resolução de aluno

Nos dois casos acima, os alunos não viram problema algum na divisão por zero, porém cada um deu uma resposta diferente. Isso ocorreu com uma frequência grande e, muitas vezes, eles também têm dificuldade de entender por que tal divisão não é possível. Sendo assim, esse erro pode ser devido a uma aprendizagem prévia deficiente ou a uma rigidez de raciocínio.

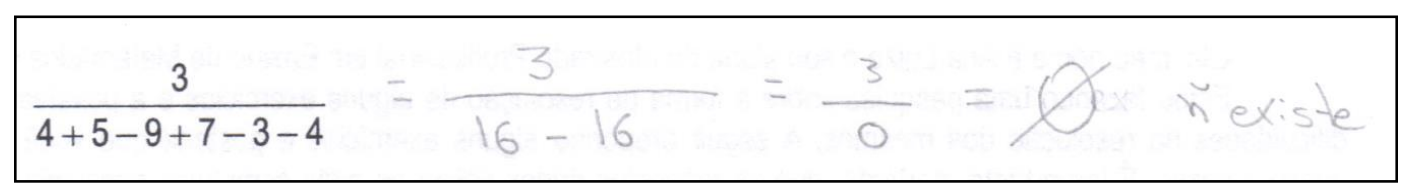

Figura 16 - Resolução de aluno

Já este aluno observou que a divisão não era possível, porém utilizou erradamente o símbolo de conjunto vazio como resultado de uma expressão numérica. Eles estão acostumados a colocar como solução o conjunto vazio, mas não prestaram atenção que não se tratava de uma equação. Esse erro pode ter sido devido a uma generalização de regras ou a uma dificuldade de linguagem. 
Questão 02A: Resolver $3 a+5=5(a+3)$.

\begin{tabular}{lc}
\hline \multicolumn{2}{c}{ Questão 02 - item A } \\
\hline Correto & $76,8 \%$ \\
\hline Erro de sinal & $6,8 \%$ \\
Em branco & $5,9 \%$ \\
Não fez distributiva & $5,0 \%$ \\
\hline Fez Bháskara & $2,3 \%$ \\
\hline Erro de conta & $1,8 \%$ \\
Fez a+3=3a & $0,9 \%$ \\
Copiou errado & $0,5 \%$ \\
Passou o -2 somando & $0,5 \%$ \\
\hline Fez um produto notável & $0,5 \%$ \\
\hline \multicolumn{2}{c}{ Tabela 5 - Resolução da Questão 02A }
\end{tabular}

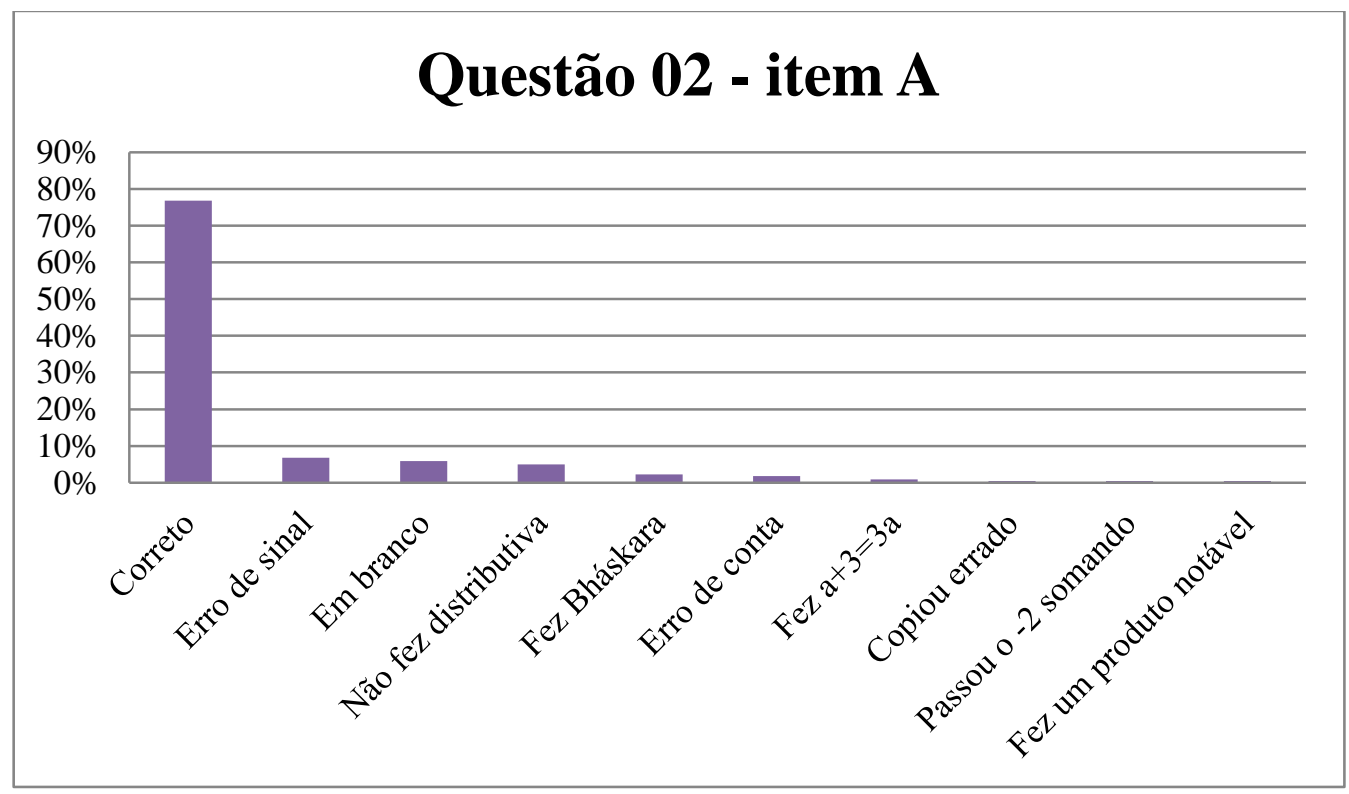

Gráfico 5 - Resolução da Questão 02A

Esta questão foi a que teve o maior percentual de acerto. Os erros ficaram entre os de sinal, os de conta, e alguns problemas com a linguagem. Vejam-se alguns exemplos que resumem os erros mais frequentes. 


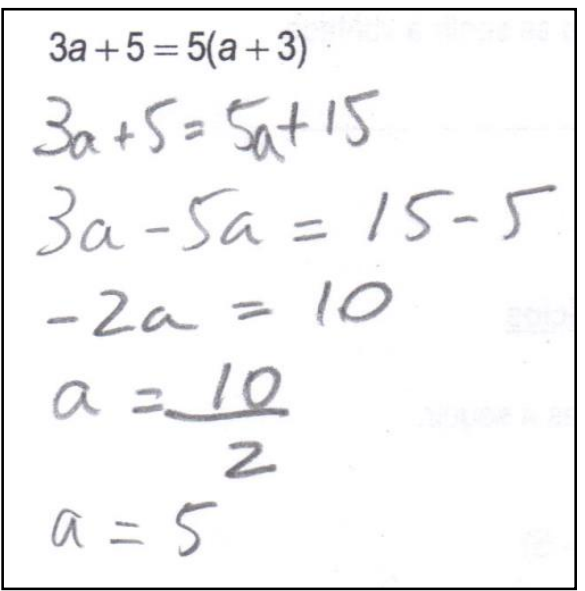

Figura 17 - Resolução de aluno

Nesse caso o aluno tem a equação $-2 a=10$, porém quando ele divide por 2 , acaba trocando o sinal. Isso pode acontecer porque os professores ensinaram que "quando muda de lado, troca o sinal" e assim o aluno decora o procedimento, aplica em qualquer situação e acaba seguindo um raciocínio errôneo. Trata-se então de um erro devido a uma aprendizagem prévia deficiente, pois o aluno não compreende o conceito de equação, mas, ao mesmo tempo, é um erro devido à generalização de regras por conta da transposição de uma "regrinha" que nem sempre é válida.

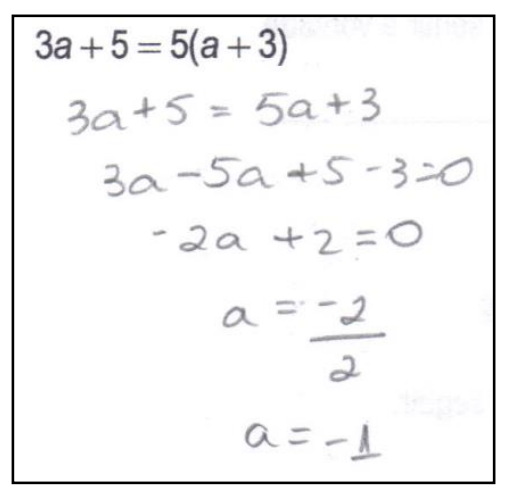

Figura 18 - Resolução de aluno

Já nesse caso, temos o mesmo problema anterior, pois o aluno transforma a equação $-2 a+2=0$ em $a=\frac{-2}{2}$. Mas, além disso, ao aplicar a propriedade distributiva, a multiplicação $5 \cdot 3$ não aconteceu. Então, este erro pode ser devido ao cálculo incorreto ou a uma aprendizagem prévia deficiente. 
Questão 02B: Resolver $a^{2}-4 a+2=0$.

\begin{tabular}{lc}
\hline \multicolumn{2}{c}{ Questão 02 - item B } \\
\hline Correto & $30,5 \%$ \\
\hline Simplificação da fração & $30,5 \%$ \\
Simplificação do radical & $27,3 \%$ \\
\hline Em branco & $8,2 \%$ \\
\hline Erro de fórmula & $5,9 \%$ \\
\hline Erro de conta & $4,5 \%$ \\
\hline Operações com radicais & $3,2 \%$ \\
\hline Incompleto & $2,7 \%$ \\
Resolveu como equação do primeiro grau & $1,8 \%$ \\
\hline Fez Bháskara com o a & $1,4 \%$ \\
Tirou a raiz dividindo o número por 2 & $1,4 \%$ \\
\hline Substituiu pelo número errado & $1,4 \%$ \\
Potência com negativo & $0,9 \%$ \\
Trocou sinal & $0,9 \%$ \\
\hline Fatorou o trinômio errado & $0,9 \%$ \\
\hline Sumiu com o denominador & $0,5 \%$ \\
Copiou errado & $0,5 \%$ \\
\hline Parou com delta = 0 & $0,5 \%$ \\
\hline Fez tentativas & $0,5 \%$ \\
\hline
\end{tabular}

Tabela 6 - Resolução da Questão 02B

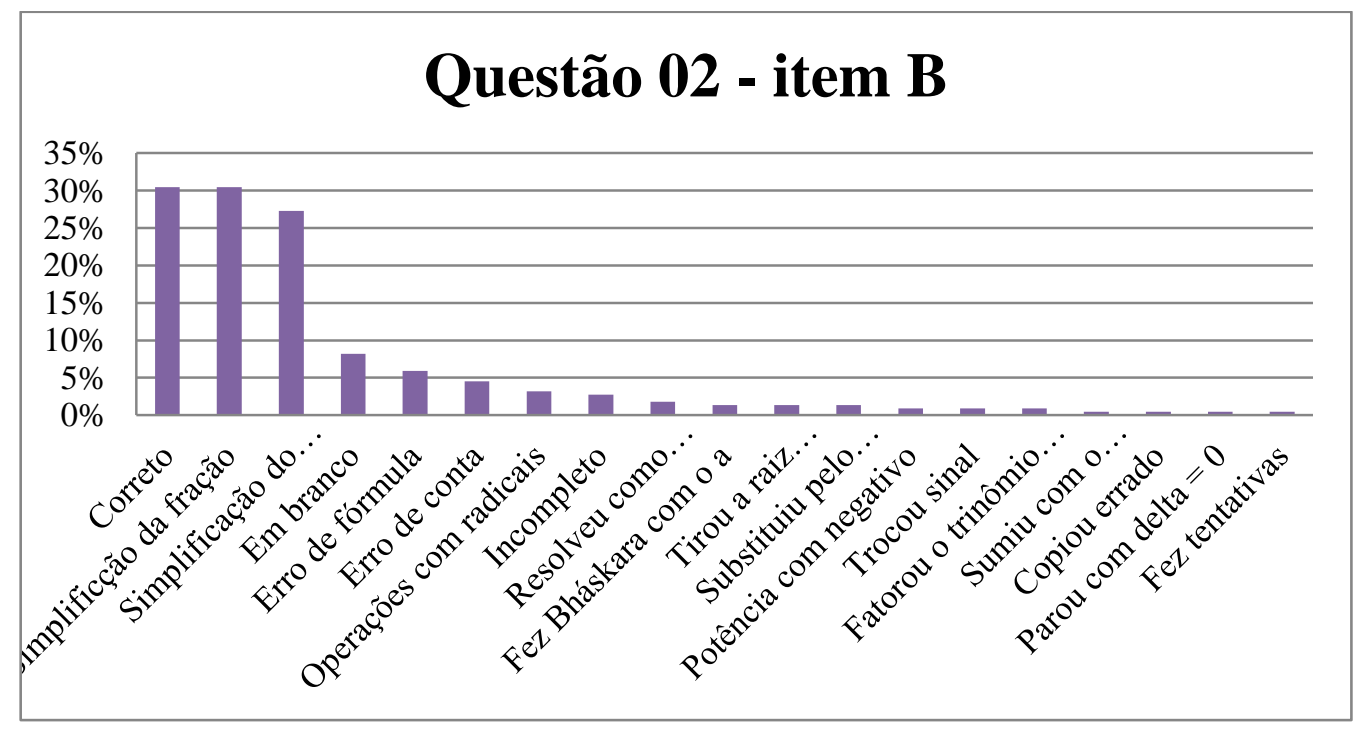

Gráfico 6 - Resolução da Questão 02B 
Nesta questão aparece mais uma vez o problema que os alunos têm com frações e, além disso, uma grande porcentagem de alunos teve dificuldade com a raiz quadrada não exata. Acredito que isso ocorra porque em geral os exercícios dos livros didáticos e até mesmo os selecionados pelo professor utilizam quadrados perfeitos para o valor do discriminante. Dessa forma, quando o aluno se depara com algo diferente disso, tende a achar que sua resposta está errada. Observem-se alguns casos a seguir.

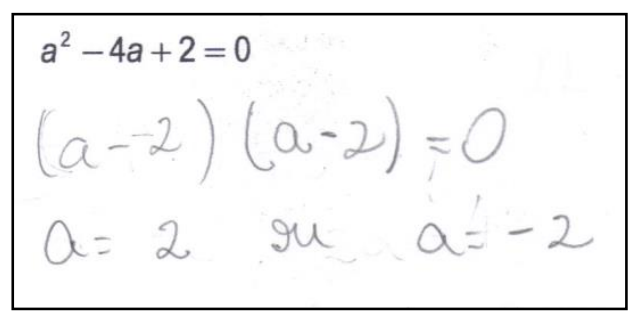

Figura 19 - Resolução de aluno

Neste caso trata-se de um erro conceitual em que o aluno confundiu os casos de fatoração. Isso ocorre porque, normalmente, o aluno decora quais são os casos e apenas aplica o esquema. Classifica-se, então, o erro como devido a uma aprendizagem prévia deficiente.

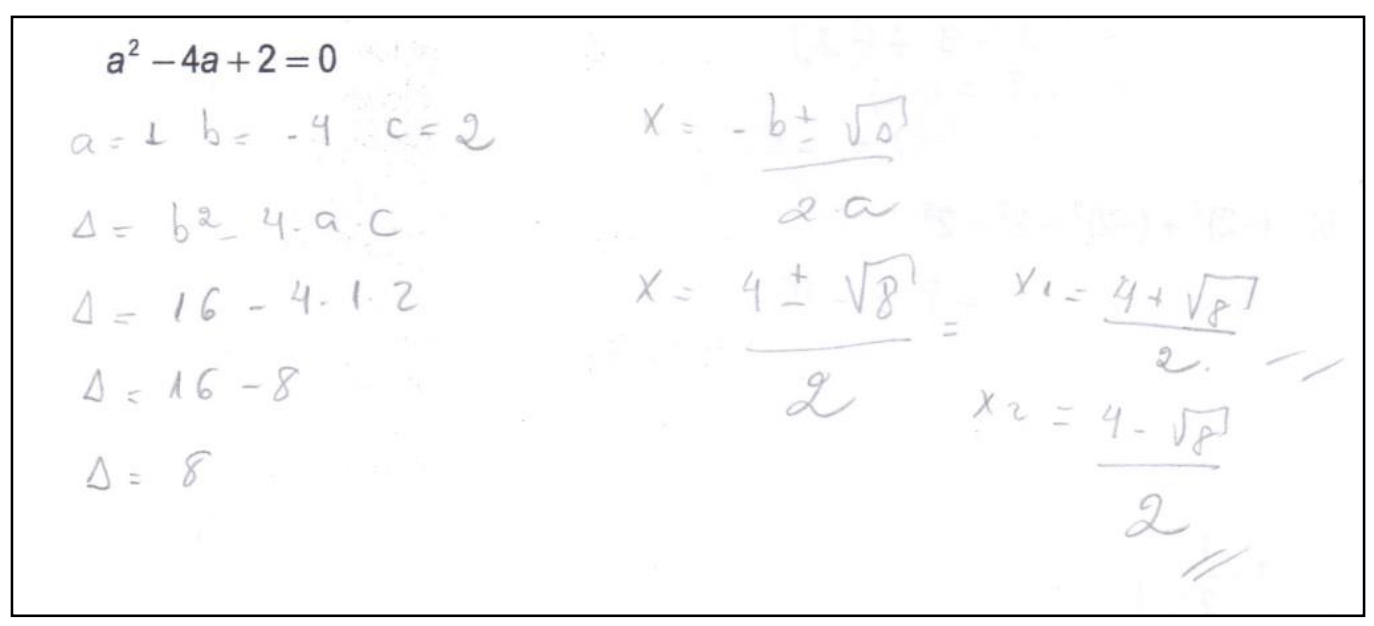

Figura 20 - Resolução de aluno

Novamente aparece aqui um erro conceitual em que o aluno não fatorou o 8, não podendo assim simplificar o radical nem a fração. Vale ressaltar que todos os seus cálculos estão corretos, mas o exercício está incompleto. Esse é um tipo de erro devido a uma aprendizagem prévia deficiente ou até mesmo a uma rigidez no raciocínio. 


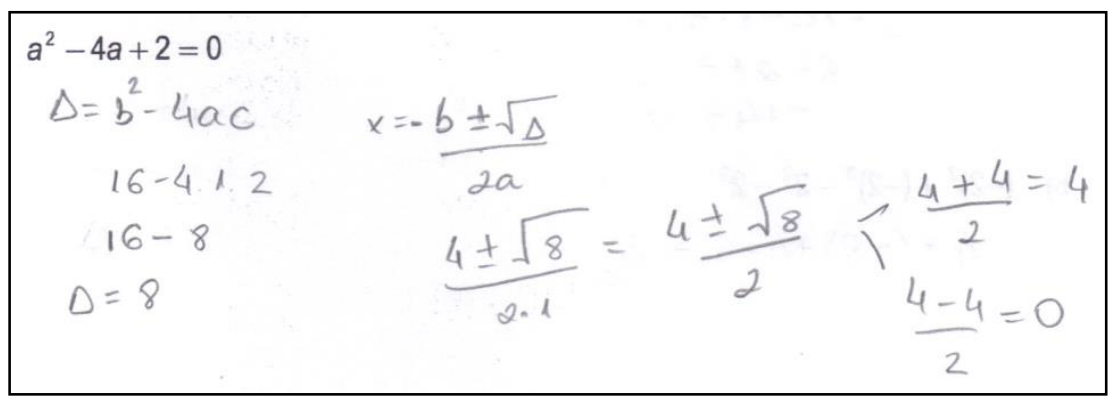

Figura 21 - Resolução de aluno

Um erro muito comum é dividir o número do qual se está querendo extrair a raiz quadrada por 2. Dessa forma, o aluno chegou a $\sqrt{8}=8 \div 2=4$. Não se pode descartar a possibilidade de ter sido um caso de falta de atenção, mas acredito que esse erro pode ser devido a uma rigidez de raciocínio ou a uma aprendizagem prévia deficiente.

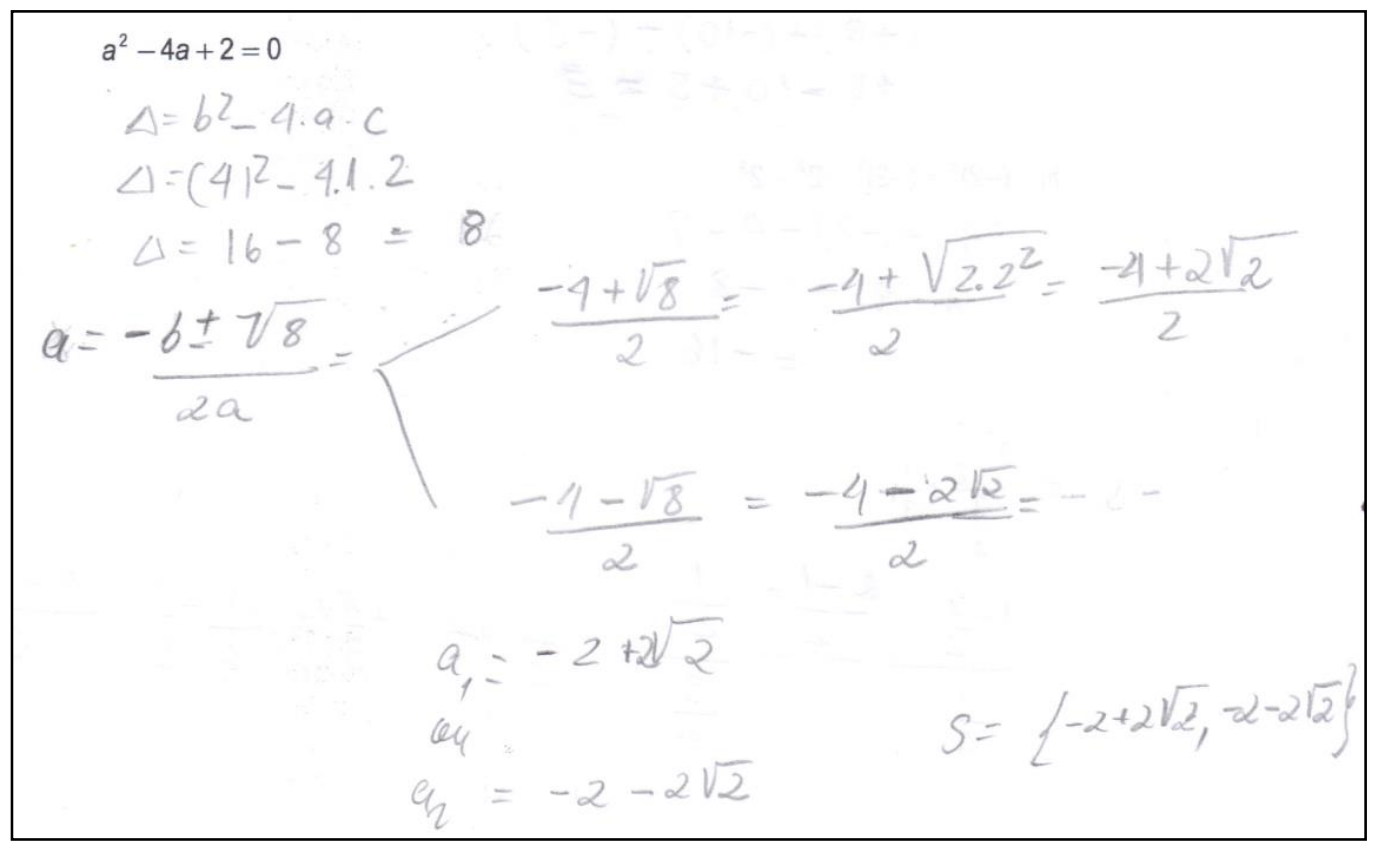

Figura 22 - Resolução de aluno

E aqui aparece o erro com maior percentual: a simplificação de frações. Este aluno simplificou apenas uma parte do numerador com o denominador. Isso ocorre porque o aluno não compreendeu o fato de que só podemos "cortar" uma parte da fração se modificarmos o numerador e o denominador ao mesmo tempo. Este é o conceito de frações equivalentes que já foi mencionado anteriormente. Pode-se classificar este erro como devido a uma aprendizagem prévia deficiente, a uma generalização de regras ou até a um cálculo incorreto. 


\section{Análise por nível de escolaridade}

Analisando o desempenho dos alunos $3^{\circ}$ ano do Ensino Médio e do $1^{\circ}$ ano da Faculdade separadamente, não foi percebida nenhuma peculiaridade que justificasse uma análise detalhada em separado. Dessa forma, a seguir, serão apenas apresentados os gráficos comparativos.

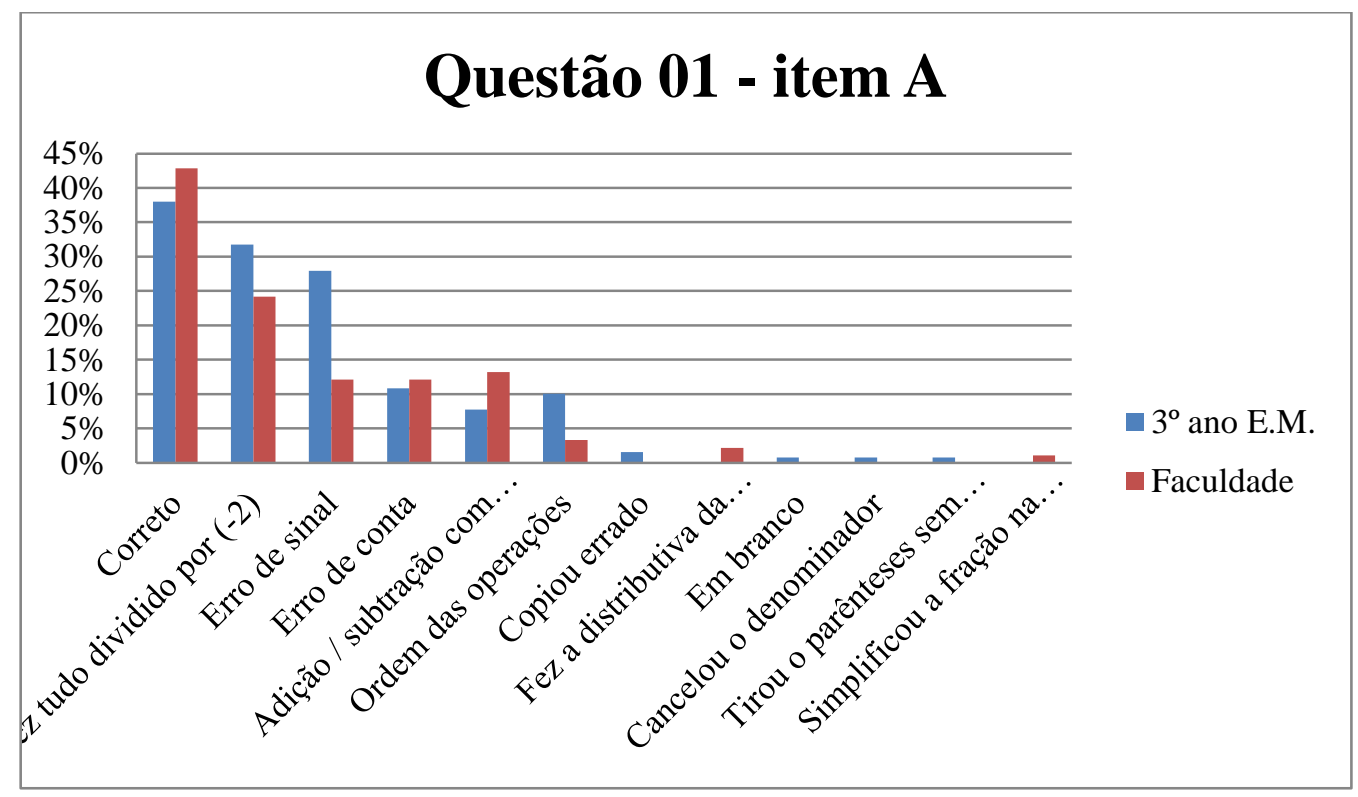

Gráfico 7 - Resolução da Questão 1A separada por nível de escolaridade

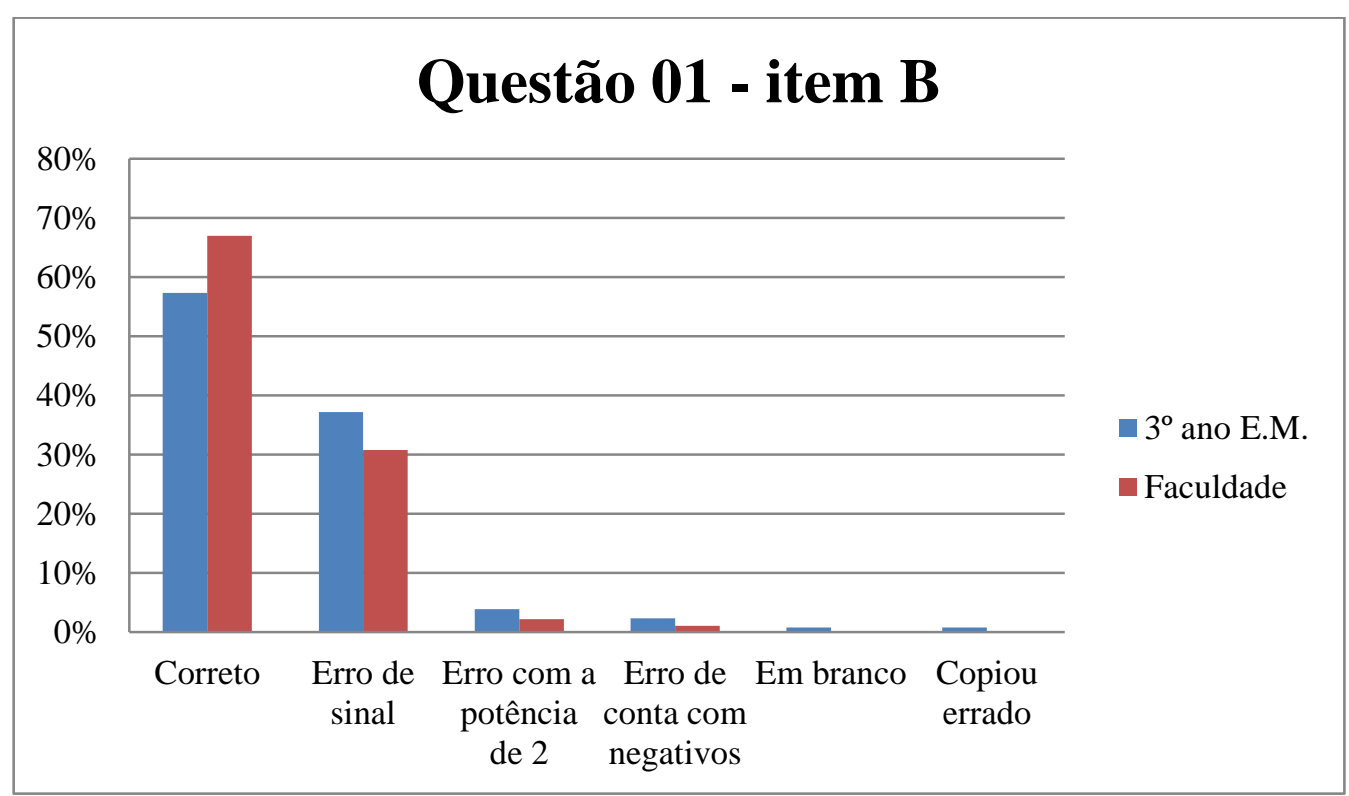

Gráfico 8 - Resolução da Questão 1B separada por nível de escolaridade 


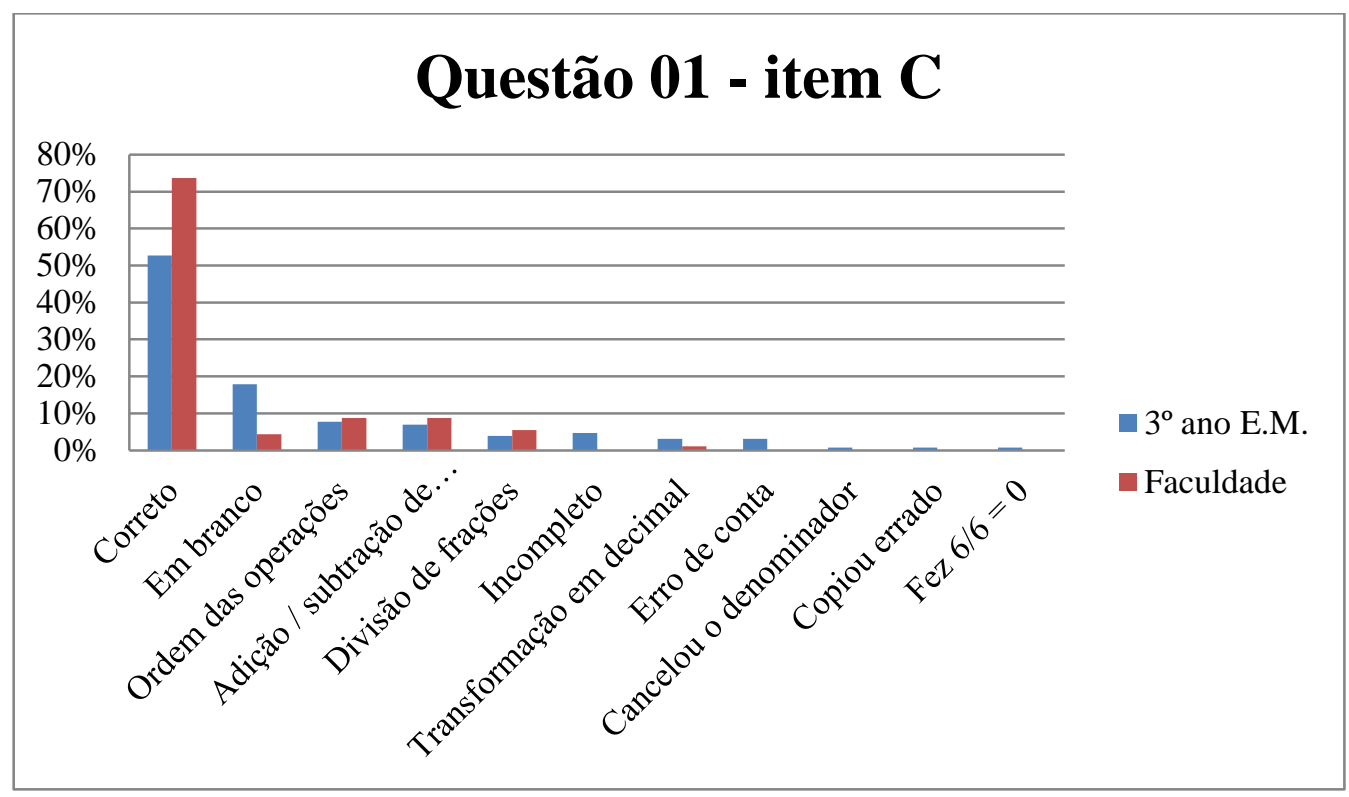

Gráfico 9 - Resolução da Questão 1C separada por nível de escolaridade

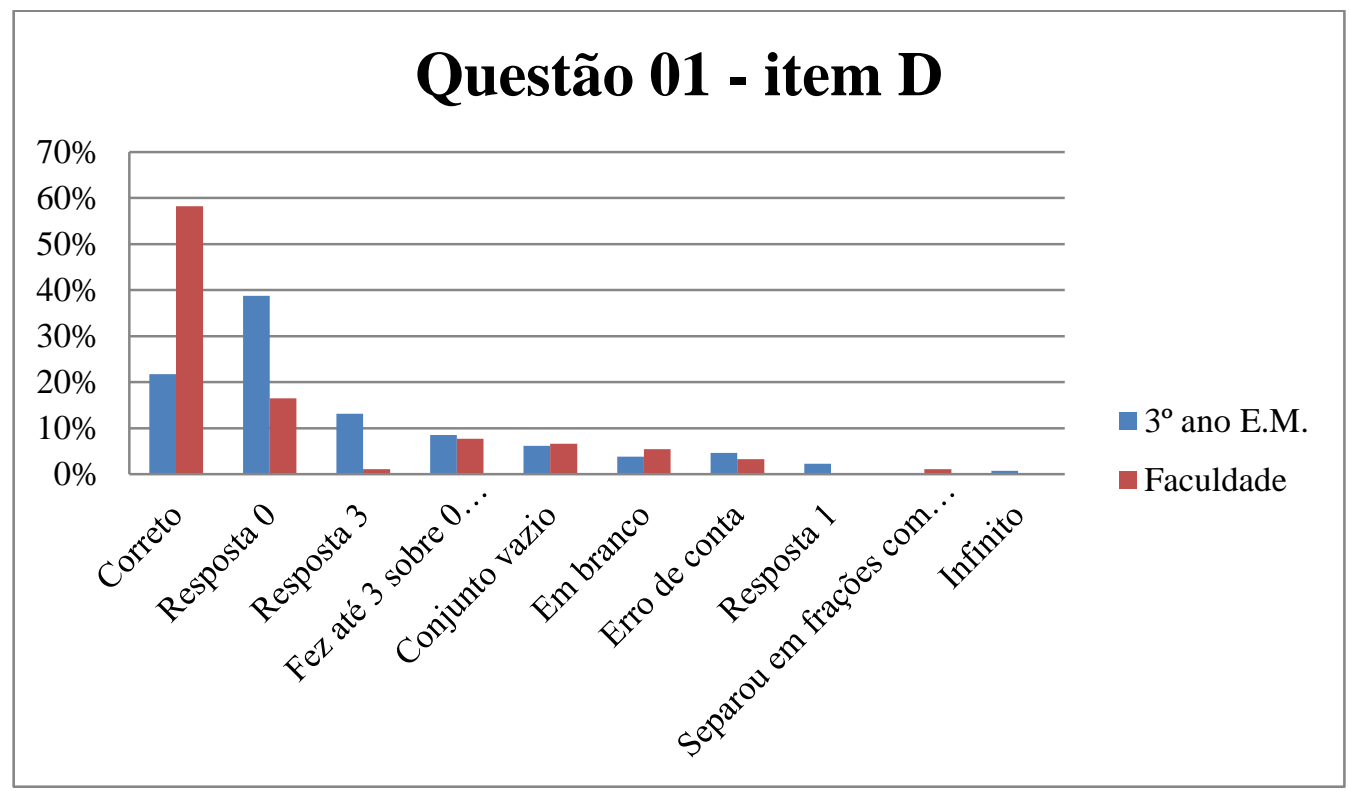

Gráfico 10 - Resolução da Questão 1D separada por nível de escolaridade 


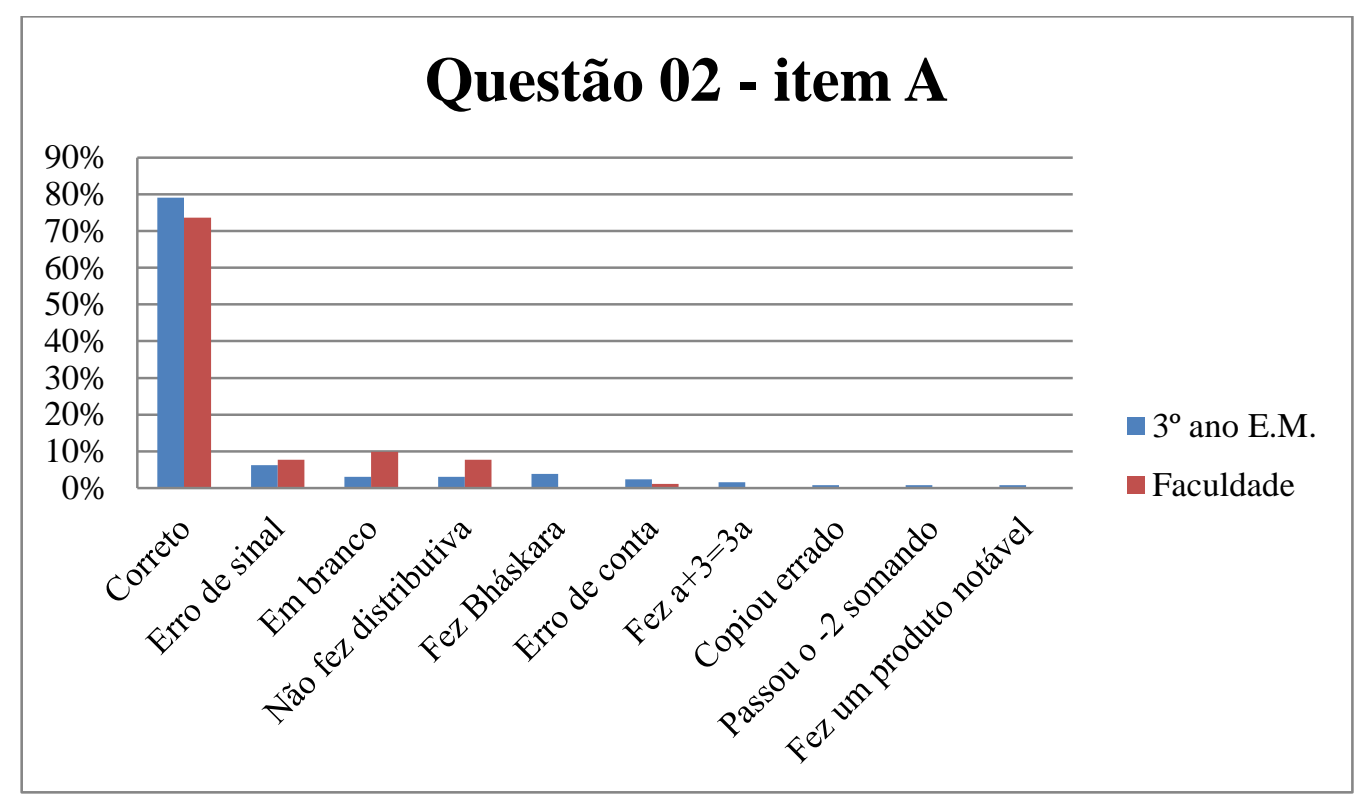

Gráfico 11 - Resolução da Questão 2A separada por nível de escolaridade

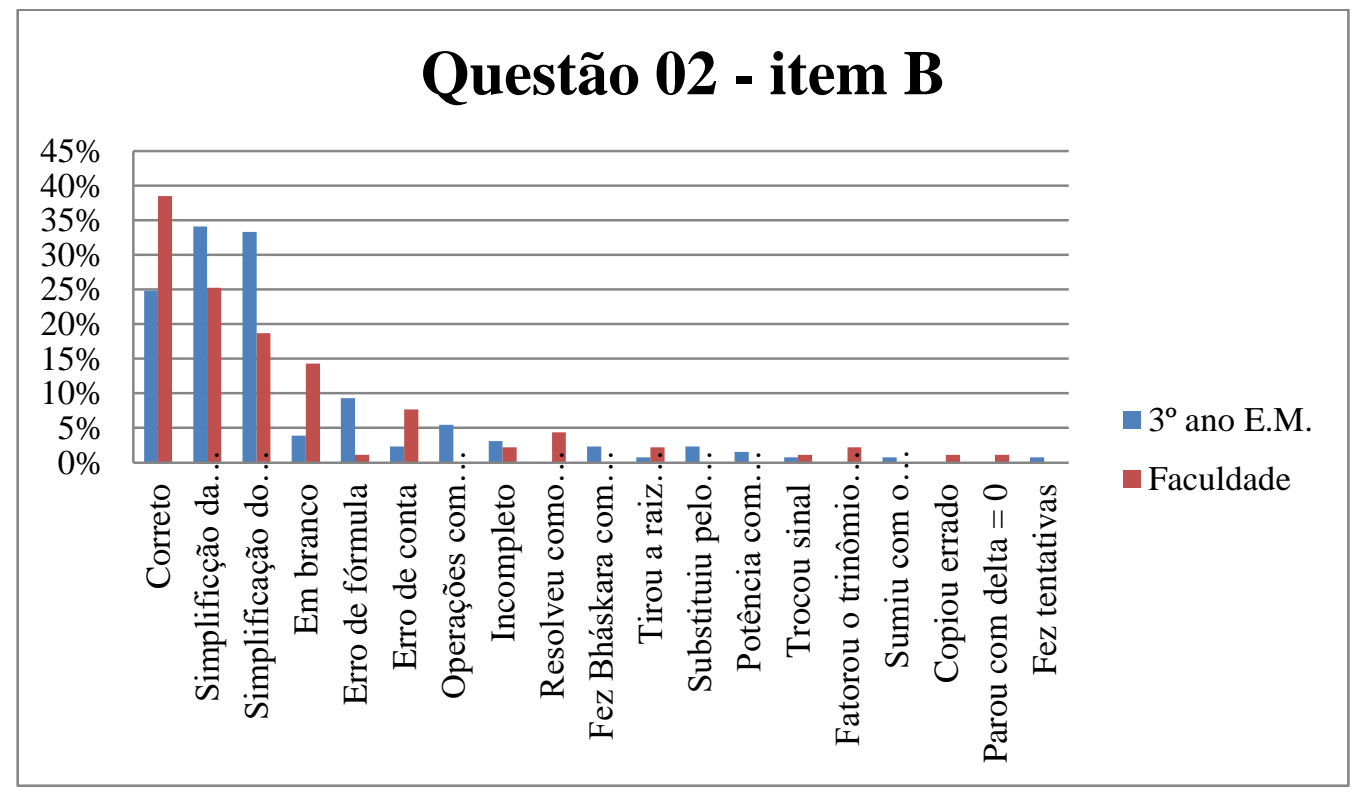

Gráfico 12 - Resolução da Questão 2B separada por nível de escolaridade 


\subsection{CONCLUSÕES PARCIAIS}

Analisando as resoluções dos alunos, além das tabelas e dos gráficos anteriores, pode-se perceber que certos erros ocorreram com mais frequência. A seguir foram destacados alguns deles.

- Quando os alunos aprendem a trabalhar com números inteiros, seu professor ensina que "menos com menos dá mais" na multiplicação e na divisão; porém, os alunos simplesmente decoram a regra de sinais. Sendo assim, generalizam para qualquer operação a ideia de que sinais iguais levam a um resultado positivo e sinais diferentes, a um resultado negativo. Esse erro pôde ser observado em alguns itens do questionário.

- Os alunos tendem a aplicar um conceito novo em qualquer contexto. Muitas vezes aplicam a regra de multiplicação de frações para a divisão, aplicam a distributiva para a soma, para a subtração ou até mesmo para a divisão.

- Muitas vezes os alunos aplicam regras erradas ou não têm bem formado o conceito necessário para a resolução. Foram identificados erros de simplificação de fração, na resolução pela fórmula de Bháskara, de operações com radicais e suas simplificações.

- Alguns erros conceituais também foram encontrados, por exemplo, na divisão por zero, na resolução de potências e radicais, nas operações com fração, entre outros vistos.

- Quando os alunos aprendem a lidar com equações, é comum a frase "passa pro outro lado e troca de sinal"; porém, com esse procedimento, alguns esquecem o conceito de igualdade envolvido e acabam aplicando tal regra para todas as operações que fazem durante a resolução. Esse erro foi exemplificado em alguns itens.

Com essa análise, é possível inferir que os erros com maior frequência são relativos à generalização de regras, à aprendizagem prévia deficiente e à dificuldade na linguagem, conforme classificação mencionada na página 37. 


\section{SEGUNDO QUESTIONÁRIO}

Após análise dos resultados do primeiro questionário, optei por montar um segundo questionário envolvendo apenas equações. Tal tema foi escolhido por ser possível trabalhar com alguns conteúdos mencionados no questionário anterior, como regra de sinais, operações com frações, ordem das operações, entre outros.

Um grande problema do tema em questão é o fato de o aluno achar que sabe. Quando isto acontece, o aluno não consegue identificar o problema e, muito menos, resolvê-lo. Além dos dados obtidos pelo questionário inicial, duas situações específicas que aconteceram em minhas aulas, envolvendo excelentes alunos, me motivaram a escolher esse tema.

SITUAÇÃO 1: Ao corrigir um exercício na lousa, em uma aula sobre equações fracionárias, após calcular o mínimo múltiplo comum e garantir que os denominadores não seriam nulos, eu falei que podíamos "cancelar os denominadores" e trabalhar somente com os valores do numerador. Para eles, isso já é uma prática antiga de operações com frações vista desde o $7^{\circ}$ ano do Ensino Fundamental II. Todos os outros alunos não hesitaram nesse passo da resolução, porém um aluno me perguntou "por que podemos cortar os denominadores?".

SITUAÇÃO 2: Em uma aula de Geometria Analítica sobre equações da reta, necessitávamos de transformar a equação reduzida da reta $y=\frac{x}{2}+1$ para a forma geral, enquanto resolvíamos um exercício. Quando perguntei a eles o que fazer, um aluno deu a ideia de "passar o 2 para o outro lado, multiplicando".

Essas duas situações relatadas são exemplos de situações nas quais os alunos apenas reproduzem esquemas que foram feitos pelo professor, sem, na realidade, saberem o que estão fazendo. Dei-me conta de que se esses dois alunos, que têm facilidade em Matemática, estavam com dúvidas oriundas do conceito de equações, muitos outros podiam estar com a mesma dificuldade e não perceber ou não demonstrar.

Diante disso, o segundo questionário foi elaborado com o objetivo específico de analisar as dificuldades manifestadas durante a resolução de equações, conteúdo este que é utilizado como ferramenta durante todo o Ensino Médio. Segundo Freitas (2002), os alunos manipulam equações 
de forma mecânica e muitas vezes o método ensinado mascara o real significado das operações. Dessa forma, o erro é uma supergeneralização do procedimento de transposição de termos.

A aplicação do questionário foi feita em junho do ano letivo de 2015 , a cinquenta e sete alunos do $3^{\circ}$ ano do Ensino Médio do período noturno de uma escola estadual do Estado de São Paulo. É importante citar que eu não conhecia os alunos nem o trabalho desenvolvido na escola. Gostaria de observar ainda que, apesar de o questionário ter sido aplicado em junho, os alunos estavam sem aula desde março, devido à greve dos professores. Sendo assim, o questionário foi aplicado na primeira semana de aula após o término da greve.

O questionário proposto foi respondido durante uma aula de 45 minutos. Os alunos selecionados para este segundo questionário foram diferentes daqueles que responderam o primeiro, mas foram os mesmos que participaram da etapa de entrevistas, de forma que seus resultados puderam ser comparados e analisados posteriormente. 


\subsection{ANÁLISE}

\section{Descrição das questões}

O único exercício do questionário tinha por enunciado: "Resolver as equações a seguir" e era composto por oito itens:

- Item A: $3(x+1)=x-1$;

- Item B: $x-3=5(x+1)$;

- Item C: $9-4 x=3-2 x+4$.

Estes itens foram selecionados com o objetivo de analisar o domínio dos alunos em relação à propriedade distributiva, além de observar como o aluno trabalha com operações envolvendo números inteiros. Alguns procedimentos como "menos com menos dá mais" e "passa pro outro lado e troca o sinal" foram fundamentais para suas composições. A intenção era investigar quão presente eles são nas resoluções dos alunos.

Observe-se que, no segundo item, era muito provável que o aluno chegasse em $-4 x=8$. Dessa forma desejava-se averiguar se a regra de "passa pro outro lado e troca o sinal" também iria valer para $\mathrm{o}-4$.

- Item D: $\frac{2 x+1}{3}-\frac{3 x+2}{5}=2$;

- Item E: $x+1=\frac{x-2}{4}$;

- Item F: $x+1=\frac{x}{2}+4$.

Estes itens foram selecionados com o objetivo de explorar o domínio dos alunos em relação à operações com números racionais. $\mathrm{O}$ sinal de menos antes da segunda fração no primeiro item foi propositalmente colocado para ver se os alunos iriam utilizá-lo somente para o primeiro número do numerador ou para ambos. Também queria verificar como os alunos iriam trabalhar com o número 2 no segundo membro da igualdade.

O item E induzia o aluno a "passar o 4 pro outro lado multiplicando", o que não gera erro em sua resolução. Já no item F "passar o 2 pro outro lado multiplicando" não pode ser feito. 
- Item $\mathrm{G}:(x-3)(x+1)=0$;

- Item H: $(x+1)(x+2)=6$.

Estes itens foram selecionados com o objetivo de analisar qual técnica de resolução os alunos iriam utilizar, se fazer a distributiva e aplicar a resolução por soma e produto ou por Bháskara, se haveria alguém que dividiria a resolução do item $\mathrm{G}$ em duas equações, fazendo cada fator igual a zero, e ainda se essa resolução com divisão em dois casos apareceria no item $\mathrm{H}$, o que não pode ser feito.

\section{Análise geral por questão}

A seguir, de acordo com a classificação já mencionada anteriormente, foi feita uma análise dos erros cometidos pelos alunos e obtiveram-se os seguintes resultados para cada item já citado: 
Item A: Resolver $3(x+1)=x-1$.

\begin{tabular}{lc}
\hline \multicolumn{2}{c}{ Item A } \\
\hline Correto & $45,6 \%$ \\
\hline Mudou de lado e não inverteu a operação & $17,5 \%$ \\
\hline Em branco & $8,8 \%$ \\
\hline Não manteve o sinal de menos no 4 & $7,0 \%$ \\
\hline Não fez a distributiva do 3 & $5,3 \%$ \\
\hline Sumiu com a igualdade & $5,3 \%$ \\
Somou termos com x e sem x & $5,3 \%$ \\
\hline Apenas fez a distributiva & $3,5 \%$ \\
\hline Passou número pra um lado e letra pro outro sem fazer a distributiva & $3,5 \%$ \\
\hline Divisão de números inteiros & $3,5 \%$ \\
\hline Não passou o 2 dividindo & $3,5 \%$ \\
\hline Inverteu o sinal de quem passa multiplicando & $1,8 \%$ \\
Trocou o sinal sem mudar o lado & $1,8 \%$ \\
Passou o 2 dividindo e trocando o sinal & $1,8 \%$ \\
\hline Duas igualdades & $1,8 \%$ \\
\hline Multiplicou por -1 apenas um lado da equação & $1,8 \%$ \\
\hline Raciocínio difícil de compreender & $1,8 \%$ \\
\hline
\end{tabular}

Tabela 7 - Resolução do Item A

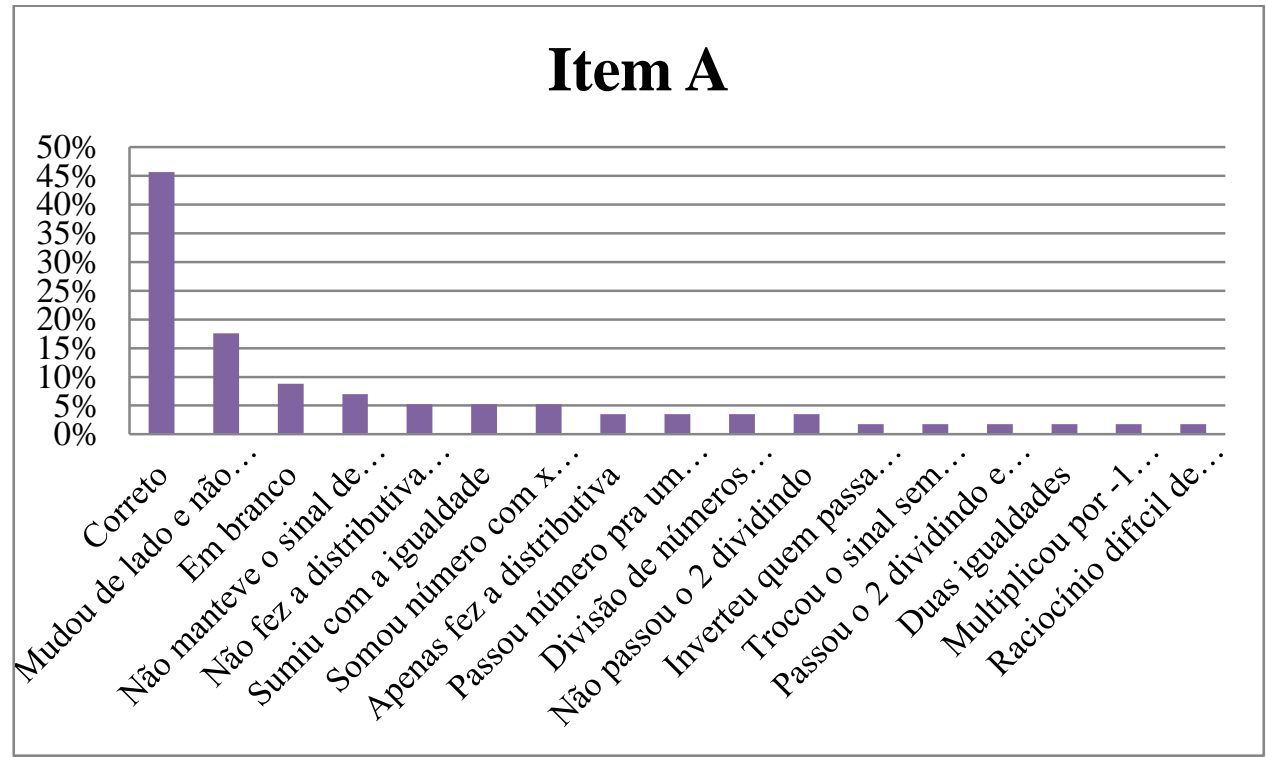

Gráfico 13 - Resolução do Item A

Apesar do grande percentual de acerto, o erro mais frequente nesse item foi relacionado à regra "muda de lado e troca o sinal", em que os alunos mudaram os números para o outro lado e 
não inverteram a operação ou inverteram erradamente. As operações com números inteiros e as técnicas de resolução de equações também ficaram presentes nos erros. Observem-se alguns casos específicos.

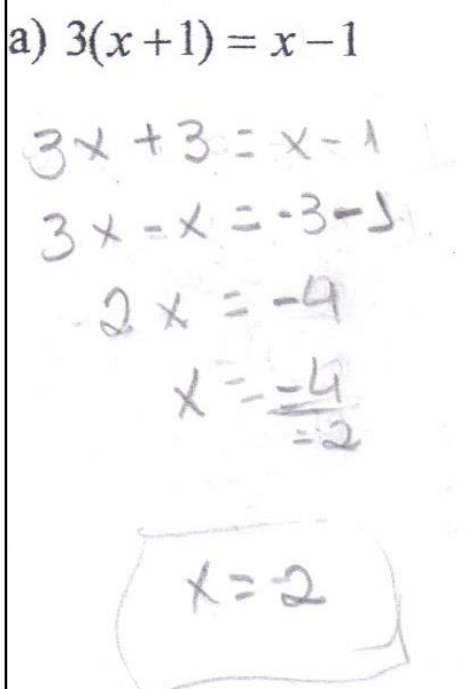

Figura 23 - Resolução de aluno

Neste primeiro exemplo pode-se ver a regra generalizada, pois o aluno passou o 2 para o outro lado, invertendo o sinal, não somente a operação. Trata-se, então de um possível erro devido à generalização de regras.

$$
\begin{aligned}
& 3(x+1)=x-1 \\
& 3 x+3=x-1 \\
& 3 x+x=3-1 \\
& 4 x-2 \\
& 2 x
\end{aligned}
$$

Figura 24 - Resolução de aluno

Neste caso, o aluno fez operações juntando termos com $x$ e termos sem $x$, além de ter sumido com o sinal de igual, desfazendo assim a igualdade e a ideia de equação. Pode-se notar também que o aluno não inverteu a operação ao trocar os termos de lado na segunda linha de 
resolução. Acredito que se trata de erros devidos a uma dificuldade na linguagem e uma aprendizagem prévia deficiente.

$$
\begin{aligned}
& 3(x+1)=x-1 \\
& 3 x+3=x-1 \\
& 3 x-x=-3-1 \\
& 2 x=-4 \\
& x=\frac{2}{4}=-2
\end{aligned}
$$

Figura 25 - Resolução de aluno

Neste exemplo, o aluno inverteu os termos na montagem da fração. Pode-se notar que tanto o conceito de fração como o de equação não ficaram bem esclarecidos. Trata-se então de um erro devido a uma dificuldade na linguagem e a uma aprendizagem prévia deficiente.

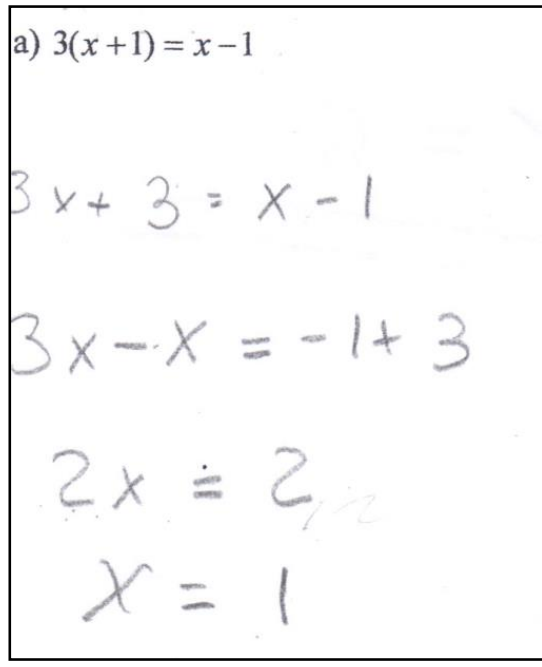

Figura 26 - Resolução de aluno

Neste último caso, o aluno trocou o sinal do $x$, mas não trocou o do 3 quando mudou os termos de lado. Pode se tratar de um erro devido ao cálculo incorreto ou à aprendizagem prévia deficiente. 
Item B: Resolver $x-3=5(x+1)$.

\begin{tabular}{lc}
\hline \multicolumn{2}{c}{ Item B } \\
\hline Correto & $29,8 \%$ \\
\hline Em branco & $17,5 \%$ \\
Adição e subtração com números inteiros & $15,8 \%$ \\
Mudou de lado e não inverteu a operação & $15,8 \%$ \\
Não fez a distributiva do 5 & $8,8 \%$ \\
Dividiu por 4 positivo & $7,0 \%$ \\
Sumiu com a igualdade & $7,0 \%$ \\
Divisão com números inteiros & $3,5 \%$ \\
Somou termo com x e sem x & $1,8 \%$ \\
Passou número pra um lado e letra pro outro sem fazer a distributiva & $1,8 \%$ \\
Dividiu por 4 negativo e manteve o menos no x & $1,8 \%$ \\
Raciocínio difícil de compreender & $1,8 \%$ \\
Não passou o 4 dividindo & $1,8 \%$ \\
Errou na distributiva do 5 & $1,8 \%$ \\
\hline
\end{tabular}

Tabela 8 - Resolução do Item B

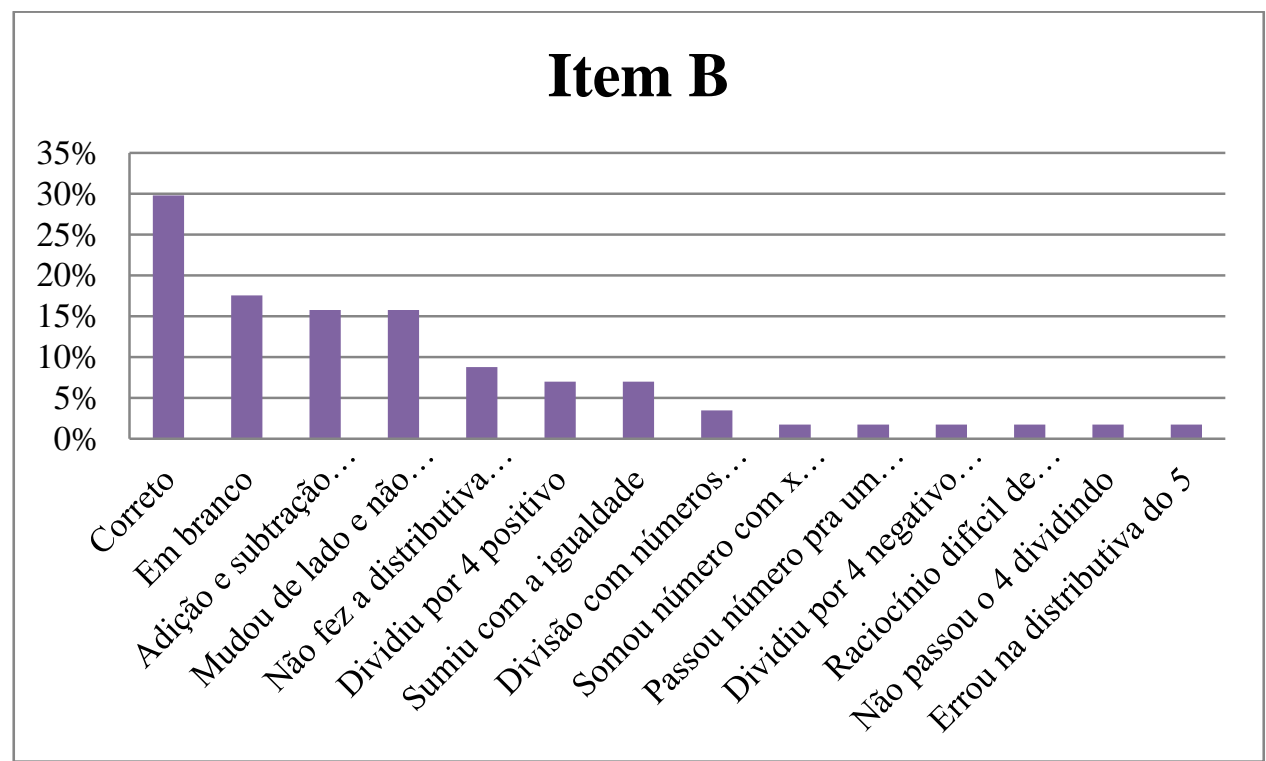

Gráfico 14 - Resolução do Item B

Neste item, apresentam-se os mesmo erros que no item anterior, nota-se uma dificuldade com o conceito de equação e as regrinhas decoradas erradamente, assim como operações com números inteiros e racionais. Vejam-se alguns exemplos. 


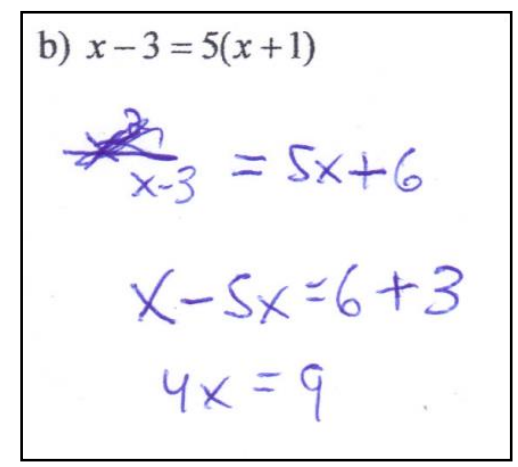

Figura 27 - Resolução de aluno

Neste caso, ao fazer a distributiva, o aluno, somou $5+1=6$, em vez de fazer $5 \cdot 1=5$, mostrando um conceito equivocado de distributiva. No passo final, mostra também uma dúvida com relação a operações com números inteiros, fazendo $x-5 x=4 x$. Esse aluno, então, cometeu erros devido a uma aprendizagem prévia deficiente.

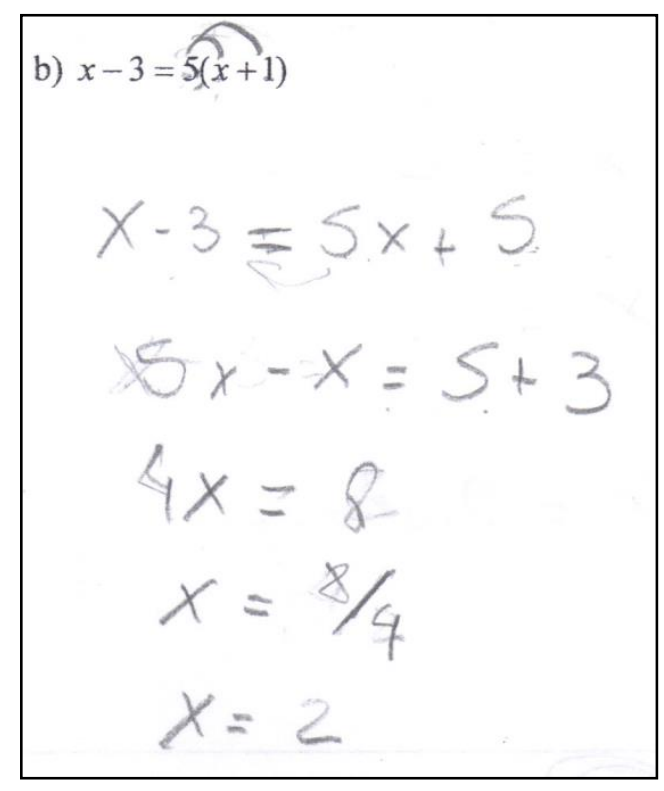

Figura 28 - Resolução de aluno

Aqui, ao escrever $5 x-x$, o aluno pode ter se esquecido de trocar os sinais ao manipular a equação ou pode ter escrito da forma como lhe convinha, colocando o maior número antes do menor na subtração. Trata-se de um erro devido ao cálculo incorreto ou à aprendizagem prévia deficiente. 


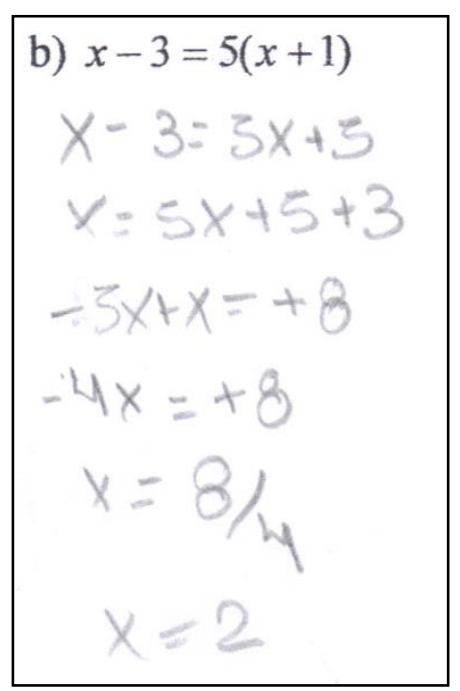

Figura 29 - Resolução de aluno

No último exemplo, tem-se um clássico erro devido a uma generalização de regras, em que o aluno generaliza o uso do procedimento de "passa pro outro lado e inverte o sinal", pois aplica isso para a divisão e multiplicação. 
Item C: Resolver $9-4 x=3-2 x+4$.

\begin{tabular}{lc}
\hline \multicolumn{2}{c}{ Item C } \\
\hline Correto & $43,9 \%$ \\
Em branco & $22,8 \%$ \\
Mudou de lado e não inverteu a operação & $14,0 \%$ \\
Sumiu com a igualdade & $8,8 \%$ \\
Adição e subtração com números inteiros & $7,0 \%$ \\
Fez 2 / 2 = 0 & $3,5 \%$ \\
Passou o 2 dividindo e trocando o sinal & $3,5 \%$ \\
Somou termo com x e sem x & $1,8 \%$ \\
Raciocínio difícil de compreender & $1,8 \%$ \\
Sumiu com o 9 & $1,8 \%$ \\
\hline
\end{tabular}

Tabela 9 - Resolução do Item C

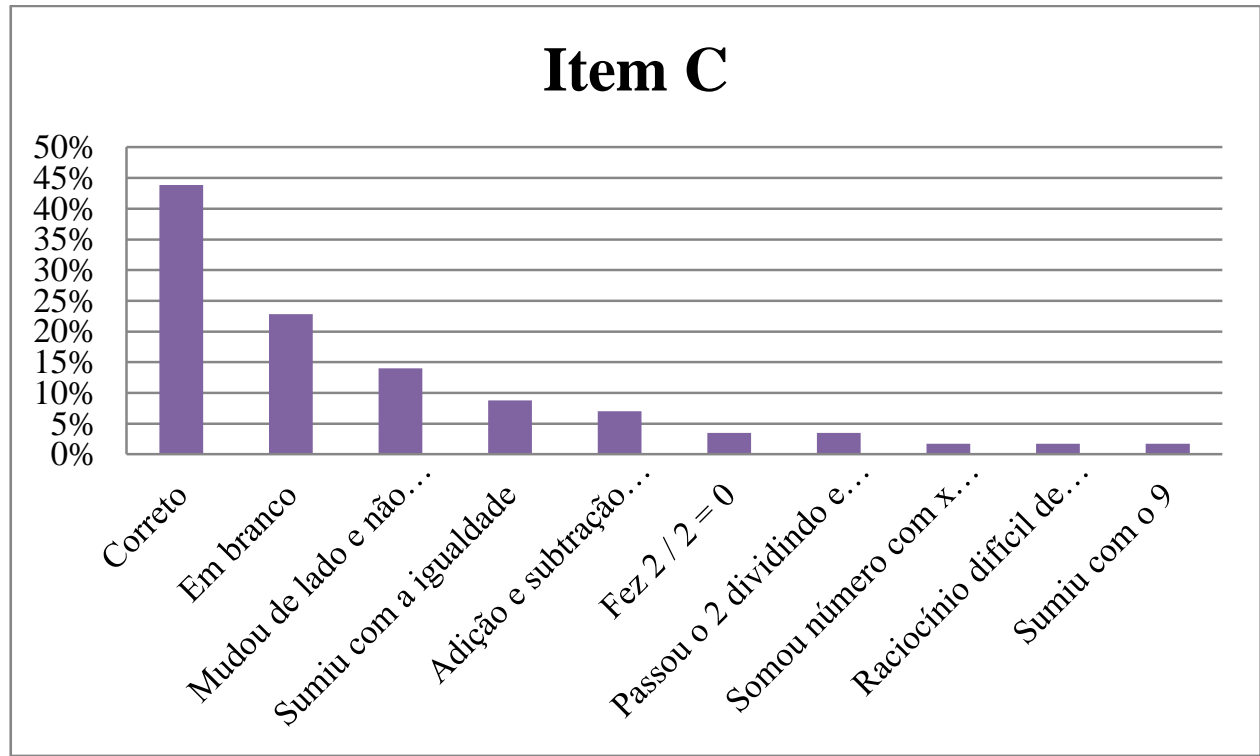

Gráfico 15 - Resolução do Item C

Temos mais uma vez os mesmos erros dos itens anteriores. Vamos ver dois casos específicos.

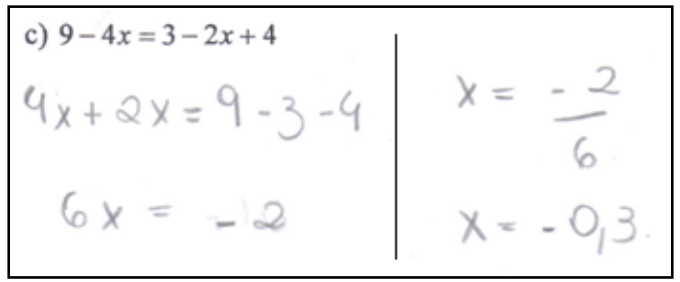

Figura 30 - Resolução de aluno 
Neste primeiro, temos uma pequena confusão com relação aos sinais, pois o aluno passou o $4 x$ para o outro lado, mas escreveu do mesmo, a mesma coisa aconteceu com o 3 e o 4 . Dessa forma, o único sinal que ficou errado foi o do $2 x$. Podemos ter, então, um erro devido ao cálculo incorreto ou à aprendizagem prévia deficiente.

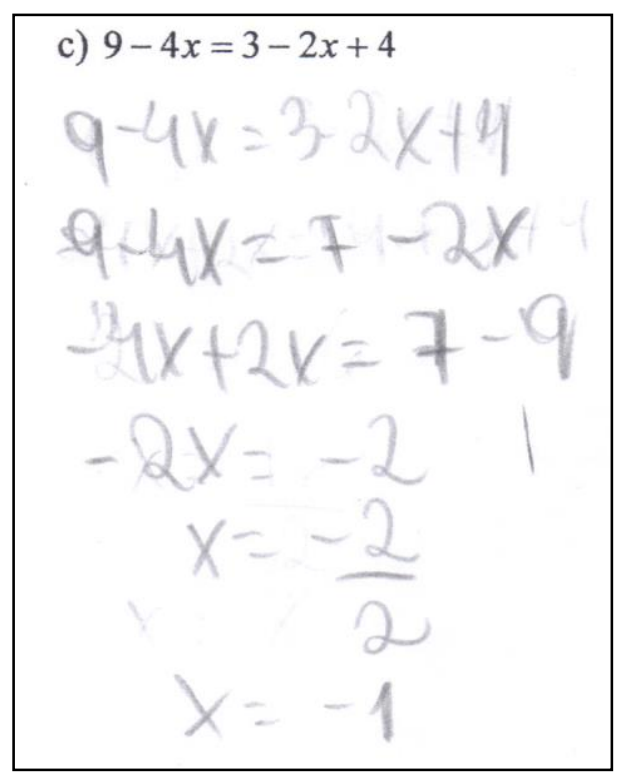

Figura 31 - Resolução de aluno

E, neste último caso, temos, mais uma vez, o procedimento utilizado de maneira errada, quando o - 2 passa para o outro lado invertendo o sinal e também a operação. Novamente, um erro devido à generalização de regras. 
Item D: Resolver $\frac{2 x+1}{3}-\frac{3 x+2}{5}=2$.

\begin{tabular}{lc}
\hline \multicolumn{2}{c}{ Item D } \\
\hline Em branco & $49,1 \%$ \\
Sinal de menos na frente da fração & $35,1 \%$ \\
\hline Não calculou o MMC & $14,0 \%$ \\
Somou termo com x e sem x & $7,0 \%$ \\
Calculou o MMC e não modificou o numerador & $7,0 \%$ \\
Não calculou o MMC e fez a conta com os numeradores & $5,3 \%$ \\
Sumiu com a igualdade & $3,5 \%$ \\
Mudou de lado e não inverteu a operação & $3,5 \%$ \\
Correto & $1,8 \%$ \\
Raciocínio difícil de compreender & $1,8 \%$ \\
\hline
\end{tabular}

Tabela 10 - Resolução do Item D

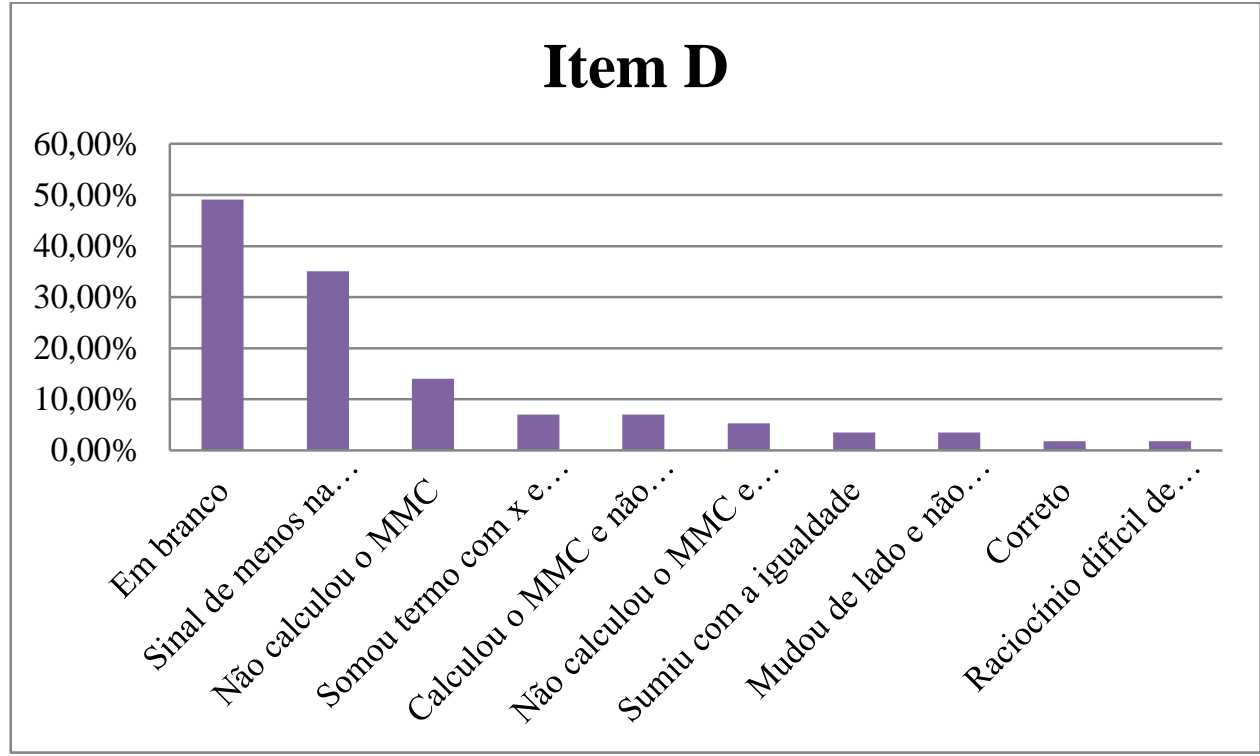

Gráfico 16 - Resolução do Item D

Quando se trata de frações, muitos alunos têm certa tendência a achar que o exercício ficará mais difícil. Sendo assim, o índice de desistência aumenta e é possível escutar frases do tipo "fração é impossível” ou "com fração eu não sei fazer". Dos 57 alunos que responderam a esse questionário, apenas um aluno acertou a questão por completo, enquanto que 28 deixaram em branco. Dos demais alunos, apareceram alguns problemas com as operações com frações, com o MMC (mínimo múltiplo comum), com o sinal de menos na frente da segunda fração e ainda apareceram os mesmos erros já citados nos três itens anteriores. Vamos observar alguns 
casos específicos.

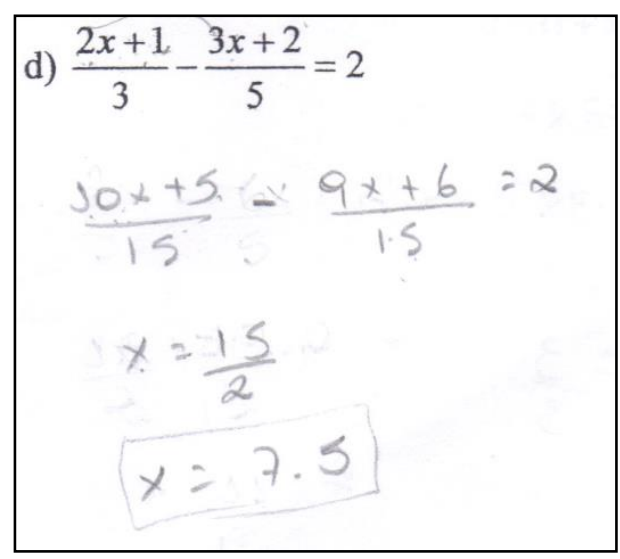

Figura 32- Resolução de aluno

Nesse caso, o raciocínio do aluno é bem confuso. Na primeira passagem, ele calcula o MMC e iguala os denominadores apenas do lado esquerdo da igualdade e, na segunda passagem, ele aparentemente esquece o numerador e tenta usar o 15 e o 2 para chegar a algum resultado viável. Essa situação pode ser típica do contrato didático, pois o aluno entende que o problema deve ter uma resposta e, como ele não sabe calcular, ele faz alguma conta qualquer para fornecer um resultado final. Esse tipo de erro pode ser devido à aprendizagem prévia deficiente ou rigidez de raciocínio.

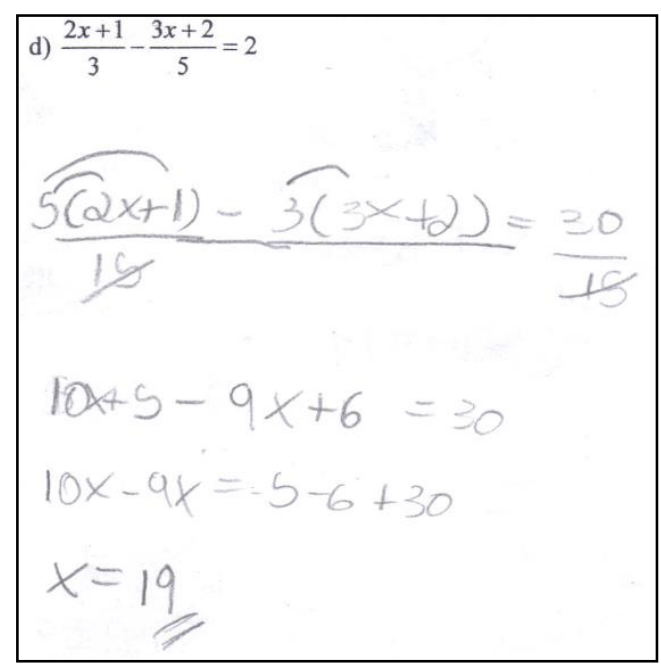

Figura 33 - Resolução de aluno

Já nesse caso, o aluno calcula o MMC para igualar os denominadores dos dois lados e faz o procedimento correto para alterar o numerador; porém, ao fazer a distributiva do -3 , ele deixa 
o sinal de menos somente para o primeiro resultado. Esse erro pode ser uma simples falta de atenção ou até mesmo um conceito mal formado; sendo assim, podemos ter um erro devido ao cálculo incorreto ou à aprendizagem prévia deficiente.

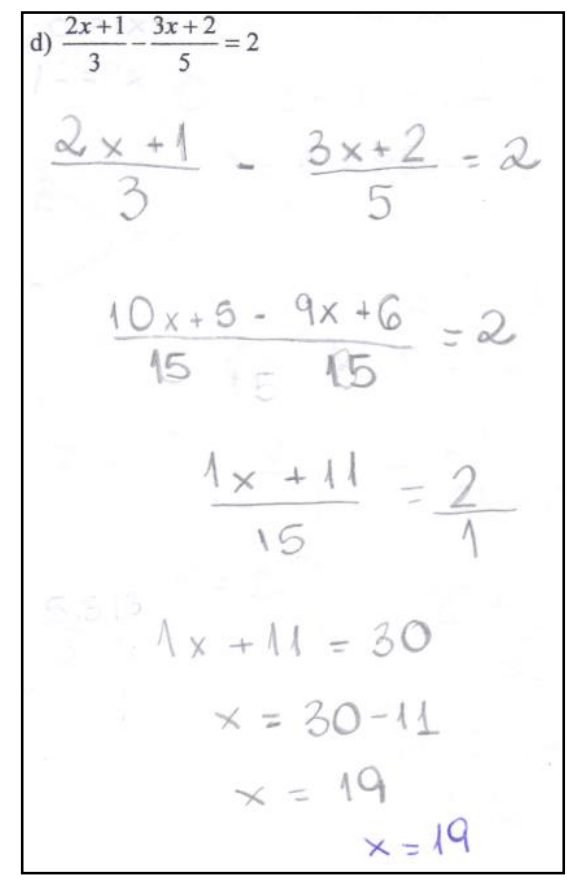

Figura 34 - Resolução de aluno

Este outro exemplo é bem similar ao anterior, porém o aluno não calcula o MMC da parte direita da igualdade e deixa para multiplicar em cruz no final, utilizando, assim, uma propriedade de frações equivalentes. Porém, também não houve a distributiva do sinal de menos, levando a um resultado incorreto. Esse erro, como o anterior, pode ser devido ao cálculo incorreto ou à aprendizagem prévia deficiente. 


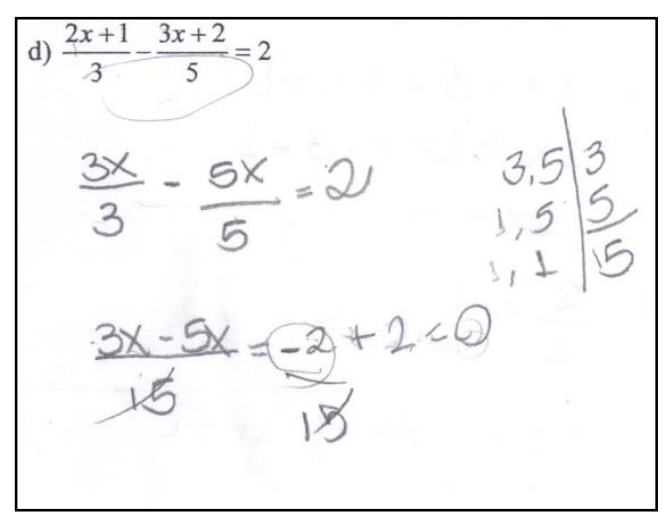

Figura 35 - Resolução de aluno

Nesse caso o aluno fez operações juntando termos com $x$ e termos sem $x$ no numerador, em seguida faz $3 x-5 x=-2$, coloca o 2 que estava no passo anterior, corta o 15 e chega a um resultado igual a zero. Esse tipo de erro possivelmente é ligado a uma aprendizagem prévia deficiente, pois o conceito de frações equivalentes não parece ter sido absorvido.

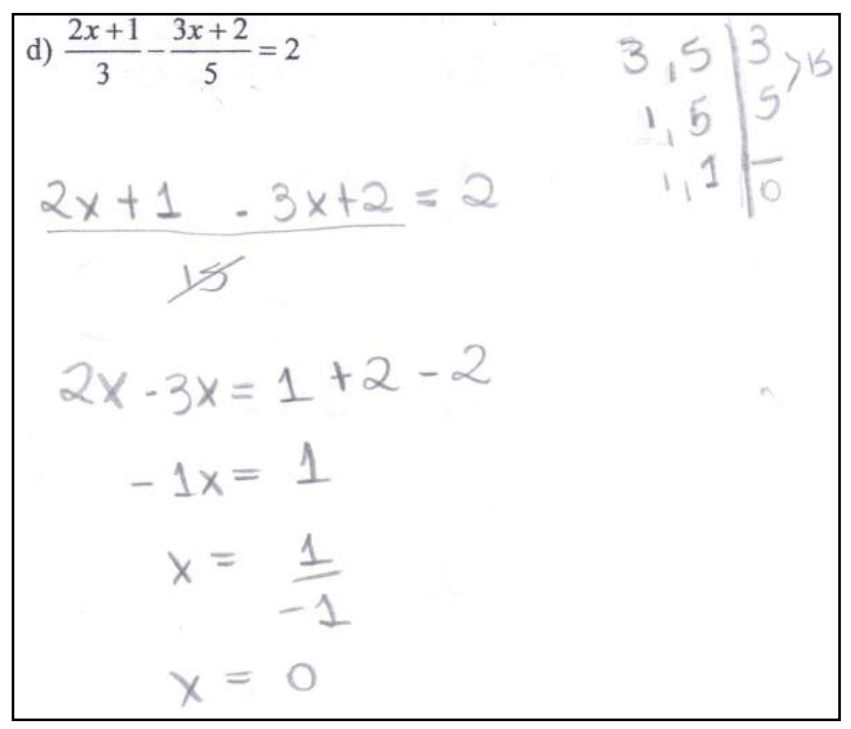

Figura 36 - Resolução de aluno

Nesse último caso, o aluno apenas colocou o 15 como denominador sem nem alterar o numerador do lado esquerdo. Em seguida cancelou o denominador, cortando apenas o 15 do lado esquerdo. E, no último passo, ele faz uma divisão equivocada. Trata-se, então de erros devidos a uma aprendizagem prévia deficiente. 
Item E: Resolver $x+1=\frac{x-2}{4}$.

\begin{tabular}{lc}
\hline \multicolumn{2}{c}{ Item E } \\
\hline Em branco & $63,2 \%$ \\
\hline Correto & $10,5 \%$ \\
Mudou de lado e não inverteu a operação & $8,8 \%$ \\
Não fez a distributiva do 4 & $5,3 \%$ \\
Sumiu com a igualdade & $5,3 \%$ \\
Passou o 3 dividindo e trocando o sinal & $5,3 \%$ \\
Calculou o MMC e não modificou o numerador & $3,5 \%$ \\
Passou o 4 multiplicando e trocando o sinal & $3,5 \%$ \\
Somar termo com x e sem x & $1,8 \%$ \\
\hline
\end{tabular}

Tabela 11 - Resolução do Item E

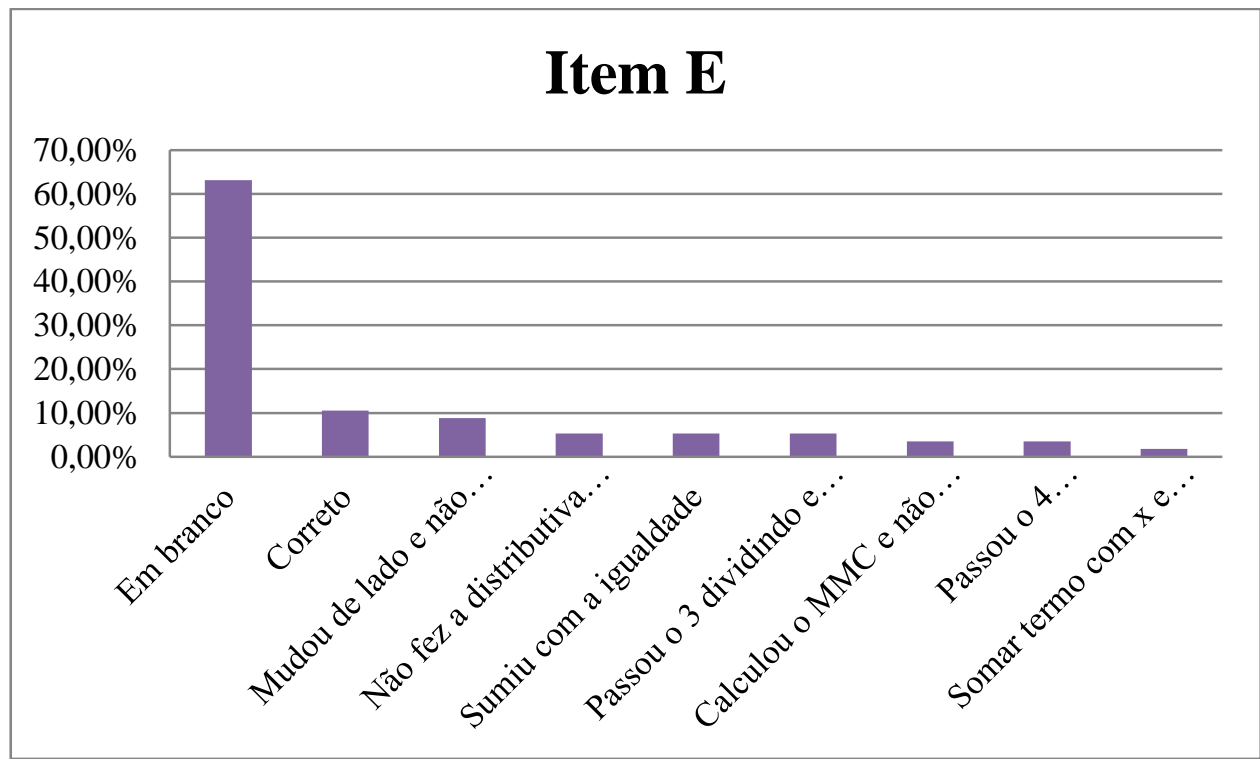

Gráfico 17 - Resolução do Item E

A partir deste item há um grande percentual de questões em branco. Alguns porque desistiram pelo cansaço, outros pelo nível de dificuldade e há ainda aqueles que não conseguiram fazer por conta do tempo.

Fora os questionários em branco, algumas das mesmas dificuldades foram encontradas nesse item. Vamos ver a seguir alguns exemplos. 


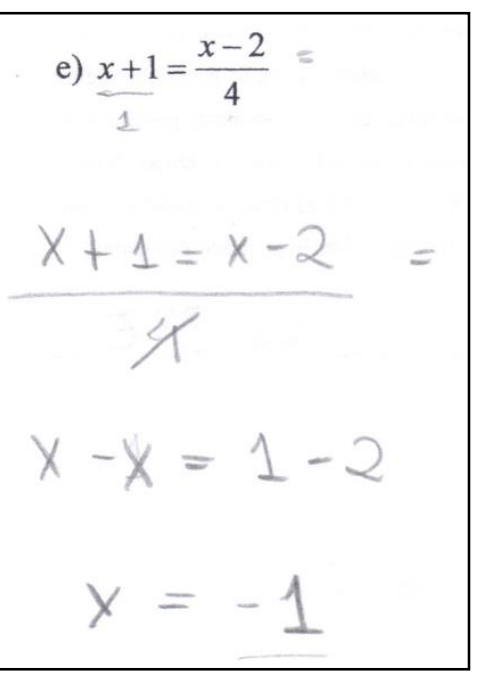

Figura 37 - Resolução de aluno

Nesse exemplo, o aluno calculou o MMC e igualou os denominadores, sem alterar os numeradores, mostrando uma deficiência com o conceito de frações equivalentes. Trata-se, portanto, de um erro devido a uma aprendizagem prévia deficiente. Ele também fez $x-x=x$, mostrando uma dificuldade na linguagem.

e) $x+1=\frac{x-2}{4}$

$x+1=\frac{-2 x}{4}$

$x+2 x=1+9$

$3 x=3$

$$
\frac{3 x}{3}
$$

Figura 38 - Resolução de aluno

Nesse caso, o aluno começou o raciocínio transformando uma subtração em 
multiplicação, fazendo $x-2=-2 x$, não inverteu as operações para trocar os termos de lado e também não chegou a um resultado final. Nesse caso, é difícil analisar o erro do aluno, mas podese dizer que há um pouco de erro devido a uma aprendizagem prévia deficiente e talvez a uma rigidez de raciocínio.

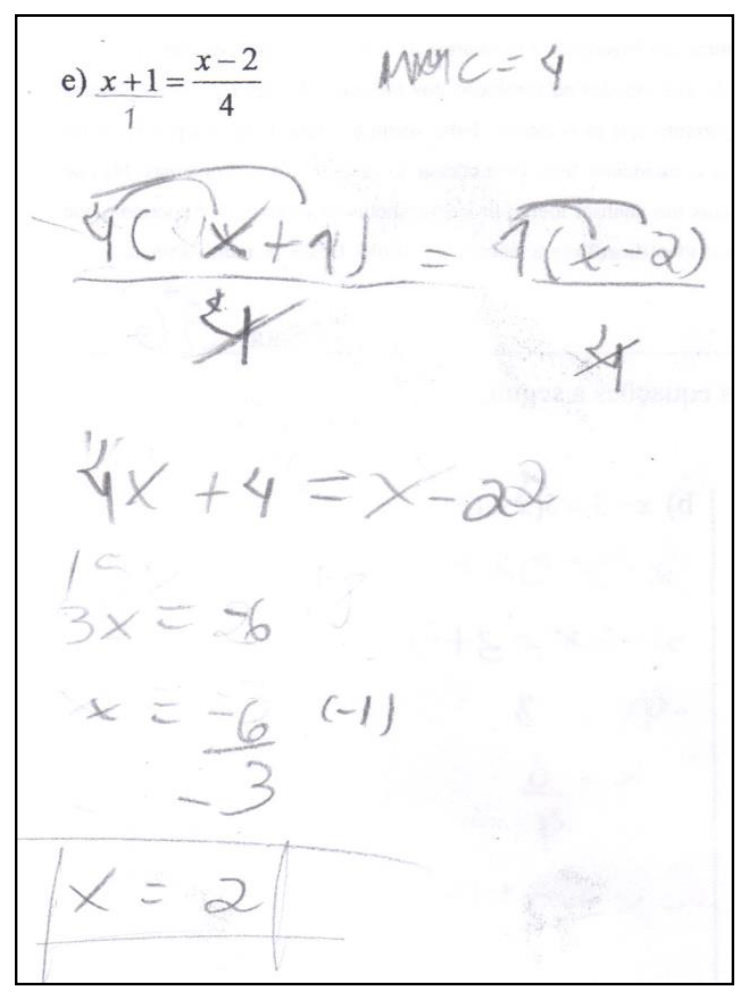

Figura 39 - Resolução de aluno

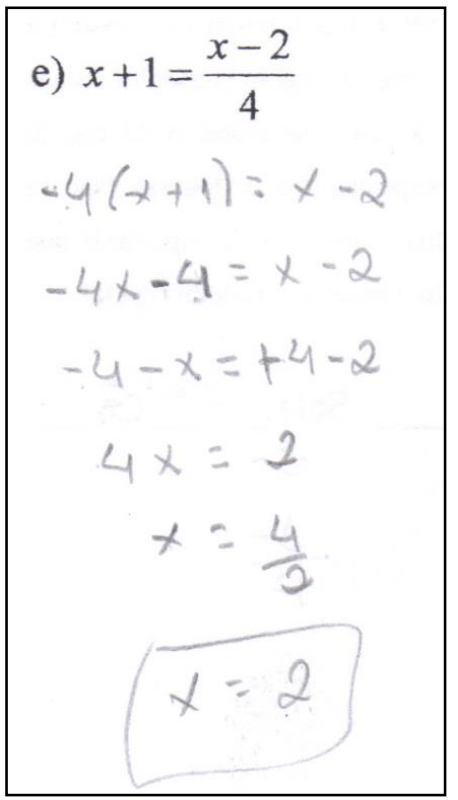

Figura 40 - Resolução de aluno

Nesses dois casos, o erro foi ao aplicar o procedimento do "passa pro outro lado trocando o sinal". No exemplo da esquerda, o aluno passou o 3 dividindo como - 3 e, no exemplo da direita, o aluno passou o 4 multiplicando como - 4 . Em ambos os casos, somente a operação deveria ter sido invertida, não o sinal. Mais uma amostra de erros devidos a uma generalização de regras.

No último caso, que segue, o aluno passou o 4 multiplicando; porém ele só multiplicou o $x$, sem fazer a distributiva. Além disso, quando passou o 3 dividindo, ele inverteu o sinal como em outros exemplos já mostrados. Sendo assim, acredito se tratar de erros devidos à generalização de regras e à aprendizagem prévia deficiente. 


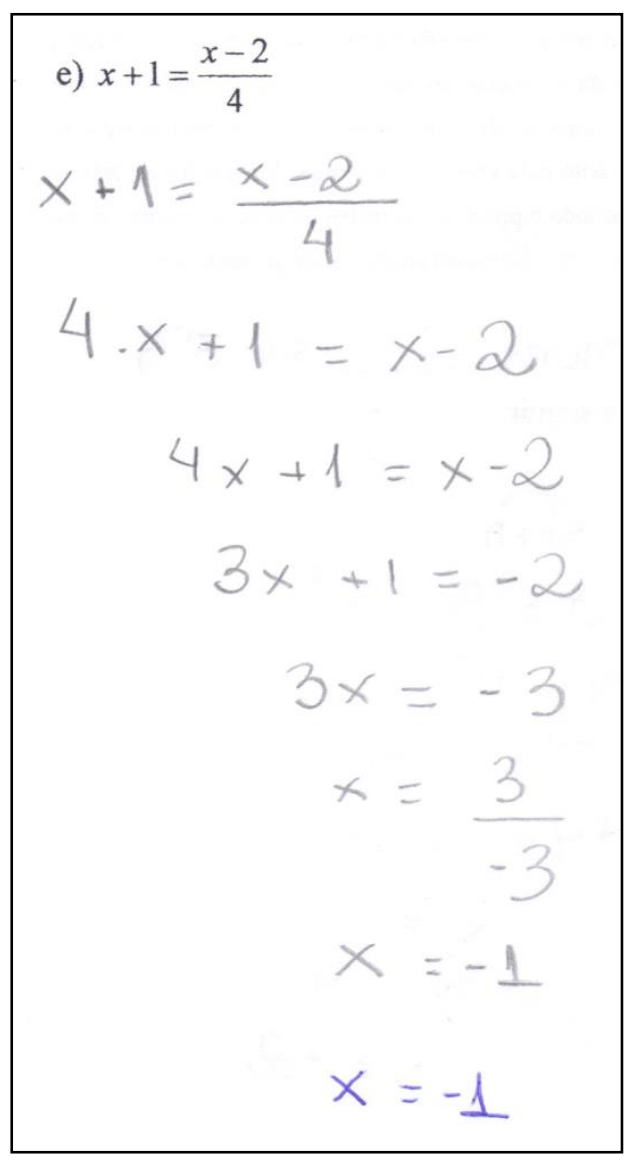

Figura 41 - Resolução de aluno

Esse item induzia o aluno a passar o 4 para o outro lado multiplicando, pois o item seguinte servia para testar se o aluno sabia como aplicar corretamente esse processo, lembrando de igualar todos os denominadores ou multiplicar toda a equação pelo mesmo fator. 
Item F: Resolver $x+1=\frac{x}{2}+4$.

\begin{tabular}{lc}
\hline \multicolumn{2}{c}{ Item F } \\
\hline Em branco & $63,2 \%$ \\
\hline Não calculou o MMC & $19,3 \%$ \\
Correto & $7,0 \%$ \\
Calculou o MMC e não modificou o numerador & $3,5 \%$ \\
Sumiu com a igualdade & $3,5 \%$ \\
Mudou de lado e não inverteu a operação & $3,5 \%$ \\
Não fez a distributiva do 2 & $3,5 \%$ \\
Passou o 2 multiplicando e trocando o sinal & $1,8 \%$ \\
Não tirou o MMC & $1,8 \%$ \\
\hline
\end{tabular}

Tabela 12 - Resolução do Item F

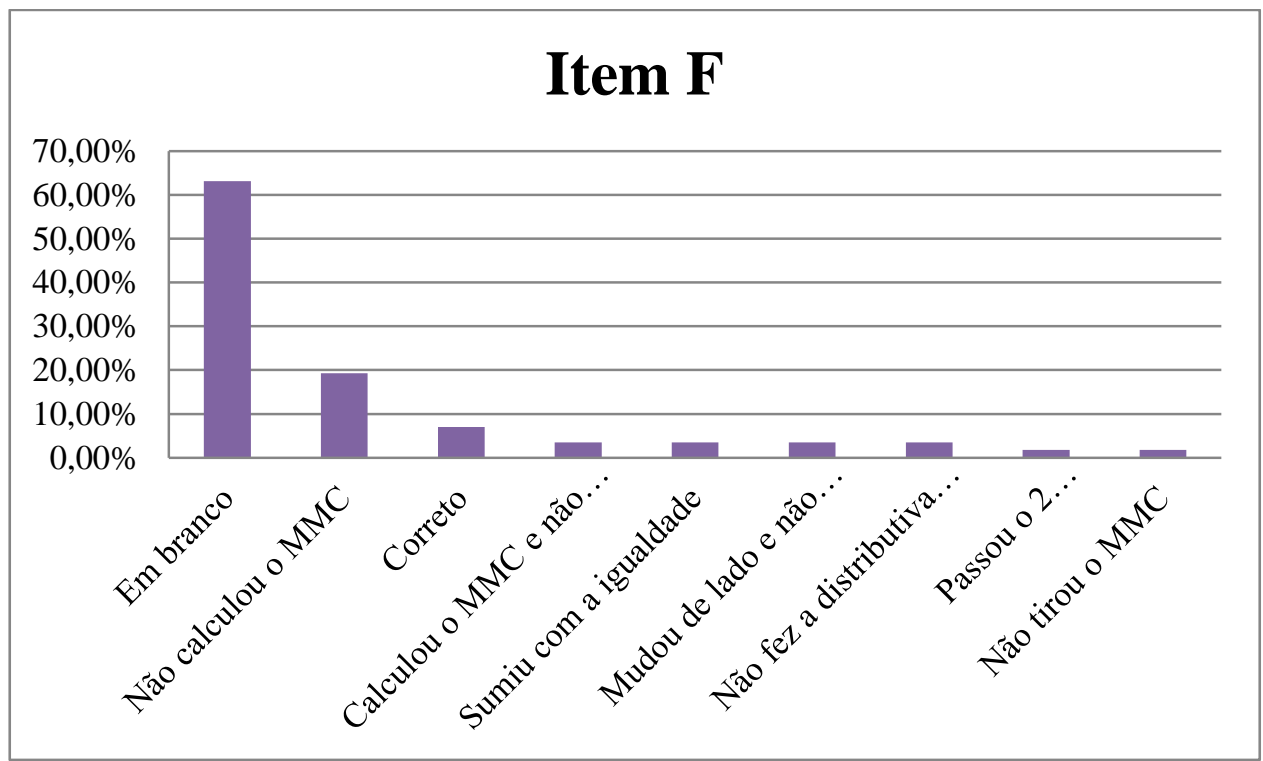

Gráfico 18 - Resolução do Item F

Os erros nesse item são bem similares aos erros dos dois itens anteriores. Alguns alunos passaram o 2 para o outro lado multiplicando, outros inverteram o sinal ao mudar o número de lado, outros fizeram conta com termos com $x$ e outros sem $x$, outros somaram os denominadores e ainda houve aqueles que não fizeram a distributiva. Com exceção dos questionários em branco, a maioria dos alunos não calculou o MMC para igualar os denominadores a 4, o que seria equivalente a "passar o 2 pro outro lado multiplicando". Nesse caso, claramente os alunos generalizaram a regra possível para o item anterior, se tratando de um erro devido à generalização de regras. 
Observem-se a seguir os exemplos desse item.

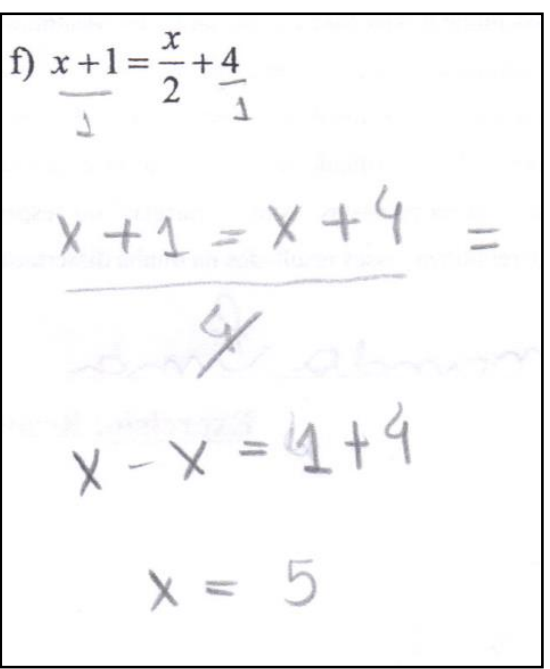

Figura 42 - Resolução de aluno

$$
\text { f) } \begin{aligned}
x+1 & \left.=\frac{x}{2}+4\right) \cdot z \\
-2(x+1) & =x+4 \\
-2 x-2 & =x+4 \\
-2 x-x & =+2+4 \\
2 x & =\frac{6}{6} \\
x & =\frac{6}{2} \\
x & =3
\end{aligned}
$$
f) $x+1=\frac{x}{2}+4$

$21+1+1+1+4$

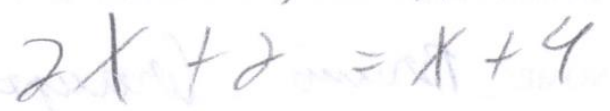

$2 x+x=2+4$

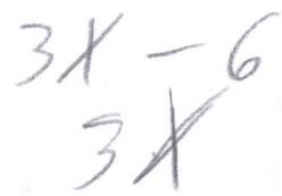

Figura 43 - Resolução de aluno

$$
\text { f) } \begin{aligned}
x+1=\frac{x}{2}+\frac{4}{1} & \\
x+1=\frac{x}{2}+4 & \\
2 x+1 & =x+4 \\
x+1 & =4 \\
x & =3 \\
x & =3
\end{aligned}
$$


Item G: Resolver $(x-3)(x+1)=0$.

\begin{tabular}{lc}
\hline \multicolumn{2}{c}{ Item G } \\
\hline Em branco & $59,6 \%$ \\
Correto & $8,8 \%$ \\
\hline Parou ao achar a equação de 2o grau & $5,3 \%$ \\
\hline Fez x vezes x igual a x & $5,3 \%$ \\
\hline Tirou os parênteses sem aplicar a distributiva & $3,5 \%$ \\
\hline Parou ao achar o valor de delta & $3,5 \%$ \\
\hline Errou a fórmula de Bháskara & $3,5 \%$ \\
Multiplicação com números inteiros no delta & $1,8 \%$ \\
\hline Inverteu a ordem do a, b, e c do Bháskara & $1,8 \%$ \\
Encontrou apenas um valor de x & $1,8 \%$ \\
Raciocínio difícil de compreender & $1,8 \%$ \\
\hline Adição e subtração de números inteiros & $1,8 \%$ \\
\hline Juntou x ${ }^{2}$ com x & $1,8 \%$ \\
Mudou o sinal do - b no Bháskara em cada um dos casos & $1,8 \%$ \\
\hline
\end{tabular}

Tabela 13 - Resolução do Item G

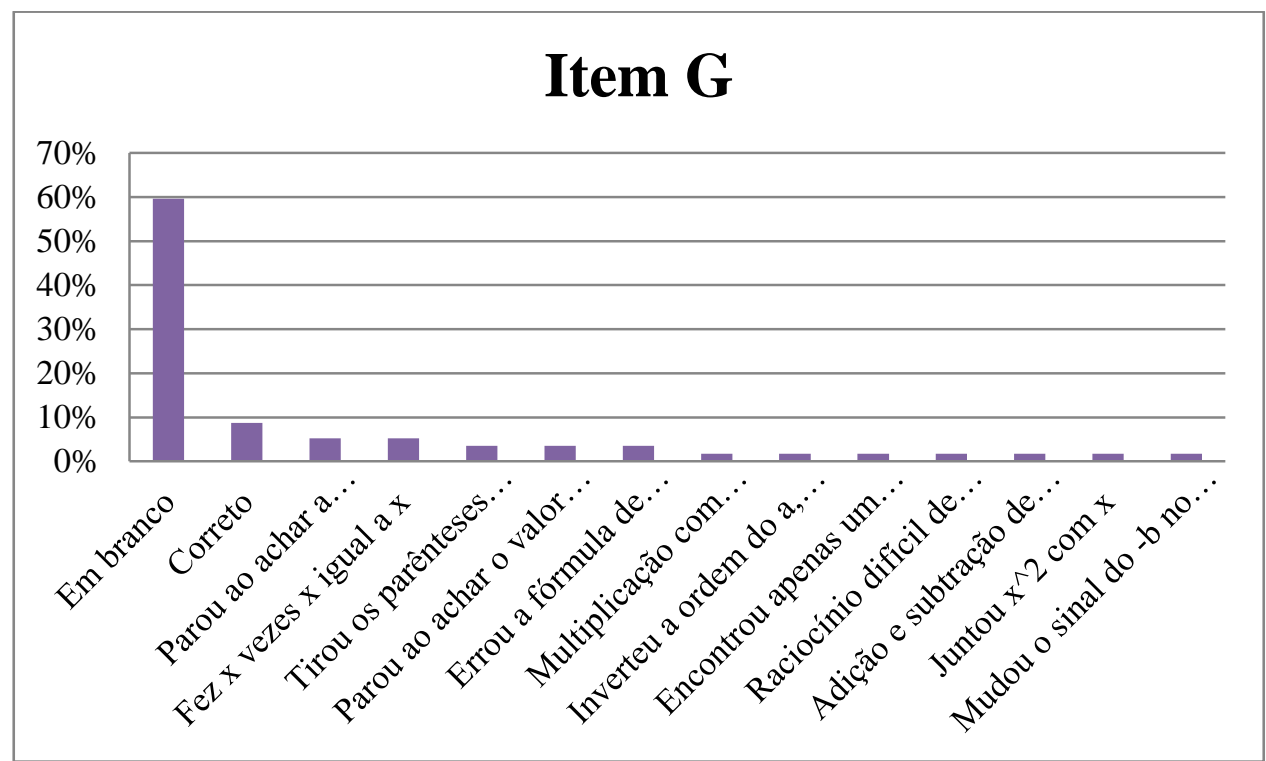

Gráfico 19 - Resolução do Item G

Logo de início, pode-se notar uma rigidez de raciocínio, pois os alunos que resolveram a equação aplicaram a distributiva, ao invés de observarem que se $a \cdot b=0$, então $a=0$ ou $b=0$. Além disso, optaram por aplicar a fórmula de Bháskara, já que era o procedimento mais confortável para a resolução. Vamos observar alguns casos específicos. 


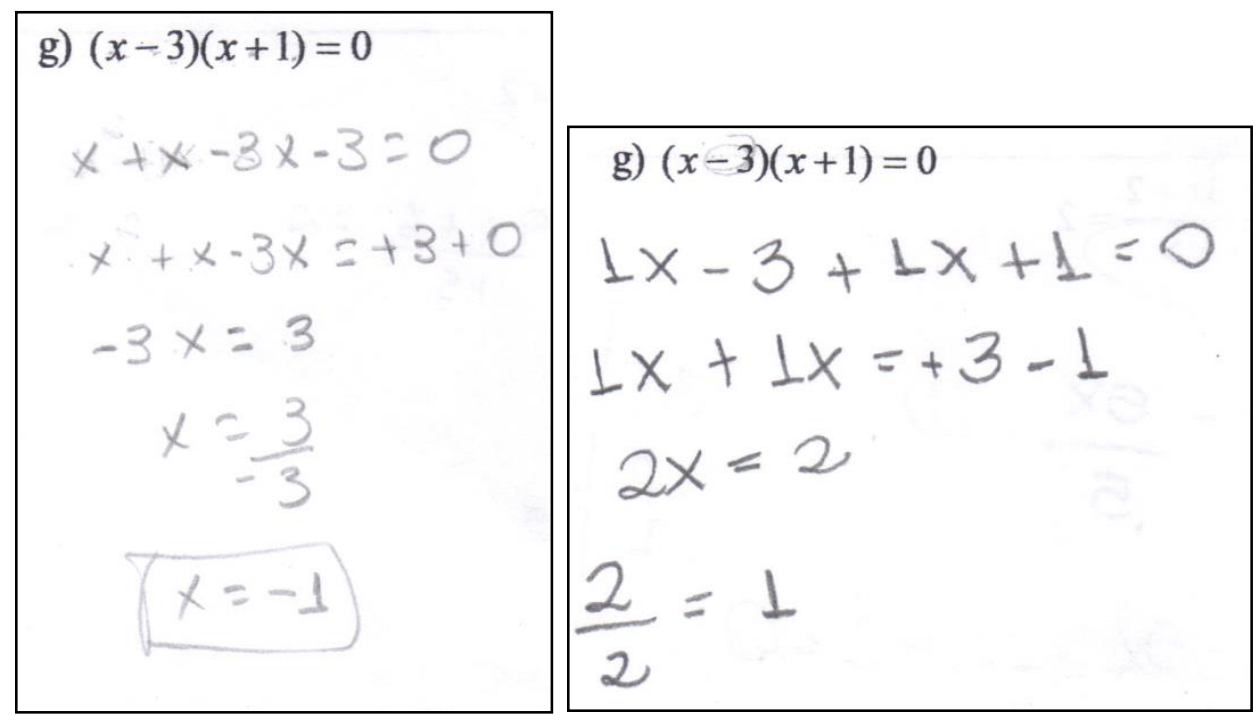

Figura 46 - Resolução de aluno

Figura 47 - Resolução de aluno

Nesses dois casos, os alunos chegaram a uma equação do primeiro grau. O da esquerda fez $x \cdot x=x$ na distributiva. $\mathrm{O}$ da direita apenas retirou os parênteses sem aplicar a distributiva. Em ambos os casos, acredito se tratar de um erro devido a uma aprendizagem prévia deficiente ou até uma dificuldade na linguagem.

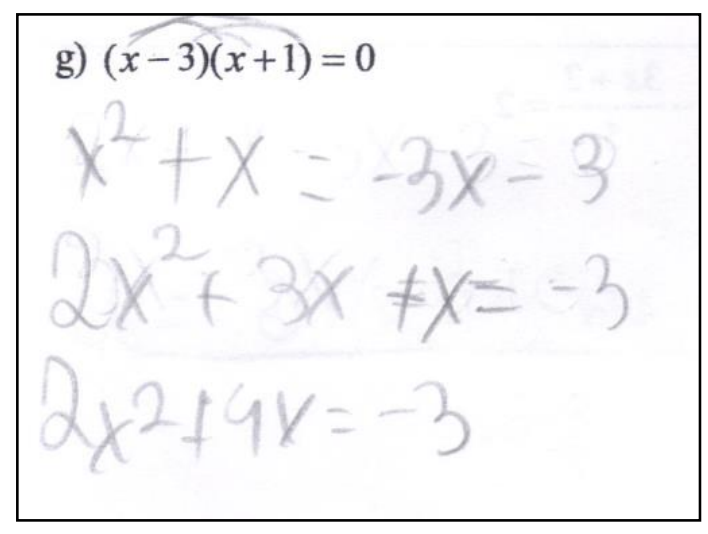

Figura 48 - Resolução de aluno

Já nesse caso, o aluno fez corretamente a distributiva, porém colocou parte do resultado do lado esquerdo da igualdade e parte do lado direito. Depois, passou letra para o primeiro membro da equação e número para o segundo, não sabendo finalizar o raciocínio. Aqui é possível que sejam erros devidos a uma dificuldade na linguagem ou a uma aprendizagem prévia deficiente. 


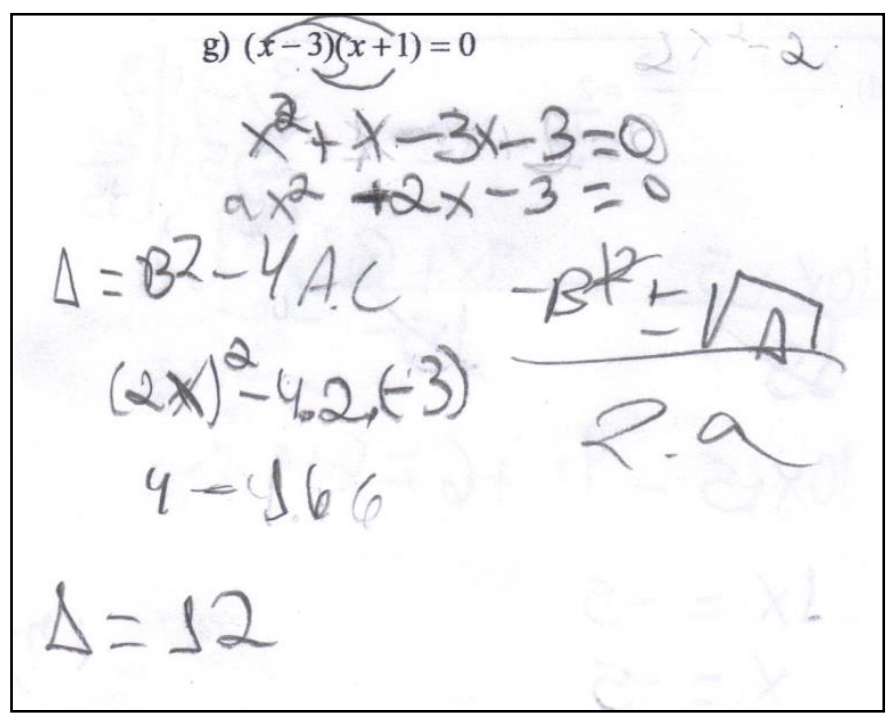

Figura 49 - Resolução de aluno

Aqui temos um aluno que utilizou $b=2 x$ e $a=2$ na fórmula de Bháskara e, em seguida, se equivocou na conta, fazendo $-4 \cdot 2 \cdot(-3)=-16$, em que se nota uma dificuldade em trabalhar com números inteiros, além de não ter finalizado o raciocínio. Os erros talvez sejam oriundos de uma aprendizagem prévia deficiente, mas também podem ser devidos ao cálculo incorreto.

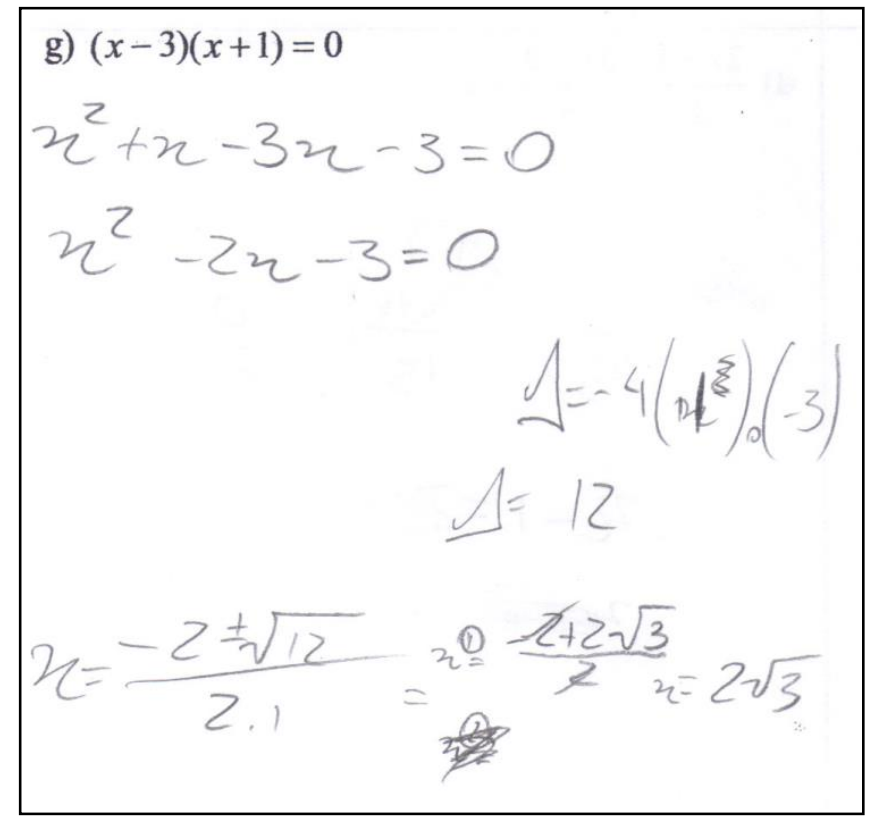

Figura 50 - Resolução de aluno

Nesse caso, o aluno errou a fórmula do discriminante, talvez por descuido, talvez por não a conhecer bem, tratando-se, então, de um erro devido a uma aprendizagem prévia deficiente. 
Vale observar que o aluno trabalhou bem com a $\sqrt{12}$, fatorando e transformando-a em $2 \sqrt{3}$ corretamente.

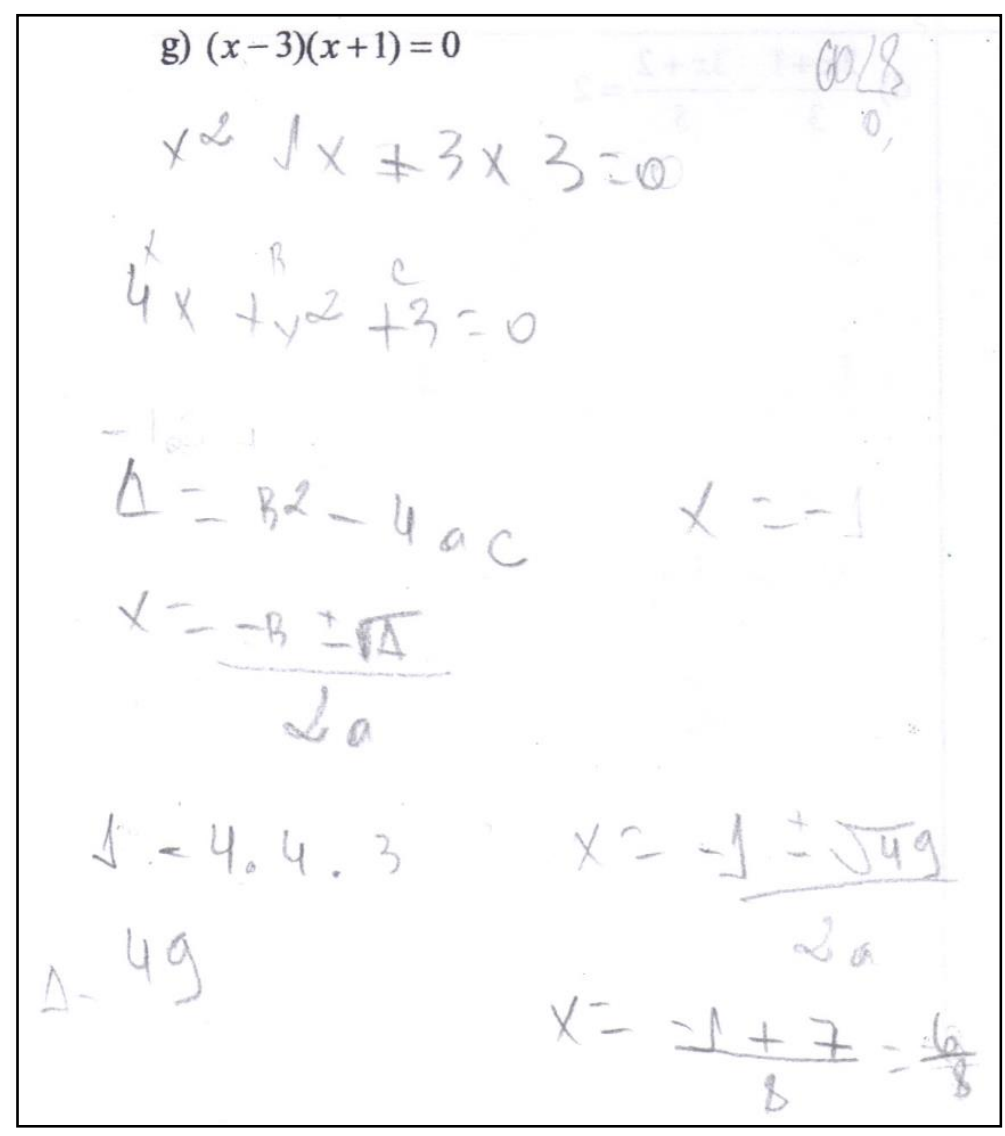

Figura 51 - Resolução de aluno

No último exemplo, o aluno se atrapalha com os sinais na distributiva e, em seguida, não organiza a equação, chegando a valores de $a$ e $b$ equivocados para o Bháskara. Talvez todos os exemplos de equações do $2^{\circ}$ grau que ele conheça sejam já com os termos organizados. Acredito, então, se tratar de erros devidos ao cálculo incorreto e à aprendizagem prévia deficiente. 
Item H: Resolver $(x+1)(x+2)=6$.

\begin{tabular}{lc}
\hline \multicolumn{2}{c}{ Item H } \\
\hline Em branco & $71,9 \%$ \\
Correto & $7,0 \%$ \\
\hline Fez x vezes x igual a x & $5,3 \%$ \\
Tirou os parênteses sem aplicar a distributiva & $3,5 \%$ \\
\hline Não passou o 6 pro outro lado & $3,5 \%$ \\
\hline Parou ao achar a equação de 2o grau & $1,8 \%$ \\
Errou a fórmula de Bháskara & $1,8 \%$ \\
Adição e subtração de números inteiros & $1,8 \%$ \\
Mudou o sinal do -b no Bháskara em cada um dos casos & $1,8 \%$ \\
\hline Raciocínio difícil de compreender & $1,8 \%$ \\
\hline
\end{tabular}

Tabela 14 - Resolução do Item H

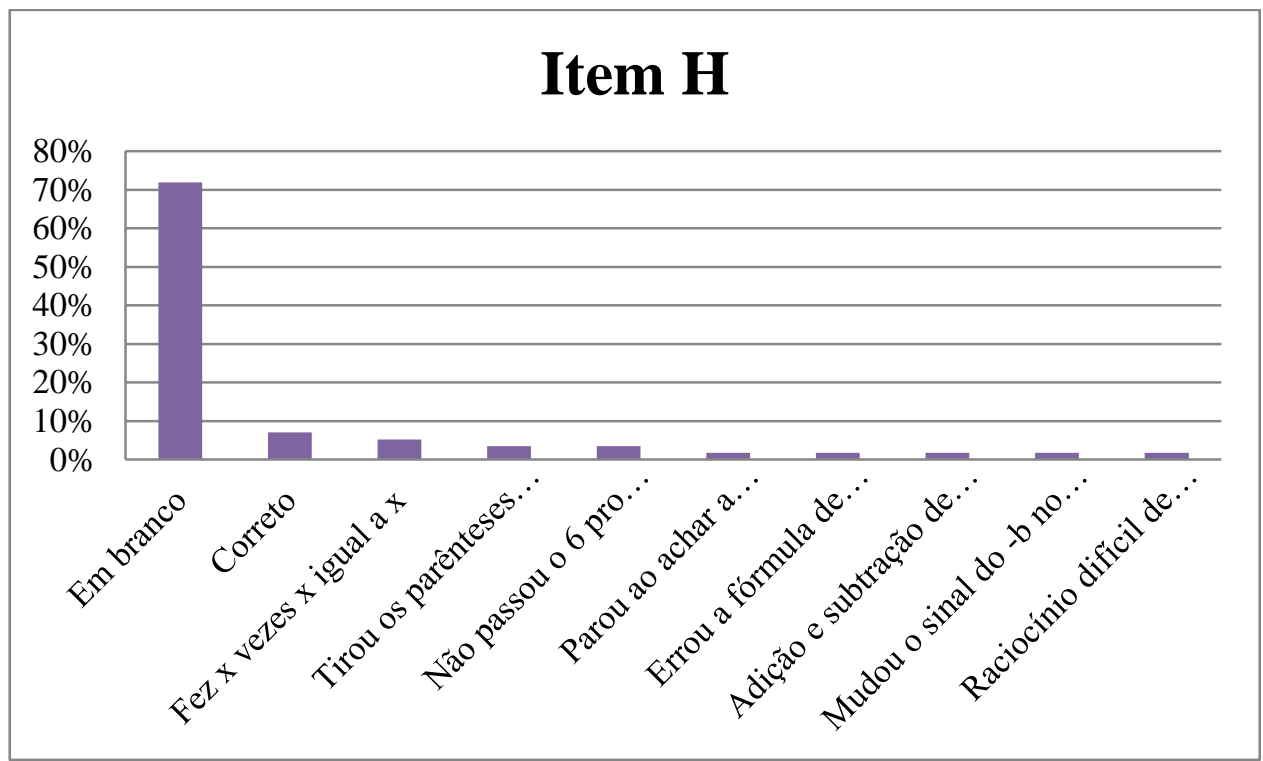

Gráfico 20 - Resolução do Item H

Esse foi o item com maior percentual de questões em branco e, dentre as resolvidas, os erros são muito similares aos do item anterior. Esperava-se que o aluno que resolveu o item anterior separando em dois casos, o fizesse aqui também, porém, como não houve tal aluno, não foi possível analisar dessa forma.

Além dos erros já mencionados, alguns alunos fizeram o Bháskara na equação sem passar o 6 para o lado esquerdo e igualar a zero. Acredito que isso esteja relacionado ao conceito de equação do $2^{\circ}$ grau e às regras para a aplicação da fórmula. Sendo assim trata-se de um erro 
devido a uma aprendizagem prévia deficiente. Observem-se a seguir alguns exemplos deste item.

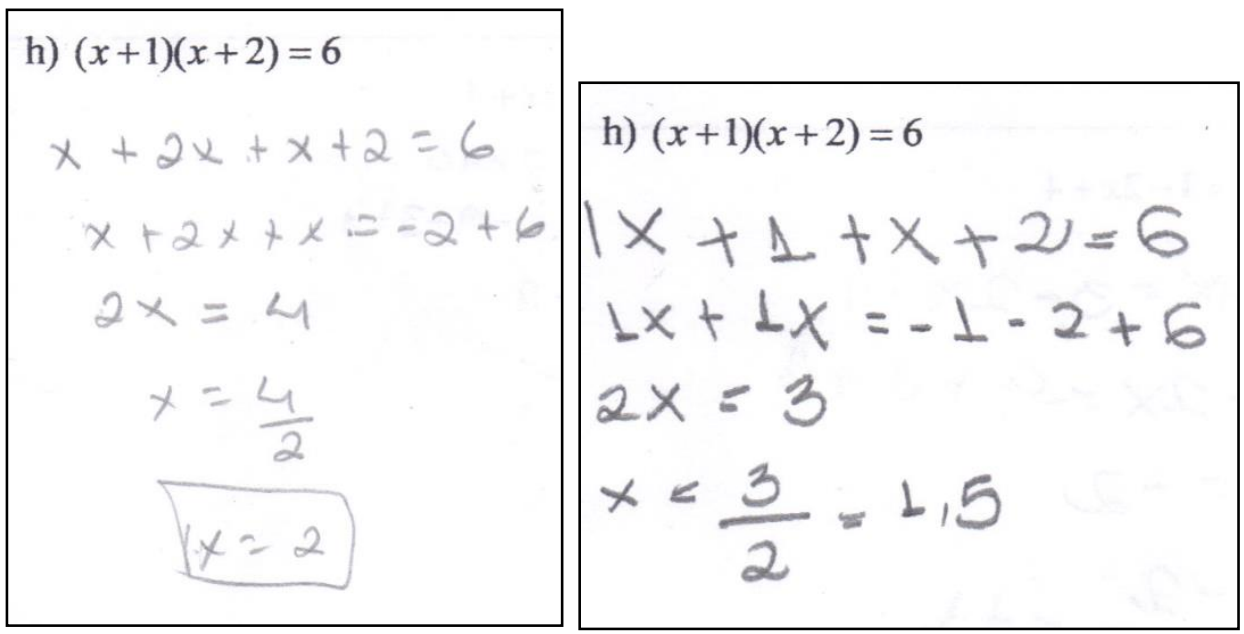

Figura 52 - Resolução de aluno

Figura 53 - Resolução de aluno

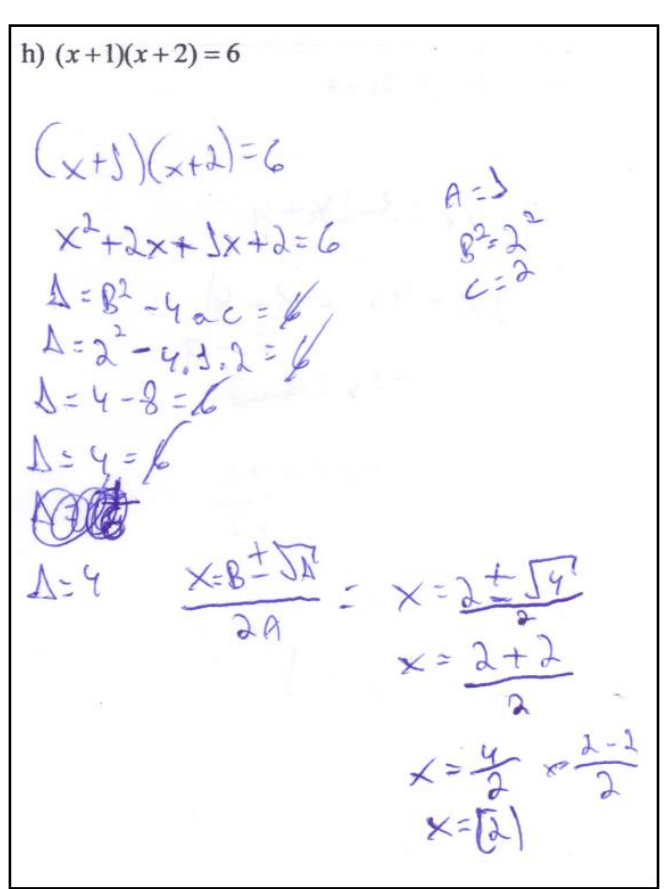

Figura 54 - Resolução de aluno

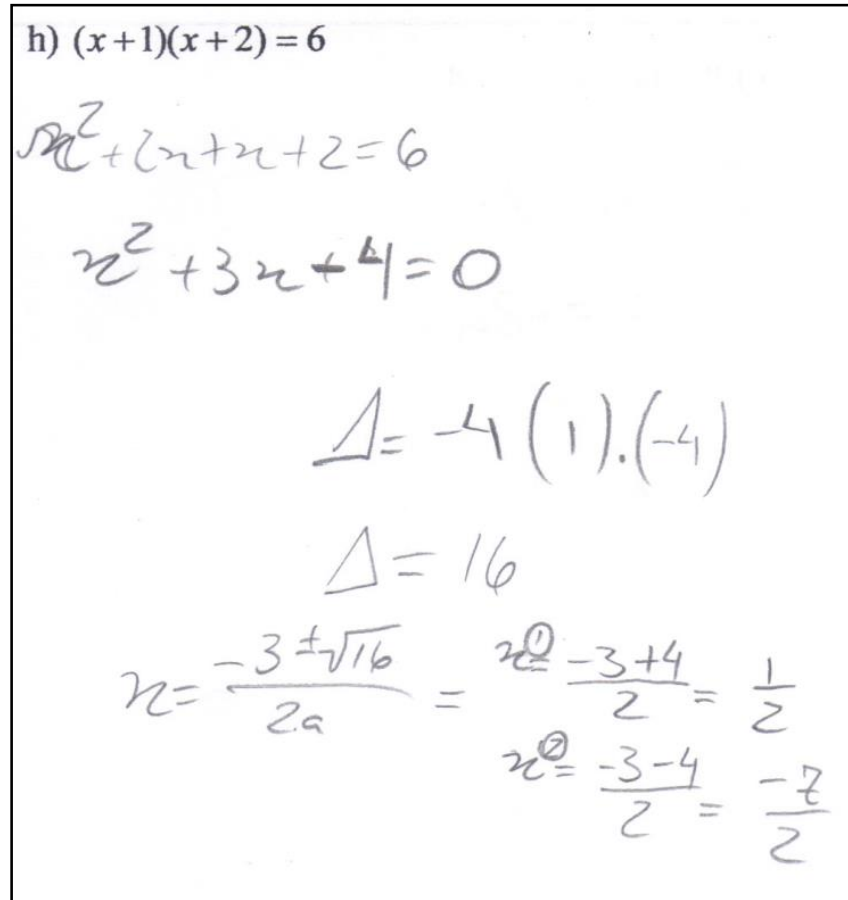

Figura 55 - Resolução de aluno 


\section{Análise por erros mais comuns}

Fazendo uma análise das respostas dos alunos, foi possível perceber alguns erros recorrentes na maioria dos exercícios.

Como observado na análise feita por questão, muitos alunos apresentaram dificuldades na resolução de equações quando se trata de manipular a equação a fim de isolar o $x$, pois o processo de "passar para o outro lado" é algo confuso para muitos alunos. Acredito que muitos deles decoram procedimentos sem entendê-los, como já foi dito.

As operações com números racionais também foi um tema que apresentou muita dificuldade. Muitas vezes os alunos não calculam o MMC para igualar os denominadores, outras vezes sabem que devem calcular o MMC e não alteram o numerador, esquecendo-se do conceito de frações equivalentes. Essa ideia pode ser vista também no trabalho de Vinner, Hershkowitz e Bruckheimer (1981), no qual foram trabalhadas operações básicas com frações e os alunos apresentaram os mesmo erros aqui citados.

Também é importante destacar as operações com termos não semelhantes, ou seja, quando o aluno faz uma soma ou uma subtração com um termo em $x$ e outro sem $x$, ou equivalente, com um termo em $x^{2}$ e outro em $x$. Ainda dentro dessa categoria, coloquei os erros do tipo $x \cdot x=x$, em que o aluno não sabe manipular expressões algébricas.

E, ainda, as operações com números inteiros, quando o aluno erra o sinal ou até mesmo o valor numérico do resultado. Esse é mais um erro que eu acredito que seja oriundo de conceitos não absorvidos adequadamente e regras memorizadas mal aplicadas.

Na tabela a seguir, é possível observar a quantidade de alunos que apresentou cada um dos erros citados, em pelo menos um dos 8 itens do questionário. Lembrando que se tratava de 57 alunos, os números mostram um quadro preocupante.

\begin{tabular}{lcc}
\hline Erros relacionados a... & Número de alunos & Porcentagem \\
\hline Mudança de lado dos termos da equação & 50 & $87,7 \%$ \\
Operações com racionais & 50 & $87,7 \%$ \\
Operações com termos não semelhantes & 15 & $26,3 \%$ \\
Operações com inteiros & 14 & $24,6 \%$ \\
\hline
\end{tabular}

Tabela 15 - Erros mais cometidos nas resoluções do questionário 2 
Considerando o total de erros cometidos como 100\%, segue um gráfico mostrando a dispersão dos erros citados. Mais uma vez é possível notar uma dificuldade em trabalhar com equação e com frações.

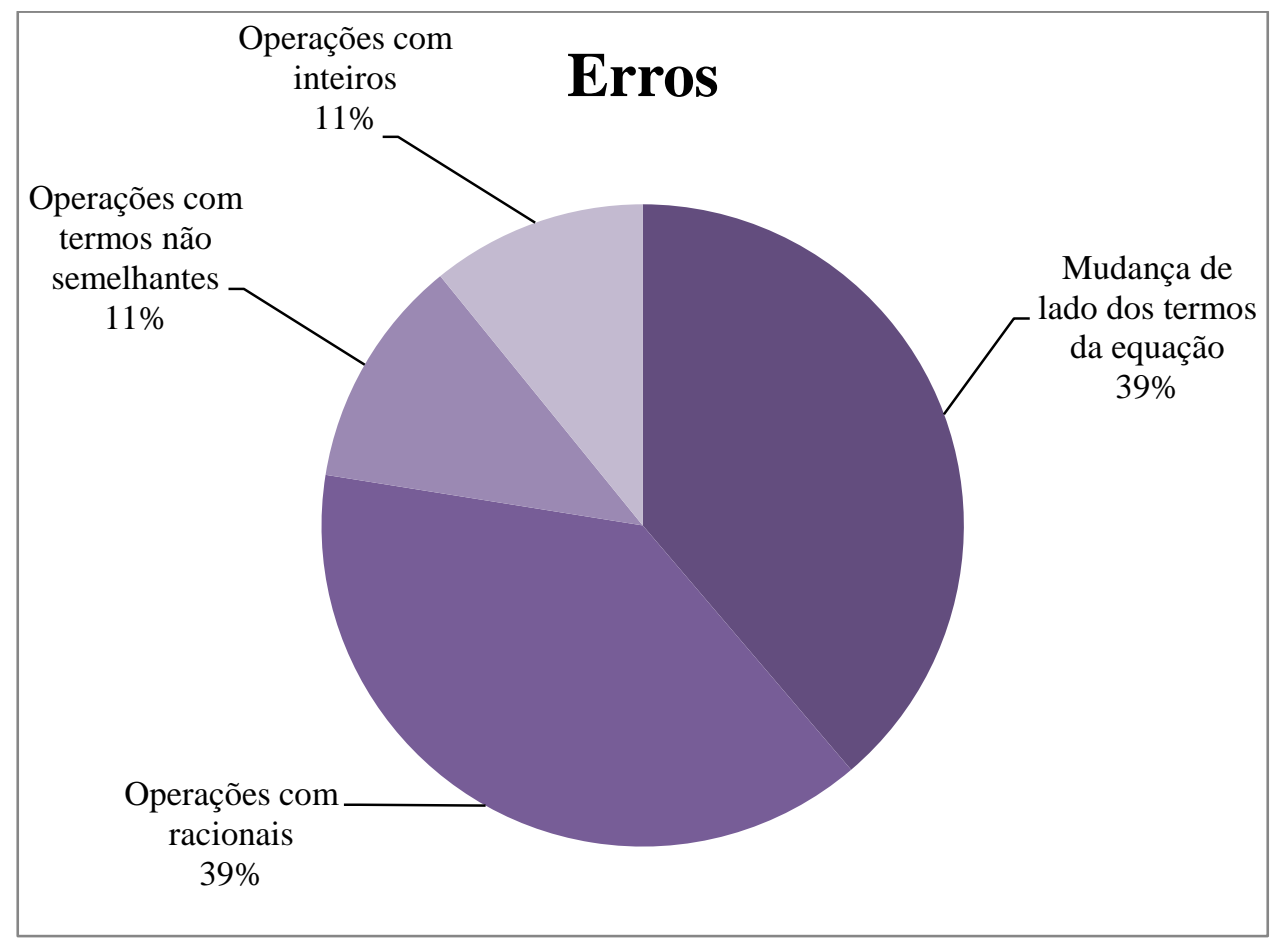

Gráfico 21 - Erros mais cometidos nas resoluções do questionário 2 


\subsection{CONCLUSÕES PARCIAIS}

Observando as resoluções dos alunos, além das tabelas e dos gráficos anteriores, pode-se perceber que os erros são compatíveis com os encontrados no primeiro questionário:

- Operações com números inteiros;

- Aplicação de regras equivocadas ou generalizadas erradamente;

- Manipulação de equações;

- Operações com números racionais.

Além desses erros que foram reforçados, é possível constatar também alguns erros relacionados a algoritmos mal utilizados para o cálculo do MMC e aplicação da distributiva, os quais muitos alunos não sabem utilizar para sua correta finalidade. Sendo assim, acabam se tornando processos puramente mecânicos que geram erros.

Vale ressaltar aqui também que, durante a aplicação do questionário, como já mencionado, a professora de Matemática estava na sala. Quando ela reparou que os alunos estavam com dificuldades básicas nos exercícios, ela fez um discurso em sala sobre o que é "resolver uma equação", como fazemos para "isolar o $x$ " e deu algumas dicas para alunos que requisitaram sua ajuda. A professora, então, teve uma atitude típica do Efeito Topázio, antecipando o resultado em que os alunos deveriam chegar sozinhos.

Após a análise dos resultados do segundo questionário, é possível reafirmar que os erros cometidos com maior frequência são relativos à generalização de regras, à aprendizagem prévia deficiente e à dificuldade na linguagem, conforme classificação mencionada na página 37. 


\section{ENTREVISTAS}

Para analisar melhor as resoluções dos alunos, foram selecionados alguns dos que responderam ao segundo questionário para uma entrevista individual sobre o que foi realizado. $\mathrm{Na}$ entrevista, eu pretendia entender os erros cometidos, visto que para Borasi (1996), explorar os erros juntamente com os estudantes, fazendo descobertas sobre os conteúdos em questão, pode ajudar a criar estratégias de ensino para retomar os conteúdos nos quais os alunos mostraram mais dificuldades.

Cury (1994) também defende essa ideia, pois, em sua tese de doutorado, entrevistou alguns professores, em 1994, que citaram erros relativos ao período do atual Ensino Fundamental, mostrando exemplos que envolviam aplicações de fórmulas e regras. Já em 2006, ela formula a hipótese de que os erros envolvendo operações básicas fossem oriundos de alunos que decoram regras impostas por seus professores sem entender seu real significado. E sugeriu que fossem feitas entrevistas com os alunos sobre suas formas de pensar.

Sendo assim, analisando os erros mais frequentes já mencionados, selecionei os alunos que mais tiveram esses erros em suas produções. Também houve um caso especial: um aluno me perguntou sobre a devolução do questionário corrigido, pois ele queria saber o que havia acertado ou errado. Como esse aluno foi o único que manifestou interesse em saber se suas respostas estavam corretas, eu o chamei para participar das entrevistas. Segundo esses parâmetros, foram selecionados 12 alunos ${ }^{10}$.

A realização das entrevistas ocorreu uma semana após a aplicação do segundo questionário, para tentar garantir que os alunos se lembrariam, com uma maior riqueza de detalhes, da resolução que fizeram. Os alunos foram retirados da sala de aula durante uma aula de Matemática e levados para uma sala reservada onde foram questionados sobre suas resoluções. A ideia era deixá-los explicar o que fizeram para que eu pudesse entender seu raciocínio. O tempo de duração de cada entrevista foi em torno de 10 minutos.

Como foi pedida a autorização dos alunos para gravar as entrevistas, muitos deles chegaram com receio de falar o que pensaram, mas com o decorrer da conversa, eles foram se sentindo mais à vontade.

\footnotetext{
${ }^{10}$ Transcrição das entrevistas em anexo.
} 
Como muitos deles apresentavam diversas dificuldades básicas, ou por conta da greve ou mesmo por um ensino defasado, conforme explicavam seu raciocínio sobre um determinado tema, eu finalizava com uma explicação rápida sobre o assunto. Senti necessidade de ajudá-los com aqueles conteúdos, já que, no $3^{\circ}$ ano do Ensino Médio, eles ainda apresentavam tamanha dificuldade. Muitas vezes foi necessário induzir ou explicar algumas coisas, para poder dar continuidade à entrevista. A ordem dos exercícios e o roteiro pensado para a entrevista, na maioria das vezes, deixaram de ser importantes. 


\subsection{ANÁLISE}

A análise será feita com base nas ocorrências mais comuns que se manifestaram durante as entrevistas. É importante pontuar que o nome dos alunos foi mantido em sigilo e estes serão tratados aqui como "Aluno A" e o entrevistador será tratado como "Entrevistador E". A transcrição completa das entrevistas encontra-se em anexo.

\section{Mudança de lado dos termos da equação}

Ao ensinar equações, no Ensino Fundamental II, o professor faz uso de alguns materiais, como cita D’Amore (2007), criados para auxiliar na transposição didática. Alguns desses materiais já foram citados anteriormente, porém era apenas uma suposição que os alunos os utilizassem de maneira inapropriada. Durante a realização das entrevistas, foi possível constatar a constante utilização da ideia de que, quando algo muda de lado, deve-se "trocar seu sinal", muitas vezes de maneira errada ou sem entender o seu real motivo. Seguem alguns exemplos em que a resposta dos alunos está prontamente relacionada a essa regra.

\section{ENTREVISTA 02}

E: Então, mas o que acontece quando você vai passar um número pro outro lado?

A: Troca o sinal.

ENTREVISTA 03

E: Por quê? Quando muda de lado a gente faz o quê?

A: Quando a gente muda de lado a gente inverte o sinal.

\section{ENTREVISTA 06}

E: Por que que virou $-x$ ?

A: Porque esse $x$ foi pro outro lado também.

E: E aí quando vai pro outro lado acontece o quê?

A: O sinal muda.

\section{ENTREVISTA 08}

A: É que eu sei que tem que passar o $x$ pra um lado e número pro outro.

E: E quando muda de lado não acontece nada?

A: Aí muda o sinal. 
Muitos dos alunos, mesmo quando questionados sobre esse processo, insistiram na ideia de que o sinal deve mesmo trocar, inclusive nos casos em que o número deveria passar para o outro lado dividindo, sem alterações no sinal. Trata-se, portanto, da generalização de uma regra feita de forma errada. Observe:

\section{ENTREVISTA 02}

E: Troca o sinal sempre?

A: Ele passa multiplicando aí tu passa pro outro lado dividindo.

E: Passa dividindo. Então na realidade o que ele troca é a operação.

A: A operação e o sinal.

$[\ldots]$

E: O que você acha? Que tem que trocar o sinal sempre?

A: Creio que sim. Quando passa de um lado pro o outro.

E: Mas aí inverte o sinal e a operação?

A: É.

\section{ENTREVISTA 06}

E: Mas dava pra continuar aqui. Como que você continuaria? Se tivesse certa essa parte.

A: Eu voltaria o 2 pro outro lado.

E: O 2 pro outro lado? E como que ele ficaria? Ficaria...

A: Dividido.

E: Dividido? E aí não muda o sinal?

A: Mudaria também.

Inclusive, quando confrontados com essa ideia de mudar o sinal e a operação, muitos dos alunos que haviam resolvido corretamente, acabaram se convencendo de que sua resolução estava errada e que o sinal também deveria ter sido alterado, além de efetuar a operação inversa com o número em questão, como vemos nos exemplos a seguir:

\section{ENTREVISTA 04}

A: Aí depois eu fiz -4 dividido por 2.

E: Aqui quando você passou esse 2 ele tava multiplicando, passou pro lado de lá dividindo e trocou o sinal?

A: Trocou.

E: Então toda vez que muda de lado troca o sinal?

A: É. 
E: Mesmo quando tá multiplicando e dividindo?

A: Isso.

E: E aqui você não fez isso, olha, esse aqui, como é bem parecido e aqui era

$-4 x$ e você passou o -4 dividindo sem trocar o sinal dele. Qual dos dois você acha que tá certo?

A: Esse. (se referindo ao item em que trocou o sinal e a operação)

E: Esse aqui?

A: É.

E: Então toda vez que troca o sinal... toda vez que troca de lado, muda o sinal?

A: Isso.

\section{ENTREVISTA 05}

E: Mas e esse 2 aqui? Olha, era $2 x=-4$. Você passou o 2 pro outro lado e ele não trocou de sinal. Por quê?

A: Não, na verdade eu que tinha colocado aqui, daí eu tinha multiplicado por

-1 né, daí vai ficar os dois positivos. Daí depois eu... é eu esqueci de colocar o menos aqui.

\section{ENTREVISTA 06}

A:[...], o 2 vai passar pra cá e ia dividir.

E: Dividir por 2 ou por -2 ?

A: Por -2 .

E: Mas quando passa pro outro lado não troca o sinal?

A: Troca o sinal, daí fica positivo.

E: Fica positivo? Então divide só por 2?

A: Pronto.

Isso mostra que há uma aprendizagem prévia deficiente por parte de muitos alunos e significativamente frágil, pois eles não têm embasamento para defender os seus pontos de vista. Os alunos acabam decorando métodos ensinados pelo professor, porém não entendem de onde vêm os conceitos do procedimento utilizado. É possível ver isso também nos exemplos a seguir.

ENTREVISTA 09

E: E aí você passou o 4 dividindo. Por que é que ele passa dividindo?

A: Não sei, porque é sempre dividindo. Não é?

E: Sempre? Aqui esse -3 não passou pra lá dividindo.

A: Não, eu só divido quando chega aqui. 
E: Só no último passo então?

A: É.

\section{ENTREVISTA 11}

A: Não, mas é porque a regra é que quando tá multiplicando passa pra lá dividindo, e não passa pra lá dividindo negativo, entendeu?

Até mesmo o conceito de equação e igualdade foi questionado. O que significa "passar para o outro lado" e por que podemos usar essa noção com equações? As respostas a essas perguntas vêm da ideia primitiva de equação e pode ser vista em dúvida no seguinte exemplo:

\section{ENTREVISTA 11}

E: Você passou o $5 x$, passou pra cá, ele já tava aqui, aí você passou pra lá. Eles deveriam estar do lado direito.

A: Não, mas não tem problema, tem?

E: Lógico que tem. Se você passou ele pra cá, quem devia estar negativo era o $5 x$ e positivo o $x$. Aí ficaria $-5 x+x$, ia dar $-4 x$.

Em poucos casos foi possível ver a resolução correta acompanhada do raciocínio correto. Nesses casos, os alunos enfatizaram que o que troca, ao mudar um termo de lado, é a operação e não o sinal. Alguns deles disseram por conta própria e outros falaram após serem corrigidos pelo entrevistador.

\section{ENTREVISTA 01}

A: Ele inverte a... Quando ele tá somando ele passa subtraindo, entendeu? Quando tá dividindo ele passa multiplicando.

E: E esse 2 aqui? Por que você passou ele pro outro lado?

A: Porque quando ele passa... Quando ele tá multiplicando... é multiplicando aqui, aqui ele passa dividindo, que é a operação inversa.

E: Entendi. Então quando muda de sinal, quando ele passa pro... quando ele muda de lado acontece o quê?

A: A operação fica inversa.

\section{ENTREVISTA 02}

A: Tô pensando aqui. Ele está dividindo, então posso passar pro outro lado multiplicando.

$[\ldots]$ 
A: Tá certo. Aí ficaria $4 x+4=x-2$, aí depois $4 x-x=-2-4$, então $3 x=-6, x$ igual a -6 dividido por 3 .

E: 3 positivo ou negativo?

A: Esse 3 é positivo.

E: Por quê?

A: Por causa que só muda a operação.

\section{Operações com números racionais}

A resposta dos alunos a operações com frações já é estudada há muito tempo por se tratar de um assunto em que eles apresentam bastante dificuldade. Em 1981, Vinner, Hershkowitz e Bruckheimer (1981) fizeram um estudo sobre a causa dos erros em adições de frações. Eles classificaram esses erros em três grandes categorias:

1) Quando não há indício do algoritmo do denominador comum (dentro dessa categoria eles colocam casos como aqueles em que os alunos somam o numerador e multiplicam o denominador ou vice e versa, quando ambos são multiplicados ou somados, ou até mesmo quando o numerador é somado e o denominador, ignorado);

2) Quando há indício do algoritmo do denominador comum, mas o conceito de frações equivalentes se perdeu (nesta categoria enquadram-se os casos nos quais os alunos utilizam uma linha comum para o denominador das duas frações a serem somadas ou quando o denominador comum é encontrado após somarem-se todos os denominadores anteriores e deixados os numeradores intactos);

3) Quando há indícios do algoritmo do denominador comum e do conceito de frações equivalentes (aqui se encaixam os casos nos quais o aluno obtém o denominador comum somando ou multiplicando os demais denominadores e o novo numerador é obtido somando os valores do antigo, ou quando o denominador comum é feito corretamente, mas o novo numerador é obtido por algum processo equivocado).

Sendo assim, pode-se ver que eles já constataram uma série de erros que ainda encontramos nas resoluções dos alunos. Como os conceitos mais trabalhados nos questionários foram o de adição e subtração de frações, explorando o algoritmo de frações equivalentes que 
envolvem o cálculo do Mínimo Múltiplo Comum (MMC), foi possível perceber que muitos alunos não entendem o conceito envolvido no cálculo do $\mathrm{MMC}$, pois realizam o procedimento apenas porque alguém disse que era necessário fazer, sendo que, muitas vezes, nem sabem a sua real utilidade. Nota-se, então, que os erros cometidos se enquadram nas categorias de Vinner, Hershkowitz e Bruckheimer. Nas falas reproduzidas a seguir fica muito claro que, para o aluno, o cálculo do MMC é apenas uma formalidade que deve ser cumprida.

\section{ENTREVISTA 01}

E: E o que você lembrou? Só que tinha que tirar o MMC?

A: Sim, e aí como eles são números ímpares, dava pra multiplicá-los, e eu esqueci disso. E dava 15, aí depois era só você fazer... é, multiplicaria em cruz.

E: Mas é porque eles... Porque são números ímpares? E se fosse 3 e 15 ?

Também multiplicaria? São dois números ímpares.

A: É, não sei.

E: Qual seria o MMC de 3 e 15 ?

A: É, não sei. Tem que ver na hora, né?

E: (Risadas)

A: Você me confundiu (risadas).

\section{ENTREVISTA 03}

A: Eu tirei o MMC por causa que aqui tinha o... qual é o nome?

E: Denominador.

A: O denominador 3, o denominador 5 e o denominador 1, aí eu tive que tirar o MMC pra saber um denominador para todos e foi o 15.

E: Por que é que eles têm que ter o mesmo denominador?

A: Por causa que não vai dar pra fazer a conta se tiver assim. Ou dá e eu não sei.

\section{ENTREVISTA 05}

E: Mas você lembra o que você fez, mais ou menos? Por que ficou todo mundo sobre 15 ?

A: Porque... aí você multiplica o de cima pelo de baixo, né? Aí você coloca aqui, aí depois a gente cortou o 15. Daí ficou a...

E: Multiplica o de cima pelo de baixo? Como assim?

A: É. Tipo, a gente fez assim, daí... nem lembro direito como a gente fez.

E: Como você chegou nesse 5 e esse 3 do parênteses?

A: Calma, fez 3 vezes 5, daí ficou 15 . 
E: "Aham".

A: Daí ficou 15, 15 aqui, né, pra deixar igual e aí cortou. Aí ficou a conta aqui e a gente isolou o $x$ do mesmo jeito.

\section{ENTREVISTA 09}

A: Essa daqui eu não lembrava como fazia, só lembrava que... eu falei assim "Não, eu acho que tem que fazer o MMC, porque sempre quando tem número embaixo e em cima nas contas tem que fazer o MMC".

\section{ENTREVISTA 11}

A: Aí esse aqui eu fiz o MMC.

E: Por que é que tem que fazer o MMC?

A: Porque tem dois números no...

E: Denominador.

A: É.

E: Dois números diferentes. E se fosse 3 e 3, teria que fazer o MMC?

A: Sim.

E: Também?

A: É, eu faço sempre, não interessa o número.

E: Mas por quê? Você faz porque disseram que tem que fazer?

A: Não, eu faço porque eu aprendi assim, tipo, quando não tem nada é 1, é meio que visível assim, eu bato o olho e vejo que tem que fazer o MMC.

\section{ENTREVISTA 12}

A: Eu tirei o MMC de 3 e 5.

E: Por quê?

A: Porque quando tem número em fração tem que fazer o MMC.

E: Sempre?

A: Sim.

$[\ldots]$

E: Entendi. E nesse daqui se eu colocar o $x+1$ ele estaria sobre quanto, se não tá nada escrito? Quando não tem nada escrito é o que?

A: Zero?

E: Sobre 1. Então fica $x+1$ sobre 1, aí daria pra tirar o MMC também. 
de menos na frente da fração. Quando encontraram um denominador comum, o sinal de menos passou a ser somente do primeiro termo da fração e não de ambos como deveria ser. A seguir um exemplo desse erro.

\section{ENTREVISTA 02}

E: Por que você tinha circulado esse sinal de menos aqui?

A: Coloquei ele entre parênteses pra mim porque acho mais fácil de diferenciar na hora de continuar a equação.

E: Então, mas aqui você circulou o sinal de menos.

A: Não, isso é porque eu estava explicando pra um colega meu.

E: Entendi. Mas esse sinal de menos aqui, é um sinal da fração toda, não é?

A: Isso porque ele tá aqui. Como ele ficou junto com o 9 positivo, coloquei o 9 entre parênteses pra poder diferenciar.

E: Mas por que só o 9 e o 6 não?

A: É porque é o 9 que tá em contato, vamos dizer assim, com o sinal positivo.

E: Mas então, esse menos não é da fração toda?

A: É.

E: E o $3 x$ e o 2 tavam na fração?

A: Tá certo. Então o 6 ficaria negativo também.

\section{Operações com termos da expressão polinomial}

Muitos alunos fizeram conta com termos não semelhantes, do tipo: juntar termo com $x$, com termo sem $x$ ou termo com $x$ e outro com $x^{2}$. Logo quando confrontados com essa situação, eles já se corrigiram, mas não foi questionado o porquê desse erro. Seguem alguns exemplos.

\section{ENTREVISTA 08}

E: Que é o igual que tá aqui. E aí $4 x-2$, eu posso fazer essa conta?

A: Pode.

E: Pode? Um tem $x$ e o outro não tem.

A: Verdade, não pode.

\section{ENTREVISTA 06}

E: Do enunciado pra sua primeira linha, o que você fez? Por que é que deu $-2 x$ 
A: Porque eu acho que eu somei aqui.

E: Pode somar?

A: Não.

E: -2 ? Um tem $x$ e o outro não tem, né?

A: É.

E: Então não pode. Aqui o que você fez? Transformou essa subtração numa multiplicação, virou 2 vezes $x$ e era pra ser $x-2$.

\section{ENTREVISTA 12}

A: Aqui eu resolvi.

E: Resolver aqui significa fazer o quê?

A: $3 x+1$.

E: Dá pra juntar $2 x$ com 1 ?

A: Dá.

E: Por que é que você não juntou aqui, $5 x+5$ não deu $10 x$.

A: É verdade.

E: Não dá pra juntar quando tem $x$ e quando tem número.

\section{ENTREVISTA 01}

A: Eu fiz $2 x^{2}$ mais...

E: Mas o que você juntou para dar $2 x^{2}$ ?

A: $2 x^{2} ?$

E: Sim.

A: No caso eu fiz $x$ mais $x$ e coloquei $2 x^{2}$. Mas teria que ser $x^{2}$ mais $x^{2}$. (Risadas).

Alguns deles trabalharam com termos semelhantes, porém de maneira errada. Alguns por conceitos de contas outros por não adaptar essas contas aritméticas às contas com variáveis.

\section{ENTREVISTA 09}

E: Entendi. E aí $x-x$, você tem 1 e tá devendo 1 .

A: Fica só $x$.

E: Fica só $x$ ? Você não acabou de me dizer aqui que você tem 1 e tá devendo 1

é 0 ?

A: Mas é número. 
E: E aqui você tem $1 x$ e tá devendo $1 x$.

A: Não sei o que eu fiz.

E: Aí ficou só $x$ ?

A: É.

\section{ENTREVISTA 04}

E: E $x$ vezes $x$ dá quanto?

A: Dá... $x$.

E: Dá $x$ ?

\section{A: É porque 1 vezes 1 dá 1.}

Neste último exemplo, a frase destacada pode ser interpretada como um caso particular sobre a interpretação correta da operação $x \cdot x$, em que o aluno assume que, como a sua solução vale para $x=1$, então também vale para todo $x$. Porém, também pode ser considerada como uma errada generalização de regras. Pois, assim como fazemos as operações só com a parte numérica, quando se trata de adição de subtração de monômios semelhantes (por exemplo: $3 x+2 x=5 x$ ), seria possível que isso valesse para a multiplicação também (por exemplo: $3 x \cdot 2 x=6 x$ ). Sendo assim, o raciocínio $1 x \cdot 1 x=1 x$ seguiria essa linha.

\section{Operações com números inteiros}

Aqui, mais uma vez pode-se notar que os materiais, citados por D'Amore (2007) e ensinados pelos professores para auxiliar na transposição didática, muitas vezes são utilizados pelos alunos de maneira inapropriada. Durante a realização das entrevistas, foi possível notar a constante utilização da ideia da "regra de sinais" ensinada pelos professores do $6^{\circ}$ ano para simplificar as operações com números inteiros. Porém, muitas vezes, esta regra que vale somente para multiplicação e divisão é generalizada erroneamente para adição e subtração. Seguem alguns exemplos em que a resposta dos alunos foi prontamente relacionada a essa regra.

\section{ENTREVISTA 03}

A: Aí ficou $-4 x=8$. Aí aqui...

E: Quando você for passar esse 4 pro lado de lá, ele tava multiplicando e você passou ele dividindo. 
A: Passei.
E: Agora que ele é $-4 x$, o que é que isso mudaria?
A: Isso mudaria porque aqui ficaria mais com menos e ficaria -2 .

ENTREVISTA 04

A: Aí deu 2x. E fiz... porque mais com mais dá... menos com menos dá mais. Eu

fiz $3+1$ que deu -4 .

E: Mas se dá mais, por que deu -4 ?

A: É porque se eu tô devendo 3 e tô devendo 1 vai ficar... tô devendo -4 .

\section{ENTREVISTA 11}

A: Aí é a distributiva, aí $x$ vezes $x$ é $x^{2}, x$ vezes 1 é $x$ e mais com mais, dá mais. Certo?

E: Certo.

A: Aí -3 vezes $x$ dá $-3 x$. Aí -3 vezes 1 e menos com mais é menos, 3 vezes 1 é 3 , daí dá -3 igual a 0 .

E: Isso.

Observe-se que, no primeiro exemplo, o aluno não tem domínio sobre a regra, pois acaba chegando a um resultado equivocado. Por outro lado, ele apresenta domínio sobre o conceito, pois entende a ideia de devedor e números negativos.

\section{Efeito Topázio}

Muitas vezes o professor antecipa o resultado que o aluno deveria chegar sozinho, isso é o que caracteriza o Efeito Topázio, segundo Pais (2001). Durante as entrevistas eu fui protagonista desse efeito e, algumas vezes, foi possível ver os alunos reconhecendo tal interferência docente. Quando o entrevistador perguntou muitas vezes se os alunos tinham entendido a sua explicação, acabou induzindo a uma resposta afirmativa, sendo que, em alguns casos, o conceito envolvido não foi realmente absorvido. Observem-se alguns casos.

\section{ENTREVISTA 01}

E: Isso. Certo?

A: Não é difícil. 
E: Não é difícil? Já deu pra lembrar?

A: Já. Daí nesse aqui é a mesma coisa. Ficaria $2 x+2=x+4$.

E: Esse 4 aqui tá sobre quanto?

A: Tá sobre... nada, tá sozinho.

E: Tá sobre 1, né? Então pra você transformar ele em alguma coisa sobre 2, ele tem que multiplicar por 2 porque a fração... se você escrever 4 sobre 2 não representa 4 , você teria que escrever 8 sobre 2 pra poder representar o 4 .

A: 8.

E: Certo? Aí corta o 2 de baixo que nem a gente fez no anterior.

\section{ENTREVISTA 02}

E: Entendeu? Então quando a gente troca um número de lado, na realidade o que a gente troca, o que a gente inverte é a operação, tá? Aqui você fez a mesma coisa, você chegou no $-2 x=-2$ e aqui você dividiu por -2 e aí depois aqui você dividiu por 2 positivo. Você fez uma coisa de um lado e outra coisa do outro. Aí não mantém a igualdade. Tá?

A: Entendi.

\section{ENTREVISTA 08}

E: Que é o igual que tá aqui. E aí $4 x-2$, eu posso fazer essa conta?

A: Pode.

E: Pode? Um tem $x$ e o outro não tem.

A: Verdade, não pode.

A seguir alguns alunos que disseram entender, porém ao ser cobrado o mesmo conceito, foram novamente equivocados em suas respostas.

\section{ENTREVISTA 01}

E: E a parte de cima, por que você mudou os números?

A: A parte de cima é porque eu multipliquei em cruz, aí eu fiz 5 vezes $2 x$ e 5 vezes 1 , aí 3 vezes $3 x$ e 3 vezes o 2 .

$[\ldots]$

E: Qual é o denominador do $x+1$ ?

A: 1 .

E: 1, então você tira o MMC de 1 e 4. E qual seria o MMC de 1 e 4 ?

A: 1 e 4 dividido por 4 seria 2 , então ficaria 2 vezes 1 vai dá 2 . E aqui eu 
conseguiria multiplicar pelo $x$ ou teria que copiar ele primeiro?

E: Então, você tem que mudar a parte de cima, lembra? No outro você mudou a parte de cima também?

A: Mas e o igual? Deixa do jeito que tá?

E: Então, você tá colocando todo mundo sobre 2.

A: Certo.

\section{ENTREVISTA 04}

E: Então toda vez que troca o sinal... toda vez que troca de lado, muda o sinal?

A: Isso.

E: Eu vou te contar que é esse que tá certo. Toda vez que muda de lado a gente inverte a operação, não o sinal. Então por exemplo esse +3 que você trocou de lado, ele tava somando, quando você passou pro outro lado ele vai subtrair, por isso que parece que ele trocou de sinal, mas o inverso da operação da soma é a subtração. Nesse caso aqui, o 2 que tava multiplicando, ele vai passar pro outro lado dividindo e não troca o sinal, continua dividindo por 2.

A: Eu entendi.

$[\ldots]$

E: Isso. Você vai passar multiplicando o 4 ou o -4 ?

A: $\mathrm{O}$ menos porque mudou de lado.

E: Então, a gente acabou de falar sobre isso. Quando muda de lado troca o quê? A operação. Então tá multiplicando e vai passar... tá dividindo e vai passar multiplicando e vai continuar sendo 4. Então aqui era pra multiplicar por 4 só.

Muitas vezes os alunos dizem fazer algo somente porque o professor disse ser correto. Assim, vemos que seu espírito investigativo e curioso vem diminuindo pouco a pouco, pois aceitam o que lhe foi passado, sem querer saber o porquê existente por trás do aprendizado. Observemos alguns casos em que o aluno apenas reproduziu o que o professor lhe disse.

\section{ENTREVISTA 06}

A: Daí ficou igual a $x-1$. Daqui eu tava tentando não me perder, daí a professora falou pra mim que tava errado, daí eu deixei quieto.

\section{ENTREVISTA 08}

E: Por que você colocou todo mundo sobre 15 ?

A: Porque você tinha falado que precisa tirar o MMC, aí como eu fiz o MMC, deu 15 , mas eu tinha ficado em dúvida se tinha que tirar o 15 e colocar como 
fração ou não.

\section{ENTREVISTA 10}

A: A professora me explicou na hora. Ela falou pra mim o que tinha que fazer. Tinha que...

E: Não precisa ficar nervoso.

A: Eu lembro que você me explicou uma hora que precisava juntar todos... tipo, pegar assim na... pra dar um certo valor. Esse outro dar um certo valor, mas os outros tinham que dar um mesmo... tipo uma conexão. Aí eu fui tendo tipo um flashback.

\section{ENTREVISTA 08}

E: Então vamo lá, me explica o que você fez na letra A.

A: É que você explicou, aí bateu a lembrança.

E: Certo. Aí eu expliquei que tinha que multiplicar.

A: É, aí eu lembrei mais ou menos como fazia, mas fiquei na dúvida. Geralmente as questões de Matemática tem que ter um exemplo pra eu poder seguir.

E: Entendi.

A: Aí conforme eu vou fazendo, aí eu entendo. Só que quando não dão um exemplo, eu não consigo fazer, aí bate um bloqueio.

E: E se o exemplo não tem nada a ver com o que você vai fazer, você não consegue?

A: Não consigo.

E: Se for muito diferente.

A: Não, tenho um bloqueio. Sempre aconteceu isso.

E: Tá bom, então só tenta me explicar aí o que você fez na letra A.

\section{ENTREVISTA 09}

E: E esse 2 aqui que passou daqui pra cá, ele troca o sinal?

A: Acho que aqui não.

E: Não? Por que não?

A: Não sei, quando a professora me ensinou, ela que ensinou que tipo, aqui era só pra multiplicar sabe... só pra multiplicar não, só pra dividir, então não precisava, eu acho, mudar o sinal.

E: Tá, entendi. E nesse daqui? Na letra B. 
Muitas vezes o professor interfere sem perceber que está prejudicando o aluno. Foi o que aconteceu nesses últimos exemplos, em que o aluno só saberia resolver com o auxílio ou com um exemplo do professor. Em sala de aula, eu ouço muito a frase "mas com você fazendo parece tão fácil”. Essa frase simboliza o Efeito Topázio, pois o exercício parece facilitado devido ao fato de o professor tirar algumas conclusões pelos alunos.

\section{Mesmo erro com raciocínios diferentes}

Alguns alunos resolveram o item D $\left(\frac{2 x+1}{3}-\frac{3 x+2}{5}=2\right)$ de maneira similar e errada, chegando ao resultado $x=\frac{15}{2}=7,5$. Qualquer professor, ao observar a resolução escrita desses alunos, imaginaria que se trata de algo elaborado em conjunto ou até mesmo copiado. Porém, os alunos estavam em salas diferentes e, ao entrevistá-los, é possível ver que tiveram raciocínios diferenciados para resolver a questão. Isso mostra o quanto é importante o professor conseguir dialogar com o aluno para entender seu pensamento e seu erro. Seguem dois exemplos.

\section{ENTREVISTA 04}

E: Isso. E o que é que aconteceu pra próxima linha?

A: Eu fiz $x$... deixa eu ver... aqui deu é, 10 vezes o 5... não. O 10 com 5 que deu 15 e o 9 mais o 6 que deu 15 também, aí eu coloquei o 15 aqui dividindo por 2 porque vai dar 15 os dois.

E: Tá, e aí por que dividido por 2? Esse 2 tá multiplicando?

A: Porque... não, agora você me pegou.

E: Agora tô te confundindo? (Risadas)

A: Eu acho que esse aqui passa multiplicando... não, dividindo.

E: Não lembra?

A: Não.

E: Você juntou o $10 x+5$ deu $15 x$ e o $9 x+6$ deu $15 x$ também. Só que o problema é que você só pode juntar $x$ com $x$ e número sem $x$, com número sem $x$. Se juntar o $10 x \operatorname{com} 9 x$ e o 5 com o 6 . E aí continua a equação. Tá?

A: Entendi agora.

\section{ENTREVISTA 08}

E: Por que você colocou todo mundo sobre 15 ?

A: Porque você tinha falado que precisa tirar o MMC, aí como eu fiz o MMC, 
deu 15 , mas eu tinha ficado em dúvida se tinha que tirar o 15 e colocar como fração ou não.

E: Tá. Aí por que mudou o número de cima?

A: Aí ficou tudo muito confuso.

E: Por que aqui o $2 x$ virou $10 x$ ?

A: Porque eu multipliquei.

E: Por quanto?

A: Por 5. E esse aqui por 3.

E: Por quê?

A: Porque você tinha falado do MMC.

E: E aí o que aconteceu pra próxima linha?

A: Aí que... eu consegui fazer essa metade certinho, aí depois...

E: Não disse que tá errado, quero saber o que é que aconteceu aí. Por que é que ficou 15 sobre 2 ?

A: É que eu tava em dúvida como ficava embaixo, se não tinha que ter uma conta, aí acabou ficando assim. Aí como eu fiz a conta na calculadora, deu 7,5.

E: Você esqueceu de me dizer de onde veio o 15 sobre 2 . O resto tudo você esqueceu? Só sobrou o 15 e o 2 ?

A: É, então, por causa disso. Eu não sabia da onde vinha, aí eu acabei fazendo desse jeito.

E: Aí você inventou alguma coisa pra ter uma resposta?

A: Não é que eu inventei, é que eu ia deixar só a primeira, aí eu me foquei na de baixo, aí não dá certo. Eu me dou melhor nas outras matérias e meu irmão caçula faz conta de cabeça.

\section{Comentários interessantes dos alunos}

Infelizmente, alguns dos alunos entrevistados demonstraram desinteresse, o que prejudicou a entrevista, como pode ser observado no caso a seguir.

ENTREVISTA 09

E: Quer tentar fazer agora?

A: Não, não precisa não.

E: Tenta aqui embaixo.

A: Esse $x^{2}$ ele também conta, né?

E: Lógico.

A: Você vai me confundir.

E: Eu não vou te confundir, não tô falando nada. 
A: Tá sim.

E: Como eu vou te confundir sem falar nada?

A: Porque você ficou assim.

E: Só por que eu tô olhando você fazer?

A: Aí agora aqui tá negativo, eu vou passar positivo, sei lá porque mas eu vou.

E: Sei lá porque é ótimo.

A: Eu não lembro como é o $x^{2}$, ele fica $1-1 x^{2}$ ?

E: Não sei.

A: Ai como você é chata, não tem ninguém vendo.

E: Mas eu quero saber como você faria. Se eu te contar perde a graça.

A: Porque quando não tem aquele fica 1 também? Eu não sei, eu não sei se vai ficar $x^{3}$, tem $x^{3}$ ?

E: Existe.

A: Mas eu vou coloca, né? Aqui fica 6, aí fica $x$ igual à 6. Eu não sei o que eu faço com esse 3, então vai ficar assim, tá?

E: Tá bom.

Outros apenas reproduzem o que já viram em alguma outra resolução ou que tenha sido dito pelo professor.

\section{ENTREVISTA 08}

A: Eu sempre tive problema com sinal, sempre me confundo. Eu sempre tenho anotado, toda vez que o professor passa lição ou matéria nova, enquanto ela tá explicando eu vou fazendo anotação porque senão eu me perco, em qualquer matéria.

E: Entendi.

A: O que vai número e conta eu acabo me perdendo, eu tenho que fazer anotação. Mesmo em Português, que eu vou melhor, eu faço anotação.

$[\ldots]$

A: Esse é o problema pra mim quando eu faço alguma coisa tem que ter um exemplo de Matemática, pra mim poder seguir, pra mim poder acertar. Mas eu acho que eu melhorei um pouco em Matemática. Então minhas notas sempre foram ruins em Matemática, tanto que eu tenho dificuldade em Física porque tem que fazer conta.

\section{ENTREVISTA 09}

E: E esse 2 aqui, que passou daqui pra cá, ele troca o sinal? 
A: Acho que aqui não.

E: Não? Por que não?

A: Não sei, quando a professora me ensinou, ela que ensinou que tipo, aqui era

só pra multiplicar sabe... só pra multiplicar não, só pra dividir, então não

precisava, eu acho, mudar o sinal.

Alguns alunos têm pouca familiaridade com a linguagem matemática, comprovando, mais uma vez, que em sala de aula eles apenas reproduzem o que está sendo feito por colegas ou pelo professor. Observe-se:

\section{ENTREVISTA 12}

A: A mesma coisa. Aqui quando não tem nada é 1-6, aí aqui mesma coisa igual à zero. Coloquei as letras de um lado, os números pro outro.

E: E os parênteses? Eles servem pra quê?

A: Pra separar.

E: Só separar? O que é que tem entre um parênteses e outro?

A: Um vezes?

E: É, um vezes. E como que você faz essa conta de vezes?

A: Seria aqui, né?

E: Você não fez a conta de vezes, né? Como será que teria que fazer?

A: Teria que fazer... não sei. Seria esse vezes esse e esse vezes esse?

E: Isso. Quer tentar fazer? Vamo tentar fazer aqui embaixo.

\section{ENTREVISTA 06}

E: Mas aí não é multiplicação?

A: Isso.

E: Não é 5 vezes 1 ?

A: Exatamente. Daí ficou 5 vezes 1 ficou 6 e 5 vezes $x$ ficou $5 x$.

E: Quando você faz 5 vezes $1 \ldots$ imagina 5 vezes o 1 , é fazer o $1+1+1+1+1$.

A: É, era pra ter dado 5.

E: É, era pra dar 5. Porque na realidade você somou, você fez 5 mais 1.

A: É.

ENTREVISTA 09

E: Entendi. E aqui, quando você fez 1 dividido por 1, vai dar 0 ? 1 dividido por -1 ? 
A: Dá, não dá? Porque você tá devendo -1. Sei lá. 


\subsection{CONCLUSÕES PARCIAIS}

Observando as resoluções dos alunos e a explicação dos raciocínios por parte de alguns, pode-se perceber que, de fato, os erros cometidos com maior frequência são relativos à generalização de regras, à aprendizagem prévia deficiente e à dificuldade na linguagem.

A linguagem matemática é de difícil entendimento para os alunos entrevistados. Muitos não sabem quando somar ou não somar termos de uma expressão polinomial, outros têm dificuldade com o uso dos parênteses e ainda há aqueles que nem sequer entendem o conceito de equação, pois o símbolo de igual desaparece no meio do processo.

Muitos alunos apenas reproduzem o que lhes foi passado, sem entender o real motivo de aquela operação se fazer necessária. Assim, acabam assimilando apenas algumas regras como "troca de lado e inverte o sinal" ou "menos com menos dá mais" para facilitar a resolução em determinadas situações. Sendo assim, os processos utilizados acabam se tornando puramente mecânicos, o que gera erros e permite generalizações equivocadas.

Alguns alunos não se mostram interessados em aprender ou curiosos com os motivos que levaram aquele método a ser utilizado, focam apenas em dar respostas corretas e esperadas pelo professor. E o professor acaba antecipando o resultado muitas vezes por falta de tempo ou por achar que o aluno não conseguiria concluir por conta própria.

Existem também os casos em que os alunos não acreditam serem capazes, alguns por se cobrarem demais e outros por utilizarem isso como desculpa para suas falhas e insucessos.

E ainda existem casos em que os alunos tiveram resoluções iguais, porém raciocínios diferentes, o que é um indício de que uma avaliação escrita pode não ser o melhor método para medir o que o aluno sabe ou não. Percebe-se o quanto é importante que o professor tenha a oportunidade de acompanhar de perto o raciocínio desenvolvido pelos alunos. 


\section{CONCLUSÕES GERAIS}

Após a análise realizada, é possível concluir que os alunos do Ensino Médio realmente têm muita dificuldade em aplicar alguns conceitos do Ensino Fundamental. Muitas vezes trata-se de um conceito errado ou uma regra somente memorizada em vez de absorvida e entendida. Sendo assim, de fato, os maiores erros são relativos à generalização de regras, à aprendizagem prévia deficiente e à dificuldade na linguagem, conforme classificação mencionada na página 37.

Por exemplo, nas operações com frações, alguns alunos só calcularam o MMC porque sabiam que, quando tem fração envolvida na operação, isso deve ser feito; porém, o conceito de frações equivalentes se perdeu. Assim como, ao trabalhar com equações, os alunos enfatizaram que, quando um termo muda de lado na equação, este deve trocar o sinal, sem entenderem o significado da igualdade. Também é possível incluir aqui as "regras de sinais" decoradas pelos alunos e, algumas vezes, indevidamente generalizadas.

Para reduzir esse tipo de erro, minha sugestão seria entender a necessidade que os professores que introduzem esses conteúdos no Ensino Fundamental têm de criar esses "materiais" que, supostamente, deveriam auxiliar na transposição didática, mas que acabam atrapalhando algumas vezes. Como são frases prontas e decoradas para alguns casos específicos, talvez fosse mais eficaz criar algo que generalizasse os casos e realmente expressasse a regra envolvida. Por exemplo, ao invés de "passa para o outro lado e troca o sinal", poderia ser empregado "passa para o outro lado e inverte a operação". Essa regra seria igualmente eficaz nos casos em que a antiga se aplica (adição e subtração), mas também serviria para outras operações envolvidas na resolução de uma equação (multiplicação e divisão).

Para fazer com que os alunos entendessem o motivo e significado da utilização dessas regras, poderiam ser feitos trabalhos nos quais o aluno deveria descobrir o problema. Ele partiria de um resultado considerado correto e chegaria a um absurdo, tendo, então, que encontrar o problema da sua resolução. Até chegar o momento em que os próprios alunos concluiriam o desejado pelo professor e sentiriam necessidade de criar um método para auxiliar na resolução dos problemas propostos. O papel do professor, neste caso, seria o de mediar a relação entre o aluno e o conhecimento, sem interferir, deixando que este tire suas próprias conclusões e construa o seu conhecimento matemático. 
Foi possível ver também que o aluno emprega resoluções conhecidas e confortáveis em outras novas, muitas vezes, erradamente. É importante que o professor tenha conhecimento de como o aluno está pensando e proponha novos desafios, em que a técnica anteriormente utilizada não se aplica. Isso também é visto quando o aluno reproduz o que o professor fez em sala de aula. Dessa forma, ele somente sabe resolver o problema de uma determinada maneira, sem ter, de fato, assimilado o conteúdo trabalhado.

Muitos alunos entrevistados ficaram com receio de dizer o que pensavam por medo de estarem errados e serem repreendidos. Isso ocorre porque o professor costuma apontar os erros dos alunos, indicando o que ele não sabe. Assim, o aluno acaba não sabendo lidar com o erro e não o considera como algo habitual. Porém, acredito que, fazendo várias vezes errado, o aluno aprende muito mais do que fazendo uma única vez correto, tornando o erro parte integrante do processo de aprendizagem.

E as avaliações? São boas técnicas para identificar o que o aluno sabe ou não? Foram vistas aqui duas resoluções idênticas do mesmo exercício, porém com raciocínios diferentes. Também foi possível notar que alguns alunos que aplicaram um procedimento corretamente, muitas vezes não sabiam explicar o que haviam feito (como foi o caso do MMC). Isso ocorreu porque as resoluções escritas não demonstram o que os alunos realmente compreenderam. Sendo assim, é importante o professor tentar entender a lógica do aluno através de uma argumentação sobre sua resolução. Porém, para que isso funcione, é necessário um esforço de ambas as partes, pois, ao mesmo tempo em que o professor deve entender o erro do aluno, o aluno deve querer entendê-lo para aprimorar seu conhecimento.

Portanto, após analisar os questionários e as entrevistas, pude ver que a prática docente de análise de erros pode acrescentar argumentos importantes à produção escrita do aluno. E assim, o professor pode traçar um melhor perfil da turma e elaborar uma transposição didática que melhor se aplique. Este recurso, além de dar mais elementos ao professor, também mostra aos alunos que o professor se preocupa e está atento aos problemas enfrentados por suas turmas.

Uma das formas de fazer essa análise é o diálogo individual, como foi feito aqui, que permite que o professor observe detalhes ocultos nas resoluções. Porém, não é a única maneira. Essa conversa pode ser feita com a turma, ou até mesmo entre os próprios alunos para que os 
colegas se ajudem. Se não for possível, vale a pena ao menos contabilizar os erros para detectar em que os alunos mais estão errando e tentar reforçar este conteúdo.

Considero, então, que os professores e as instituições de ensino deveriam tentar incluir em seu currículo mecanismos em que a análise de erros fosse valorizada e pudesse de fato ocorrer, pois o ganho seria imensurável. 


\section{REFERÊNCIAS BIBLIOGRÁFICAS}

AVILA T. P. e SANTIAGO R. A. A aprendizagem matemática no Ensino Fundamental e o seu impacto no Ensino Médio. Anais do Encontro de Produção Discente PUCSP/Cruzeiro do Sul. São Paulo, 2012.

BARROSO, M. M. e FRANCO V. S. Obstáculos epistemológicos e didáticos: concepções teóricas e práticas de professores no uso de materiais manipuláveis. Campo Mourão, Anais do V Encontro Interdisciplinar de educação, 2013.

BARUFI, M. C. B. A construção / negociação de significados no curso universitário inicial de Cálculo Diferencial Integral. São Paulo, Tese de Doutorado na Universidade de São Paulo, 1999.

BORASI, R. Reconceiving Mathematics Instruction: A Focus on Errors. New Jersey, 1996.

BROUSSEAU, G. Introdução ao estudo da teoria das situações didáticas: conteúdos e métodos de ensino. Tradução de Camila Bogéa. São Paulo, Ática, 2008.

CARNERO, V. C. G. Engenharia didática: um referencial para ação investigativa e para formação de professores de Matemática. Artigo da Revista Zetetiké da Faculdade da Educação da Universidade Estadual de Campinas, vol. 13 - núm. 23, 2005.

CURY, H. N. Análise de erros. Salvador, Anais do X Encontro Nacional de Educação Matemática, 2010.

CURY, H. N. Análise de erros: o que podemos aprender com a resposta dos alunos. Belo Horizonte, Autêntica, 2013.

CURY, H. N. As concepções de Matemática dos professores e sua forma de considerar o erro dos alunos. Porto Alegre, Tese de Doutorado na Universidade Federal do Rio Grande do Sul, 1994.

CURY, H. N. e KONZEN, B. Classificação e análise de erros em álgebra. Caxias do Sul, Anais do IX Encontro gaúcho de Educação Matemática, 2006. 
CURY, H. N. e KONZEN, B. Uma aplicação de jogos na análise de erros em educação Matemática. Santa Catarina, Artigo da Revista Eletrônica de Educação Matemática, vol. 2.6, 2007.

CURY, H. N., BISOGNIN, V. e BISOGNIN, E. A análise de erro com metodologia de investigação. In: ProfMat2009, Viana do Castelo, Anais APM, 2009.

D’AMORE, B. Elementos de Didática da Matemática. Tradução de Maria Cristina Bonomi. São Paulo, Editora Livraria da Física, 2007.

ELBRINK M. Analyzing and Addressing Common Mathematical Errors in Secondary Education. Dissertação de Mestrado em Ball State University, 2008.

FREITAS, M. A. de. Equações do $1^{\circ}$ grau: Métodos de resolução e análise de erros no Ensino Médio. São Paulo, Dissertação de Mestrado em Educação Matemática na Pontifícia Universidade Católica, 2002.

GOMEZ H. C. M. Reflexões sobre uma prática de ensino: Uma Engenharia Didática. Porto Alegre, Trabalho de Conclusão de Curso de Licenciatura em Matemática pela Universidade Federal do Rio Grande do Sul, 2008.

IMBERNÓN, F. Formação continuada de professores. Tradução de Juliana dos Santos Padilha. Porto Alegre, Artmed, 2010.

IMBERNÓN, F. Inovar o ensino e a aprendizagem na Universidade. Tradução de Silvana Cabucci Leite. São Paulo, Cortez, 2012.

MACHADO, N. J. e CUNHA M. O. Lógica e linguagem cotidiana - verdade, coerência, comunicação, argumentação. Belo Horizonte, Autêntica, 2005.

MACHADO, N. J. Educação: competência e qualidade. São Paulo, Escrituras, 2010.

MACHADO, N. J. Educação: projetos e valores. São Paulo, Escrituras Editora, 2000.

MACHADO, N. J. Epistemologia e didática: as concepções de conhecimento e inteligência e a prática docente. São Paulo, Cortez, 2005. 
MACHADO, N. J. Matemática e Educação: alegorias, tecnologias, jogo, poesia. São Paulo, Cortez, 2012.

MACHADO, N. J. Matemática e Língua Materna: análise de uma impregnação mútua. São Paulo, Cortez, 2011.

MIRANDA W. S. Erros e obstáculos: os conteúdos Matemáticos do Ensino Fundamental no Processo de Avaliação. Belém, Dissertação de Mestrado na Universidade Federal do Pará, 2007.

MORAES, F. R. Um estudo sobre erro na resolução de equações do $1^{o}$ grau com o software APLUSIX. Campo Grande, Dissertação de Mestrado em Educação Matemática da Universidade Federal do Mato Grosso do Sul, 2013.

OLIVEIRA, J. L., ARRUDA, A. M., SILVA, F. C. e CAMARGO, J. A. Os conceitos de erro, obstáculo e contrato didático segundo Guy Brousseau. Santa Maria, Anais da III Escola de Inverno de Educação Matemática - 1 Encontro Encontro Nacional do PIBID Matemática, 2012.

PAIS, L. C. Didática da Matemática: Uma análise da influência francesa. Belo Horizonte, Autêntica, 2001.

PERRENOUD, P. A Pedagogia na Escola das Diferenças: fragmentos de uma sociologia do fracasso. Tradução de Cláudia Schilling. Porto Alegre, Artmed, 2001.

PERRENOUD, P. Ensinar: agir na urgência, decidir na incerteza. Tradução de Cláudia Schilling. Porto Alegre, Artmed, 2001.

PIBID. Programa Institucional de Bolsa de Iniciação à Docência. Capes. 2014. Disponível em: <http://www.capes.gov.br/educacao-basica/capespibid> Acesso em: 09 ago. 2014.

PINTO, N. B. Concepções de erro: nas ciências e no Ensino Fundamental de Matemática. Curitiba, Anais da XII Educere, 2005.

PINTO, N. B. O erro com estratégia didática: Estudo do erro no ensino da Matemática Elementar. Campinas, Papirus, 2000. 
PISA. Programme for international student assessment. Inep. 2013. Disponível em: <http://download.inep.gov.br/acoes_internacionais/pisa/resultados/2013/country_note_brazil_pisa _2012.pdf> Acesso em: 09 ago. 2014.

RADATZ, H. Error Analysis in Mathematics Education. Journal for Research in Mathematics Education, vol. 10 - núm. 3, pg.163 a 172, 1979.

RAMOS M. L. P. D. Dificuldades e erros de alunos do $1^{\circ}$ ano da educação profissional tecnológica de nível médio em Matemática: reflexões e desafios. Rev. Prod. Disc. Educ. Matem. São Paulo, 2014.

SANTOS, V. de M. et al. Ensino de Matemática na escola de nove anos: dúvidas, dívidas e desafios. São Paulo, Cengage Learning, 2014.

SARESP, Sistema de Avaliação de Rendimento Escola do Estado de São Paulo - Relatório Pedagógico. Disponível em: <http://www.educacao.sp.gov.br/consulta-saresp.html> Acesso em: 08 jun. 2015.

SPERAFICO, Y. L. S. e GOLBERT C. S. Análise de erros na resolução de problemas envolvendo equações algébricas do $1^{\circ}$ grau. Florianópolis, Artigo da IX Anped Sul - Seminário de Pesquisa em Educação da Região Sul, 2012.

TAFNER, M. A construção do conhecimento segundo Piaget. Disponível em: < http://www.cerebromente.org.br/n08/mente/construtivismo/construtivismo.htm> Acesso em 31 mai.2015.

TEIXEIRA L. R. M. A análise de erros: uma perspectiva cognitiva para compreender o processo de aprendizagem de conteúdos matemáticos. Presidente Prudente, Artigo da Revista Eletrônica Nuances do Programa de Pós-Graduação em Educação e do Departamento de Educação da Faculdade de Ciências e Tecnologia da UNESP, vol. 3, pg. 47 a 52, 1997.

TEIXEIRA L. R. M. e AMBROSIO A. C. S. O tratamento dado ao erro em classes de recuperação intensiva: o caso de um professor de Matemática. Presidente Prudente, Encontro de Ensino, Pesquisa e Extensão, 2013. 
TEIXEIRA P. J. M. e PASSOS C. C. M. Um pouco da Teoria das Situações Didáticas de Guy Brousseau. Campinas, Artigo da Revista Zetetiké da Faculdade da Educação da Universidade Estadual de Campinas, vol. 21 - núm. 39, 2013.

VILELA, A. L. Sobre a didáctica das Matemáticas. Lisboa, Cadernos da Seara Nova, 1937.

VINNER, S., HERSHKOWITZ R. e BRUCKHEIMER M. Some Cognitive Factors as Causes of Mistakes in the Addition of Fractions. Journal for Research in Mathematics Education, vol. 12 núm. 1, pg.70 a 76, 1981. 


\section{APÊNDICES}

\subsection{PRIMEIRO QUESTIONÁRIO}

Olá, meu nome é Ana Luiza e sou aluna do Mestrado Profissional em Ensino de Matemática da USP. Estou fazendo uma pesquisa sobre a forma de resolução de alguns exercícios e a possível existência de dificuldades na resolução deles. A seguir proponho alguns exercícios e gostaria de que você os resolvesse passo a passo. É importante, portanto, que as respostas dadas sejam as mais completas possíveis, no sentido de retratarem todas as dificuldades que sinta ter e de expressarem o raciocínio feito para chegar às respostas dos problemas. Não se preocupe em tentar fornecer respostas "boas", "corretas" ou "esperadas". O que eu vou analisar não é o resultado final, mas sim o processo e até mesmo, os erros. Caso você não consiga alguma parte, por favor, tente escrever o motivo e passe para a questão seguinte. É importante que você saiba que poderei utilizar esses resultados na minha dissertação. Embora eu não vá citar nomes, compreendo se você não quiser responder, por não se sentir à vontade.

\section{$\underline{\text { Exercícios }}$}

1. Calcular, se possível, o valor das expressões aritméticas a seguir.
a) $(-6+4) \cdot(-1-3)+2 \cdot(-8+3)-(7+3) \div(3-5)$
b) $(-2)^{2}+(-2)^{3}-2^{2}-2^{3}$
c) $\frac{1-\frac{1}{2}}{\frac{3}{4}}+\frac{1}{3}$
d) $\frac{3}{4+5-9+7-3-4}$

2. Determinar, se possível, o valor de $a$ em cada caso.
a) $3 a+5=5(a+3)$
b) $a^{2}-4 a+2=0$ 


\subsection{SEGUNDO QUESTIONÁRIO}

Olá, meu nome é Ana Luiza e sou aluna do Mestrado Profissional em Ensino de Matemática da USP. Estou fazendo uma pesquisa sobre a forma de resolução de alguns exercícios e a possível existência de dificuldades na resolução deles. A seguir proponho alguns exercícios e gostaria de que você os resolvesse passo a passo. É importante, portanto, que as respostas dadas sejam as mais completas possíveis, no sentido de retratarem todas as dificuldades que sinta ter e de expressarem o raciocínio feito para chegar às respostas dos problemas. Não se preocupe em tentar fornecer respostas "boas", "corretas" ou "esperadas", pois irei analisar todo o processo, incluindo os erros. É importante que você saiba que poderei utilizar esses resultados na minha dissertação, mas sua identificação será mantida em sigilo. Desde já, muito obrigada!

Exercício: Resolver as equações a seguir.
a) $3(x+1)=x-1$
b) $x-3=5(x+1)$
c) $9-4 x=3-2 x+4$
d) $\frac{2 x+1}{3}-\frac{3 x+2}{5}=2$
e) $x+1=\frac{x-2}{4}$
f) $x+1=\frac{x}{2}+4$
g) $(x-3)(x+1)=0$
h) $(x+1)(x+2)=6$ 


\section{ANEXOS}

\subsection{QUESTIONÁRIOS DOS ALUNOS ENTREVISTADOS}

Seguem os 12 questionários dos alunos selecionados para entrevista.

\section{Resolução 01}

a) $3(x+1)=x-1$

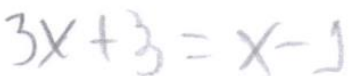

$3 x-x=-1-3$

$2 x=-4$

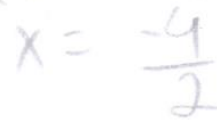

$x=-2$ b) $x-3=5(x+1)$

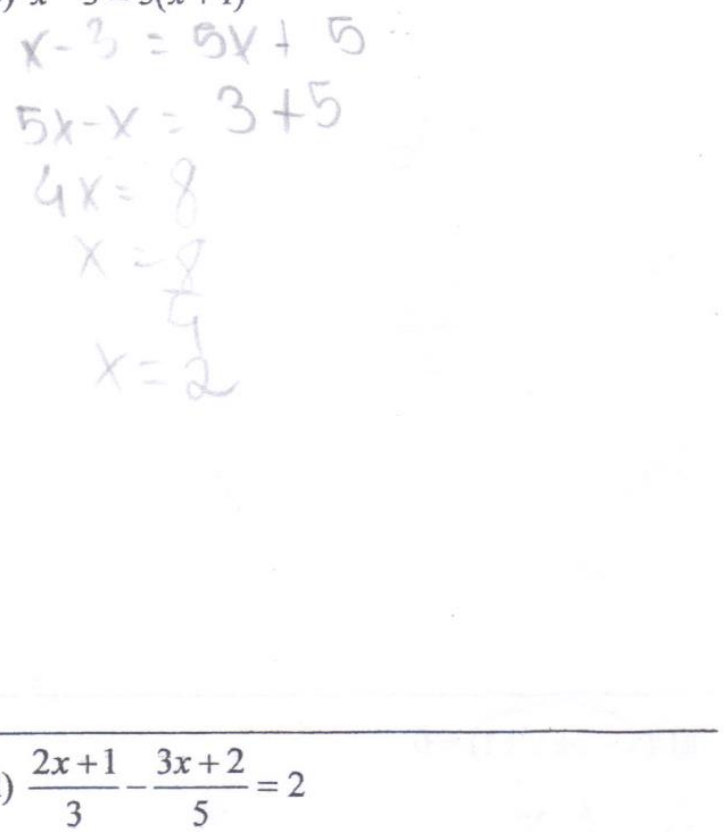

c) $9-4 x=3-2 x+4$

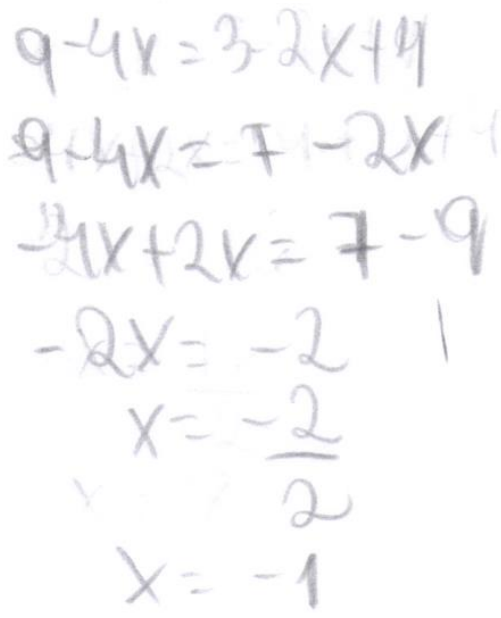

d) $\frac{2 x+1}{3}-\frac{3 x+2}{5}=2$

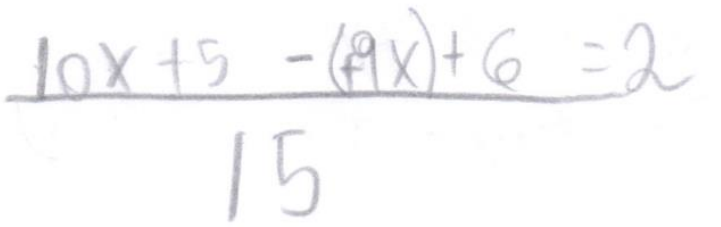


120

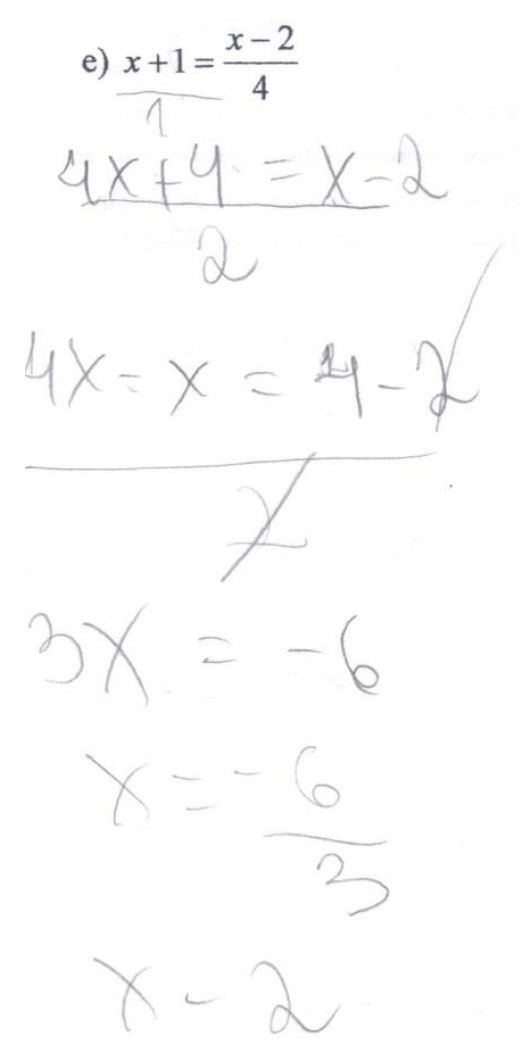

g) $(x-3)(x+1)=0$

$$
\begin{aligned}
& x^{2}+x=-3 x-3 \\
& 2 x^{2}+3 x+x=-3 \\
& 2 x^{2}+4 x=-3
\end{aligned}
$$

f) $x+1=\frac{x}{2}+4$
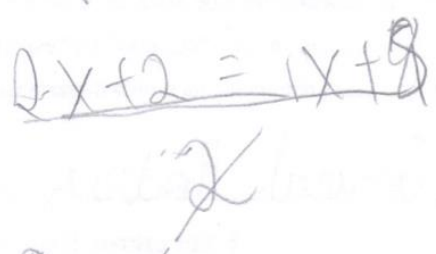

$$
2 x-1 x=-2+8
$$

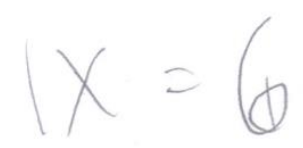

$$
x=6
$$

h) $(x+1)(x+2)=6$ 


\section{Resolução 02}

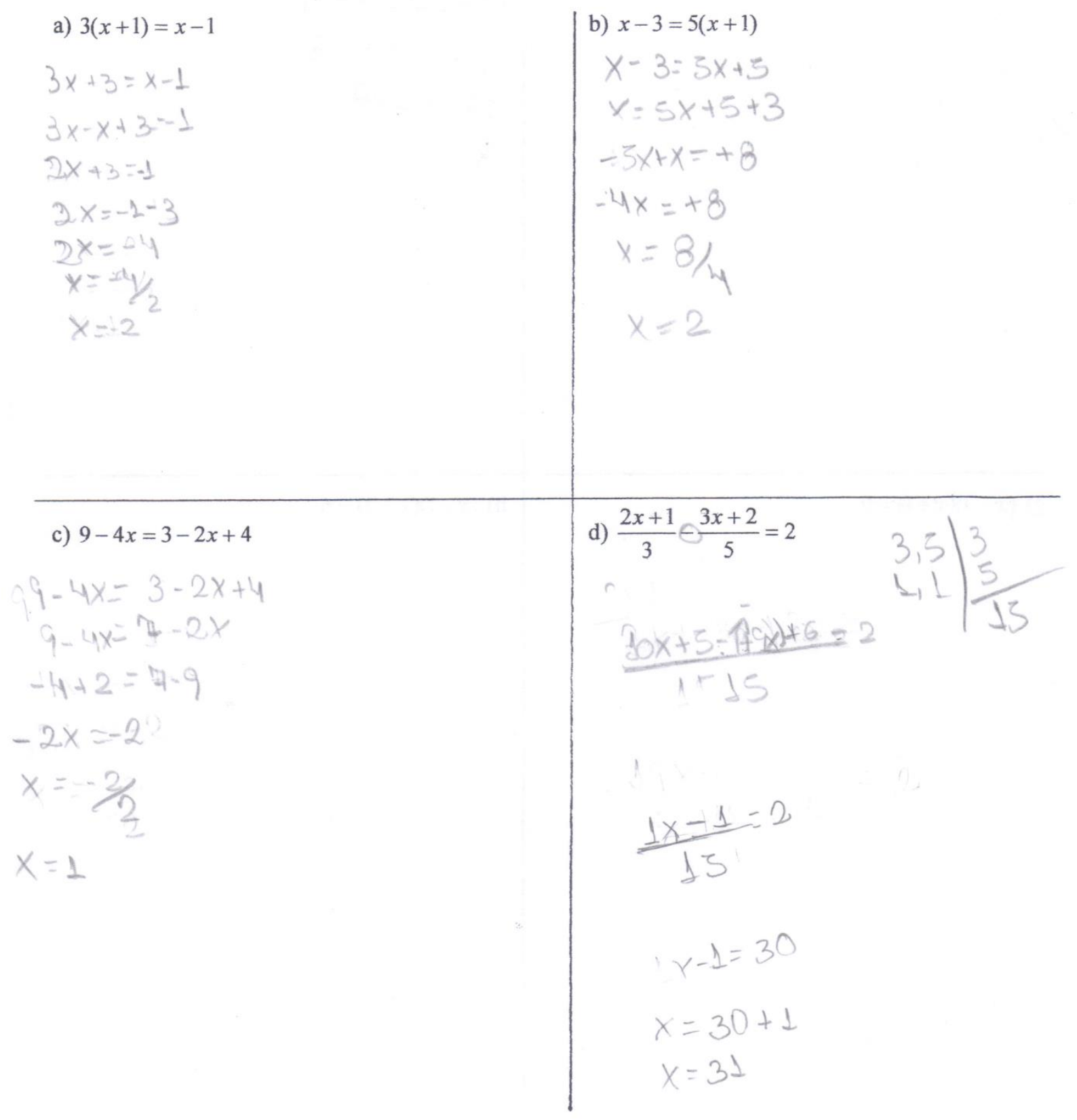




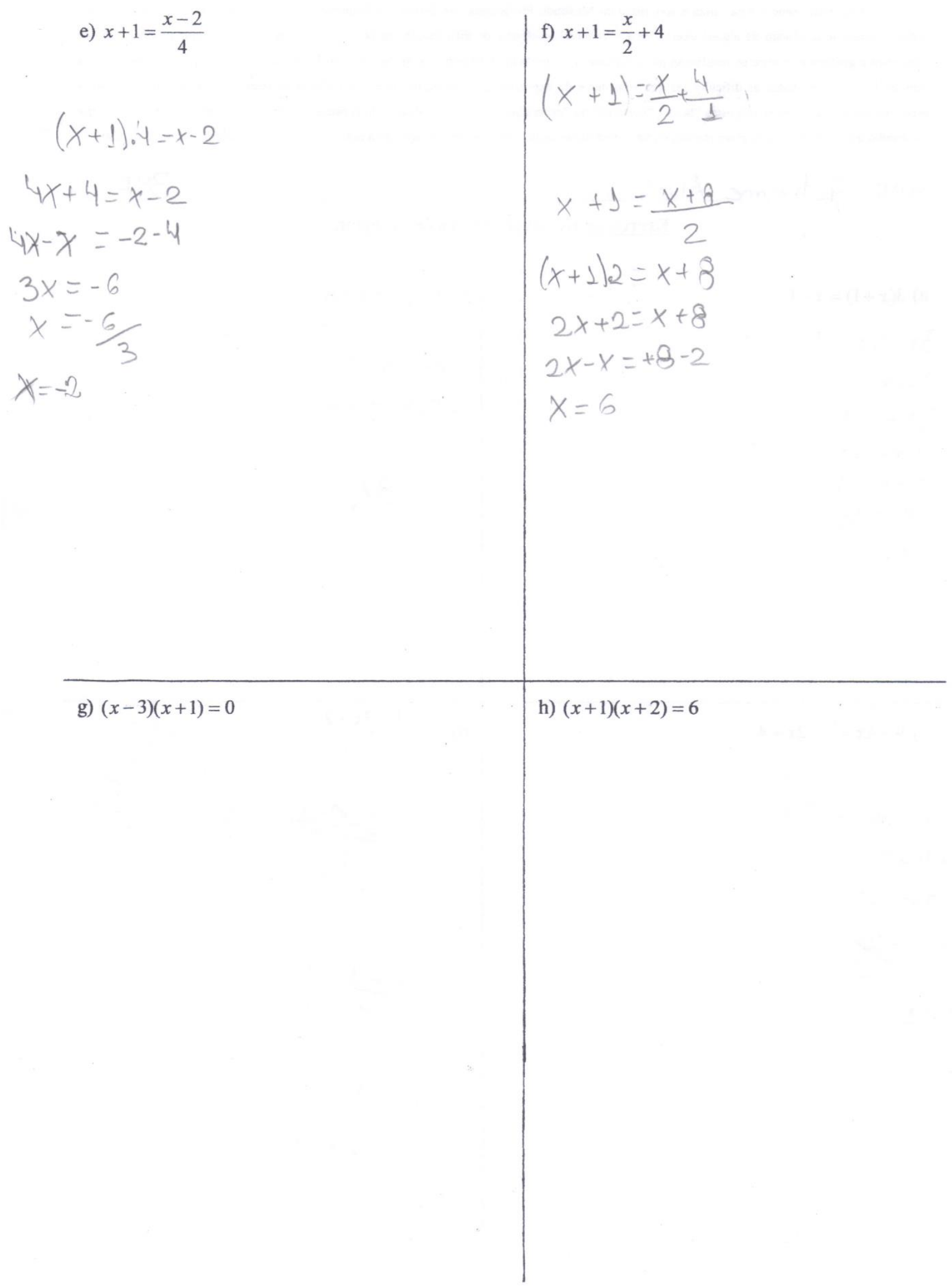




\section{Resolução 03}
a) $3(x+1)=x-1$
b) $x-3=5(x+1)$
$3 x+3=x-x$
$3 x-x=-1-3$
$x-3=5 x+5$
$2 x=-4$
$x=\frac{-4}{2}$
$x=-2$
$x-5 x=5+3$
$-4 x=8$

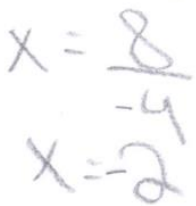
c) $9-4 x=3-2 x+4$
d) $\frac{2 x+1}{3}-\frac{3 x+2}{5}=2$
$y-4 x=3-2 x+4$
$9-3-4=-2 x+4 x$
$\alpha=2 x$
$x=\frac{2}{2}$
$x=8$
$\frac{5(2 x+1)}{15}-\frac{3(3 x+2)}{15}=\frac{15(2)}{15}$
$10 x+5-9 x-6=30$
$10 x-9 x=30-5-6$
$x=s 9$ 
124

$$
\begin{aligned}
& \text { e) } x+1=\frac{x-2}{4} \\
& \frac{x+1}{4}=\frac{x-2}{4} \\
& \begin{array}{l|l}
1,4 & 2 \\
3,2 & 2 \\
3,3 &
\end{array} \\
& 4(x+1)=x-2 \\
& 4 x+4=x-2 \\
& 9 x-x=-2+4 \\
& 3 x=2 \\
& x=\frac{2}{3} \\
& \begin{array}{l}
\text { f) } x+1=\frac{x}{2}+4 \\
\frac{x+1}{2}=\frac{x}{2}+\frac{9}{2}
\end{array} \\
& 1,1,2,19 \\
& 2(x+1)=x+2(4) \\
& 2 x+2=x+8 \\
& 2 x-x=8-2 \\
& x=6 \\
& \text { g) }(x-3)(x+1)=0 \\
& \text { h) }(x+1)(x+2)=6
\end{aligned}
$$




\section{Resolução 04}

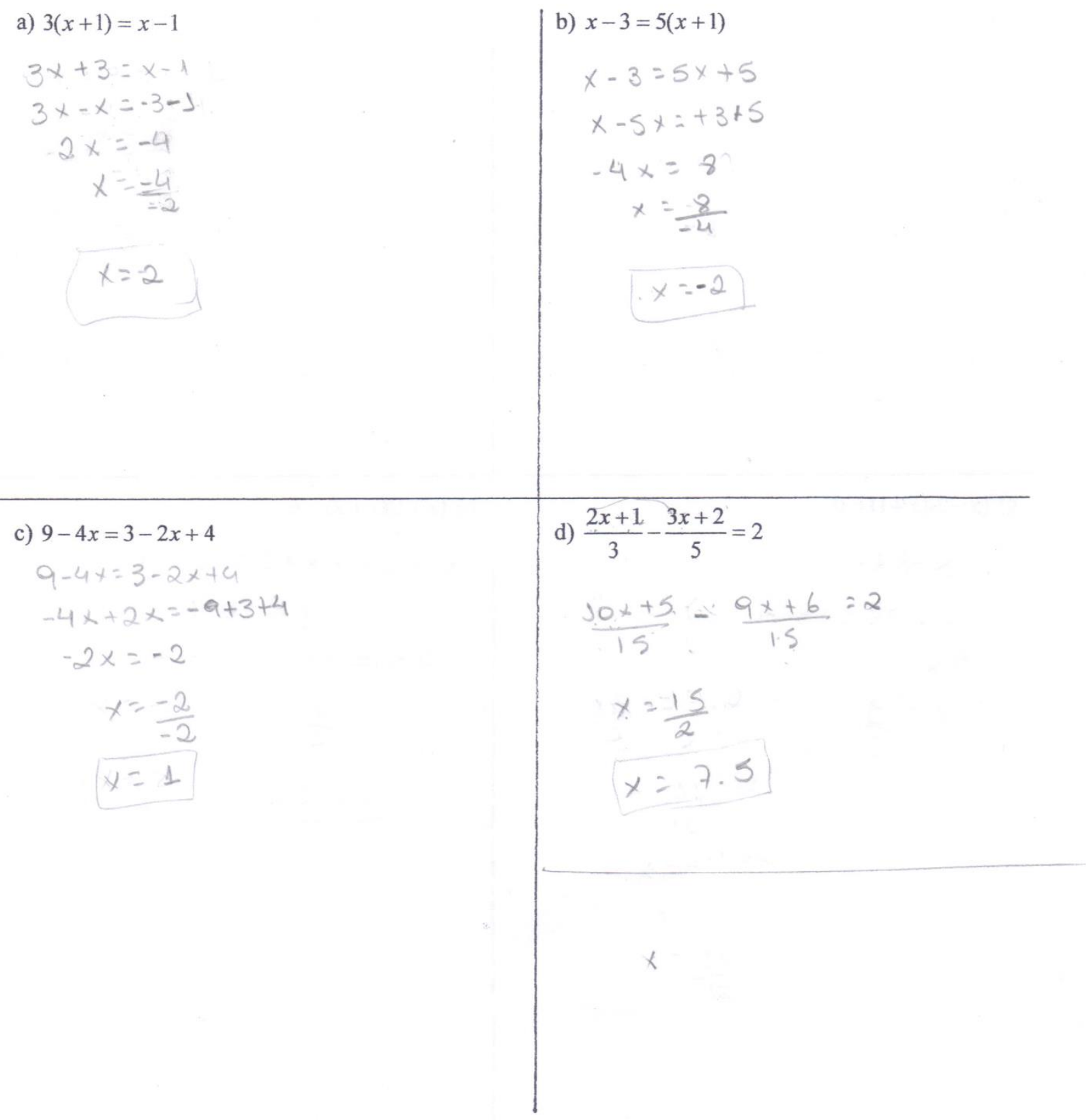




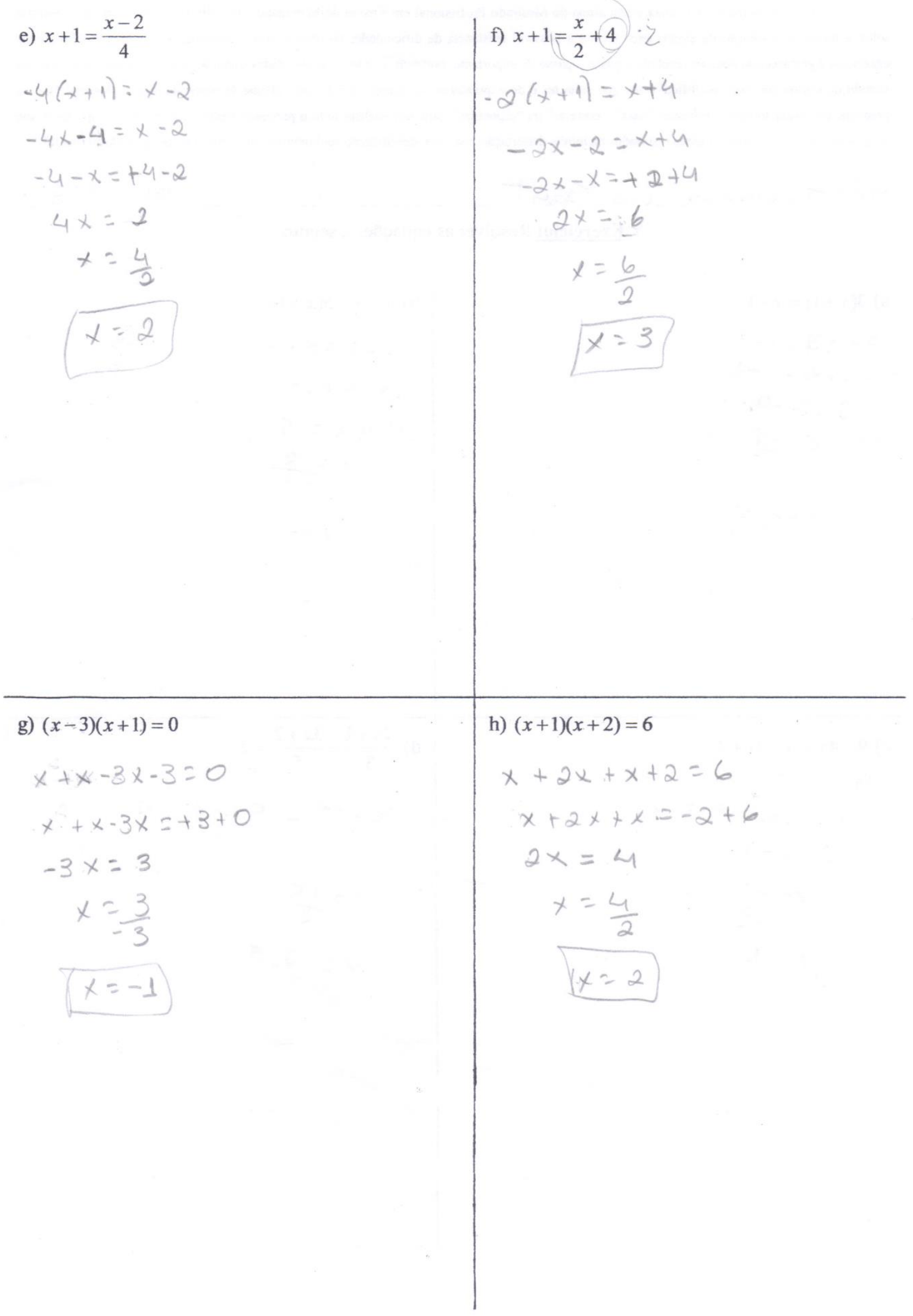




\section{Resolução 05}

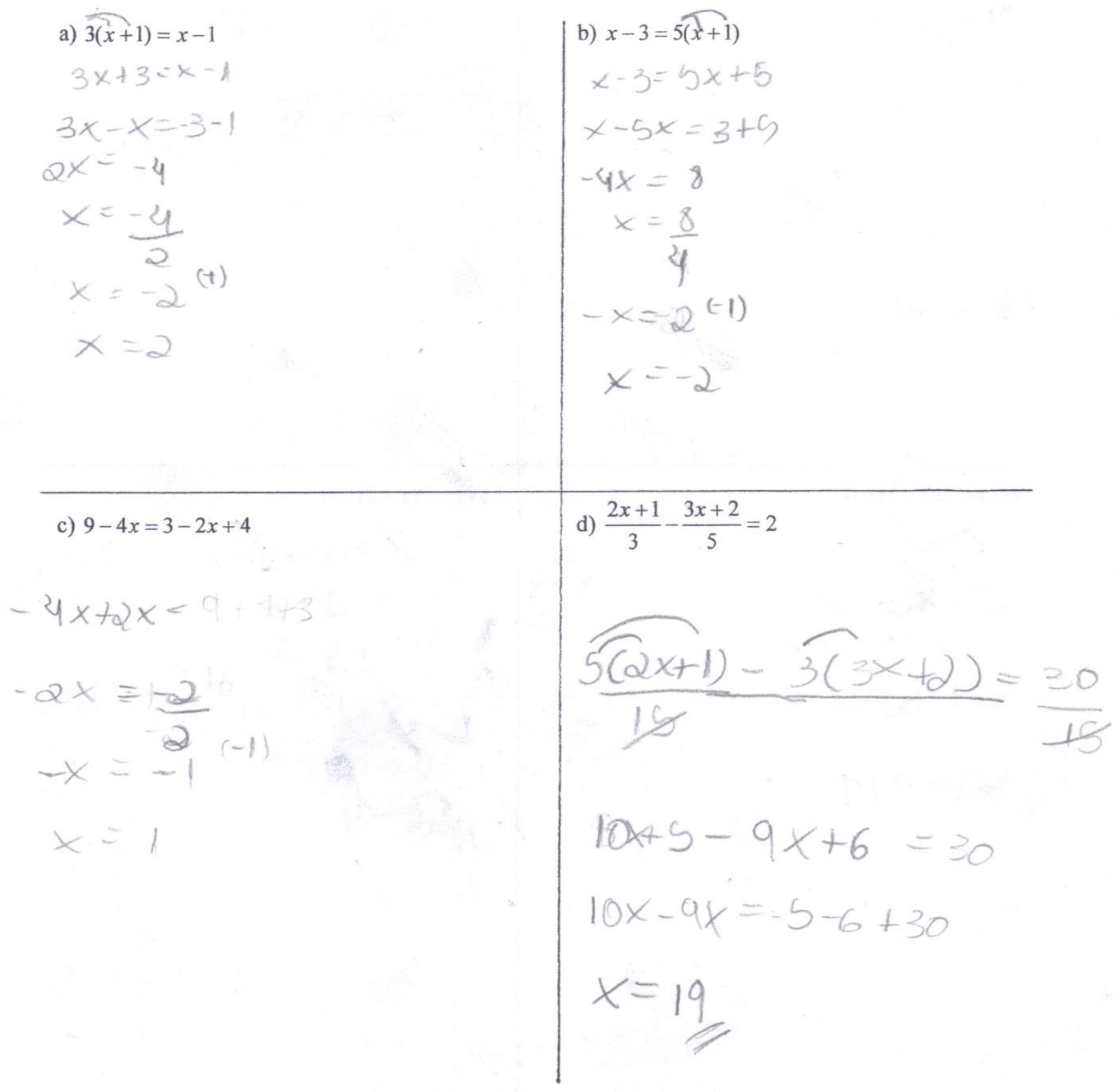


128

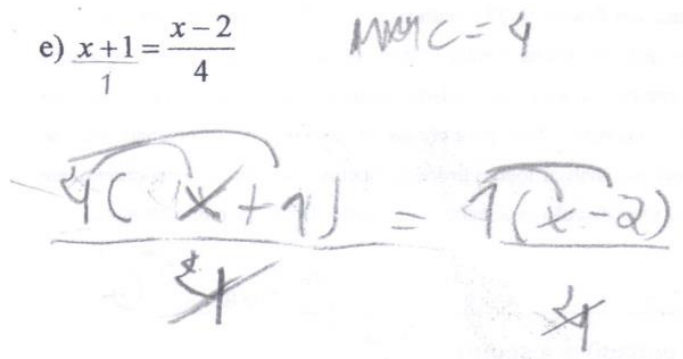

$$
4 x+4=x-22
$$

$1 c$
$3 x=-6$

$x=\frac{-6}{-3}(-1)$

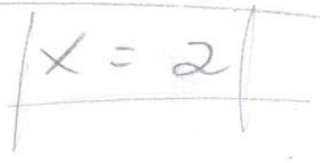

g) $(x-3)(x+1)=0$

$$
\begin{aligned}
& x^{2}-x-3 x-3=0 \\
& x^{2}-2 x-3=0
\end{aligned}
$$

$a=1 \quad b=-2 c=-3-0$

$x=(-2)^{2}-4 \cdot 1 \div-3$

$\Delta=4+12$

$\Delta=\sqrt{16}$

$\lambda=4$

$x=\frac{-6 \pm \sqrt{\Delta}}{2 \cdot a} \quad x_{2}=\frac{2 \pm 4}{2}$

$x_{1}=\frac{2 \pm 4}{2} \quad x_{1}=3$

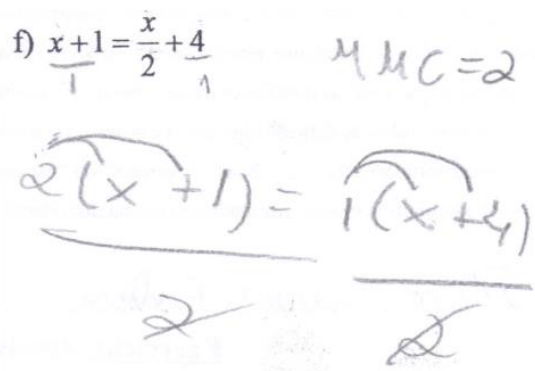

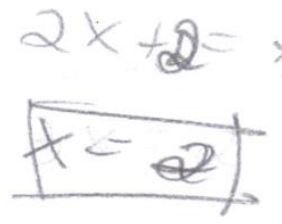

h) $(x+1)(x+2)=6$

$$
\begin{aligned}
& x^{2}+2 x+x+2=6 \\
& x^{2}+3 x+2-6=0 \\
& \Delta=6^{2}-4 \cdot a \cdot c \\
& 3^{2}-4 \cdot 1 \cdot(-4) \\
& \Delta=9+16 \\
& \Delta=\sqrt{25} \\
& \Delta=5 / 11 \\
& x=\frac{-3 \pm 5}{2} \quad x_{2}=\frac{-3-5}{2} \\
& x_{1}=2, \quad x_{2}=\frac{-8}{2}
\end{aligned}
$$




\section{Resolução 06}
a) $3(x+1)=x-1$
$3 x+3=x-1$
$3 x-x=3-1$
$2 x=2$
b) $x-3=5(x+1)$
$x-3=5 x+6$
$x-5 x=6+3$
$4 x=9$
c) $9-4 x=3-2 x+4$
d) $\frac{2 x+1}{3} \times \frac{3 x+2}{5}=2$
$9-4 x=3-2 x+4$

$$
\begin{aligned}
2 x-4 x & =3+4 \\
-2 x & =7-7 \\
-2 x & =\frac{7}{-2}
\end{aligned}
$$$$
7-9
$$$$
2=9 x-58 x+5+6
$$$$
-J x=\frac{11}{2}
$$$$
x=1
$$

$$
\begin{aligned}
& 2=-5 x+11 \\
& +1 x=\frac{1}{2} 11-2
\end{aligned}
$$




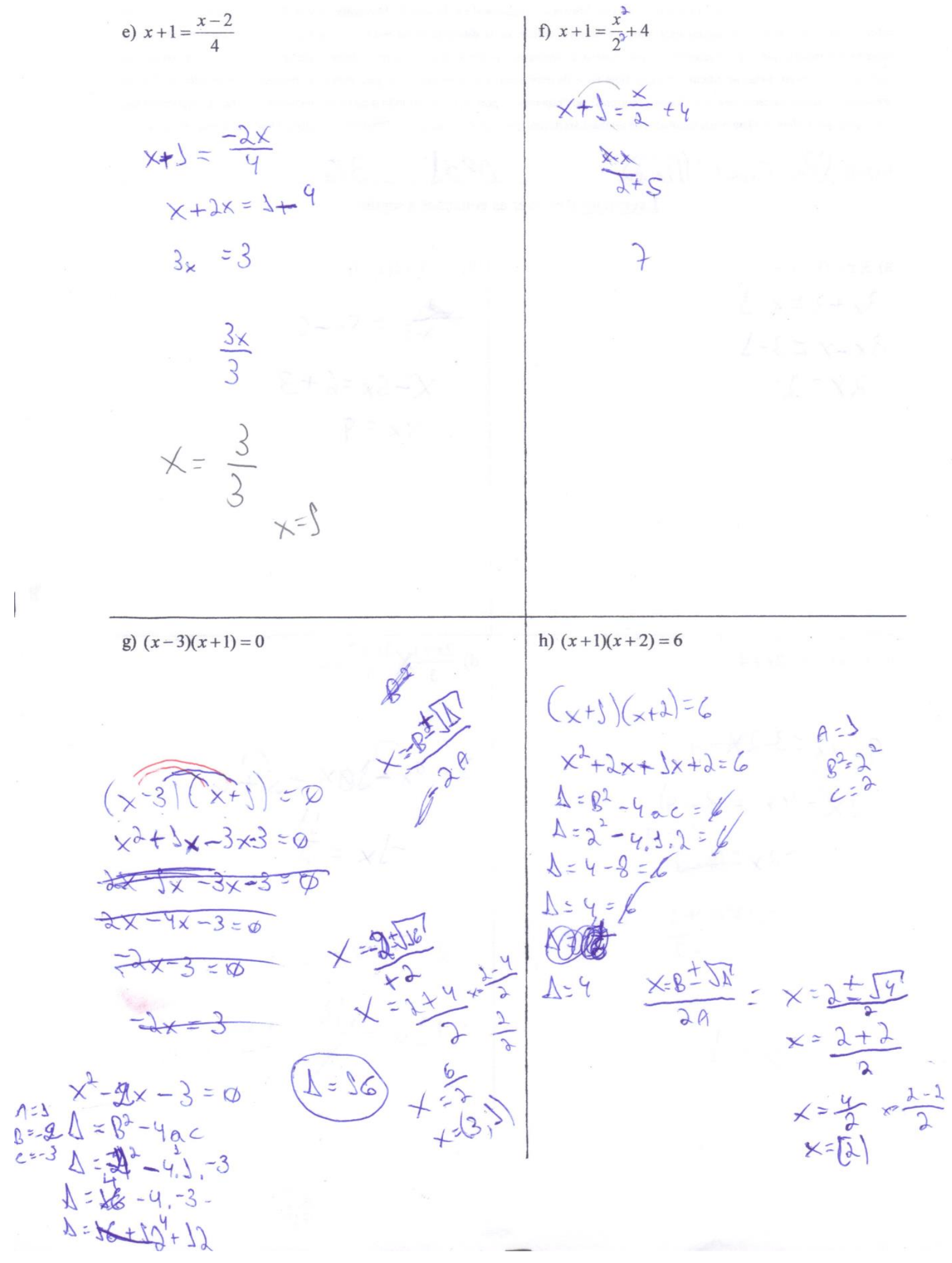


131

Resolução 07

$$
\text { a) } \begin{aligned}
3(x+1)=x-1 \\
3 x+3=x-1 \\
3 x-x=-3-1 \\
2 x=-4 \\
x=\frac{4}{2} \\
x=-2 \\
x=-2
\end{aligned}
$$

c) $9-4 x=3-2 x+4$

$$
\begin{gathered}
9-4 x=3-2 x+4 \\
-4 x=3-2 x+4-9 \\
-4 x+2 x=3+4-9 \\
-2 x=-2 \quad(-1) \\
2 x=2 \\
x=\frac{2}{2} \\
x=1 \\
x=1
\end{gathered}
$$

$$
\begin{aligned}
& \text { b) } x-3=5(x+1) \\
& x-3=5 x+5 \\
& -5 x+x=+5+3 \\
& -4 x=8 \\
& +4 x=-8 \\
& x=\frac{-8}{4} \\
& x=-2 \\
& x=-2 \\
& \text { d) } \frac{2 x+1}{3}-\frac{3 x+2}{5}=2 \\
& \frac{2 x+1}{3}-\frac{3 x+2}{5}=2 \\
& \frac{10 x+5-9 x+6}{15-15}=2 \\
& \frac{1 x+11}{15}=\frac{2}{1} \\
& 1 x+11=30 \\
& x=30-11 \\
& x=19 \\
& x=19
\end{aligned}
$$


132

e) $x+1=\frac{x-2}{4}$

$x+1=\frac{x-2}{4}$

$4 \cdot x+1=x-2$

$4 x+1=x-2$

$3 x+1=-2$

$3 x=-3$

$x=\frac{3}{-3}$

$x=-1$

$x=-1$ f) $x+1=\frac{x}{2}+\frac{4}{1}$

$$
x+1=\frac{x}{2}+4
$$

$2 x+1=x+4$

$$
x+1=4
$$$$
x=3
$$

$$
x=3
$$

1

g) $(x-3)(x+1)=0$

$x^{\prime}=3$

h) $(x+1)(x+2)=6$

$x^{2}+x-3 x-3=0$

$x^{\prime \prime}=-1$

$x^{2}-2 x-3=0$

$x^{2}+2 x+x+2=6$
$x^{2}+3 x+2=6$
$x^{2}+3 x-4=0$

$x^{\prime}=1$

$\Delta=3^{2}-4 \cdot 1 \cdot-4$

$\begin{aligned} \Delta= & b^{2}-4 a c \\ & =2^{2}-4 \cdot 1 \cdot-3\end{aligned}$

$x=x_{-1}^{3}$

$x^{\prime \prime}=-4$

$9+16=25$

\begin{tabular}{l|l}
$4+12$ & $\frac{2+4}{2}=3$
\end{tabular}

$x=\frac{-3 \pm \sqrt{25}}{2 \cdot 1}$

$\left\{\begin{array}{l}\frac{-3+5}{2}=\frac{2}{2}=1 \\ \frac{-3-5}{2}=\frac{-8}{2}\end{array}\right.$

$=-4$

$-$ 


\section{Resolução 08}

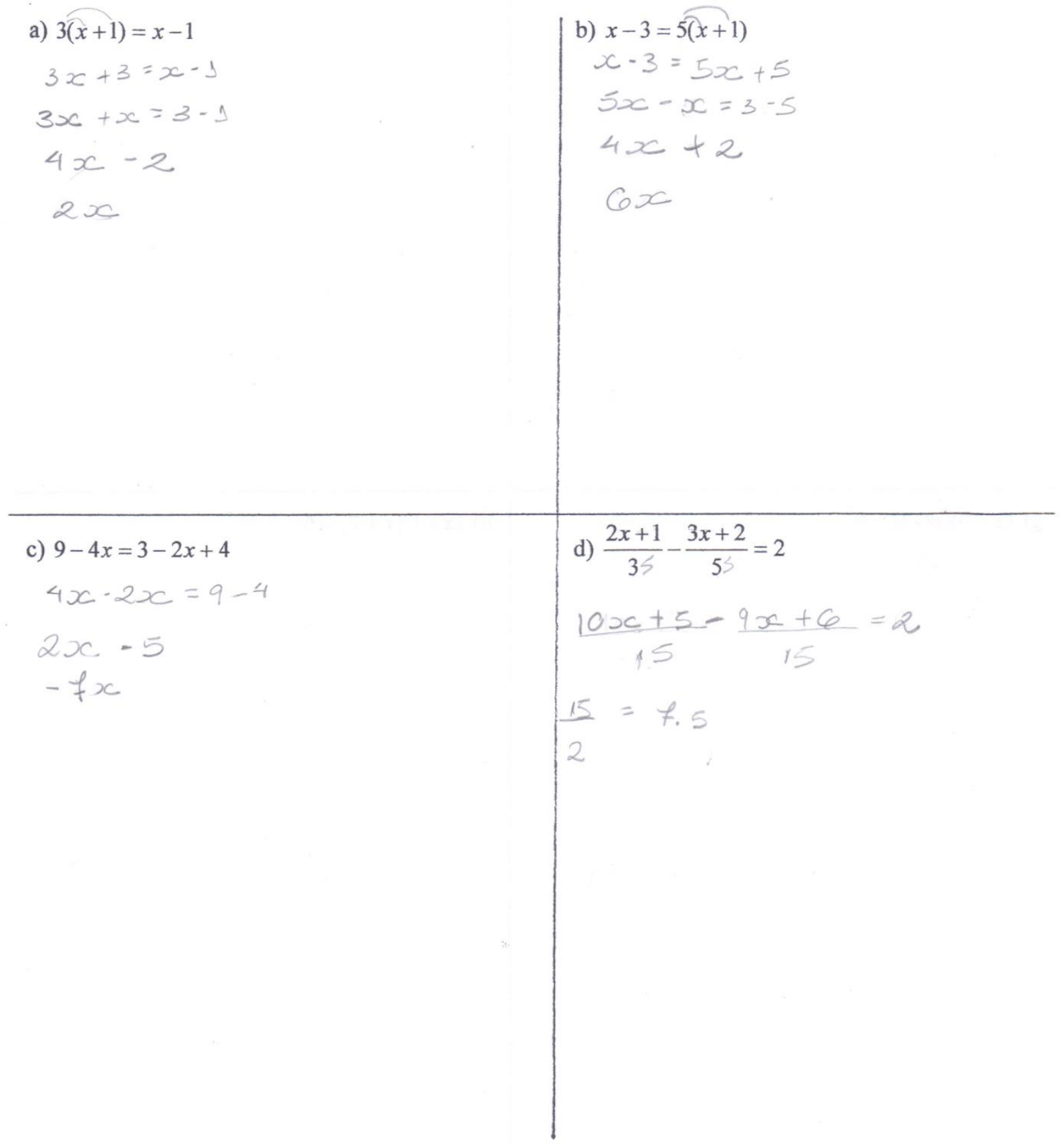




$$
\begin{aligned}
& \text { e) } x+1=\frac{x-2}{4} \\
& 4(x+1)=x-2 \\
& 4 x+4=x-2 \\
& 4 x-x=4-2 \\
& 3 x+6 \\
& 9 x
\end{aligned}
$$$$
\text { f) } x+1=\frac{x}{2}+4
$$$$
2(x+1)=x+4
$$$$
2 x+2=x+4
$$$$
2 x+x=2+4
$$$$
3 x-6
$$$$
3 x
$$

$$
\text { g) }(x-3)(x+1)=0
$$$$
\text { h) }(x+1)(x+2)=6
$$ 


\section{Resolução 09}
a) $3(x+1)=x-1$
b) $x-3=5(x+1)$
$3 x+3=x-1$
$x-3=5 x+5$
$3 x-x=-3-1$
$x-5 x=-3-5$
$2 x=-4$
$x=\frac{-4}{2}$
$x=-2$
$4 x=-8$
$x=\frac{-8}{4}$
$x=-2$
c) $9-4 x=3-2 x+4$
d) $\frac{2 x+1}{3}-\frac{3 x+2}{5}=2$
$4 x+2 x=9-3-4$
$\frac{2 x+1-3 x+2}{15}=2$

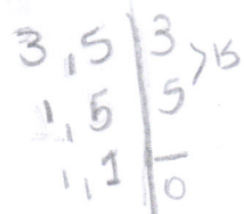
$6 x=-2$
$x=\frac{-2}{6}$
$2 x-3 x=1+2-2$
$x=-0,3$

$$
\begin{aligned}
-1 x & =1 \\
x & =\frac{1}{-1} \\
x & =0
\end{aligned}
$$




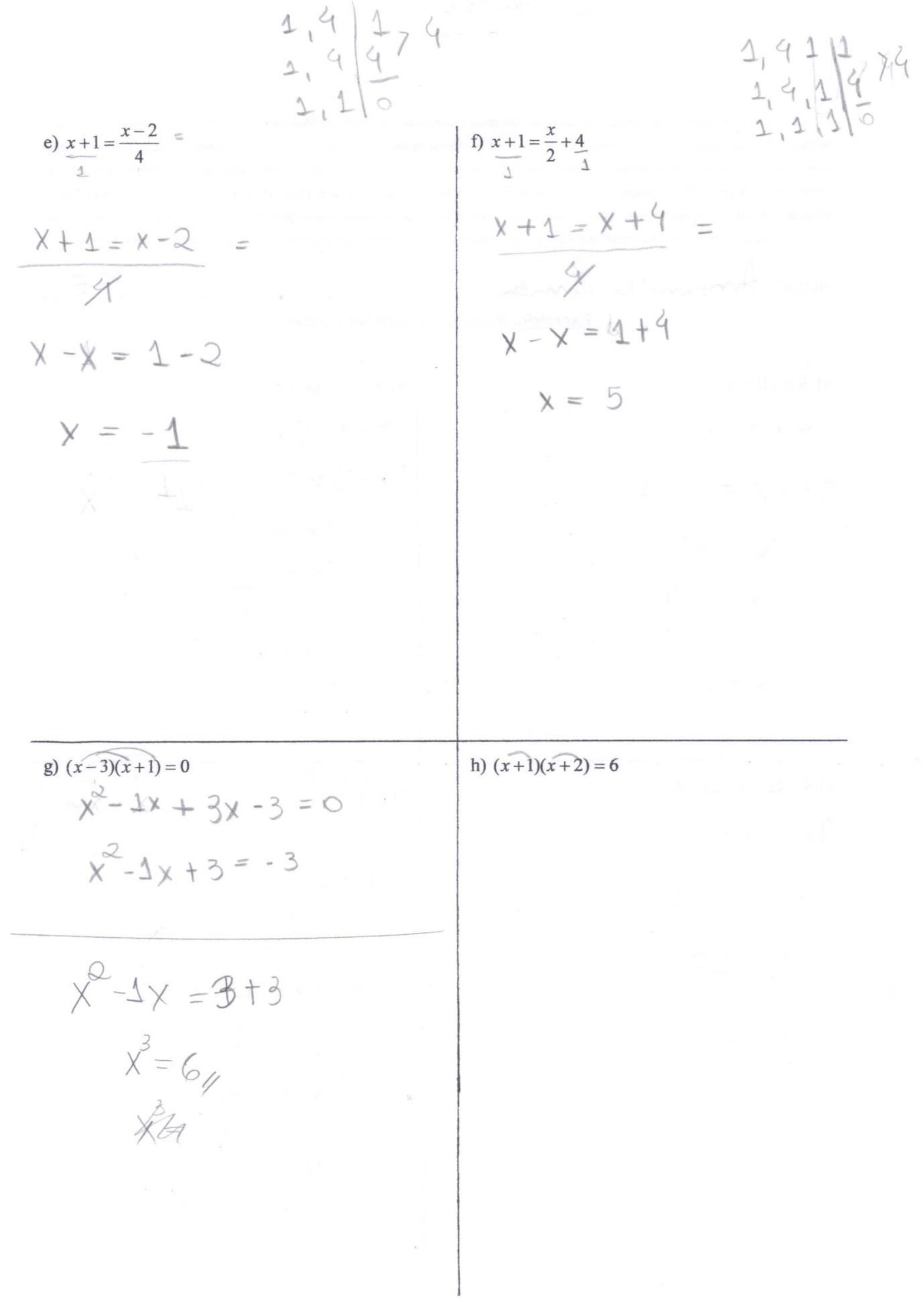


137

Resolução 10

a) $3(x+1)=x-1$

$$
\begin{aligned}
& 3 x+3=x-1 \\
& 3 x+x=3-1 \\
& 4 x-2 \\
& 2 x
\end{aligned}
$$

$$
\begin{aligned}
& \text { b) } x-3=5(x+1) \\
& x-3=5 x+5 \\
& 5 x+5=5
\end{aligned}
$$

c) $9-4 x=3-2 x+4$

$4 x-2 x=9-4$

$2 x-5$

$-7 x$ d) $2 x$

$$
\frac{10 x 5}{15}-\frac{9 x+6}{15}=2
$$$$
15
$$

7.5 
138

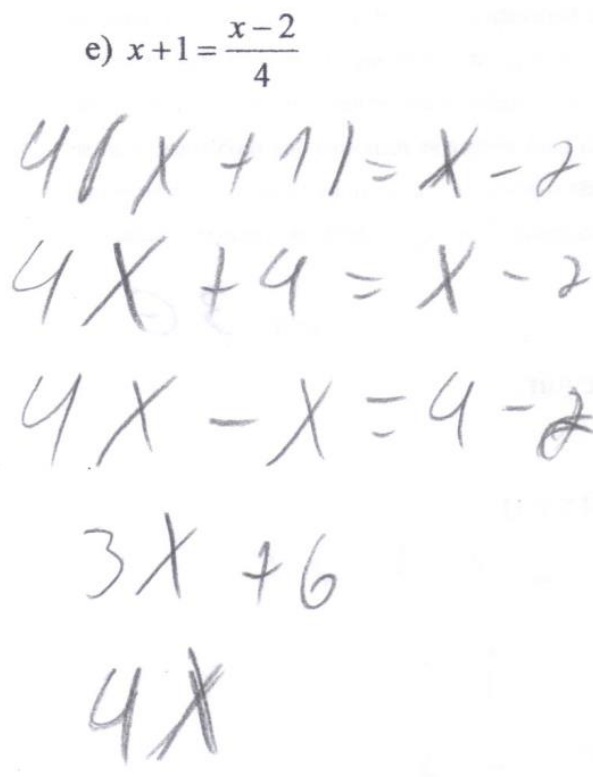

f) $x+1=\frac{x}{2}+4$

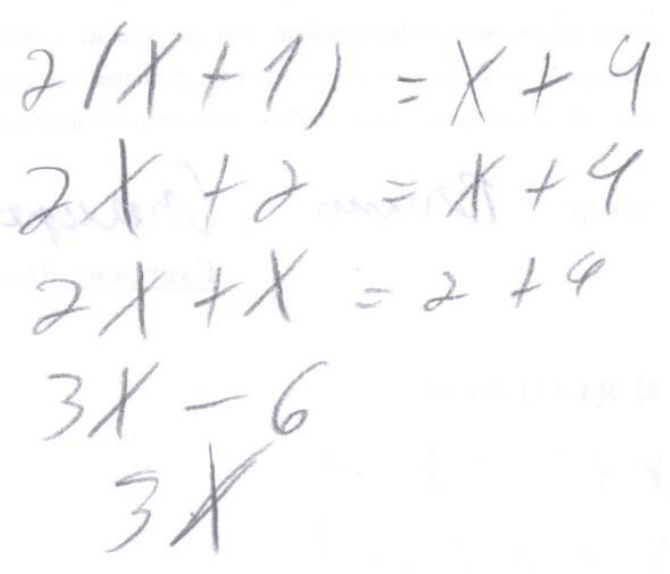

g) $(x-3)(x+1)=0$

h) $(x+1)(x+2)=6$ 
139

Resolução 11

$$
\begin{array}{l|l}
\text { a) } 3(x+1)=x-1 & \text { b) } x-3=\widehat{5(x+1)} \\
3 x+3=x-1 & x-3=5 x+5 \\
3 x-x=-1+3 & 5 x-x=5+3 \\
2 x=2 & 4 x=8 \\
x=1 & x=8 / 4 \\
x=2 & \text { d) } \frac{2 x+1}{3} \frac{3 x+2}{5}=\frac{2}{1} \\
9-3-4=-2 x+4 x & 10 x+5-9 x+6=30 \\
9-7=2 x & 10 x-4 x+11=30 \\
2=2 x & 1 x=19 \\
x=1 & x=19
\end{array}
$$


140

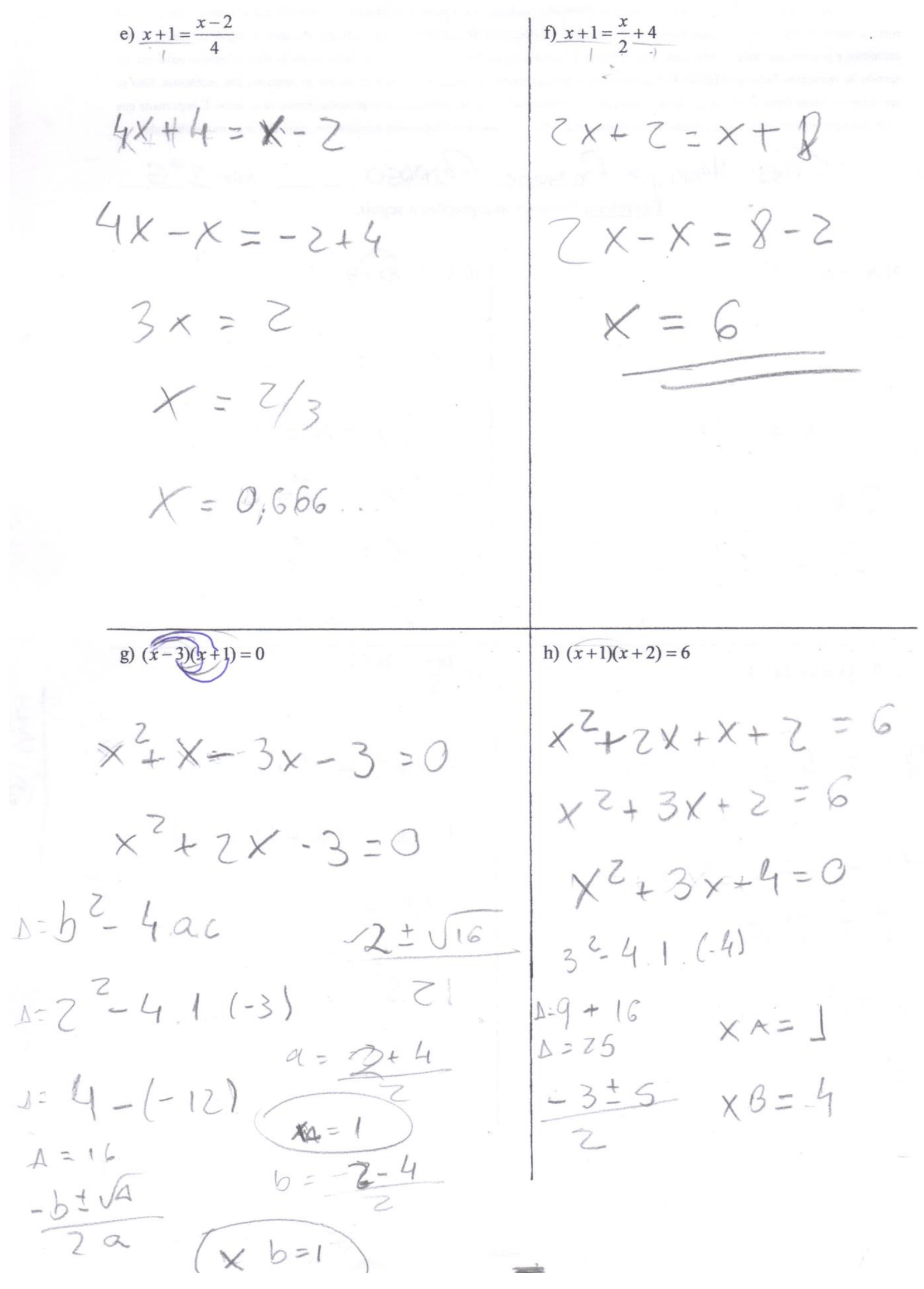


141

Resolução 12

a) $3(x+1)=x-1$

$$
\begin{aligned}
& 3 x+3=x-1 \\
& 3 x-x=-3-1 \\
& 2 x=-4 \\
& x=\frac{2}{-4}=-2
\end{aligned}
$$

b) $x-3=5(x+1)$

$$
\begin{aligned}
1 x & -3=5 x+5 \\
-4 x & =8 \\
x & =\frac{8}{4} \\
& -4 \\
x & =-2
\end{aligned}
$$

c) $9-4 x=3-2 x+4$

$$
\begin{aligned}
& 9-4 x=3-2 x+4 \\
& -4 x+2 x=-9+3+4 \\
& -2 x=-2 \\
& x=\frac{-2}{-2}=+1
\end{aligned}
$$

d) $\frac{2 x+1}{3}-\frac{3 x+2}{5}=2$

$$
\begin{array}{l|l}
3,5 & 3 \\
1,5 & 5 \\
3,1 & 15
\end{array}
$$

$\frac{3 x-5 x}{15}=\frac{-2+2}{18}+2<0$ 
142

e) $x+1=\frac{x-2}{4}$

।

g) $(x-3)(x+1)=0$

$1 x-3+1 x+1=0$

$1 x+1 x=+3-1$

$2 x=2$

$\times \frac{2}{2}=1$

$1 x \times x=2 x$

$1 \cdot 1=1$

$3 \cdot x=3 x$

$3 \cdot 1=3$ f) $x+1=\frac{x}{2}+4$

h) $(x+1)(x+2)=6$

$1 x+1+x+2=6$

$1 x+1 x=-1-2+6$

$2 x=3$

$x=\frac{3}{2}=1,5$ 


\subsection{ENTREVISTAS}

As entrevistas a seguir estão transcritas conforme a conversa entre o entrevistador, chamado de "E", e os alunos, chamados de "A". Sendo assim, trata-se de uma conversa em linguagem coloquial informal, cujo registro procurou-se manter nas transcrições para o texto escrito.

\section{Entrevista 01}

E: Vamo lá então. Me explica, como que você resolveu a primeira questão.
A: A primeira questão?
E: O que a gente tem que fazer pra resolver?

A: Eu multiplico o 3 pelo que tá dentro do parênteses, e depois eu coloquei as letras pra um lado e o número pro outro e cheguei nesse resultado.

E: Tá. O que é que significa o sinal de igual? Você sabe me dizer? Por que é que a equação tem o sinal de igual?

A: Não.

E: Não? Nem ideia? E o que é que acontece quando você passa o número de um lado pro outro?

A: Ele inverte a... Quando ele tá somando ele passa subtraindo, entendeu? Quando tá dividindo ele passa multiplicando.

E: E esse 2 aqui? Por que você passou ele pro outro lado?

A: Porque quando ele passa... Quando ele tá multiplicando... é multiplicando aqui, aqui ele passa dividindo que é a operação inversa.

E: Entendi. Então quando muda de sinal, quando ele passa pro... quando ele muda de lado acontece o quê?

A: A operação fica inversa.

E: A operação é inversa. Certo, aqui é a mesma... a mesma coisa? 
A: Sim.

E: Né? E esse daqui também.

A: Também.

E: E esses primeiros era a mesma coisa. Aí a letra D, por que você tirou o MMC?

A: Eu tentei resolver as questões de cima, e esse aqui eu tive mais dificuldade porque eu não lembrava.

E: Não lembrava e...

A: Eu lembrei quando tava acabando a aula.

E: (Risadas)

A: (Risadas)

E: E o que você lembrou? Só que tinha que tirar o MMC?

A: Sim, e aí como eles são números ímpares, dava pra multiplicá-los, e eu esqueci disso. E dava 15, aí depois era só você fazer... é, multiplicaria em cruz.

E: Mas é porque eles... Porque são números ímpares? E se fosse 3 e 15? Também multiplicaria? São dois números ímpares.

A: É, não sei.

E: Qual seria o MMC de 3 e 15 ?

A: É, não sei. Tem que ver na hora, né?

E: (Risadas)

A: Você me confundiu (risadas).

E: Quando dá pra multiplicar, na realidade, é porque eles são números primos. Você lembra o que são números primos? Só dá pra dividir por ele mesmo e por 1 . Se fosse 3 e 15, você tem que fazer aquele esqueminha que você coloca o 3 vírgula 15 e fatora pra ver qual vai ser o MMC, e o MMC 
seria 15 do mesmo jeito.

A: Tá.

E: E a parte de cima, por que você mudou os números?

A: A parte de cima é porque eu multipliquei em cruz, aí eu fiz 5 vezes $2 x$ e 5 vezes 1 , aí 3 vezes $3 x$ e 3 vezes o 2 .

E: E esse 2 aqui? Ele tá sobre 15, ou não está sobre 15?

A: Não, ele tá fora sobre 15.

E: Tá fora sobre 15? E depois você faria o que com esse 15?

A: Esse 15 eu teria que passar ele multiplicando né, porque ele não tá dividindo?

E: Mas ele multiplica o $x$ ? O $x$ não tá lá do outro lado.

A: Não. Eu teria que multiplicar o $x$, esses $15 x$ vezes aqui, né?

E: Aí $x$ mais 5 ?

A: É, no caso eu tinha errado aqui já (risadas). Mas não daria esse valor.

E: Não daria? Aqui você somou o 10 com o 5 , sendo que o 5 não tinha $x$, né?

A: Isso.

E: Então você já entendeu o seu erro?

A: Sim, errei.

E: E o que mais?

A: Aí esse aqui eu tava fazendo e não deu tempo de terminar.

E: Mas o que você faria? Aqui você fez a distributiva, né?

A: É, no caso agora.. 
E: E aí o igual ficou aqui? Ele estava pra cá e veio para o meio da distributiva?

A: Sim porque eu multipliquei entre eles, né, e deu esse resultado. No caso aqui deu 0 e não coloquei o 0 , né? então tá errado.

E: Então esse resultado aqui da multiplicação ficaria todo do mesmo lado da equação? Continuaria igual a 0 . Depois que você resolve. E por que aqui deu $2 x^{2}$ ?

A: Eu fiz $2 x^{2}$ mais...

E: Mas o que você juntou para dar $2 x^{2}$ ?

A: $2 x^{2} ?$

E: Sim.

A: No caso eu fiz $x$ mais $x$ e coloquei $2 x^{2}$. Mas teria que ser $x^{2}$ mais $x^{2}$. (Risadas).

E: É, exatamente. Que bom que você tá identificando seus erros, é bom quando identifica os próprios erros, quer dizer que a gente sabe o que pode melhorar.

A: É que fazia muito tempo que eu não tinha aula de Matemática disso daqui.

E: Entendi. Agora você já tá mais... com as coisas mais frescas na cabeça.

A: Eu tive tipo, na sétima série aula de Matemática disso daí.

E: Oitava série, primeiro colegial você também teve aula de Matemática também.

A: Foi bem pouco.

E: Mas teve alguma coisa, equação você resolvia.

A: Mas disso aqui não.

E: E esses três aqui, por que você deixou em branco?

A: Esse aqui eu não sabia fazer. Esse aqui eu sabia fazer mais ou menos, mas não deu tempo. Mas esse aqui eu não sabia fazer. 
E: Esse aqui não é parecido com aquele outro que tinha fração?

A: Sim, mas no caso esse aqui eu tive mais dificuldade. Não sabia fazer não.

E: Você tem alguma ideia de como que faria esse?

A: Não, esse não.

E: Nenhuma? Se eu tirar o MMC desse daqui?

A: Daria 2?

E: Qual é o denominador do $x+1$ ?

A: 1 .

E: 1, então você tira o MMC de 1 e 4. E qual seria o MMC de 1 e 4 ?

A: 1 e 4 dividido por 4 seria 2, então ficaria 2 vezes 1 vai dá 2 . E aqui eu conseguiria multiplicar pelo $x$ ou teria que copiar ele primeiro?

E: Então, você tem que mudar a parte de cima, lembra? No outro você mudou a parte de cima também?

A: Mas e o igual? Deixa do jeito que tá?

E: Então, você tá colocando todo mundo sobre 2.

A: Certo.

E: É isso? Então, por que é que a gente tira o MMC? Pra gente poder comparar duas frações, a parte de baixo tem que ser igual. Então aqui é sobre 4 e aqui é sobre 1, e você vai colocar todo mundo sobre 2 .

A: E eu multiplico em cruz também.

E: Pode ser. É um jeito de resolver.

A: Aí fica $4 x+4=x-2$. É... $4 x$, o $x$ tá mais então aqui vem menos, $4 x-x$ igual a $4-2$, por 2 . 
E: O que é que você faz com esse 2 ?

A: Pera, to em dúvida! Porque ficaria $3 x=-6$. E esse 2 aqui, eu faria o quê?

E: Esse 2, como ele tá dos dois lados da equação, você pode cortar. Então ele some. Esse 2 aqui não some, some só o de baixo.

A: Ah, então ficaria $3 x=-6$. Aí eu teria que multiplicar?

E: Eu tenho que achar o valor do $x$, o que eu teria que fazer?

A: Dividir o 6 por 3 ?

E: Sim.

A: Então seria -2 .

E: Isso. Certo?

A: Não é difícil.

E: Não é difícil? Já deu pra lembrar?

A: Já. Daí nesse aqui é a mesma coisa. Ficaria $2 x+2=x+4$.

E: Esse 4 aqui tá sobre quanto?

A: Tá sobre... nada, tá sozinho.

E: Tá sobre 1, né? Então pra você transformar ele em alguma coisa sobre 2, ele tem que multiplicar por 2 porque a fração... se você escrever 4 sobre 2 não representa 4 , você teria que escrever 8 sobre 2 pra poder representar o 4 .

A: 8.

E: Certo? Aí corta o 2 de baixo que nem a gente fez no anterior.

A: Então vai ficar $2 x-x=-2+8$, então o $x=6$.

E: Muito bem, é isso aí. Posso te dar um exemplo pra ver como você faria? 
A: Pode.

E: Se você tivesse isso, como você resolveria? $-5 x=10$.

A: $-5 x=10 ?$ Não sei.

E: Quero saber o valor do $x$. É bem parecido com isso, não é? Aqui era $3 x=-6$.

A: $x=10$ sobre $-5, x$ daria -2 .

E: Isso, certinho. Só queria ver se você ia trocar o sinal quando passa pra lá, mas você falou certinho no começo: quando muda de lado, inverte a operação. Muito bem. É isso então.

\section{Entrevista 02}

E: Então vamo lá. Me explica como que você resolveu a primeira equação.

A: Eu distribui o 3 pelo que tá entre parênteses e depois resolvi... eu esqueci como falar agora, né? Aí ficou $3 x+3$, porque eu fiz o 3 vezes 1, aí eu copiei essa parte. Aí aqui eu inverti os lados, passei o $x$ pra cá e ficou $3 x-x+3$. Ficou $2 x+3$ porque passei o $x$ pro outro lado e o 3 pro outro lado e resolvi.

E: Tá. E essa aqui? Mesma coisa?

A: Sim.

E: E aqui essa parte aqui, quando você passou ficou $2 x=-4$.

A: $\operatorname{Sim}, 2 x=-4$.

E: Por que quando você passa pra cá o 3, por exemplo, ele vira -3 e quando você passa o 2 pra lá, ele não vira -2 ?

A: Não, sim. Na verdade eu não tinha reparado nisso mesmo. É que geralmente a gente não fixa nisso mesmo.

E: Então, mas o que acontece quando você vai passar um número pro outro lado? 
A: Troca o sinal.

E: Troca o sinal sempre?

A: Ele passa multiplicando ai tu passa pro outro lado dividindo.

E: Passa dividindo. Então na realidade o que ele troca é a operação.

A: A operação e o sinal.

E: Certo? Então por exemplo, esse $x$ aqui que você passou pro outro lado ele tava subtraindo...não, tava somando aqui e passou subtraindo. O 3 que tava somando, passou pra lá subtraindo. Aí esse 2 que tava multiplicando, você passou pra lá dividindo. Aqui tá certinho. E esse -4 aqui? Ficou $-4 x=8$, você passou o 4 pra lá trocando o sinal.

A: Sim.

E: O que você acha? Que tem que trocar o sinal sempre?

A: Creio que sim. Quando passa de um lado pro o outro.

E: Mas aí inverte o sinal e a operação?

A: É.

E: É? Nesse caso aqui também?

A: É.

E: Tá. Então vou te contar que só a operação que inverte. O sinal não inverte. Dá a impressão de que inverte o sinal porque quando tá somando a gente passa pro outro lado subtraindo, e aí o mais acaba virando menos, mas o que a gente tá trocando é a operação. E aqui, quando tá multiplicando, a gente passa dividindo, mas eu vou dividir pelo mesmo número, sem trocar o sinal. Só que na realidade esse você deveria ter dividido por -4 . Tá, a mesma coisa que você fez aqui.

A: Mas como assim? Eu não entendi.

E: Esse -4 tá multiplicando o $x$, então você vai passar pro outro lado dividindo por -4 , porque 
na realidade o que a gente tá fazendo aqui...

A: O sinal mantém?

E: O sinal mantém. O que é uma equação? Você sabe me dizer?

A: Não, não sei.

E: São duas coisas que são iguais, certo? É uma igualdade. Então esse sinal de igual aqui tá dizendo que a conta que eu fizer do lado esquerdo, vai dar a mesma conta do lado direito. Certo? Então quando eu chego nessa igualdade aqui, o que a gente faz é a mesma conta dos dois lados. Imagina uma equação como se fosse uma balança, então ela tá equilibrada. Se você somar 3 de lado, ela vai desequilibrar. Então você tem que somar 3 do outro. Então aqui, na realidade, se somar 3 e subtrair 3, eu tenho que tirar 3 desse lado e vou ter que tirar 3 do outro. Quando eu divido por -4 aqui, o que você fez foi: você dividiu por -4 de um lado e aqui virou $x$ só, e aqui dividiu por 4 do outro, então você não fez a mesma coisa dos dois lados, você não manteve a igualdade.

\section{A: Ok.}

E: Entendeu? Então quando a gente troca um número de lado, na realidade o que a gente troca, o que a gente inverte é a operação, tá? Aqui você fez a mesma coisa, você chegou no $-2 x=-2$ e aqui você dividiu por -2 e aí depois aqui você dividiu por 2 positivo. Você fez uma coisa de um lado e outra coisa do outro. Aí não mantém a igualdade. Tá?

\section{A: Entendi.}

E: E esse da fração?

\section{A: Esse aí eu me perdi todo.}

E: Se perdeu todo? Por que você tirou o MMC?

A: Porque eu me lembrei que era pra tirar o MMC. Aí eu tirei o MMC. Esse aqui eu não me lembro muito bem como que eu fiz porque fazia tempo que eu não fazia conta de fração, entendeu? 
E: Então, pra gente comparar duas frações elas têm que ter o mesmo denominador. Só que uma tem o denominador 3 e a outra tem o denominador 5, então não dá pra gente comparar. Então você tira o MMC pra ficar tudo com o mesmo denominador. E por que você mudou o de cima?

\section{A: Como assim?}

E: Porque aqui era $2 x$ e virou $10 x$.

A: Porque falaram pra multiplicar em cruz.

E: Falaram? (Risadas)

A: Eu não lembrava disso aí também.

E: Não lembrava? Na realidade o que a gente faz é esse número aqui...

A: Multiplica pelo de baixo e multiplica pelo de cima.

E: Isso, já lembrou. Então esse 3, pra virar 15, você multiplicou por 5, então a parte de cima toda você tem que multiplicar por 5 também. Aqui esse 5 , pra virar 15, você multiplicou por 3, então a parte de cima toda você tem que multiplicar por 3. E o 2? Por que você não fez nada com o 2?

A: Não, porque tinha acabado a aula.

E: Tinha acabado? Quer continuar agora? Como você continuaria?

A: Eu já nem lembro, esqueci.

E: Você prefere começar de novo? Ou quer continuar daí?

A: Não, dá pra ir. É que eu não tô conseguindo diferenciar os sinais. É +6 né?

E: É +6 .

A: $+5+6+11$.

E: Por que você tinha circulado esse sinal de menos aqui?

A: Coloquei ele entre parênteses pra mim, porque acho mais fácil de diferenciar na hora de continuar a equação. 
E: Então, mas aqui você circulou o sinal de menos.

A: Não, isso é porque eu estava explicando pra um colega meu.

E: Entendi. Mas esse sinal de menos aqui, é um sinal da fração toda, não é?

A: Isso porque ele tá aqui. Como ele ficou junto com o 9 positivo coloquei o 9 entre parênteses pra poder diferenciar.

E: Mas por que só o 9 e o 6 não?

A: É porque é o 9 que tá em contato, vamos dizer assim, com o sinal positivo.

E: Mas então, esse menos não é da fração toda?

A: É.

E: E o $3 x$ e o 2 tavam na fração?

A: Tá certo. Então o 6 ficaria negativo também.

E: O 6 ficaria negativo também. Certo?

A: Então seria $+5-6 x-6$ que daria -1 .

E: Isso, muito bem.

A: Tem coisas que eu lembro ainda. É falta de atenção mesmo.

E: E agora?

A: Agora eu já não saberia mais o que fazer. (Risadas)

E: Esse 15 aí, dá pra tirar ele daí e passar pro outro lado?

A: Como ele tá dividindo, ele passaria multiplicando.

E: Sim.

A: Aí ficaria $1 x-1=2 \cdot 15$, então, $1 x-1=30$. Aí esse 1 vai pra cá, e ficaria $1 x$, mas esse 1 não seria necessário, seria só $x$ mesmo. Fica $x=30$, como ele passa...então não seria nesse caso que 
ele trocaria de operação, né, ele passa pro outro lado positivo.

E: Isso. Qual é a operação inversa da subtração? É a soma.

A: Sim.

E: Então você vai passar ele pro outro lado somando e o $x$ é 31. Certo?

A: Sim, $x=31$.

E: Muito bem. Deu pra lembrar melhor hoje?

A: Tô lembrando.

E: E essa parte de trás não deu tempo ou você não lembrava nada?

A: Não deu, eu cheguei tarde na aula.

E: Tenta fazer um. O que você faz com esse 4 aí?

A: Tô pensando aqui. Ele está dividindo, então posso passar pro outro lado multiplicando.

E: Pode.

A: Então ficaria $x+1 \cdot 4=x-2$, aí a gente resolveria o caso da fração.

E: Isso.

A: Aí ficaria $x \ldots$

E: Quem tá vezes 4? Só o 1? Quando você passa o 4 pro outro lado multiplicando, ele vai multiplicar quem?

A: Ele vai multiplicar o 1.

E: Só o 1? E se você escrevesse ao contrário e colocasse o 4 na frente, também multiplicaria o $x$ ?

A: É, os dois deveriam estar entre parênteses.

E: Isso. Ele tem que multiplicar todo mundo, então o $x+1$ tem que estar entre parênteses. 
A: Tá certo. Aí ficaria $4 x+4=x-2$, aí depois $4 x-x=-2-4$, então $3 x=-6, x$ igual a -6 dividido por 3 .

E: 3 positivo ou negativo?

A: Esse 3 é positivo.

E: Por quê?

A: Por causa que só muda a operação.

E: Isso, muito bem.

A: Então $x$ seria igual à 6 dividido por 3 . Tô meio ruim de Matemática, mas seria 2 .

E: Certo, mas seria positivo ou negativo o 2 ?

A: O 2 é negativo.

E: Isso, certo?

A: Certo.

E: E esse? Parecido também.

A: É.

E: Depois desse você tira de letra.

A: A professora tá passando um trabalho lá pra quem não fez o trabalho da semana passada.

E: E você já fez?

A: Já e entreguei. Tive que fazer em dupla por causa do meu colega que tá com o braço quebrado.

E: Entendi. Nesse caso aqui, qual que é a diferença desse pra esse? Você vê alguma diferença?

A: Esse aqui tem um 4 no fim.

E: É, e esse 4 tá sobre 2? 
A: Não.

E: Não, ele não tá sobre 2, mas aqui olha, o que você fez: você tá multiplicando os dois lados da equação por 2. Quando você multiplica isso por 2 , vai virar $(x+1) \cdot 2$, mas quando você multiplica o $\frac{x}{2}$ por 2 , ele vira só $x$, e o 4 vai ser multiplicado por 2 também. Aí você tem que tirar o MMC.

A: Que seria 2.

E: Sim, então coloca aí: todo mundo sobre 2 .

A: Aí divide pelo de baixo e multiplica pelo de cima.

E: Agora tá todo mundo sobre 2, igual à esse.

A: Tá certo.

E: Muito bom, é isso aí. Muito obrigada.

\section{Entrevista 03}

E: Então vamos lá, me explica o que você fez aqui na letra B.

A: Aí? Então, aí eu deixei esse aqui igual, o $x-3$ igual, aí eu multipliquei o 5 pelo $x$ e o 5 pelo 1 aqui, aí ficou $5 x+5$. Aí eu deixei... aí eu inverti, aí eu coloquei as letras pra um lado e os números pro outro. Aí ficou $x$, aí como aqui era $+5 x$, virou $-5 x$.

E: Por quê? Quando muda de lado a gente faz o quê?

A: Quando a gente muda de lado a gente inverte o sinal.

E: Inverte o sinal?

A: É, o que era mais ficou menos. Aí eu mantive o 5, que era +5 , eu mantive, e o 3 que ele tava do lado de lá, eu trouxe ele pro lado de cá, e como era menos, ficou mais. 
E: Certo.

A: Aí eu fiz $x-5 x$, deu $4 x$. Não? É, não. Eita, acho que eu confundi aqui, deu $4 x$.

E: E era pra dar quanto?

A: Era pra dar $-4 x$.

E: Tá, então vamos supor que você lembrou e ficou $-4 x$. E aí? Como você continuaria?

A: Aí ficou $-4 x=8$. Aí aqui...

E: Quando você for passar esse 4 pro lado de lá, ele tava multiplicando e você passou ele dividindo.

A: Passei.

E: Agora que ele é $-4 x$, o que é que isso mudaria?

A: Isso mudaria porque aqui ficaria mais com menos e ficaria -2 .

E: Isso, certo?

A: Certinho.

E: Que bom que você mesmo identificou seu erro. E quando passa multiplicando ele não inverte o sinal? Você falou que quando muda de lado troca o sinal.

A: É, troca o sinal, mas só que aqui ele já tá...

E: Então, era -4 e passou -4 dividindo. Por quê?

A: Agora você me pegou.

E: Na realidade quando muda de lado inverte a operação. Então aqui, por exemplo, você passou esse 3 pra lá e ele tava subtraindo e passou pra lá somando, então parece que ele mudou de sinal, mas na realidade inverteu a operação. Aqui ele tava multiplicando e vai passar pra lá dividindo, então o sinal não vai mudar nada, continua a mesma coisa. Tá?

A: Sim. 
E: Nesses daqui da letra $\mathrm{D}$, por que você tirou o MMC?

A: Eu tirei o MMC por causa que aqui tinha o.. qual é o nome?

E: Denominador.

A: O denominador 3, o denominador 5 e o denominador 1, aí eu tive que tirar o MMC pra saber um denominador para todos e foi o 15 .

E: Por que é que eles têm que ter o mesmo denominador?

A: Por causa que não vai dar pra fazer a conta se tiver assim. Ou dá e eu não sei.

E: Não, não dá. Pra gente poder fazer conta com fração, pra comparar frações, elas têm que ter o mesmo denominador sempre. Por isso a gente tira o MMC. E aqui olha, daqui pra cá, esse -3 aqui, o menos é do -3 , quando você faz o -3 vezes $3 x$ vai dar $-9 x$. E -3 vezes 2 ?

A: -3 vezes 2 ? Vai dar -6 .

E: Vai dar -6. Esse menos aqui era da fração toda, como você multiplicou a fração toda por 3, esse menos é o sinal do 3. Aí fica -3 , e aí ou você multiplica aqui e fica $9 x+6$, só que depois você vai fazer o menos pra todo mundo, então o menos vai virar $-9 x$ e -6 também.

\section{A: Entendi.}

E: Não vou te roubar muito porque já bateu o sinal, obrigada.

\section{Entrevista 04}

E: Vamo lá, me explica o que é que você fez na letra A?

A: Eu meio que acho que lembrei, né?

E: Sem problemas. Eu quero só entender o que foi que você pensou.

A: Eu pensei que eu tinha que fazer a conta aqui, né? Fazer vezes, vezes.

E: Certo. 
A: Aí eu deixava aqui normal. Aí depois eu passava todos os $x$ antes do igual, aí mudava o sinal, sempre muda o sinal.

E: Quando muda de lado muda o sinal?

A: "Aham". E os não $x$ ficava pro...

E: Pro outro lado?

A: Aí vai mudar o sinal também, desse lado aqui.

E: "Aham".

A: Aí eu fiz 3-1, porque o $x$ sozinho vale 1 .

E: "Aham".

A: Aí deu $2 x$. E fiz... porque mais com mais dá... menos com menos dá mais. Eu fiz $3+1$ que deu -4 .

E: Mas se dá mais, por que deu -4 ?

A: É porque se eu tô devendo 3 e tô devendo 1 vai ficar... tô devendo -4 .

E: Entendi. E aí?

A: Aí depois eu fiz -4 dividido por 2.

E: Aqui quando você passou esse 2 ele tava multiplicando, passou pro lado de lá dividindo e trocou o sinal?

A: Trocou.

E: Então toda vez que muda de lado troca o sinal?

A: É.

E: Mesmo quando tá multiplicando e dividindo?

A: Isso. 
E: E aqui você não fez isso, olha, esse aqui, como é bem parecido e aqui era $-4 x$ e você passou o - 4 dividindo sem trocar o sinal dele. Qual dos dois você acha que tá certo?

A: Esse.

E: Esse aqui?

A: É.

E: Então toda vez que troca o sinal... toda vez que troca de lado, muda o sinal?

A: Isso.

E: Eu vou te contar que é esse que tá certo. Toda vez que muda de lado a gente inverte a operação, não o sinal. Então por exemplo esse + 3 que você trocou de lado, ele tava somando, quando você passou pro outro lado ele vai subtrair, por isso que parece que ele trocou de sinal, mas o inverso da operação da soma é a subtração. Nesse caso aqui, o 2 que tava multiplicando, ele vai passar pro outro lado dividindo e não troca o sinal, continua dividindo por 2 .

A: Eu entendi.

E: Tá? Aí aqui de novo você fez, - 2 sem inverter o sinal, aí ficou certinho. Parece que você trocou o sinal então não é sempre que o número muda de lado que troca o sinal, sempre que ele muda de lado você inverte a operação. Tá? E esse da letra D, que era diferente?

A: Eu vi e eu não sei fazer essa porque achei mais complicado. Esse o primeiro... é que eu não sei falar.

E: Você tirou o MMC, e aí deu 15.

A: Deu 15, eu fiz... é 15... 3 vezes 1 , não... o que é isso que eu fiz? (Risadas)

E: (Risadas)

A: Peraí... eu não lembro o que eu fiz aqui.

E: Não lembra? Por que é que deu $10 x+5$ ?

A: Não. 
E: Como você faria se fosse resolver agora? Quer tentar? Esquece aqui, deixa aqui e resolve embaixo. Como você faria?

A: Eu faria esse dois aqui, o $x$ primeiro, mas eu acho que não tá certo.

E: Pra você poder juntar duas frações, elas têm que ter o mesmo denominador. Então você tem que tirar o mesmo MMC, que nem você fez aqui, certinho. Como você mudou o número de baixo, você tem que mudar o de cima também. Então aqui, se você mudou de 3 pra 15, quer dizer que você multiplicou por 5, então a parte de cima também tem que multiplicar por 5.

A: Foi isso, eu fiz 5 vezes o 2, que deu $10 x, 5$ vezes o 1 que deu 5. Aqui foi por 3, 3 vezes 3 deu 9 e 3 vezes 2 deu 6 .

E: Isso. E o que é que aconteceu pra próxima linha?

A: Eu fiz $x \ldots$ deixa eu ver... aqui deu é, 10 vezes o $5 \ldots$ não. O 10 com 5 que deu 15 e o 9 mais o 6 que deu 15 também, aí eu coloquei o 15 aqui dividindo por 2 porque vai dar 15 os dois.

E: Tá, e aí por que dividido por 2? Esse 2 tá multiplicando?

A: Porque... não, agora você me pegou.

E: Agora tô te confundindo? (Risadas)

A: Eu acho que esse aqui passa multiplicando... não, dividindo.

E: Não lembra?

A: Não.

E: Você juntou o $10 x+5$ deu $15 x$ e o $9 x+6$ deu $15 x$ também. Só que o problema é que você só pode juntar $x$ com $x$ e número sem $x$, com número sem $x$. Se juntar o $10 x$ com $9 x$ e o 5 com o 6. E aí continua a equação. Tá?

A: Entendi agora.

E: Vamos ver a parte de trás. E nesse daqui, o que é que você fez? Você passou o 4 pra lá, ele tava dividindo né? 
A: Isso.

E: E aí? Me conta.

A: Foi que nem... eu só passei o 4 pra cá pra mim fazer 4 vezes o $x$, que nem nas primeiras.

E: Ele passou multiplicando por quê?

A: Porque ele tava dividindo.

E: Isso. Você vai passar multiplicando o 4 ou o -4 ?

A: O menos porque mudou de lado.

E: Então, a gente acabou de falar sobre isso. Quando muda de lado troca o quê? A operação. Então tá multiplicando e vai passar... tá dividindo e vai passar multiplicando e vai continuar sendo 4. Então aqui era pra multiplicar por 4 só.

A: "Aham".

E: Tá? Nesse daqui a mesma coisa, tava dividindo por 2, só que o problema nesse daqui, é que esse 4 não tava dividido por 2, então não dá pra você fazer que nem no de cá. Antes, você teria que deixar todo mundo sobre 2, e aí quando todo mundo estiver sobre 2, você passa pro outro lado. O que é que é uma equação? Você sabe me dizer? Ela tem esse sinal de igual, por quê? Não faz ideia? Então ela tem esse sinal de igual porque são duas coisas que são iguais, se a gente calcular as duas vai dar a mesma coisa. Então pensa numa equação como se ela fosse uma balança, tudo que você faz de um lado, você tem que fazer do outro pra ela manter o equilíbrio, manter a igualdade. Então por exemplo, nesse caso aqui, tava dividido por 4, pra tirar esse 4, tenho que multiplicar por 4. Então se eu vou estar multiplicando o lado direito por 4, eu tenho que multiplicar o lado esquerdo por 4 também. Se eu multiplico um lado só, a balança fica desnivelada. Aí nesse caso aqui não é todo mundo que tá sobre 2, então, pra eu multiplicar por 2, eu tenho que multiplicar todo mundo. Então esse lado todo aqui vai ficar vezes 2, inclusive o 4, eu teria que fazer 2 vezes 4 que vai dar 8 .

A: Entendi.

E: E nesse daqui da letra G? 
A: Esse aqui eu fiz os dois nos parênteses vezes o $x$ e fiz vezes 1 , depois 3 vezes $x$ e 3 vezes 1 . $\mathrm{E}: \mathrm{E} x$ vezes $x$ dá quanto?

A: Dá... $x$.

E: Dá $x$ ?

A: É porque 1 vezes 1 dá 1.

E: E 2? 2 vezes 2 dá 2?

A: Não. Dá 4.

E: É, 4. E 3 ? 3 vezes 3 não é 3 também.

A: É 9.

E: Então $x$ vezes $x$ não é $x$. Você pegou o exemplo do 1 só, mas não vale pra todos os números.

A: É $x^{2} ?$

$\mathrm{E}: \mathrm{E} x^{2}$.

A: Eu tinha feito isso aqui. (Risadas)

E: É, você fez, mas apagou. Certo? Então $x$ vezes $x \ldots$ todo número vezes ele mesmo é ele ao quadrado.

A: "Aham".

E: Tá bom?

A: Tá bom, eu entendi. É que nem aqui também.

E: Que nem aí, é a mesma coisa. Certo?

A: Certo. 
E: Acho que é isso, obrigada.

A: De nada.

\section{Entrevista 05}

E: Vamo lá então. Me conta o que é que você fez aqui na letra A.

A: Aqui é... tipo eu não falo direito o nome.

E: Não tem problema.

A: Multipliquei o número de fora pelo de dentro do parênteses.

E: "Aham".

A: Aí eu fui, isolei o $x$ e daí eu já descobri o resultado do $x$. E aqui a mesma coisa.

E: Quando você isola o $x$, aí você tem que passar o $3 \ldots$ o que não é $x$ pra um lado e o que tem $x$ pro outro. Por que quando você mudou o 3 aqui ele virou -3 ?

A: Porque sempre quando tá positivo... quando muda pro outro lado do igual, muda o sinal.

E: Muda o sinal sempre que troca de lado?

A: É.

E: Mas e esse 2 aqui? Olha, era $2 x=-4$. Você passou o 2 pro outro lado e ele não trocou de sinal. Por quê?

A: Não, na verdade eu que tinha colocado aqui, daí eu tinha multiplicado por -1 , né, daí vai ficar os dois positivo. Daí depois eu... é eu esqueci de colocar o menos aqui.

E: Entendi. E aqui quando você multiplicou por $-1, \mathrm{o}-2$ ficou positivo e o $x$ continua igual? Porque quando você multiplica por -1 , você multiplicou só um lado? Porque o que acontece... na equação são duas coisas iguais, certo? É como se ela fosse uma balança. Se você multiplica um lado por -1 , o outro também tem que multiplicar por -1 . 
A: É.

E: Nesse caso então, o começo é parecido, né?

A: É.

E: E o $-4 x$, você passou ele pra lá.

A: Positivo.

E: Positivo porque ele trocou de lado.

A: É.

E: Aí ele muda de sinal e troca de operação? Ele tava multiplicando e passa dividindo.

A: Daí aqui como que tava negativo ficou -1 , daí eu fiz certo. Aí ficou o -2 .

E: Isso. Aí você multiplicou os dois por -1 . Mas aqui não era $x$ negativo e aqui virou negativo. Por quê?

A: É porque a gente tinha feito que o sinal do negativo... daí tipo, tinha ficado tipo com o $x$ e o 4 tinha passado, entendeu?

E: Entendi. Então aqui tinha que ter um sinal de menos também?

A: É.

E: Tá, tá bom. E nesse aqui você passou o -2 pro lado de lá dividindo e ele... isso aqui é um +2 ou $-2 ?$

A: -2 .

E: -2 ? E aí -2 dividido por -2 deu -1 ?

A: É. Daí um multipliquei por -1 e deu 1.

E: Certeza que dá -1 ? Se você for dividir -2 por -2 .

A: Daí fica positivo. 
E: Fica positivo, isso. Então olha, vou te contar um segredo. Quando muda de lado, não troca o sinal, o que troca é a operação. Então quando você divide aqui, por exemplo, você tá multiplicando por -4 você vai dividir por -4 . Não vai inverter o sinal. O que dá a impressão de que troca o sinal, por exemplo, é que aqui era +3 , então eu tô somando, a operação inversa da soma é a subtração, então vai passar pra lá como -3 .

A: Entendi.

E: E Aí parece que trocou de sinal. Tá?

A: Entendi.

E: Na letra D, me explica.

A: Tive dificuldade.

E: Mas você lembra o que você fez, mais ou menos? Por que ficou todo mundo sobre 15 ?

A: Porque... aí você multiplica o de cima pelo de baixo, né? Aí você coloca aqui, aí depois a gente cortou o 15. Daí ficou a...

E: Multiplica o de cima pelo de baixo? Como assim?

A: É. Tipo, a gente fez assim, daí... nem lembro direito como a gente fez.

E: Como você chegou nesse 5 e esse 3 do parênteses?

A: Calma, fez 3 vezes 5, daí ficou 15.

E: "Aham".

A: Daí ficou 15, 15 aqui, né, pra deixar igual e aí cortou. Aí ficou a conta aqui e a gente isolou o $x$ do mesmo jeito.

E: Como que chegamos nessa parte de cima? Como que o 2 virou 30, por exemplo?

A: Cara, eu não lembro. É uma boa pergunta. Na hora quando a gente começa a fazer vai lembrando. Faz tempo já. 
E: E aqui nessa distributiva, você fez -3 vezes $3 x$ deu $-9 x$.

A: É.

$\mathrm{E}: \mathrm{E}-3$ vezes 2 ?

A: Era pra dar menos.

E: Era pra dar menos. Esse sinal de menos aqui...

A: Por isso que tava dando errado.

E: Esse sinal de menos é da fração toda, então aqui esse sinal de menos vai pra todo mundo desse pedaço da segunda parte, tá? E quando a gente coloca sobre 15, por que a gente tem que por sobre 15 e não dá pra fazer a conta desse jeito que tava no começo? Você sabe?

A: Não sei.

E: Porque assim, pra gente poder somar ou subtrair frações, elas têm que ter o mesmo denominador, ter a mesma parte de baixo. Então não dá pra eu fazer essa conta com uma sendo 3 e outra sendo 5, então precisa ser todo mundo sobre 15. Por isso a gente tira o MMC, tá? Vamos lá. E esse daqui?

A: Esse daqui eu não consegui fazer, eu copiei.

E: Copiou? Confessa. (Risadas)

A: Eu não lembrava não.

E: Então, aqui, não sei de quem foi que você copiou, então vamos tentar entender. Você tirou o MMC, certo?

A: É.

E: Aí o MMC aqui, se eu tenho... esse já tá sobre 4, então não vai mudar nada. Esse daqui, pra eu colocar ele sobre 4, eu tenho que multiplicar a parte de cima por 4 também.

A: Entendi. 
E: Então tinha uma regrinha, que aqui era $x+1$ sobre 1, divide pelo de baixo e multiplica pelo de cima. Lembra disso?

\section{A: Lembro.}

E: Então o 4 dividido por 1 vai dar 4, vezes essa parte de cima fica 4 vezes isso tudo, e aqui continua. E aqui tem aquele mesmo problema que a gente tava conversando antes. Então você passou o 3 pro lado de lá, ele tava multiplicando e vai passar dividindo, mas continua sendo 3. Sempre troca a operação, não o sinal. Aí nesse caso aqui, é bem parecido com esse, vai ficar todo mundo sobre 2 , só que qual é o denominador desse 4 ?

\section{A: Seria 1.}

\section{E: Seria 1. Certo?}

\section{A: Certo.}

E: Então aqui você multiplicou por 2, dividiu por 1, ficou 2, 2 vezes o de cima. Aqui 2 dividido por 2 vai dar 1,1 vezes $x$. e 2 dividido por 1, vai dar 2 . Aí você tem que fazer 2 vezes o 4 em cima porque ele não tá sobre 2 , ele tá sobre 1 .

\section{A: Entendi.}

E: Tá? Então aqui você considerou, não sei se foi você que fez esse, né, mas você considerou como se todo mundo tivesse sobre 2 , que nem o da letra $\mathrm{E}$.

A: É porque a gente já tinha feito o 2 como se tivesse o 4 já.

E: Entendeu?

A: Entendi.

E: E a letra G?

A: Aqui você vai multiplicar tipo todos por todos, né?

E: "Aham".

A: Daí vai dar aqui e você vai ter que fazer o Bháskara. Daí pra descobrir os dois $x$ você faz um 
positivo e o outro negativo.

E: Isso. Certinho. E esse aqui por que o Bháskara tem quatro termos?

A: Esse aqui tipo, a gente tava... a gente tinha feito uma vez e deu errado, daí a gente tentou fazer de novo.

E: Então, porque o Bháskara vocês precisam achar o $a$, o $b$ e o $c$. Quem é o $a$, o $b$ e o $c$ com quatro termos?

A: Seria o 1 , o 3 e o 2 , né?

E: Não dá pra juntar ninguém aí?

A: É, daí acho que aí teria que fazer com o 2, né?

E: Teria que juntar, olha, o $x^{2}$ não tem mais ninguém com $x^{2}$ pra juntar.

A: Entendi.

E: O $3 x$, não tem mais ninguém com $x$ pra juntar, agora o $2-6$ dá pra fazer essa conta. Quando vai dar $2-6$ ?

A: Dá -4 .

E: -4 , então aqui ficaria -4 , e você usaria $o-4$ pra fazer a conta.

A: Entendi.

E: Certo?

A: Certo.

E: É isso então.

A: Tá ótimo. 


\section{Entrevista 06}

E: Então vamo lá, me explica o que é que foi que você fez aqui no primeiro exercício. Você lembra ainda?

A: Eu não lembro o que eu fiz.

E: Não lembra? De nada?

A: Não.

E: Então tenta olhar aí e lembrar.

A: Aqui eu multipliquei o 3 por $x$, aí eu multipliquei pelo 1, daí ficou $3 x+3$.

E: “Aham".

A: Daí ficou igual a $x-1$. Daqui eu tava tentando não me perder, daí a professora falou pra mim que tava errado, daí eu deixei quieto.

E: O que é que tava errado?

A: $\mathrm{O} 2 x=2$. Ela falou que tava errado essa resposta.

E: Por quê? O que você fez aqui da primeira pra segunda linha? Passou o $x$ pro lado de lá e o que aconteceu com ele?

A: E daí esse aqui ficou...

E: Por que é que virou $-x$ ?

A: Porque esse $x$ foi pro outro lado também.

E: E aí quando vai pro outro lado acontece o quê?

A: O sinal muda.

E: O sinal muda. E o 3 foi pro outro lado também?

A: Foi. 
E: E o que é que acontece com o 3 ?

A: O sinal muda também.

E: O sinal muda. O sinal mudou?

A: Não.

E: Não, por isso que a professora falou que tava errado, então aqui tinha que ser um -3 , tá?

A: Tá, tá certo.

E: Mas dava pra continuar aqui. Como que você continuaria? Se tivesse certa essa parte.

A: Eu voltaria o 2 pro outro lado.

E: O 2 pro outro lado? E como que ele ficaria? Ficaria...

A: Dividido.

E: Dividido? E aí não muda o sinal?

A: Mudaria também.

E: Mudaria também? Quando passa pro outro lado troca o sinal? Tá. E a letra B?

A: A letra B, deixa eu ver... aqui tava $3 x$, eu multipliquei também pra cá o $5 x+1$ também.

E: Mas aí não é multiplicação?

A: Isso.

E: Não é 5 vezes 1 ?

A: Exatamente. Daí ficou 5 vezes 1 ficou 6 e 5 vezes $x$ ficou $5 x$.

E: Quando você faz 5 vezes $1 \ldots$ imagina 5 vezes o 1 , é fazer o $1+1+1+1+1$.

A: É, era pra ter dado 5.

E: É, era pra dar 5. Porque na realidade você somou, você fez 5 mais 1. 
A: É.

E: Né?

A: Eu acho que foi isso também que eu errei aqui.

E: E aí se tivesse certa essa parte aqui? $\mathrm{E}-5 x$, quanto que daria? É $4 x$ mesmo?

A: É.

E: É? Imagina que você tem $1 x$ e você vai tirar 5 , você vai ter 4 ainda?

A: -4 .

$\mathrm{E}:-4$.

A: Verdade.

E: Certo? Na letra $\mathrm{C}$ vamos ver se você acha aí que tem alguma coisa errada.

A: Falta eu terminar aqui, né? Também.

E: Também. Mas antes tem um detalhe que você esqueceu olha, aqui esse 9, cadê ele na linha de baixo?

A: É verdade.

E: O que é que tinha que acontecer com ele?

A: Ele tinha que ter voltado.

E: Ele tinha que ter passado pro lado de cá. E o que ia acontecer com ele?

A: Ele ia mudar o sinal.

E: Mudar o sinal o sinal, aí ia ficar -9 e aí ia mudar a equação. Como você resolveria essa equação?

A: Essa equação?

$\mathrm{E}:-2 x=7$. 
A: Então, como eu tinha que passar pra esse lado, ele ia ficar negativo.

E: Ia. Quer tentar fazer? Tenta continuar aí.

A: Ia ficar 9-7.

E: Mas o 7 é resultado do $3+4.3+4$ vai dar -7 ?

A: Não. $7-9$ vai ficar -2 .

E: "Aham".

A: $x-2$, o 2 vai passar pra cá e ia dividir.

E: Dividir por 2 ou por -2 ?

A: Por -2 .

E: Mas quando passa pro outro lado não troca o sinal?

A: Troca o sinal, daí fica positivo.

E: Fica positivo? Então divide só por 2?

A: Pronto.

E: E aí isso ia dar quanto?

A: Ia dar 1.

E: Muito bem, então $x=1$. Certo?

A: Certinho.

E: Porque resolver a equação significa achar o valor do $x$, né? Então você achou o valor do $x$, acabou. Agora eu vou te contar um segredo: quando passa pro outro lado não troca o sinal.

A: Não?

E: Quando passa pro outro lado o que troca é a operação. 


\section{A: Só a operação?}

E: A operação. Então, por exemplo, quando você passa aqui o 9, ele tava somando, era alguma coisa mais 9. Quando eu passei pro lado de lá, eu passei subtraindo, aí dá a impressão de que troca o sinal. Esse $2 x$, ele tava subtraindo, então vai passar pro outro lado somando, aí dá a impressão de que troca o sinal. Entendeu? Então quando a gente muda de lado... aqui olha, era -3 , tava subtraindo, passa pra lá somando, trocou de operação. Parece que mudou de sinal, mas na realidade o que inverteu foi a operação. E aí quando a gente tem essa parte da multiplicação, se tá multiplicando eu vou passar pro outro lado dividindo, e aí o que vai trocar é a operação e não o sinal. Eu vou dividir por -2 .

A: Mas o sinal permanece?

E: Permanece, só vai trocar a operação. Aí se a operação for uma soma ou uma subtração aí vai trocar a operação e vai parecer que trocou o sinal. Tá?

A: Tá... entendi.

E: E na letra D? Me explica aí o que você fez.

A: Na letra D...

E: O que você fez com o 3 e o 5 que sumiu?

A: Fiz uma bagunça aqui, completamente.

E: Esse 3 e esse 5 aqui você ignorou, ou não? De onde surgiu esse $9 x$ ?

A: Esse $9 x \ldots$ eu multipliquei de $x$, assim.

E: Entendi. Aí ficou 3 vezes $3 x$, deu $9 x$. E aqui 3 vezes 2 que deu 6.

A: Isso.

E: Aí 5 vezes $2 x$ e 5 vezes 1 . E esse 2 aqui ficou sozinho. E aí?

A: Daí eu continuei. Daí esse aqui eu multipliquei, aí eu somei, né? 
E: "Aham".

A: Esse daqui também.

E: Mas aí ele tava desse lado, deu -1 e você passou pro outro lado.

A: Isso, pra completar.

E: Mas quando você resolve ele não continua do lado de cá?

\section{A: Continua.}

E: Então esse -1 tinha que estar do lado de cá junto com o 11. Se deu $-1 x$ e 11 do lado direito.
A: É... nossa.

E: Não é? Então tinha que ficar aqui... tinha que ficar aqui... coloca aqui embaixo: $-1 x+11$. Não é? Do lado direito. Porque aqui você juntou, deu $-1 x$ e aqui você juntou e deu 11. E do lado esquerdo continua o 2. E aí como você resolve o resto?

A: Esse daqui eu sei o que eu fiz aqui. Esse aqui, o 2, eu passei pra esse lado.

E: Então, mas aí ele tava multiplicando alguma coisa?

A: Não.

E: Então ele não passa dividindo, né?

A: É.

E: Como resolveria a partir daqui então?

A: A partir daqui... dividindo? Aqui eu já não sei.

E: Você tem que descobrir o valor do $x$, então passa o que tem $x$ pro lado de lá e o que não tem $x$, pro lado de cá.

A: Então seria o $-1 x$ que passaria pro outro lado.

E: Passaria pro outro lado. Ele tá subtraindo, passaria pro lado de lá somando. Então vai ficar 
$+1 x$. E você passou o 2 dividindo de novo, ele não tá multiplicando pra passar dividindo.

A: Verdade.

E: Ele tá somando, ele passa pra lá subtraindo. Então vai ficar $11-2$. Certo? E esse $-1 x$ que mudou pro lado de lá, o que vai acontecer? Era $-1 x$ vai passar $+1 x$ porque tava subtraindo e vai passar pra lá somando. Certo?

A: Certo!

E: Então essa baguncinha que você fez aqui teria que ser desse jeito.

A: É, e teria que ser totalmente ao contrário.

E: É, tudo bem?

A: Tá.

E: Vamos ver a parte de trás.

A: Nossa, aqui eu fiz uma bagunça.

E: Esses daí você lembrou a fórmula de Bháskara direitinho? Lembrou.

A: É, ficou meio bagunçado, mas...

E: E esse 6 aqui, você cortou do nada?

A: Deixa eu ver... olha, eu não entendi porque eu cortei.

E: Daqui pra cá você fez a distributiva, né? E vezes $x, x$ vezes 2 , só fazendo a distributiva.

A: Isso. Daí aqui ficou $+x$.

E: "Aham".

A: Não sei porque cortei o de cima.

E: Ele tava te atrapalhando aí você cortou.

A: É. 
E: Entendi. Na realidade o que você teria que fazer com ele é: passar pro lado de lá e juntar o que desse. Então o $2 x+1 x$ dava pra fazer a conta, dá $3 x$. E esse 6 ia passar pra cá e ia ficar $2-6$. E toda equação de segundo grau a gente deixa igual a 0 , e aí faz o Bháskara quando tá igual a 0 .

A: Então era pra ter primeiro resolvido aqui.

E: Primeiro arrumado, tá? E na letra E, o que você fez aí?

A: Deixa eu ver... aqui tá o 1 e eu passei pra esse lado.

E: Do enunciado pra sua primeira linha, o que você fez? Por que é que deu $-2 x$ ?

A: Porque eu acho que eu somei aqui.

E: Pode somar?

A: Não.

E: -2 ? Um tem $x$ e o outro não tem, né?

A: É.

E: Então não pode. Aqui o que você fez? Transformou essa subtração numa multiplicação, virou 2 vezes $x$ e era pra ser $x-2$.

A: É, verdade.

E: E aí o que você fez com esse 4 ?

A: Ele virou.

E: Ele virou aqui olha, tinha o +4 , apareceu. Então você passou o $2 x$ pro lado de lá.

A: Sim, aí eu virei pra esse lado.

E: E aí, o que mais? E cadê o valor do $x$ lá no final? Sumiu o igual.

A: É, era pra ter. Se eu fiz desse jeito que era errado, tinha que ter ficado assim... na verdade não assim, né? 
E: Tinha que ser $x$ igual a alguma coisa, certo?

\section{A: Certo.}

E: A mesma coisa aqui olha, sumiu o $x$. O que é que aconteceu? O que é esse 2 aqui que você anotou?

A: Eu acho que eu tinha dividido.

E: Dividiu por 2? Mas não mudou nada daqui pra cá.

A: É.

E: Será que você lembra o que você pensou aí?

A: Esse daqui eu passei pra cá e ficou $x$ e $x$, aí esse daqui eu passei pra cá e daí somou e ficou +5 .

E: Mas se ele tá somando, quando ele passa pra cá acontece o quê?

A: Muda o sinal.

E: Devia dar +5 então?

A: Não.

E: Ia ficar $4-1$, né? E ia dar quanto?

A: -3 , é 3 .

E: 3. E o que mais? Você somou o 2, mas o 2 era parte de baixo da fração e o 5 tava em cima. Então você somou os dois e deu 7 e esse é o valor do $x$ ?

A: Eu tinha feito isso. Eu não sei por que tinha dado $2 x$ aqui em cima. Aí depois sumiu.

E: Sumiu do nada? E aí aqui deu 7, sumiu o $x$, sumiu o igual, aqui já não tem igual também.

A: Verdade.

E: Tem que ter um igual, você vai passar as coisas de um lado pro outro. O que é uma equação? 
Você sabe me dizer?

\section{A: Equação?}

E: Isso tudo que você resolveu são equações. O que é uma equação?

\section{A: Não sei falar.}

E: Não? Esse sinal de igual aqui significa que uma coisa é igual à outra, então imagina como se fosse uma balança: quando as duas coisas estão iguais, a balança tá equilibrada, se você faz uma coisa de um lado da equação, você tem que fazer do outro lado também, se não ela desequilibra.

Então se você multiplicou por 2, vai multiplicar do outro lado também. Então todas as contas que você faz, você faz dos dois lados, então tem que manter o igual. Em algum lugar aqui dessa linha tinha que ter um igual.

A: Pra permanecer, né?

E: Pra permanecer sendo uma equação. Tá bom?

A: Tá bom.

E: Acho que é isso então.

\section{Entrevista 07}

E: Vamo lá, quero que você me explique o que você fez no primeiro exercício.

A: Primeiro eu fiz distributiva, depois eu passei o $x$ pra cá e mudei o sinal.

E: Por que é que muda o sinal?

A: Porque eu tô invertendo. Aí depois eu resolvo o 3, subtraio o x, aí eu somei aqui, né, subtrai. Aí depois eu passei o 2 que tava multiplicando pelo $x$ pra dividir o resultado .

E: E aí não passa invertendo o sinal?

A: Passa. 
E: Toda vez que muda de lado troca o sinal?

A: Sim.

E: Você não mudou o sinal aqui do 4, nem aqui do 2 pra passar dividindo. Vou te contar um segredo: não muda o sinal quando troca de lado, o que troca é a operação.

A: Entendi.

E: Então, por exemplo, quando você tá somando o 3 aqui, ele passa pra cá subtraindo, então dá essa impressão de que mudou o sinal, mas o que tá invertendo é a operação.

A: "Aham".

E: Quando você tá multiplicando, ele passa dividindo, então não muda sinal nenhum. Esse aí tá certinho.

A: Tá.

E: Fiz a pergunta só pra te confundir e você caiu.

A: Muita pressão.

E: Aí esses outros dois eram parecidos. E a letra D?

A: Na letra D primeiro eu fiz o MMC, aí já deu 15, aí depois que a gente multiplica a gente já divide, né? Aí deu 1.

E: E esse menos aqui, era o menos da fração toda, não era?

A: Sim.

E: Por que é que ele ficou só pro 9?

A: Porque eu igualei aqui.

E: Então, mas o menos era pra todo mundo.

A: Sim. 
E: Então o que tava aqui, o 9 que você multiplicou por 3 tinha que ter o menos e o 2 que você multiplicou por 3 também tinha que ter o menos.

A: Tinha que ser -6 .

E: Tinha que ser -6 . E nesse daqui você tirou o MMC também? Você fez o quê? Aqui você passou o 4 multiplicando, certo?

A: Sim.

E: Só que ele vai passar pro outro lado multiplicando tudo. Então na realidade aqui você multiplicou só o $x$, e o 1 você não multiplicou, e teria que multiplicar tudo.

A: Tá.

E: E nesse daqui você passou o 2 pro lado de lá multiplicando?

A: Sim.

E: E esse 4 aqui? Qual a diferença da letra E pra letra F?

A: Que aqui tá dividindo, né, e aqui tá somando.

E: É que o $x-2$ todo tava sobre 4 e aqui o 4 não tá sobre 2, então ele é sobre 1.

A: Sim.

E: Que você mesmo colocou, certo? Então eu teria que tirar o MMC aqui pra ficar todo mundo sobre 2 e aí sim passar o 2 pro outro lado multiplicando.

A: Tá.

E: Os outros dois tão certos.

A: É tudo desatenção... Eu quase não pratico.

E: Agora você vai praticar mais. Obrigada, viu. 


\section{Entrevista 08}

E: Então vamo lá, me explica o que você fez na letra A.

A: É que você explicou, aí bateu a lembrança.

E: Certo. Aí eu expliquei que tinha que multiplicar.

A: É, aí eu lembrei mais ou menos como fazia, mas fiquei na dúvida. Geralmente as questões de Matemática têm que ter um exemplo pra eu poder seguir.

E: Entendi.

A: Aí conforme eu vou fazendo, aí eu entendo. Só que quando não dão um exemplo eu não consigo fazer, aí bate um bloqueio.

E: E se o exemplo não tem nada a ver com o que você vai fazer você não consegue?

A: Não consigo.

E: Se for muito diferente.

A: Não, tenho um bloqueio. Sempre aconteceu isso.

E: Tá bom, então só tenta me explicar aí o que você fez na letra A.

A: Tinha que multiplicar, aí 3 vezes $x$ eu deixei $3 x ; 3$ vezes 1 , 3 . Ai como tinha sinal eu mantive, aí depois eu coloquei o sinal de igual e copiei, aí depois eu fui resolvendo embaixo.

E: Entendi. Então daqui pra cá, aí você passou o $x$ pro lado de lá.

A: É que eu sei que tem passar o $x$ pra um lado e número pro outro.

E: E quando muda de lado não acontece nada?

A: Aí muda o sinal.

E: Aí você esqueceu desse detalhe, né? Porque era $+x$ e continuou $+x$ e o +3 continuou +3 .

A: Eu sempre tive problema com sinal, sempre me confundo. Eu sempre tenho anotado, toda vez 
que o professor passa lição ou matéria nova, enquanto ela tá explicando eu vou fazendo anotação porque se não eu me perco, em qualquer matéria.

E: Entendi.

A: O que vai número e conta eu acabo me perdendo, eu tenho que fazer anotação. Mesmo em Português que eu vou melhor, eu faço anotação.

E: Entendi. E aqui na próxima linha sumiu o igual.

A: Ai que medo.

E: O que aconteceu com ele?

A: Às vezes eu esqueço. É que nem redação, às vezes eu esqueço das coisas.

E: Então aqui $3 x+x$ deu $4 x$, e 3-1 deu 2, então aqui devia ter um igual, né?

A: É.

E: Que é o igual que tá aqui. E aí $4 x-2$, eu posso fazer essa conta?

A: Pode.

E: Pode? Um tem $x$ e o outro não tem.

A: Verdade, não pode.

E: Não pode, senão daria pra juntar esse aqui também.

A: Aí eu teria que colocar $x=4-2$.

E: Isso. Você tem que achar o valor do $x$ e você fez isso nas três primeiras, e em nenhuma delas você disse que o $x$ é igual a alguma coisa. Todas elas você sumiu com o igual, sumiu com o igual e sumiu com o igual.

A: Esse é o problema pra mim quando eu faço alguma coisa tem que ter um exemplo de Matemática, pra mim poder seguir, pra mim poder acertar. Mas eu acho que eu melhorei um pouco em Matemática. Então minhas notas sempre foram ruins em Matemática, tanto que eu 
tenho dificuldade em Física porque tem que fazer conta.

E: Então você gosta só de ler.

A: É, eu leio muito.

E: Eu leio muito pouco.

A: Eu prefiro ler do que fazer conta.

E: Eu prefiro fazer conta do que ler.

A: Minha mãe incentiva bastante a ler.

E: Vamo lá, a letra D.

A: A letra D também foi uma confusão.

E: Por que você colocou todo mundo sobre 15 ?

A: Porque você tinha falado que precisa tirar o MMC, aí como eu fiz o MMC, deu 15, mas eu tinha ficado em dúvida se tinha que tirar o 15 e colocar como fração ou não.

E: Tá. Aí por que mudou o número de cima?

A: Aí ficou tudo muito confuso.

E: Por que aqui o $2 x$ virou $10 x$ ?

A: Porque eu multipliquei.

E: Por quanto?

A: Por 5. E esse aqui por 3.

E: Por quê?

A: Porque você tinha falado do MMC.

E: E aí o que aconteceu pra próxima linha? 
A: Aí que... eu consegui fazer essa metade certinho, aí depois...

E: Não disse que tá errado, quero saber o que que aconteceu aí. Por que que ficou 15 sobre 2 ?

A: É que eu tava em dúvida como ficava embaixo, se não tinha que ter uma conta, aí acabou ficando assim. Aí como eu fiz a conta na calculadora, deu 7,5.

E: Você esqueceu de me dizer de onde veio o 15 sobre 2. O resto tudo você esqueceu? Só sobrou o 15 e o 2 ?

A: É, então, por causa disso. Eu não sabia da onde vinha, aí eu acabei fazendo desse jeito.

E: Aí você inventou alguma coisa pra ter uma resposta?

A: Não é que eu inventei, é que eu ia deixar só a primeira, aí eu me foquei na de baixo, aí não dá certo. Eu me dou melhor nas outras matérias e meu irmão caçula faz conta de cabeça.

E: Entendi.

A: E eu já não.

E: Então a Matemática ficou com ele.

A: A Matemática ficou com ele e Português, Geografia e até História eu me dou bem. Agora, Matemática ficou com ele.

E: E aqui na letra E?

A: Foi o mesmo problema da letra A, que eu não consegui chegar no valor de $x$.

E: "Aham".

A: Aí você falou... só que embaixo assim, eu esqueci.

E: Sumiu o igual e esqueceu do valor do $x$.

A: Sumiu o igual.

E: E aqui? Por que ficou 4 vezes isso tudo? 
A: Porque você falou que precisava dividir a fração e tinha que passar pra cá, aí eu fiz. Aí eu coloquei entre parênteses o $x+1$, aí coloquei o igual e coloquei o resto da fração do outro lado.

E: Muito bom.

\section{Entrevista 09}

E: Vamo lá então. Me explica o que é que você fez no primeiro.

A: Então, no começo eu não lembrava né, aí quando começou a explicar, fui respondendo. Aí eu ia fazer direto. Sei lá como que eu ia fazer, mas eu ia fazer direto, do jeito que eu inventei na minha cabeça.

E: Do jeito que você inventou na sua cabeça?

A: Aí você explicou que eu tinha que fazer esse por esse e por esse, aí eu fui lembrando.

E: Aí você lembrou.

A: Aí fui lembrando de tudo.

E: Tá, aqui você multiplicou e o que você fez aqui pra segunda linha?

A: Aí eu multipliquei, aí esse aqui eu deixei do mesmo jeito, né, porque não tinha nada pra fazer. Aí aqui eu fiz a multiplicação desse e esse e aqui eu fui passando as letras pra esse lado, os números pra esse.

E: Por que é que ficou $-x$ ?

A: Porque aqui ele era mais.

E: E o que acontece quando passa de lado?

A: Aí ele fica negativo. Quando é daqui pra cá, mas quando é de lá pra cá fica a mesma coisa, né?

E: Fica a mesma coisa? Esse 3 aqui ficou -3 .

A: Sei lá. 
E: Foi você que fez, só tô tentando entender o que é.

A: Eu acho que é. Enfim, aí aqui eu fui diminuindo e esse negócio que não tem nada é 1 e aqui também. Aí eu fiz a conta.

E: E esse 2 aqui que passou daqui pra cá, ele troca o sinal?

A: Acho que aqui não.

E: Não? Por que não?

A: Não sei, quando a professora me ensinou, ela que ensinou que tipo, aqui era só pra multiplicar sabe... só pra multiplicar não, só pra dividir, então não precisava, eu acho, mudar o sinal.

E: Tá, entendi. E nesse daqui? Na letra B.

A: Aqui eu só copiei, aí aqui eu separei e fui multiplicando. Fiz a mesma coisa, aí eu só fui separando as letras dos números.

E: Você passou o 5 pra lá e trocou o sinal do 5 , e o 3 pra cá e não trocou?

A: Verdade.

E: Porque só troca quando passa pra lá, pelo que você falou.

A: "Aham".

E: E aí $x-5 x$ deu $4 x$ por quê?

A: Era pra ter dado -4 .

E: Era pra ter dado -4 ?

A: "Aham".

E: E aí você passou o 4 dividindo. Por que é que ele passa dividindo?

A: Não sei, porque é sempre dividindo. Não é?

E: Sempre? Aqui esse -3 não passou pra lá dividindo. 
A: Não, eu só divido quando chega aqui.

E: Só no último passo então?

A: É.

E: Entendi. E na letra C?

A: Aqui como não tinha esse negócio eu fui só separando as letras dos números, aqui eu só somei porque eu fiz o resultado.

E: Aqui você passou o 4 pra lá. Esse 4 aqui ele era menos, ele não mudou de lado e não era pra continuar menos?

A: Verdade.

E: Devia ter um menos aí, né?

A: "Aham".

E: Tá, então continua. O que mais?

A: Aí eu fui somando, aí essa eu dividi também. Mas eu acho que essa deu errado mesmo porque eu falei assim “como que é um número desses?”.

E: Pode ser esse número.

A: Pode?

E: Pode. E na letra D?

A: Essa daqui eu não lembrava como fazia, só lembrava que... eu falei assim "Não, eu acho que tem que fazer o MMC porque sempre quando tem número embaixo e em cima nas contas tem que fazer o MMC".

E: "Aham".

A: Aí você falou que tinha, aí eu fiz.

E: E aí em cima não muda nada? 
A: Não porque primeiro você resolve o MMC, aí você só copia, aí você falou que corta esse número e aí você resolve.

E: Entendi. Então eu poderia não ter feito o MMC e ter cortado o 3 e o 5, é isso? Porque ficou igualzinho.

A: É, eu também imaginei assim, né, mas tem que fazer, tem que cortar.

E: Entendi. E aqui, quando você fez 1 dividido por 1, vai dar 0 ? 1 dividido por -1 ?

A: Dá, não dá? Porque você tá devendo - 1 . Sei lá.

E: Tá bom. E nesse daqui?

A: Aí eu perguntei se quando não tinha nada colocava o 1 antes e você falou que sim. Aí eu fiz o MMC de novo.

E: Aí não mudou nada em cima. E aqui tem dois iguais.

A: É verdade.

E: Qual que é o igual que vale de verdade?

A: É porque tem aqui sabe, aí eu falei assim “Acho que é também, né?”. Aí eu coloquei.

E: Entendi. E aí $x-x$, você tem 1 e tá devendo 1 .

A: Fica só $x$.

E: Fica só $x$ ? Você não acabou de me dizer aqui que você tem 1 e tá devendo 1 é 0 ?

A: Mas é número.

E: E aqui você tem $1 x$ e tá devendo $1 x$.

A: Não sei o que eu fiz.

E: Aí ficou só $x$ ?

A: É. 
E: Tá, e na letra F.

A: Esse daí como também não tinha número você tinha que colocar o 1 e fazer o MMC, cortar. Quase a mesma coisa, foi fácil. Tá certo? Não sei se tá certo.

E: Não sei, aqui tem dois iguais de novo, olha.

A: É porque tipo, aqui tem sabe, aí eu coloquei, mas eu acho que é um sinal de vezes. Não, porque aqui não fica igual, aí tem que separar, não é? Então como eu tirei esse aqui, aqui eu vou separar. Aí tem que ter o igual pra mim saber o lado de cada um.

E: Entendi. E na letra G?

A: Essa aqui eu não terminei, não deu tempo.

E: Mas o que é que você fez até aí?

A: Você falou também que tinha que fazer esse por esse, por esse, por esse. Aí eu fiz, aí aqui eu tinha errado, $x^{2}-1$. Eu só cheguei a fazer...

E: Só a distributiva.

A: É.

E: E depois disso aí, você faria o quê? Se desse tempo.

A: Aí eu ia separar, né?

E: Letra pra um lado.

A: E números pro outro.

E: Quer tentar fazer agora?

A: Não, não precisa não.

E: Tenta aqui embaixo.

A: Esse $x^{2}$ ele também conta, né? 


\section{E: Lógico.}

A: Você vai me confundir.

E: Eu não vou te confundir, não tô falando nada.
A: Tá sim.

E: Como eu vou te confundir sem falar nada?

A: Porque você ficou assim.

E: Só por que eu tô olhando você fazer?

A: Aí agora aqui tá negativo, eu vou passar positivo sei lá por que, mas eu vou.

E: Sei lá por que é ótimo.

A: Eu não lembro como é o $x^{2}$, ele fica $1-1 x^{2}$ ?

E: Não sei.

A: Ai como você é chata, não tem ninguém vendo.

E: Mas eu quero saber como você faria. Se eu te contar perde a graça.

A: Porque quando não tem aquele fica 1 também? Eu não sei, eu não sei se vai ficar $x^{3}$, tem $x^{3}$ ?

E: Existe.

A: Mas eu vou colocar, né? Aqui fica 6, aí fica $x$ igual à 6. Eu não sei o que eu faço com esse 3, então vai ficar assim, tá?

E: Tá bom.

A: Só isso?

E: Só isso. Obrigada então.

A: Eu errei tudo, eu sei. 
E: Não sei.

\section{Entrevista 10}

E: Como não sabe nada? Vamo lá, você olha o que você fez e me conta o que é que foi que você fez.

A: Nem lembro direito, não tem como explicar.

E: Lógico que tem. O que é que você pensou pra chegar nisso daqui?

A: Tipo eu tinha que voltar pro passado pra fazer esse negócio. Não sei como explica, como é que eu posso falar

E: Fala do jeito que você quiser, não precisa falar matematicamente correto.

A: Não sei como explicar. Sei lá, eu fiz tipo... quando eu olhei eu fui lembrando da professora do $1^{\circ}$ ano e já fui fazendo. Fui igual um Chico Xavier.

E: O que é que significa esse 3 aí na frente do parênteses?

A: Não lembro.

E: Não lembra de nada? Foi você que fez mesmo?

A: Foi, mas fiz junto, né?

E: Você lembra de algum? Tem um monte aqui. Algum deles você lembra? E esse da fração, você lembra? Por que ficou todo mundo sobre 15 ?

A: A professora me explicou na hora. Ela falou pra mim o que tinha que fazer. Tinha que...

E: Não precisa ficar nervoso.

A: Eu lembro que você me explicou uma hora que precisava juntar todos... tipo, pegar assim na... pra dar um certo valor. Esse outro dar um certo valor, mas os outros tinham que dar um mesmo... tipo uma conexão. Aí eu fui tendo tipo um flashback. 
E: Como que o $2 x$ deu $10 x$ ? Como que isso aconteceu?

A: Na hora você lembra, na hora de explicar a gente esquece.

E: Mas faz só uma semana que você fez.

A: Não, mas não é que eu esqueci, é que na hora dá nervoso e eu esqueço.

E: Nervoso por quê? Eu estou só conversando, não tem problema em falar coisa errada. Só quero saber o que você fez, não estou dizendo nem se tá errado. E o 15 sobre 2? Por que deu 15 sobre 2? Você sabe?

A: Que eu me lembre, não sei se tá errado.

E: Sem problemas, pode falar.

A: Eu lembro que tem que dar um certo valor, mas sempre diferente. Depois que a gente fundir os dois, ter a resposta dos dois é pra dar a resposta.

E: Aí então você junta o $10 x$ com o 5 ?

A: Isso.

E: E o $9 x$ com o 6 ?

A: Isso. O que eu consegui foi o 7.5.

E: Mas por que deu 15 sobre 2, então? Eu não entendi.

A: Porque os dois deram 15, aí você faz o negócio e era 2. Aí eu coloquei e fica o 15 sobre 2.

E: Entendi. Aí o 15 dividido por 2 você foi lá na calculadora e deu 7,5?

A: É. É, agora eu lembrei que tem que fazer o MMC.

E: Essa parte você não gosta muito.

A: Não, não é que eu não gosto. Não é difícil, mas é que tem que fazer tabelinha. Mas aí eu lembrei, lembrei que tinha que fazer o MMC certinho pra dar certo o valor. 
E: Tá, agora me conta uma coisa: o que é resolver uma equação? O que significa resolver uma equação?

A: É, uma equação é um problema, né?

E: Resolver essa equação é determinar o quê?

A: O valor.

E: O valor do quê?

A: O valor da... eu esqueci agora, é o valor da...

E: É o valor do $x$, não é?

A: É, o valor do $x$.

E: Em nenhuma delas você me disse qual é o valor do $x$. Inclusive, em todas elas o sinal desapareceu. Cadê o igual aqui? Eu tinha o igual na primeira e na segunda linha, e depois? Cadê o igual?

A: É, nesse eu não fiz. Nenhum deles têm.

E: Nenhum resultado final tem. Ia ser algo como $x=2$ ou $x=1$, né? Sumiu o igual aí. Por que será que sumiu o igual? Não lembra? Mas você tem uma memória bem ruim. Uma semana e você já esqueceu tudo.

A: Eu tenho uma memória ruim só pra Matemática.

E: Só com Matemática? Só gosta de letras.

A: Vou falar uma brincadeira que falaram pra mim uma vez: eu sou bom em Matemática até a hora que as letras se misturam com os números.

E: Apareceu letra e já era?

A: Nossa.

E: Então você era bom em Matemática até a $5^{\mathrm{a}}$ serie? 
A: Eu me perdia bastante na $7^{\mathrm{a}}$. E a gente ainda ficou sem aula de Matemática o ano inteiro porque não tinha professor. Aí depois o professor que entrou era chato e todo mundo já tava perdido. Então eu tenho um trauma com a Matemática.

E: Entendi... bom, muito obrigada.

\section{Entrevista 11}

E: Me explica o que você fez na letra A.

A: Distributiva.

E: Certo.

A: Aí 3 vezes $x, 3 x$ e 3 vezes 1, 3. Certo? Sinal de mais dá mais.

E: "Aham".

A: Aí igual a $x-1$. Aí o $x$ que tá positivo vai passar pra lá negativo e vou separar letra de sinal, é... letra de número.

E: "Aham".

A: Aí fica $3 x-x=-1$ e eu passei o outro pra lá.

E: Já achou o problema já.

A: Nossa, verdade.

E: Errinho bobo, podia ter acertado essa.

A: Verdade.

E: Tá, então se fosse -3 aqui daria quanto desse lado?

A: Aí ia ser -4 . Ia ser $2 x=4$ e ia dar 2

E: Ia dar 2, certo? 
A: "Aham".

E: E nesse daqui?

A: Mesma coisa. Aí faz a distributiva aqui, aí dá $5 x$, aí 5 vezes 1 dá 5 , certo?

E: Certo.

A: Aí eu separei letra de número, dá $5 x$ e aqui tá positivo e vai pra lá negativo e fica $5 x-x$. Aí tem que dar positivo, tá -3 e vai passar pra cá, vai ficar positivo.

E: Mas você passou todo mundo pra lá.

A: Não.

E: Você passou o $5 x$, passou pra cá, ele já tava aqui, aí você passou pra lá. Eles deveriam estar do lado direito.

A: Não, mas não tem problema, tem?

E: Lógico que tem. Se você passou ele pra cá, quem devia estar negativo era o $5 x$ e positivo o x. Aí ficaria $-5 x+x$, ia dar $-4 x$.

A: Isso. Deu errado?

E: É, o sinal ficou diferente.

A: Era $-2 ?$

E: Era -2 . Então nesse caso aqui, você passou pra esse lado aqui, o $5 x$ já tava do lado direito e você passou o $x$ pro lado direito, então eles tinham, na próxima linha, que estar os dois no lado direito. E aqui, o 3 e o 5 você também passou pro lado direito. Então ou você coloca todos eles do lado direito, ou alguém você passa pro lado esquerdo, ou o $x$ ou os números.

\section{A: Entendi.}

E: Tá? E quando você passa de um lado pro outro, o que é que acontece?

A: Como assim de um lado pro outro? 
E: Quando você passa $\mathrm{o}-3$ pro lado de lá, o que acontece?

\section{A: Positivo.}

E: Ele troca de sinal? Sempre?

A: É.

E: Por exemplo, esse 4 daqui você passou pra lá dividindo.

A: Não, mas tava multiplicando.

E: E por que é que quando passa não troca de sinal?

A: Não, mas é porque a regra é que quando tá multiplicando passa pra lá dividindo, e não passa pra lá dividindo negativo, entendeu?

E: Tá, mas esse -3 quando passa pra lá não troca o sinal?

A: Sim.

E: E aqui não troca?

A: Trocaria? Não tem que trocar.

E: Não.

A: É uma regra, não é?

E: Porque na realidade o que troca é a operação. Então esse -3 ele tá subtraindo, quando a gente passa ele pra lá, ele passa somando. E aí dá a impressão de que ele trocou de sinal. Aqui o 4 tá multiplicando, ele passa pra lá dividindo, mas continua sendo 4 . Se ele fosse -4 aqui, passaria dividindo por -4 . Tá? E nesse daqui?

A: Eu sou burro.

E: Você não é burro.

A: Tá vai, 9... não acredito que eu errei isso. 
E: O que você errou?

A: Não, aqui. Eu separei letra de número, aí o -2 tá aqui e passei o -4 pra lá e ficou positivo, certo?

E: Certo.

A: Se era positivo passou pra lá negativo e o 4 que era positivo passou pra lá negativo, aí eu somei aqui, fica $9-7=2 x$ porque $4 x$ mais $-2 x$ é igual a $2 x$. Esse tá certo, né?

E: Esse tá.

A: Aí esse aqui eu fiz o MMC.

E: Por que é que tem que fazer o MMC?

A: Porque tem dois números no...

E: Denominador.

A: É.

E: Dois números diferentes. E se fosse 3 e 3, teria que fazer o MMC?

A: Sim.

E: Também?

A: É, eu faço sempre, não interessa o número.

E: Mas por quê? Você faz porque disseram que tem que fazer?

A: Não, eu faço porque eu aprendi assim, tipo, quando não tem nada é 1, é meio que visível assim, eu bato o olho e vejo que tem que fazer o MMC.

E: Entendi. Porque, na realidade, quando a gente vai comparar ou somar frações ou subtrair no caso, todas elas têm que ter o mesmo denominador. Então o MMC o que você fez, na realidade, foi escrever todo mundo com o denominador 15. Então pra esse 3 virar um 15 você tem que multiplicar por 5 , então você multiplicou a parte de cima por 5 também, né? Como que você 
chegou nesse $10 x+5$ ? Que conta que você fez?

A: 15 divide pelo de baixo e multiplica pelo de cima.

E: Multiplica pelo de cima, certo? E agora uma pergunta, esse sinal de menos aqui é um sinal de menos pra fração toda, então ele é um sinal de menos pro $3 x$ e é um sinal de menos pro 2 também. Certo? É o menos da fração inteira.

A: É.

E: Então quando você faz essa conta aqui, o que acontece com esse sinal de menos? Ele fica só pro $9 x$ ? Entendeu minha pergunta? Esse sinal de menos é o sinal de menos da fração toda, o $3 x$ e o 2 estão em cima da fração, no próximo passo o $3 x$ virou $9 x$, tem o sinal de menos no 9x, e o 2 virou 6, e devia ter o sinal de menos no 6 também.

\section{A: Tá errado?}

E: Tá errado, esse daqui devia ser um sinal de menos porque esse sinal de menos é da fração inteira. Entendeu?

A: Entendi.

E: Então tem que ter o -9 e o -6 também. O resto tá certo.

A: O resultado tá errado?

E: O resultado tá errado. Ele vai dar 31, o resultado final. Vamo lá, a letra E, o que é que você fez aí?

A: Me deixa lembrar, tá? $x+1=x-\ldots$ aí eu peguei e fiz... tipo não tem nada, aí eu peguei e pus o 1. Certo?

E: Certo.

A: Aí eu peguei e tipo, o MMC é 4.

E: "Aham". 
A: Aí eu dividi tipo, pelo de baixo e multipliquei pelo de cima. Aí dá isso aqui.

E: Certinho.

A: Aí $4 x-x$, porque esse aqui tá positivo e vai passar pra lá negativo.

E: “Aham".

A: E eu separei letra de número e o que tá positivo vai passar pra lá negativo. Não sei por que não passou.

E: De novo não passou.

A: Nossa meu.

E: Pronto, já achou seu erro, pode passar pra letra F.

A: Sabe o que é que é? É não rever.

E: Tá vendo, quando você faz assim explicando pra alguém você estuda mais, se você pegar às vezes e estudar com um amigo...

A: Não, mas é na pressa assim, você tem o tempo certinho.

E: Aí não deu tempo de rever. Mas eu tô falando pra estudar até pro vestibular e tudo mais, que tá aí quase chegando já, né. Se você estudar com alguém, explicando pra alguém, você aprende mais. Se você souber a ponto de saber explicar, quer dizer que você entendeu de verdade. A letra F.

A: Aí não tem nada, passei o 2, 1, certo?

E: Certo.

A: Aí o MMC é 2. Aí eu dividi pelo de baixo e multipliquei pelo de cima, a mesma coisa. Aí $2 x+x \ldots$ tá certo isso aqui?

E: Tá certo.

A: Tá, aí esse $x$ tá positivo e eu passei pra lá negativo, $-x$, aí o 2 tá positivo e passei pra lá 
negativo. Acertei um.

E: Isso, e aí a letra G.

A: Aí é a distributiva, aí $x$ vezes $x$ é $x^{2}, x$ vezes 1 é $x$ e mais com mais, dá mais. Certo?

E: Certo.

A: Aí -3 vezes $x$ dá $-3 x$. Aí -3 vezes 1 e menos com mais é menos, 3 vezes 1 é 3 , daí dá -3 igual a 0 .

E: Isso.

A: Aí eu juntei esses aqui e ficou $2 x$. Aí ficou $x^{2}+2 x-3=0$.

$\mathrm{E}:+2 x$ ? É $1 x-3 x$. Quanto dá?

A: Dá $-2 x ?$

$\mathrm{E}:-2 x$

A: Nossa, eu errei tudo, de novo.

E: Não, na verdade aqui quando você vai fazer ao quadrado não vai fazer diferença, o delta deu certo e aí só no final que o sinal ficou errado.

A: E tipo, não é o resultado $x_{A}$ e o $x_{B}$ não é esse?

E: Não, não é esse. E por que é que deu 1 nos dois casos aqui? A fórmula de Bháskara era essa, certo?

A: Não, eu vacilei. Já até vi.

E: Já até viu? O que você fez?

A: Não, ridículo isso. Olha isso: 6 dividido por 2.

E: É, pois é.

A: Tá, vamo pular. 
E: (Risadas) Tá, letra H.

A: Essa aqui eu acertei?

E: Não sei. Me explica aí, vamos ver se você acha algum problema.

A: $x^{2}+2 x$. Nossa Senhora, não acredito!

E: O quê?

A: Não, tipo, isso tudo. Tá, aí eu fiz a distributiva e tal e esse aqui deu certo. Deu?

E: Deu.

A: Aí $2 x \operatorname{com} x$ dá $3 x$ aí mais 2 igual à 6 . Aí $x^{2}+3 x$, aí o 6 tá positivo e vai passar pra lá negativo. Aí vai ficar $\ldots-4=0$. Aí eu fiz a fórmula, tipo, $b^{2}$ que é 3 . Tem $a, b$ e $c$. E -4 vezes 1, que quando não tem nada é 1, quer dizer, 4. Aí deu isso aqui e isso aqui. Esse aqui eu acertei, eu acho, né?

E: Certo?

A: Tá bom. Nossa que lixo!

E: Mas você errou tudo a mesma coisa, que foi falta de atenção.

A: É.

E: Só passou pra lá e esqueceu de trocar o sinal. Tá bom?

A: Tá bom.

E: Tá aí o seu feedback.

A: Obrigado.

\section{Entrevista 12}

E: Então vamos lá, me conta o que você fez aqui na letra A. Você lembra? 
A: Eu fiz esse vezes esse, 3 vezes o $x$ e 3 vezes 1, aí igual e copiei. Aí eu coloquei letra pra um lado e números pro outro, aí eu somei, mas no caso aqui eu subtraí, aqui também. Aí deu esse resultado, aí eu coloquei o x pra cá.

E: Por que é que o $x$ quando passou pra cá ficou $-x$ ?

A: Porque quando ele depois, antes do igual e vai pro outro lado do igual, ele vai como negativo. Se ele fosse negativo aqui, ele ia como positivo.

E: Tá.

A: Aí aqui eu coloquei o $x$ e dividi.

E: E aí 2 dividido por 4 deu 2? Se eu tiver 2 coisas e dividir por 4, cada um vai ficar com 2 ?

A: Ah, era pra ser 4 dividido por 2 !

E: Era pra ser 4 dividido por 2. Tá? Letra B.

A: O $x$, como ele não tem nada, ele tem o 1 na frente.

E: "Aham".

A: E a gente tem que fazer primeiro o que tá entre parênteses. Aí aqui eu fiz, resolvi 5 vezes $x$ e 5 vezes 1 .

E: "Aham".

A: Aqui eu subtraí, aqui também. E eu não sei o que fiz aqui. Aí foi o mesmo caso, coloquei o $x$, esse aqui fica aqui e esse divide pelo de baixo.

E: E quando passa esse - 4 dividindo ele não troca de sinal? Ele passou pro outro lado do igual.

A: Então aí tem que fazer vezes -1 e aí ele vai dar o número.

E: Quando tá no negativo?

A: Sim.

E: Entendi. E na letra C? 
A: Na letra $\mathrm{C}$ eu copiei aqui, eu copiei o que tava aqui, aí aqui eu coloquei as letras de um lado, os números de outro e resolvi.

E: Tá, e a letra D?

A: Aqui eu resolvi.

E: Resolver aqui significa fazer o quê?

A: $3 x+1$.

E: Dá pra juntar $2 x$ com 1 ?

A: Dá.

E: Por que é que você não juntou aqui, $5 x+5$ não deu $10 x$.

A: É verdade.

E: Não dá pra juntar quando tem $x$ e quando tem número. E esse daqui? Essa conta que você fez aqui.

A: Eu tirei o MMC de 3 e 5.

E: Por quê?

A: Porque quando tem número em fração tem que fazer o MMC.

E: Sempre?

A: Sim.

E: E nesses últimos aí? Na letra G.

A: A mesma coisa. Aqui quando não tem nada é 1-6, aí aqui mesma coisa igual a zero. Coloquei as letras de um lado, os números pro outro.

E: E os parênteses? Eles servem pra quê?

A: Pra separar. 
E: Só separar? O que é que tem entre um parêntese e outro?

A: Um vezes?

E: É um vezes. E como que você faz essa conta de vezes?

A: Seria aqui, né?

E: Você não fez a conta de vezes né. Como será que teria que fazer?

A: Teria que fazer... não sei. Seria esse vezes esse e esse vezes esse?

E: Isso. Quer tentar fazer? Vamo tentar fazer aqui embaixo.

A: Aí vou fazer o $3 x$ vezes o $x$, vezes o $x$ ou não? Não, né?

E: Não sei, você que tá fazendo, tô só olhando.

A: Não sei. Aí eu ia fazer 1 vezes 1 de novo. Aqui eu ia fazer o 3 vezes o $x$ que ia dar $3 x$.

E: E o que você faz com todos esses números?

A: Aí aqui a gente vai colocar $1 x$. Agora não sei. Sem me confundir.

E: Eu não fiz nada.

A: É, eu esqueci como fazer. Não sei.

E: Não sabe? Então deixa, não tem problema. E nesse aqui da letra $\mathrm{H}$.

A: Nesse daqui também tá tudo certo, que eu não coloquei o vezes. Fiz a mesma coisa.

E: E esses dois aqui que ficaram em branco? O que é que aconteceu?

A: Eu não sabia fazer. Eu já tinha me confundido muito com esse que tinha 2.

E: Que tinha fração.

A: Aí quando chegou aqui só tinha uma fração, aí eu fiquei muito na dúvida.

E: Mas tinha menos fração, você ficou mais na dúvida? 
A: É por causa que quando tem, eu achava que quando tinha duas assim dava pra tirar o MMC e você ia descobrir o valor.

E: Entendi. E nesse daqui se eu colocar o $x+1$ ele estaria sobre quanto, se não tá nada escrito? Quando não tem nada escrito é o quê?

A: Zero?

E: Sobre 1. Então fica $x+1$ sobre 1, aí daria pra tirar o MMC também.

A: Eu não lembrava.

E: Mas você não lembrava disso. Então tá bom.

A: Tá bom?

E: Muito obrigada.

A: De nada. 